University of Louisville

ThinkIR: The University of Louisville's Institutional Repository

Electronic Theses and Dissertations

$12-2010$

\title{
Testing the use of molluscs to infer climate with special reference to the late Cenozoic molluscs of the Meade Basin, southwest Kansas.
}

Brian William Steffen 1975-

University of Louisville

Follow this and additional works at: https://ir.library.louisville.edu/etd

\section{Recommended Citation}

Steffen, Brian William 1975-, "Testing the use of molluscs to infer climate with special reference to the late Cenozoic molluscs of the Meade Basin, southwest Kansas." (2010). Electronic Theses and Dissertations. Paper 1376.

https://doi.org/10.18297/etd/1376

This Doctoral Dissertation is brought to you for free and open access by ThinkIR: The University of Louisville's Institutional Repository. It has been accepted for inclusion in Electronic Theses and Dissertations by an authorized administrator of ThinkIR: The University of Louisville's Institutional Repository. This title appears here courtesy of the author, who has retained all other copyrights. For more information, please contact thinkir@louisville.edu. 
TESTING THE USE OF MOLLUSCS TO INFER CLIMATE WITH SPECIAL REFERENCE TO THE LATE CENOZOIC MOLLUSCS OF THE MEADE BASIN, SOUTHWEST KANSAS

By

Brian William Steffen

B. S., University of Wisconsin-Milwaukee, 2000

M. S., Fort Hays State University, 2002

\author{
A Dissertation \\ Submitted to the Faculty of the \\ School of Arts and Sciences \\ of the University of Louisville \\ in Partial Fulfillment of the Requirements \\ for the Degree of
}

Doctor of Philosophy

Department of Biology

University of Louisville

Louisville, Kentucky

December, 2010 

TESTING THE USE OF MOLLUSCS TO INFER CLIMATE WITH SPECIAL REFERENCE TO THE LATE CENOZOIC MOLLUSCS OF THE MEADE BASIN, SOUTHWEST KANSAS

By

Brian William Steffen

B. S., University of Wisconsin-Milwaukee, 2000

M. S., Fort Hays State University, 2002

A Dissertation Approved on

November 4, 2010

By the following Dissertation Committee:

Dissertation Dírector

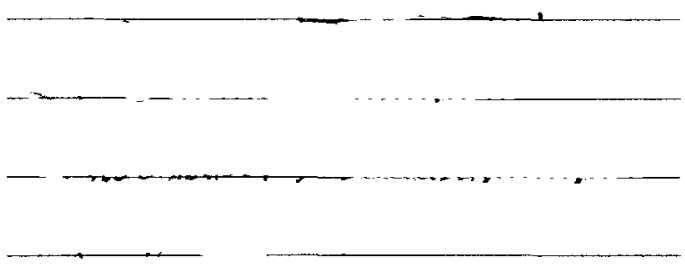




\section{DEDICATION}

This dissertation is dedicated to my family: parents Bill and Toni Steffen and sisters Jenny and Laura.

Their love and support have been valuable assets across the years and miles. 


\section{ACKNOWLEGEMENTS}

I would like to thank my committee members, Dr. James Alexander and Dr. Robert Martin (Murray State University), Dr. Margaret Carreiro, Dr. Lee Dugatkin and Dr. Perri Eason for their help and suggestions in guiding this dissertation to completion. I would also like to acknowledge Dr. Jeff Jack's contribution as well.

Help with species identifications was provided by Dr. James Theler (University of WisconsinLaCrosse) and Dr. Robert Dillon (College of Charleston). I thank them for their time dedicated to this task. Thanks also to Dr. Sarah Derouin (Bureau of Reclamation, Denver Federal Center) for her extensive help with GIS and to Robbie Johnson, who helped with GIS as well. Thanks to Dr. Sarah Emery who provided help with troubleshooting PC-ORD. Allison Smith provided help with editing and deserves my thanks as

well. Lastly, for listening to my concerns and for providing much needed advice, I wish to thank my good friends: Dr. David Schmidt (Wayland Baptist University), Dr. Sarah Derouin and Bethany Ashlock. 


\section{ABSTRACT \\ TESTING THE USE OF MOLLUSCS TO INFER CLIMATE WITH SPECIAL REFERENCE TO THE LATE CENOZOIC MOLLUSCS OF THE MEADE BASIN, SOUTHWEST KANSAS

\author{
Brian W. Steffen
}

November 4, 2010

Twenty-six fossil assemblages of land and freshwater molluscs from the Pliocene to the present, were collected from locations near the town of Meade, Kansas, U.S.A. and were analyzed (along with the extant molluscan fauna of Meade County, Kansas) to look for changes in molluscan diversity through time.

The fossil assemblages were analyzed for two reasons: 1) to test the hypothesis that diversity (measured as taxonomic richness, dominance, turnover and habitat type) did not change through the five million years of this study $\left(\mathrm{H}_{\mathrm{O}_{1}}\right)$; and 2) to test the hypothesis that there is no relationship between the taxonomic composition of a molluscan assemblage and the local climate $\left(\mathrm{H}_{\mathrm{O} 2}\right)$. The latter hypothesis was tested by re-examining prior molluscan paleoecological studies, by analyzing the molluscan assemblages collected for this study and through ordination analysis.

The results of the first analysis clearly showed that the taxonomic structure of the assemblages changed through time ( $\mathrm{H}_{\mathrm{O}}$ was falsified), but the changes appeared to be random fluctuations. Richness ranged from 7 taxa (in assemblages AGO, FAL, RYA, SPA) to $30(\mathrm{CO} B \mathrm{~B})$ with $\mathrm{r}^{2}=0.237$. Dominance ranged from $1.40(\mathrm{SPA})$ to $9.66(\mathrm{RTA})$ with $\mathrm{r}^{2}=0.113$. The Habitat Ratio ranged from $-0.43(\mathrm{FAL})$ to 1.00 (X1E) with $\mathrm{r}^{2}=0.029$ and Turnover ranged from 0.17 (AGO, FAL) to 1.00 (RNT), when each assemblage was compared to RNT $\left(r^{2}=0.024\right)$. No discernable long-tem trend in taxonomic diversity or community composition was observed.

The results of the second analysis indicate that molluscs, as a group, are not as useful as climate indicators as previously supposed. Today, both land and freshwater mollusc species are broadly geographically distributed and thus are found in a variety of locations with different local climates and 
vegetation. Previously, Miller $(1975,1976)$ grouped molluscan species with similar environmental tolerances into four units called Climate Groups and used them to infer the past climatic conditions of a region. However, only a weak climate signal was detected (ANOVA found significant differences among the Groups for minimum temperature $[p<0.0001]$, maximum temperature $[p<0.0001]$ and annual precipitation $[p=0.0082]$ ), after the previous results were reanalyzed using the methods of this study. The fossil molluscan assemblages collected for this study displayed no climate signal (ANOVA found no significant differences among the assemblages for minimum temperature $[p=0.0714]$ or precipitation $[p=$ $0.691]$ but did find a difference in maximum temperature $[p=0.0207]$. A subsequent Tukey-Kramer HSD test failed to find significant differences among assemblages). Finally, the results from ordination analysis of my data did not show a strong relationship between the climate variables used in this study (minimum and maximum temperatures, annual precipitation) and the current geographic distribution of molluscan taxa.

One should proceed with caution if molluscs are to be used to interpret climate. The results of this study do not provide a strong endorsement for using molluscs as paleoclimate indicators. This finding is counter to the prevailing wisdom among paleontologists. More work needs to be done in the area of molluscan biogeography and physiology to see if the conclusions herein hold up and to better understand molluscan biology in general. 


\section{TABLE OF CONTENTS}

\section{PAGE}

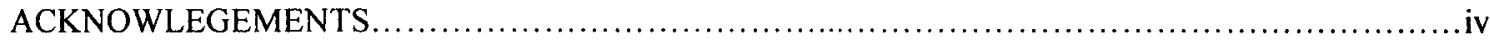

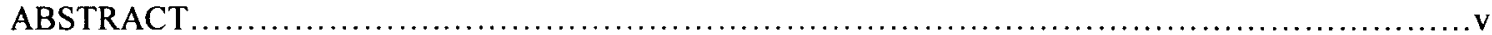

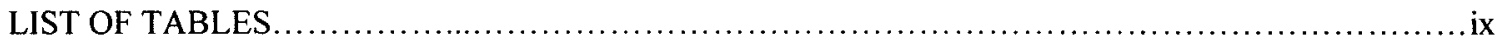

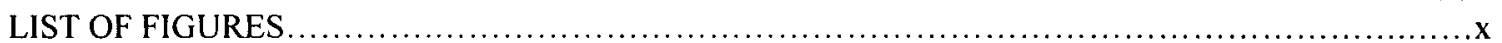

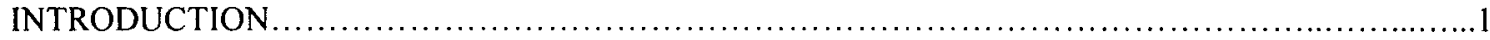

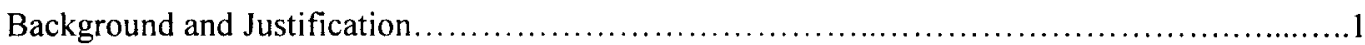

Previous Work: Using Molluscs as Environmental Indicators..................................5

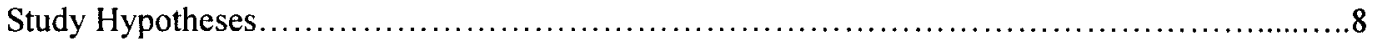

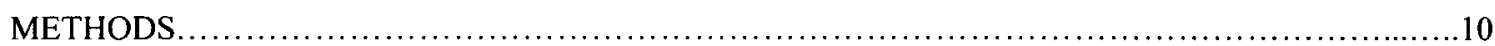

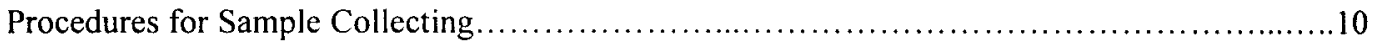

Procedures for Sample Processing: Drying and Washing ..........................................13

Procedures for Sample Processing: Fossil Picking..........................................15

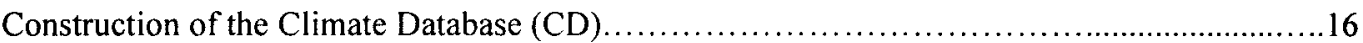

Construction of the Molluscan Biogeography Database (MBD) .............................19

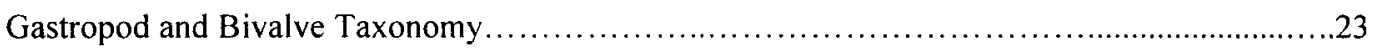

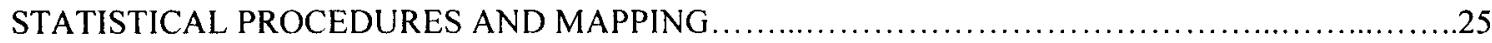

Stasis in Community Structure: Testing $\mathrm{H}_{\mathrm{OI}}$ via Alpha Diversity Statistics......................25

Stasis in Community Structure: Testing $\mathrm{H}_{\mathrm{O}}$ via Beta Diversity Statistics..........................26

Stasis in Community Structure: Testing $\mathrm{H}_{\mathrm{O} 1}$ via Habitat Ratio.....................................26

Species Composition and Climate: Testing $\mathrm{H}_{\mathrm{O} 2}$ via Biogeography and Climate Variables..........27

Species Composition and Climate: Testing $\mathrm{H}_{\mathrm{O} 2}$ via Multivariate Statistics......................29

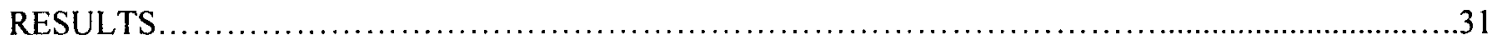

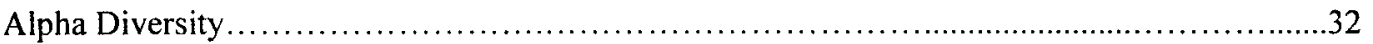




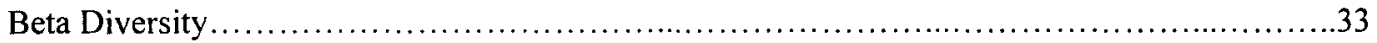

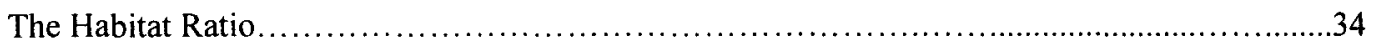

Mapping Biogeography and Climate Variables................................................

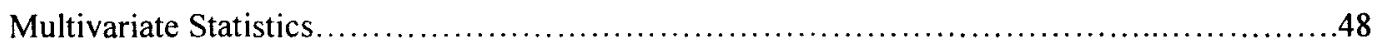

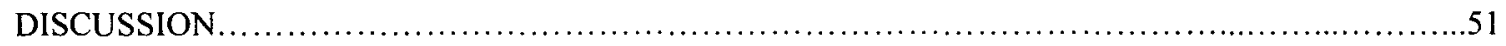

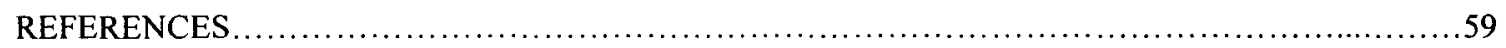

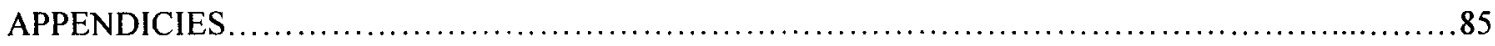

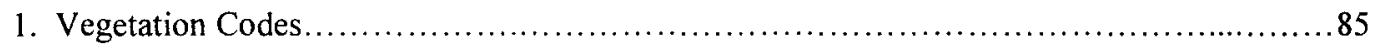

2. Molluscan Biogeography Database Citations............................................ 87

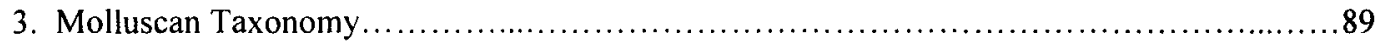

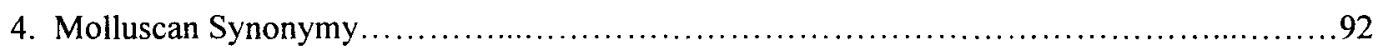

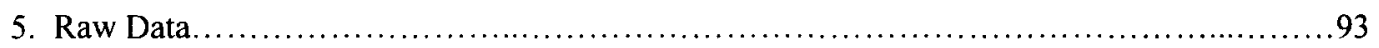

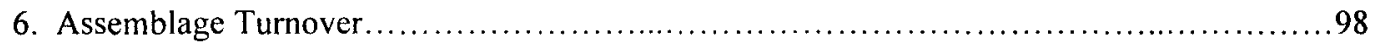

7. Summary of Taxa and their Environmental Tolerances.................................... 100

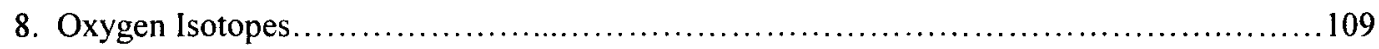

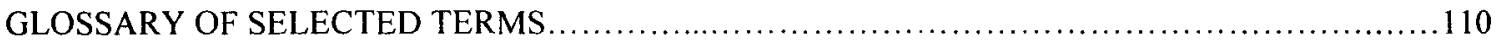

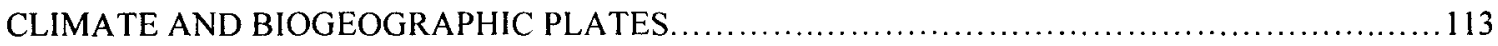

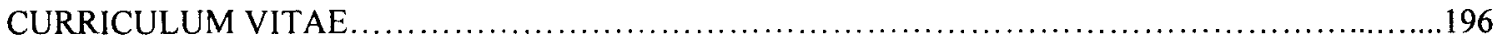




\section{LIST OF TABLES}

PAGE

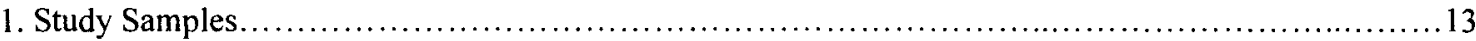

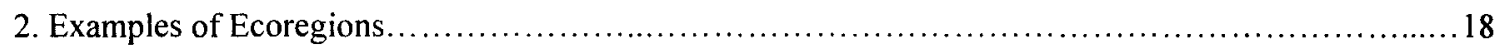

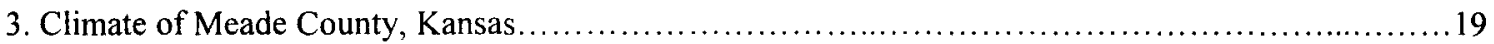

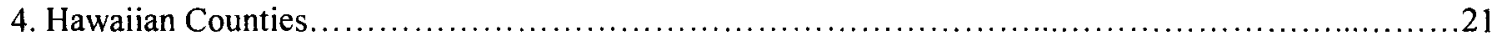

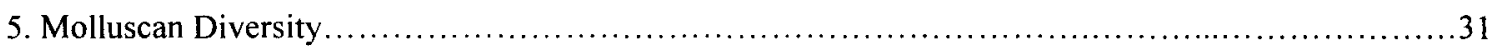

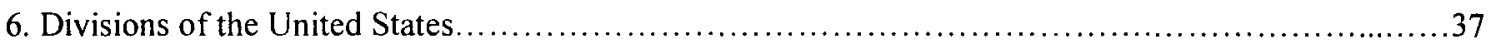

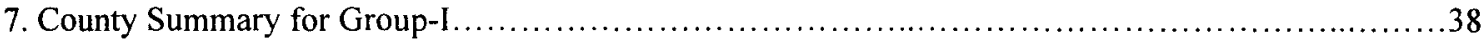

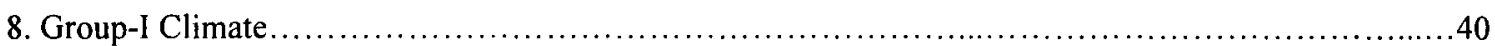

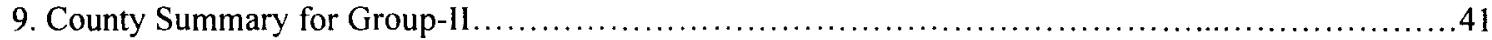

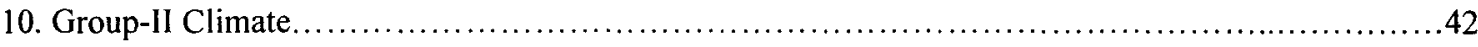

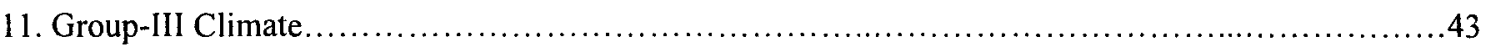

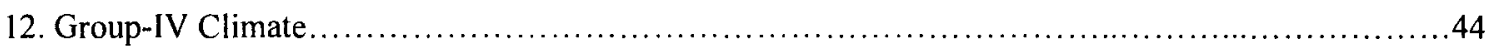

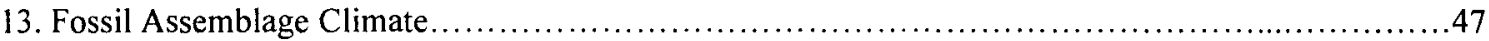




\section{LIST OF FIGURES}

FIGURES

PAGE

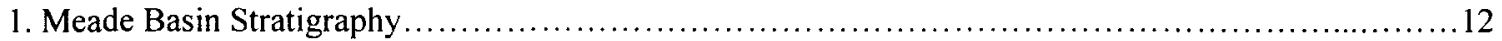

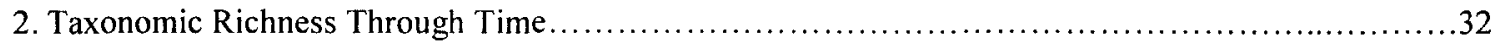

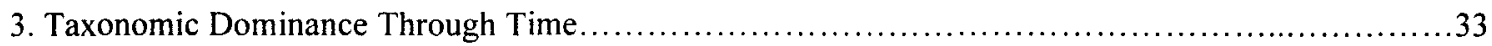

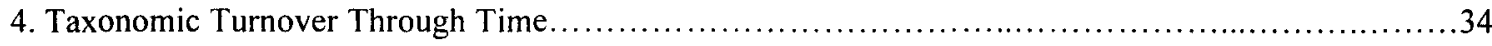

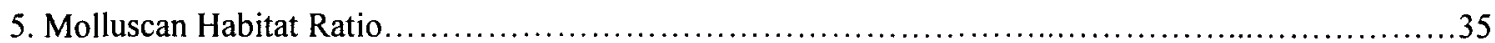

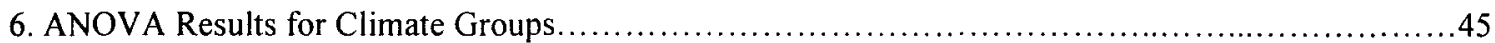

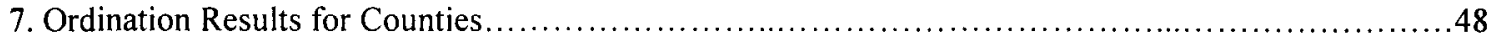

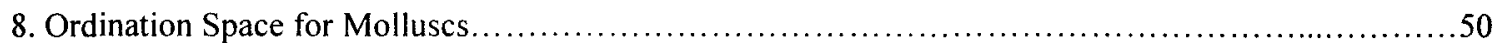

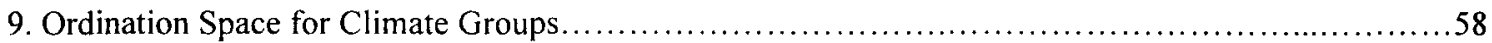




\section{INTRODUCTION}

\section{Background and Justification}

Climate change effects have important implications for the health of the biosphere. While ecologists document and debate the potential effects of climate change on ecological communities, paleoecologists can contribute to the discussion by studying the history of animal assemblages in relation to climate change. The discipline of paleoecology is in a unique position to examine how taxa respond to climate change, because paleoecologists can track organisms over long periods of time.

This study examines the changes in the diversity and biogeography of freshwater and land molluscan assemblages of the Meade Basin, southwest Kansas over the past five million years. This time period spans three geological epochs: the Pliocene (5.33 million years ago [Ma] to 2.588Ma), Pleistocene (2.588Ma to $0.01 \mathrm{Ma})$ and Holocene $(0.01 \mathrm{Ma}$ to present) (Ogg et al., 2008). It should be noted that the debate over the age of the Plio-Pleistocene boundary has not yet been formally resolved. The boundary is currently set at either $2.588 \mathrm{Ma}$ or $1.806 \mathrm{Ma}$ (Ogg et al., 2008). During this time period, three major geological events occurred which dramatically altered the climate. Both freshwater and land molluscs of North America thus had to contend with climate change over time, due to the effects of these overlapping geologic events.

The first geologic event was a rise of the Rocky Mountains; the Rockies attained their current height and morphology within the study period. McMillan et al. (2006) documented the onset of mountain basin-fill erosion beginning $8 \mathrm{Ma}$, and suggested isostatic adjustments and faulting as the probable cause. This final rise of the Rocky Mountains may have extended a rain shadow over the study area. The second major event consisted of three episodes of volcanic eruptions from the Yellowstone supervolcano, dated to approximately 2.003Ma, 1.293Ma and 0.602Ma (Gansecki et al., 1998). These eruptions deposited thick ash layers over a large part of the Rocky Mountains and Great Plains. The third and most recent event consisted of an oscillating series of cold (glacial) and warm (interglacial) periods. There have been 
approximately 17 glacial-interglacial oscillations within the last 1,650,000 years (Morrison, 1991).

In order to examine climate effects on prehistoric molluscan assemblages, a comparative dataset from modern species is needed that reflects the current local climate. This dataset can be produced by examining the ecological requirements of extant molluscs. One of the reasons molluscs are assumed to be limited in their biogeographic distributions is their inability to tolerate all conditions in their physical environment-some locations are too hot or too cold, too wet or too dry to make a living in that area. This aspect of biogeography is reflected in the "Hutchinsonian" concept of the niche as an $n$-dimensional hypervolume (where $n$ represents the number of biotic and abiotic variables which limit the biogeographic distribution of an organism [Hutchinson, 1957]) and the "Gleasonian" concept of an open community (where different species of a community have different environmental tolerances and can act independently of one another to climate changes [Gleason, 1926]). Possible responses by molluscs to climate change include: 1) follow their preferred climate as it moves across the landscape; 2) remain in place and employ physiological and/or behavioral strategies to accommodate the changing climate; or 3) extirpation or extinction as climatic conditions become intolerable.

While changes in climate could be expected to influence molluscan distributions, it must be remembered that molluscs are part of a wider community of organisms that are all reacting to climate changes. Thus the interaction of species might produce changes in biogeography which are different from what might be expected from climate alone (Davis, 1998). Importantly, species biogeographic distributions can be affected by more than just climate variables (Allen and Cheatum, 1961). Also, paleoclimate interpretations should not be based only on molluscan fossils. Additional useful information can be collected in the field, at the outcrop, including strata lithology and sedimentary structures, presence/absence of paleosols and the identity and abundances of co-occurring plant and vertebrate fossils (Frye and Leonard, 1967). These techniques and assumptions have been employed by many authors to interpret paleoclimate. Biotic factors that could influence molluscan biogeography and diversity, such as competition, predation, parasitism and disease were not investigated in this study. It is the abiotic (climatic) factors and their impacts on molluscan biodiversity and biogeography are the sole focus here. Molluscan anatomy, physiology and their seemingly sedentary behavior suggest molluscs could be influenced by climate, making them potentially useful for making paleoenvironmental interpretations: the 
argument is that their soft, permeable bodies make them sensitive to changes in environmental moisture, while their ectothermic physiology makes them sensitive to changes in environmental temperature.

Therefore, a collection of molluscan species living in a location should reflect the conditions of temperature and moisture at that location.

In order to use molluscs as environmental indicators, their tolerances for temperature, moisture and other environmental parameters must first be identified. Unfortunately, a survey of the literature relevant to the biogeography of freshwater and land molluscs of the United States does not provide much useful information. Although some studies provide precise water chemistry data, or air and/or water temperature data for specific collection sites (for example, Basch et al., 1961; Branson, 1966; Jokinen, 1992; among others), such studies are not common. More often, biogeographic publications provide little or no data on the temperature, precipitation or other conditions where molluscs were collected. Some publications do provide vague habitat in formation under the banner of "ecology" or some similar label. For example, Cheatum and Fullington (1973, p. 18) identify Gastrocopta pentodon as "[a] snail of well-drained woodland areas and of meadows associated with sparse vegetation. Leaf litter and other objects serve as cover." Aspects of temperature, precipitation and the species of vegetation that generated the leaf litter were not discussed. Environmental assessments such as these are of limited use as they could be applied to many species of land snails.

To more accurately estimate the temperature, precipitation and other environmental parameters which might limit molluscan distributions, two databases were compiled for freshwater and land molluscs of the United States. The first, called the Climate Database (CD), was a compilation of the temperature, precipitation, vegetation and elevation data of each county in the United States over a roughly 20 year period. The second database, called the Molluscan Biogeography Database (MBD), records extant freshwater and land molluscan distributions by county and is a composite of collection records over a 169 year period. I used these databases (instead of the climatic/environmental assessments from the published literature) to estimate the climate tolerances of molluscan taxa collected for this study and, by extension, the paleoclimate of southwestern Kansas.

The reliability of climate interpretation from fossils rests on at least three assumptions: 1) species biogeographic ranges are limited by tolerances for environmental parameters; 2 ) the environmental 
tolerances limiting a given species are known; and 3) species environmental tolerances have not changed over time. We tentatively accept assumption 1, because molluscan species appear to be limited in their biogeographic distribution, which is reflected in the recognition of molluscan provinces (Burch, 1962; Baxter, 1987; Metcalf, 1997), some of which are more easily delineated than others. Whether these molluscan provinces are solely climate-based, are due to a lack of dispersal ability/opportunity or are due to interactions with other organisms is difficult to determine. Concerning assumption 2 , most taxa examined in this study are extant and their environmental tolerances could be inferred through the use of the CD and the MBD; therefore assumption 2 is satisfied. In addressing assumption number 3, a uniformitarian approach was employed.

Uniformitarianism asserts that present processes (in this case climatic processes) serve as a reliable guide to past processes (Scott, 1963). In the context of paleoecology, it is assumed that if a given extant species has certain environmental tolerances, then its fossil conspecifics also had those same tolerances - evolution did not endow extant individuals with new environmental tolerances that their fossil conspecifics did not have (Scott, 1963). However, while uniformitarianism is a useful assumption, it is difficult to prove. For example, if we consider a hypothetical, extant, cold-adapted species, we would expect it to live at high latitudes and/or high elevations where cold conditions exist. If we find fossils of the same species residing at low latitudes/elevations, we could conclude two very different outcomes: 1) the species has evolved adaptations to cold environments from an initial warm climate preference and moved into the high elevation/latitude areas; or 2) the species did not evolve new tolerances but has tracked its preferred cold climate from the low latitudes/elevations to higher latitudes/elevations as the cold climate moved across the landscape through evolutionary time. If we could not distinguish between these two outcomes, then the presence of a given species in an assemblage is not sufficient to infer climate. However, if we have independent evidence of cold climates at the low latitudes/elevations (as from temperatures recorded in ${ }^{18} \mathrm{O} /{ }^{16} \mathrm{O}$ ratios or other animal groups) and this time corresponds to the arrival of the presumably cold-adapted fossil mollusc in the region, then we can reasonably assume that the mollusc has not evolved new tolerances, but merely migrated with its preferred climatic regime. If evolutionary changes are not occurring, then the mollusc would be a useful guide to the climate of the region. Using a uniformitarian approach and armed with the knowledge of the environmental tolerances of extant 
populations of the molluscan species that comprise the fossil assemblages, fossil molluscs were identified from the Meade Basin of Kansas and their biodiversity tracked through approximately five million years.

The major concerns of this study were to determine if extant molluscs are sensitive to climate variables and to determine if molluscan communities from southwestern Kansas changed through time in ways that are indicative of climate change.

\section{Previous Work: Using Molluses as Environmental Indicators}

Several researchers have used fossil molluscs as environmental indicators or have advocated their use. As previously noted, the extant species are used as environmental analogues for fossil conspecifics (Allen and Cheatum, 1961). Therefore, the co-occurrence of molluscan taxa in a fossil deposit presumably reflects the climate conditions the fossils lived under when they were live (Allen and Cheatum, 1961; Frye and Leonard, 1967). For example, Devore (1975) used fossil molluscs to interpret the climate of a fossil deposit called the sloth locality in Meade County, Kansas. The existence of Physa skinneri, Valvata tricarinata and Pupilla muscorum in this fossil deposit was used to infer cool conditions, as these species are found at more northern latitudes today and, according to Devore (1975), do not currently extend their range into southwest Kansas. Other northern species present at the sloth locality are Stagnicola caperata, Gyraulus circumstriatus, Vallonia gracilicosta and Stenotrema leai. There are southern species present in

this fossil deposit as well, including Physa anatina, Gastrocopta cristata and Vallonia parvula, which were used to suggest that the temperature of the sloth locality was more moderate than today's climate in Meade County, thus allowing for the coexistence of northern and southern species in the same deposit (Devore, 1975).

Wells and Stewart (1987) also used molluscs to infer paleoclimate of western Kansas and the Great Plains. The authors note that snail species which were wide-spread over the Plains during the most recent glacial advance, are restricted today to either the eastern deciduous forest (Hendersonia occulta, Helicodiscus parallelus) or mountainous areas (Oreohelix strigosa, Discus shimekii, Columella alticola) (Wells and Stewart, 1987). These range shifts from Plains to forest/mountain was interpreted to reflect a shift in climate at the end of the Pleistocene from a glacial climate (cooler, wetter) to the nonglacial climate of the Holocene (present) (Wells and Stewart, 1987). 
In the preceding studies, the existence of particular molluscs in a fossil assemblage is sufficient to establish paleoclimate. The work by Miller is more quantitative in that not only are species identities recorded, but the various species are grouped into Climate Groups (explained in more detail below) and the proportions of these Climate Groups are used to infer climate. For example, Miller and Kay's (1981) analysis of the Kanopolis local fauna of Ellsworth County, Kansas, compared with the present molluscan assemblage of the same area, indicated that the fossil fauna was dominated by northern species. The Kanopolis fossil fauna has a 13 -fold increase in numerical abundance of northern species and an eight-fold increase in percent abundance of northern species, relative to the extant molluscan assemblage of Ellsworth County. This data is used to interpret paleoclimate by suggesting that the fossils lived under cooler conditions with more evenly distributed moisture than currently exists in Ellsworth County. Similarly, the Hall Ash Pit molluscan fauna can be compared to the modern molluscs of Jewel County, Kansas (Miller and Eshelman, 1985). The fossil deposit has a greater proportion of northern and eastern species than presently exists in Jewel County. This was interpreted to mean that the climate experienced by the fossils was cooler and wetter than at present.

More examples of paleoclimate studies using molluscan fossils as environmental indicators could be cited but the techniques are similar to those studies cited above. If you accept the assumption that current molluscan biogeography can be used to interpret past climate, then the paleoclimate interpretations and habitat reconstructions which follow from that assumption are reasonable and could be true. However, such studies never provide a test to determine if climate variables are really influencing where molluscs live- that is, the hypothesis that molluscs are living where we find them today, because their physiological constitution and/or life history requires that they live under the climate conditions at those locations, is never tested (in spite of the fact the link is often asserted or invoked to be true). It is possible that other biotic or abiotic factors operate in conjunction with climate factors, to limit where molluscs can live. Just how important climate variables like temperature and precipitation are to molluscan species has yet to be experimentally determined for most species in the United States.

Furthermore, precise knowledge of extant molluscan biogeography of the United States has been lacking: the first detailed, national maps of land gastropod distributions were not published until 1985 by Hubricht (1985) and maps comparable in scope and detail for freshwater species have apparently never 
been published. Accurate knowledge of biogeographic distributions is necessary if molluscs are to be used to reconstruct the paleoclimate history of the United States.

Because Miller's work on paleoclimate is more quantitative than some paleoclimate studies, his methods deserve a closer look. Miller (1975) studied seven molluscan assemblages collected from Meade County, Kansas and nearby Harper County, Oklahoma. These assemblages ranged in age from 30,000 to 10,500 years before present (BP) ("present" is usually defined, for radiometric dating purposes, as the year 1950 [Ogg et al., 2008]). These seven assemblages were composed of 61 molluscan species, all extant, although not all are found in Kansas today. Miller (1975) divided molluscan species into four Climatic Groups: Group-I was composed of northern species whose southern biogeographic limits are presumably controlled by high summer temperatures. Group-Il was composed of southern molluscan species whose northern ranges are believed to be limited by low winter temperatures. Group-III species were eastern species with their western limit possibly controlled by the available moisture. Species in Group-IV were those with inadequate biogeographic range data or have distributions controlled by factors other than climate or were species considered to be eurythermic and/or euryhydric (Miller, 1975). Eurythermic or euryhydric species are not suitable for climate reconstructions. Each fossil assemblage contains species from each Climate Group, in varying proportions. The relative proportions of the four Climate Groups within an assemblage reflected the local climate of southwest Kansas when the fossils were alive. Using these Climate Groups, Miller (1975) determined that the overall climate change of southwest Kansas from approximately $27,000 \mathrm{BP}$ to $10,800 \mathrm{BP}$ was one of increasingly warm summers, as reflected in a decline in proportion of Group-1 species in most assemblages. A loss of freshwater species from Groups-I, II and III suggests a drying climate through this time as well. Specifically, the Jones assemblage (approximately 27,000BP) had the coolest and wettest climate of the assemblages examined by Miller (1975). This cool, wet period is suggested by the presence of a diverse number of Group-I species including abundant freshwater species. From Classen $(16,100 \mathrm{BP})$ to Robert $(11,100 \mathrm{BP})$ assemblages, the climate of southwest Kansas became warmer and drier, as indicated by a decline in Group-I species (especially freshwater species), along with a concurrent expansion of Group-II species. The Boyd assemblage $(10,790 \mathrm{BP})$ demonstrated a brief reversal of climatic trends through an increase in Group-I freshwater species and a decrease in Group-II and III species. This change reflected a return to cooler 
summers and more extreme winters than previously encountered. Since the time of the Boyd assemblage, the molluscan biodiversity has continued to decline to the present. During this time, there has been a great reduction in Group-I species and a greater prevalence of Group-IV species in the extant molluscan assemblage, suggesting a continuation of the warming trend (Miller, 1975).

A second, similar study by Miller (1976), expanded on his previous study by analyzing 21 molluscan assemblages from the Meade area. The 21 assemblages contained 106 molluscan taxa from the mid-Pliocene through the late Pleistocene, 92 of which are extant. Miller (1976) divided these species into the same four Climate Groups based on their environmental tolerances, except that Group-IV now included extinct taxa. The assemblages were plotted on a ternary diagram to look for groupings with ecological significance. Ternary diagrams are graphs often used by petrologists, mineralogists and soil scientists, but these diagrams can accommodate biological and paleontological data (Ehlers, 1972; Hammer and Harper, 2006). When using these graphs, plotted points form clusters if their compositions are similarly proportioned. Dissimilar points plot farther apart.

According to Miller's (1976) Figure 1, the 21 fossil assemblages formed two groups, designated as either glacial (assemblages with more than 50\% Group-I molluscs) or nonglacial (assemblages with less than $50 \%$ Group-I molluscs). The glacial assemblages were more tightly clustered, indicating that the proportion of northern, southern and eastern species did not vary much from assemblage to assemblage through time, although the species composition may have changed. According to Miller (1976), glacial assemblages included the Boyd, Robert, Classen, Bar-M-II, Bar-M-I, Jones, Bird, Mount Scott, Butler Spring, Adams, Doby Springs, Berends and Cudahy assemblages. The nonglacial assemblages were more dispersed, indicating that the ecological proportions varied more through time. Species composition likely varied as well. Nonglacial assemblages included the Recent, Jinglebob, Cragin Quarry, Spring Creek, Sanders, Bender, Rexroad and Saw Rock Canyon assemblages (Miller, 1976). Miller's (1975, 1976) concept of Climate Groups will be investigated in this study as a test of its ability to estimate paleoclimate.

\section{Study Hypotheses}

In order to test the assertion that changes in molluscan diversity reflect climate change, it was necessary to test two different hypotheses. The first null hypothesis $\left(\mathrm{H}_{\mathrm{O}}\right)$ is that there is no change in 
diversity, evaluated as richness, dominance, turnover and habitat type, through time - assemblages display stasis. The alternative hypothesis $\left(\mathrm{H}_{\mathrm{A}}\right)$ is that changes in diversity do take place, either systematically or randomly. Diversity stasis might reflect an unchanging climate for southwest Kansas through the five million year study period. A systematic change in biodiversity, such as a change in richness, dominance or the identity of the taxa present, etc., presumably indicates changes in climate through this time. The pattern of such change can be an important indicator for how climate changed: for example, glacial-interglacial cycles should produce cyclical changes in species composition of the assemblages-cold climate taxa yielding to warm climate taxa, which in turn give way to cold climate taxa, etc. A pattern of random biodiversity change through this time would suggest that something other than climate is controlling molluscan community composition.

Because the assertion that molluscan species are geographically limited by climate has been largely assumed rather than empirically tested, the purpose of the second part of this study is to provide such a test. The second null hypothesis $\left(\mathrm{H}_{\mathrm{O} 2}\right)$ is that there is no relationship between molluscan species composition and climate variables. The alternative hypothesis $\left(\mathrm{H}_{\mathrm{A} 2}\right)$ states that a relationship between molluscan species and climate exists. This hypothesis will be investigated via multiple routes, including reexamining Miller's $(1975,1976)$ Climate Groups, examining the fossil assemblages collected for this study and statistically via nonmetric multidimensional scaling (NMS). In addition, maps of extant species' current biogeographic ranges (by county) and maps of current climate variables (also by county), for all 50 states were generated. 


\section{METHODS}

\section{Procedures for Sample Collecting}

A total of 27 samples were examined in this study. Twenty-five of these samples were collected from strata of southwestern Kansas during the 2005 summer field season. Most samples were collected from private property near the town of Meade (lat $37^{\circ} 17^{\prime} 08^{\prime \prime}$ N., long $100^{\circ} 20^{\prime} 23^{\prime \prime} \mathrm{W}$. [United States Geological Survey \{USGS\}, 2006]), in a geological structure called the Meade Basin (Martin et al., 2000). This area was chosen for analysis because it has one of the most complete sedimentary sequences of the late Cenozoic known in North America (Miller, 1975).

The outcrops of sedimentary strata examined in this study are Pliocene through Pleistocene in age (Miller, 1975; Martin et al., 2008) and are composed of unlithified sediments, with grain sizes ranging from clay to sand in varying proportions. Sample locations were found by Dr. Robert A. Martin and his colleagues, Jim Honey and Pablo Peláez-Campomanes, who have worked in this area for many years. Outcrops are usually erosional features caused by rain and surface runoff eroding escarpments into the landscape. The cliff faces produced by erosion expose multiple sedimentary strata that are distinguishable by sediment color, grain size and/or coherency. Prior to sample collection, the weathered face of the stratum was removed until unweathered sediments were revealed. This was done to remove shells which may have slumped down from higher stratigraphic levels. Samples were removed from the strata with a shovel and/or a stout knife. Enough sediment was removed at each location to fill two $4 \mathrm{~L}$ bags. Loose sediment was deliberately avoided when filling the bags; clods were collected instead because shells would be better protected during transport and handling if they were incased in sediment blocks. The samples were transported to Murray State University for processing.

Two of the 27 samples were not collected by me: Bird-2 (BD2) and Recent (RNT). The BD2 sample was collected by Dr. Martin, independent of my study and was added to my study to fill in a temporal hole in my data set. Its processing protocols do not match my protocols outlined below. 
Meade County's extant molluscan assemblage (which constitutes the RNT sample) was obtained from the published literature. Data on the fingernailcalms/peaclams of Meade County came from Leonard (1943) who found Sphaerium and Pisidium in Crooked Creek, which runs through the county. Gastropod data for Meade County came from Leonard's (1959) gastropod range maps in Kansas. Only those species specifically marked with a symbol in Meade County were recorded as part of the extant assemblage for Meade County.

Figure 1 shows a composite stratigraphic column of the Meade Basin and presents the most recent biostratigraphic hypothesis for the Meade Basin (Martin et al., 2008). Table 1 gives a complete list of the samples (and assemblages) examined in this study. The samples are displayed in stratigraphic order with a few qualifications: the age of $\mathrm{BDL}$ is not known, thus its stratigraphic position is approximate, and $\mathrm{CO} 3 \mathrm{~A}$, $\mathrm{CH} 4$ and $\mathrm{CHY}$ are probably temporally equivalent. The numeric ages provided are estimates derived from published data (Figure 1). RNT, the extant assemblage, must have an age of 0Ma. Ages for RTB, RTA, CL1, and BD2 were derived from corresponding assemblages from Miller (1975), while the age for CL2 was found in Martin et al. (2008). Ages for M35, SPB, and SPA are not known with certainty. M35 was assigned an age of $0.25 \mathrm{Ma}$, and SPB and SPA are arbitrarily assigned $0.30 \mathrm{Ma}$, although they may be younger. $\mathrm{CO} 3 \mathrm{~B}$ is dated at $0.64 \mathrm{Ma}$ because it is directly below the dated Lava Creek B ash (Figure 1). $\mathrm{CR} 7$ is younger than $\mathrm{CO} 3 \mathrm{~B}$ but the exact age is unknown. It is believed to be close in age to CO3B as it lies directly above the Lava Creek B ash ( $R$. A. Martin, oral communication), so an arbitrary age of $0.60 \mathrm{Ma}$ was assigned to CR7. Samples CO3A, CH4, CHY, PMA, B1B, X1E, X2B, R1A, RYA, TFC, FAL, and AGO can be found in Figure 1. The ages assigned to these samples are the mean (rounded to the nearest hundredth place) of the beginning and ending date of the magnetic polarity event within which the samples exist. This method of assigning ages often resulted in multiple samples with the same age, implying that they were formed at the same time, which may not be the case. To give each sample a unique age, a "dummy digit" was placed in the thousandths place. The value of this dummy digit varied with the stratigraphic position of the sample—older samples were assigned larger dummy digits, younger samples were assigned smaller dummy digits. Some samples (BDL, JQB, JQA and RFX) do not occur in the literature and their numeric ages are unknown. Their approximate age and relative order are known via stratigraphic and biostratigraphic information. Numeric ages were assigned to these samples by calculating 
the mean of the ages of the assemblages immediately before and after them.

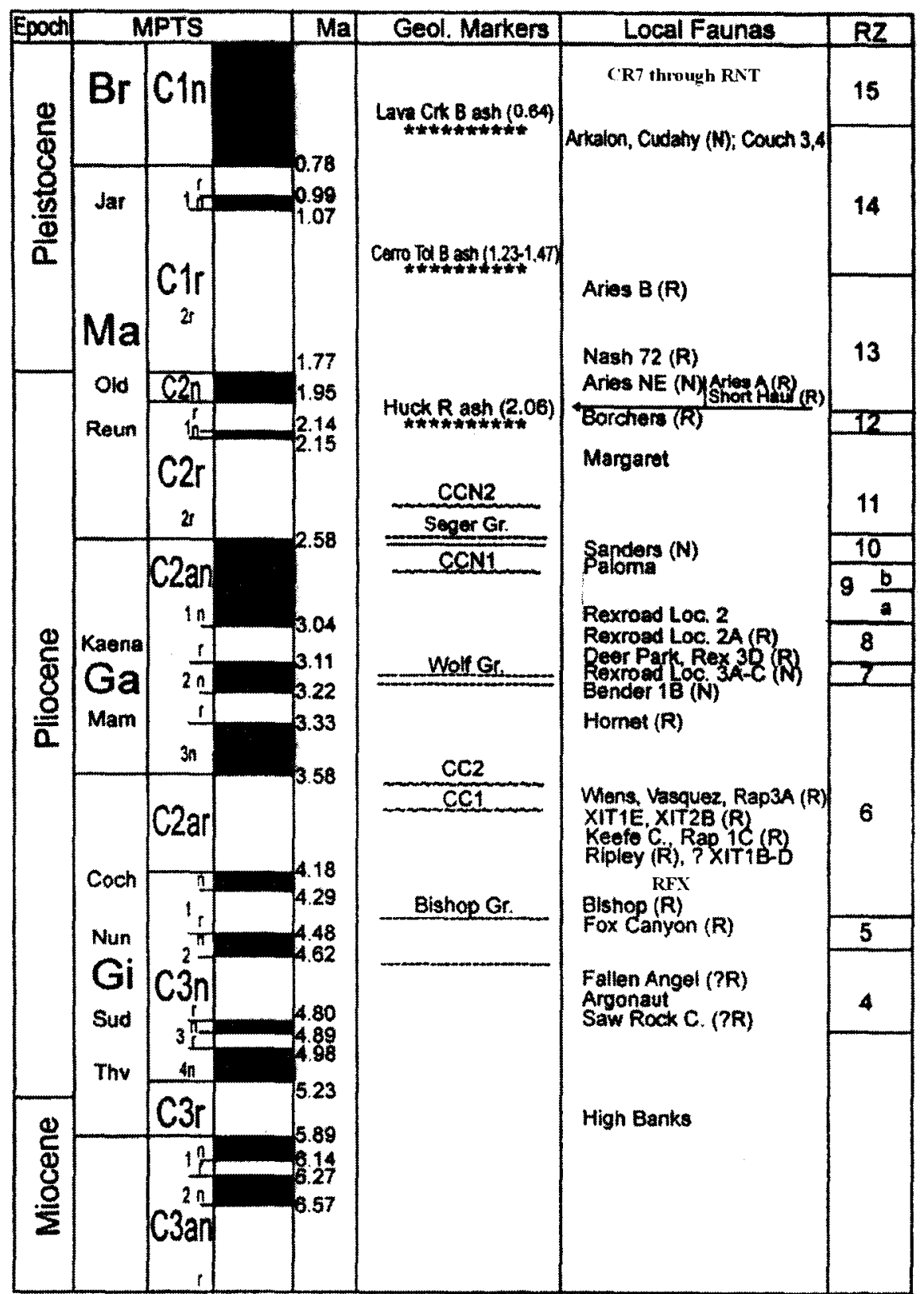

Figure 1. Meade Basin Stratigraphy. The geologic time scale for the Meade Basin (modified Figure 1 from Martin et al. [2008]) showing mammalian (and some molluscan) assemblages. MPTS-magnetic polarity time scale; Geol.--geological; RZ--rodent zones; $\mathrm{N}, \mathrm{n}$-normal magnetic polarity; $\mathrm{R}, \mathrm{r}$-reversed magnetic polarity. 
Table 1. Study Samples. Samples are in stratigraphic order. Time is in millions of years (Ma) before present. See text for a discussion on how dates were derived. 'Approximate stratigraphic location, actual position is unknown. ${ }^{2}$ Samples are possibly temporally equivalent.

\begin{tabular}{cccc}
\hline SAMPLE/ASSEMBLAGE & SYMBOL & EPOCH & AGE (Ma) \\
\hline Recent & RNT & Holocene & 0 \\
Robert-B & RTB & Pleistocene & 0.011 \\
Robert-A & RTA & Pleistocene & 0.012 \\
Bob Dole & BDL & Pleistocene & 0.013 \\
Golliher-B & CL2 & Pleistocene & 0.014 \\
Golliher-A & CL1 & Pleistocene & 0.02 \\
Bird-2 & BD2 & Pleistocene & 0.03 \\
Jim's Quarry-B & JQB & Pleistocene & 0.141 \\
Jim's Quarry-A & JQA & Pleistocene & 0.142 \\
Unnamed & M35 & Pleistocene & 0.25 \\
Scorpion-B & SPB & Pleistocene & 0.301 \\
Scorpion-A & SPA & Pleistocene & 0.302 \\
Couch Ranch Above Ash & CR7 & Pleistocene & 0.60 \\
Lava Creek B Ash & CO3B & Pleistocene & 0.64 \\
CO-3A Below Ash ${ }^{2}$ & CO3A & Pleistocene & 0.711 \\
Couch-4 & CH4 & Pleistocene & 0.712 \\
Cudahy & CHY & Pleistocene & 0.713 \\
Paloma & PMA & Pliocene & 2.81 \\
Bender-1B & B1B & Pliocene & 3.28 \\
XIT-1E & X1E & Pliocene & 3.881 \\
XIT-2B & X2B & Pliocene & 3.882 \\
Raptor-1A & R1A & Pliocene & 3.883 \\
Ripley-A & RYA & Pliocene & 3.884 \\
Red Fox & RFX & Pliocene & 4.14 \\
Taylor's Fox Canyon & TFC & Pliocene & 4.39 \\
Fallen Angel & FAL & Pliocene & 4.711 \\
Argonaut & AGO & Pliocene & 4.712 \\
& & & \\
& &
\end{tabular}

\section{Procedures for Sample Processing: Drying and Washing}

Sample drying and washing were conducted on the campus of Murray State University and at Murray State University's Hancock Biological Station. Samples were processed using procedures similar to those of Hibbard (1949) and McKenna et al. (1994) but modified to accommodate the smaller volume of sediment processed in this study. Each sample was spread out on its own $61 \mathrm{~cm} \times 70 \mathrm{~cm}$ plastic sheet and air-dried for one week, after which the samples were sufficiently dry for further processing. All samples were dried concurrently. Each sample was then loaded into its own 49L trash bag for storage until it could be washed. After drying and prior to bagging, a clod of sediment was removed from each sample to serve as an example of the prewash sediment texture. Each clod was placed in its own $59 \mathrm{ml}$ container and labeled.

Dried sediment samples were washed individually. The chosen sample was loaded into an $11 \mathrm{~L}$ 
tub and enough tap water was added to cover the sample to a depth of approximately $2 \mathrm{~cm}$. The sample was then left to soak overnight. (Soaking was necessary to disaggregate the sediment grains, turning the sample into mud.) The following day, the sample was transported to the boat dock of the Hancock Biological Station on Kentucky Lake for washing. A ladle was used to divide the sample into $200 \mathrm{ml}$ subsamples by scooping the mud into a beaker. Each subsample was washed individually by pouring it into a stacked set of sediment sieves to separate fossils from mud. The sieves used were circular, brass, US Standard Sieves, made by the Dual Manufacturing Company (Chicago, Illinois), with mesh sizes \#16 (1.19mm) and \#35 $(0.50 \mathrm{~mm})$, both with an internal diameter of $20.5 \mathrm{~cm}$. A hose and pump provided water from Kentucky Lake which was flushed over the sample to remove fine sediment, leaving fossils and coarse sediment behind. The fossils and remaining sediment from each subsample were unloaded onto their own $61 \mathrm{~cm} \mathrm{x}$ $70 \mathrm{~cm}$ plastic sheet. The sieves were then cleaned and reused for the next subsample. This process was repeated until the entire sample was washed, producing several subsamples from each sample. Each subsample was washed separately and the recovered fossils and coarse sediment were kept separate.

When using water from a natural source for washing, there is the possibility of contamination by snails from the water source itself. To determine if contamination occurred, two sieves (\#35 and \#230 [0.06mm]) were set up in a similar manner to that used for washing. A hose was placed in such a way that lake water discharged into the sieves for 30 minutes. Afterwards the sieves were rinsed onto plastic sheets to check for contaminating shells. No shells were found.

The fossils and coarse sediment from each subsample of a sample were dried in a greenhouse. On a table, each plastic sheet was spread out and left to air-dry for one day. After drying, each subsample was loaded into its own $946 \mathrm{ml}$ plastic lunch bag for storage. All the bagged subsamples of the same sample were placed together in a $4 \mathrm{~L}$ plastic bag and labeled. These procedures were repeated for all subsequent samples.

Sample CO3B would not wash in the manner outlined above, as most sediment grains would not disaggregate upon soaking. To partially rectify this, the sample was divided into approximately $200 \mathrm{~cm}^{3}$ subsamples by breaking clods into smaller pieces with a rock hammer. Only a small proportion of the sediment was removed upon washing, but many shells were released from the sediment. An unknown number of shells remained trapped in the clods which did not disaggregate and are not accessible for study. 
The drying process was the same as for all other samples.

\section{Procedures for Sample Processing: Fossil Picking}

Fossil picking began at Murray State University in 2005 and was finished at the University of Louisville by 2010 . Once a sample was chosen to work on, each subsample of that sample was picked individually. A small portion of the washed and dried subsample was removed from its bag with a small beaker and poured into a petri dish. The petri dish was then examined through a stereomicroscope under $10 \mathrm{X}$ or $30 \mathrm{X}$ magnification as needed. Sediment and fossils were manipulated as necessary with a curved dissecting needle and a 00-size paintbrush.

To "pick" a fossil, paintbrush bristles were moistened with water and touched to a shell, which then adhered to the bristles. Usable shells were thus removed from unusable shell fragments and coarse sediment and placed in the wells of a spot plate. Each well received a different shell morphology—pupoid, discoid, conispiral, etc. When full, the contents of each well were transferred to $10 \mathrm{~mm} \times 75 \mathrm{~mm}$ test-tubes for temporary storage. After the sediment in the petri dish was fully picked for shell material, it was transferred to a jar for temporary storage. Another small portion of the same subsample was obtained and the process was repeated until the subsample was completely picked through. When finished with a subsample, the picked sediment was returned to its plastic bag for permanent storage. Another subsample from the same sample was chosen for picking and the process was repeated until the entire sample was completed.

Once a subsample was finished, each shell was identified and counted. Complete, adult shells were the most useful for identification, but identifiable shell fragments and juveniles distinctive enough to be identified were also collected. For gastropods, an identifiable fragment often included a complete aperture or spire. No gastropod opercula were recovered. Identifiable bivalve fragments contained the hinge. Each taxon of mollusc for a given sample was loaded into its own $7 \mathrm{ml}$ vial for permanent storage, thus freeing the test-tubes to be reused (all the shells of a taxon from each subsample were combined in these vials for that sample). The contents of the vials were labeled with the name of the sample and mollusc.

Virtually all the complete shells picked were less than $5 \mathrm{~mm}$ in greatest dimension-within the 
"small" shell group of Burch (1982) (10mm or less). There appeared to be a taphonomic bias against the preservation of larger shells (that is, shell consumption by small animals, chemical dissolution, overburden pressure, etc., have operated to crush larger shells but spare the smaller shells). With rare exceptions, larger shells were only present as fragments that contained no taxonomically useful characters.

\section{Construction of the Climate Database (CD)}

Climate and related data were collected for all counties and similar political subdivisions in all 50 states of the United States and the United States capital. Counties were chosen as the basis of the CD to follow Hubricht (1985), who used counties as his unit of biogeography. The list of counties was dictated by a file which was downloaded into $\operatorname{ArcMap}^{\circledR}$ version 9.1. The CD (and MBD, see below) was joined to the file in $\operatorname{ArcMap}^{\text {B. }}$. To do this, the databases needed to use the same list of counties. The CD exists as a Microsoff ${ }^{\mathbb{R}}$ Excel ${ }^{\mathbb{D}}$ spreadsheet with climate and related attributes as column labels and states and counties as row labels.

Forty-eight states are divided into counties as their political subdivisions, so their use in the $\mathrm{CD}$ was straight-forward (National Oceanic and Atmospheric Administration [NOAA], 1978a, b; Rand Mc.Nally, 2009a, b, c). However, the remaining two states require some explanation: Louisiana is divided into political subdivisions called parishes (Rand Mc.Nally, 2009a, b, c) and Alaska is divided into two types of subdivisions called boroughs and census areas (Rand Mc.Nally, 2009a, b). Alaska's 28 subdivisions are not often depicted on maps; for this reason they are listed here: Aleutians East, Aleutians West, Anchorage, Bethel, Bristol Bay, Denali, Dillingham, Fairbanks North Star, Haines, Hoonah-Angoon, Juneau, Keni Peninsula, Ketchikan Gateway, Kodiak Island, Lake and Peninsula, Matanuska-Susitna, Nome, North Slope, Northwest Arctic, Prince of Wales-Outer Ketchikan, Sitka, Skagway, Southeast Fairbanks, Valdez-Cordova, Wade Hampton, Wrangell-Petersburg, Yakutat, Yukon-Koyukuk. The interested reader can consult USGS (2006) and/or Rand Mc.Nally (2009a, b) for the locations of Alaska's boroughs and census areas. For the purposes of the $\mathrm{CD}$, parishes, boroughs, census areas and counties were regarded as equivalent units—-hereafter called "counties." In addition, some states have independent cities which are not part of any county (for example the city of St. Louis, Missouri, is a distinctly different political entity from St. Louis County, Missouri, which contains the city); these cities were regarded herein 
as counties in their own right. Lastly, the capital of the United States was regarded as its own "state" (District of Columbia) containing one "county" (Washington), identical to its state. In total, the CD contains 3142 counties.

Within each county, one "reference city" was chosen to represent its county. Two sources (NOAA [1978a, b] and USGS [2006]) were employed in the choice of reference cities. A given reference city was selected if it could be identified in both sources. An attempt was made to choose reference cities which were centrally located within their counties, but exceptions were sometimes necessary. Some counties mapped by NOAA (1978a) did not display any cities. In those cases, reasonable reference cities were chosen using USGS (2006) only. In other cases, no centrally located cities could be found in both sources, so more peripherally located cities were chosen instead. The reference city chosen for the United States capital was Washington D. C., which was identical to both its county and state. Independent cities were used as their own reference cities. For every reference city, latitude and longitude data was collected from USGS (2006).

Data for climate and related variables (elevation, temperature, precipitation and vegetation) were collected at the reference cities' locations and assumed to apply throughout their respective counties (the smaller the county, the more likely this assumption was true). Elevation data was collected in feet using USGS (2006), and converted to meters. Temperature and precipitation data were collected in English units, and converted to metric equivalents (degrees Fahrenheit to degrees Celsius, inches to centimeters). Temperature data were collected from maps of mean minimum temperatures for January and mean maximum temperatures for July (NOAA, 1978a, b). Precipitation data were collected from maps of mean annual values (NOAA, 1978a, b). NOAA's (1978a, b) maps contain data compiled from the 1930s through the 1950s, and sometimes through 1970. Where isotherm and isohyetal lines on these maps touched or crossed reference cities, the value of that "isoline" was assigned to that reference city and, by extension, to its county as a whole. Where reference cities were located between two isolines, the mean value of the isolines was assigned to that reference city and county. On rare occasions, the maps were not sufficient by themselves, so data were collected from published tables (NOAA, 1978a) and/or from USGS (2006) for the nearest useable source.

Vegetation data for the CD was recorded as ecoregions, which are defined by Bailey $(1983,1995$, 
2005) as geographic areas within which ecosystems occur in spatial patterns determined by differences in the distribution of climate and vegetation. Bailey (1983) outlines a hierarchical system of nested “climatofloral," geospatial units (Table 2).

Table 2. Examples of Ecoregions. Ecoregion units based on Bailey $(1983,1995,2005)$ and United States Fish and Wildlife Service (1982a, b), with examples.

\begin{tabular}{ccc}
\hline ECOREGION UNIT & EXAMPLE & CODE \\
\hline Domain (broadest) & Humid Temperate Domain & 2000 \\
Division & Prairie Division & 2500 \\
Province & Tall-grass Prairie Province & 2530 \\
Section (narrowest) & Bluestem-Grama Prairie Section & 2533 \\
\hline
\end{tabular}

Domains are groups of similar climates and cover the broadest areas. Divisions are subdivisions of Domains and are defined by differences in local climate (spatially and/or seasonally) as well as by the vegetation that area can support. A Province is a subdivision of a Division and is defined primarily by the identity of the climax vegetation existing over that area. Finally, a Section is a subdivision of a Province and is identified by local differences in floral species of the climax vegetation (Bailey, 1983). Data on vegetation were collected using United States Fish and Wildlife Service (USFWS) maps (1982a, b) which used the ecoregion convention mentioned above. The location of each reference city was estimated on these maps and the ecoregion Section (rarely Province), hereafter called "vegetation," identified at that location was recorded for the reference city and assumed to represent the vegetation of its county as a whole. (Again, the smaller the county, the more likely this assumption was true.) Appendix 1 lists all the alphanumeric codes for the vegetation units which occur in the CD, as well as their names (USFWS, 1982a, b).

Table 3 displays climate and related data collected for Meade County, Kansas, as an example of the information contained in the CD. For comparison, similar data for the town of Meade, Kansas, for the year 2008 are: mean minimum daily temperature for January $=-4.6^{\circ} \mathrm{C}$, mean maximum daily temperature for July $=36.2^{\circ} \mathrm{C}$ and minimum estimate of the total precipitation for the year $=53.90 \mathrm{~cm}$ (derived from NOAA [2009]). 
Table 3. Climate of Meade County, Kansas. Climate and related variables and data recorded for Meade County, Kansas, as an example of the data recorded for the entire United States.

\begin{tabular}{l|c}
\hline \multicolumn{1}{c|}{ VARIABLE } & DATA \\
\hline State & Kansas \\
County & Meade \\
Reference City & Meade \\
Latitude (N) & $37^{\circ} 17^{\prime} 08^{\prime \prime}$ \\
Longitude (W) & $100^{\circ} 20^{\prime} 23^{\prime \prime}$ \\
Elevation $(\mathrm{m})$ & 761 \\
Mean Minimum January Temperature $\left({ }^{\circ} \mathrm{C}\right)$ & -6 \\
Mean Maximum July Temperature $\left({ }^{\circ} \mathrm{C}\right)$ & 36 \\
Mean Annual Precipitation $(\mathrm{cm})$ & 46 \\
Vegetation & 2533 (Bluestem-Grama Prairie Section) \\
\hline
\end{tabular}

\section{Construction of the Molluscan Biogeography Database (MBD)}

The MBD, and the maps generated from it, was modeled after the biogeographic range maps published by Hubricht (1985). Biogeography records were obtained entirely from the literature; no museum specimens were examined and no specimens were field-collected.

The MBD exists as a Microsoft ${ }^{\mathbb{E}}$ Excel ${ }^{\mathbb{}}$ spreadsheet with taxa as column headings and states and counties as row headings. The MBD was constructed using the same county list as the CD. Each cell is occupied either by a 1 (the taxon is known from the literature to exist in the indicated county) or a 0 (the taxon has not been recorded in that county). If a publication claimed that a mollusc (gastropod or bivalve, freshwater or land) was collected somewhere in a county, then the mollusc was assumed to occur everywhere in that county; this assumption deliberately ignores differences in microclimate and macroclimate which may be important to molluscan species distributions. No distinction was made between native and introduced occurrences, except for Hawaiian members of the Physidae, Succineidae and Pisidiidae. The presence of these families in Hawaii was recorded in the MBD only if one or more member species are regarded by the literature to be native to the Hawaiian Islands or the species also have ranges in the continental United States. Biologically, a 1 recorded in the MBD, reflects the existence of that mollusc in that county; however, a 0 reflects either 1) the true absence of that mollusc from that county; 2) the mollusc exists in that county but was not collected from that county at the time of the publications' print dates; or 3) a publication identifying the mollusc as present exists but was not located for use in this study.

The molluscs that resided in lentic freshwater bodies (lakes, ponds, reservoirs, ephemeral puddles, 
etc.), were recorded as present in the county in which the water body exists. A species was assumed to occur throughout the entire lentic water body, unless otherwise noted in the literature. In those cases where a lentic water body forms the boundary for two or more counties, geographic information provided by the publications' authors (local town, named bay, stream inlet/outlet, island, etc.) identified the county to which the molluscan species was recorded. If an author provided no geographic information, then the mollusc was assigned to all counties whose borders extend into the lentic water body. Lotic water systems (streams, canals, ditches, etc.) were treated in the following manner: publications, or records within publications, which identified molluscs as existing in a particular lotic system but without providing additional geographic information were not used. When authors recorded mollusc occurrences relative to a locatable geographic point (dam, falls, tributary mouth, town, etc.), the county in which these geographic points exist was located and the mollusc recorded as present in that county. Where a lotic system forms the boundary for two counties and which county is intended by the publications' authors is not clear, the mollusc was recorded as present in both counties.

The literature displayed multiple ways to report biogeographic data. Some publications simply listed county occurrences without providing specific location information (for example, Hubricht [1965]). With these publications, a 1 was recorded in the $\mathrm{MBD}$ if presence was indicated. Other publications provided location information in the form of coordinates (as in Metcalf and Smartt [1997]). In these cases, the county in which the coordinates existed was identified and a 1 was entered in the MBD without consideration of the actual location provided. Some publications displayed biogeographic information as symbols on maps to indicate the approximate locations where molluscs were collected (as in Leonard [1959]). The county in which the symbol was displayed was identified and a 1 was entered into the MBD. In those instances where the symbol was centered on the border defining two counties and no additional information was available to indicate which county was intended, that mollusc was recorded as present in both counties. Other publications identified molluscs collected relative to a geographic feature, such as a town, bridge or road (for example, Branson [1973]). In these cases, the county in which the feature resides was identified and the mollusc was assigned to that county in the MBD. A few publications displayed species occurrences on maps by "inking-in" counties in which a particular species is known to occur (similar to Hubricht [1985]). Several publications provided biogeographic information in more than one 
format.

Only two usable publications could be located which dealt specifically with the molluscs of the United States capital: Lehnert (1885) and Richards (1934). Both references referred to species collected in Washington D. C. itself, as well as in the "vicinity," usually without specifying which species were collected in the capitol and which were collected in the vicinity. With respect to these two publications, it was assumed that all recorded species were collected within the boundaries of Washington D. C. and were recorded as such in the $\mathrm{MBD}$.

Special biogeographic problems are associated with Hawaii. Hawaiian publications (and some publications from other states) identified molluscs as present on islands rather than in counties. This was remedied by identifying the county in which the indicated island existed and attributing the molluscs to that county (Table 4). The Island of Moloka'i provided a complication because it is divided between two counties. Species distributions for the relevant counties of Moloka'i Island were addressed as follows: if a species was recorded as present on Moloka' $i$ Island, the species was then recorded as present in both Kalawao and Maui Counties. However, if a species was recorded on any other island within Maui County, then the species was recorded as present in Maui County only and not in Kalawao County. If collection sites on Moloka' $i$ Island were listed as coordinates or as a reference to a locatable geographic feature (city, river, etc.) which specified in which county, Maui or Kalawao County, the collections were made, then this information was used to place the mollusc in the appropriate county in the MBD.

Table 4. Hawaiian Counties. Hawaii's counties and the major islands they contain (United States Geological Survey, 2006; Rand Mc.Nally, 2009c).

\begin{tabular}{cc}
\hline HAWAIIAN COUNTIES & MAJOR ISLANDS \\
\hline Hawaii & Hawai'i \\
Honolulu & O'ahu \\
Kalawao & Moloka'i (part) \\
Kauai & Kaua'i, Ni'ihau \\
Maui & Kaho'olawe, Lāna'i, Maui, Moloka'i (part) \\
\hline
\end{tabular}

Publications or records within publications that identified molluscs as present in large, vague, geographic areas such as whole states, parts of states, stream drainages, ecoregions, faunal zones, etc., and did not provide additional location information like coordinates, names of local towns, lakes, county 
names, etc., were not used because it was difficult to accurately integrate this information into the MBD.

This procedure may have the negative effect of underestimating species richness within a given county, but has the positive effect of ensuring greater spatial accuracy for the species which are recorded.

Some authors distinguish between different categories of "presentness." Any mollusc recorded as having been collected alive from a county was recorded as present in the MBD. Any mollusc recorded as present in a fossil/subfossil condition was not recorded. Publications, and records within publications, that listed shells as Pleistocene in age or older were not used. However, biogeographic records for empty shells stated as recent, living, extant or historical (interpreted to mean that the animals were alive in a given area within a few decades prior to the publications' print dates) were included in the MBD. Any shell that was explicitly stated to have been transported to the location where it was collected (a "drift" shell) was interpreted as not present (this step was taken because transported shells may have come from an area with a different local climate than the location where the shell was finally recorded). If a mollusc shell was recorded as collected from a location but there was no mention of the shell being a fossil and/or transported or whether it was collected alive or as an empty shell, then that mollusc was recorded as present in that county. Some biogeographic literature is difficult to interpret; where information was unclear, reasonable interpretations were made of the authors' intentions concerning geographic locations, using USGS (2006), Rand Mc.Nally (2009c) and my own intuition.

Taxa in the MBD were recorded at the species level with the exception of the Physidae, Pisidiidae and Succineidae, which were recorded to family. All subspecies of a species mentioned in the literature were recorded together under the species rank. Molluscs identified to the family level were recorded as follows: if any member of these families was located in a county, then the entire family was identified as present in that county without specifying the actual species. This convention was used to match the lack of specificity in identifying fossil members of these same families (see below).

The molluscs listed in the MBD are the same as the fossils picked from the investigated samples, minus extinct taxa and Euchemotrema sp., for a total of 62 taxa. This database should be regarded as a work in progress, as new information will be added as it becomes available. The molluscan biogeographic references consulted to construct the MBD are cited in Appendix 2, in addition to the References section. Appendix 2 also displays a graph depicting the frequency of publication dates (by decade) for the literature 
used in constructing the MBD. These publications do not represent a random sample of all available biogeographic literature, but their inclusion in the MBD was based on usefulness of the biogeographic information provided, not publication date.

\section{Gastropod and Bivalve Taxonomy}

The collected fossil molluscs were identified in part by using published taxonomic keys, especially Burch $(1962,1982)$. Additional help with identification was provided by Drs. James L. Theler, Robert T. Dillon, Jr. and James E. Alexander, Jr., who collectively checked the taxonomic assessments of most taxa. The names assigned to fossil gastropods were mostly derived from available keys (Burch, 1962, 1982). However, where necessary, the species names were updated to reflect current taxonomic understanding using the Integrated Taxonomic Information System--ITIS (2006) as the nomenclatural standard. See Appendix 3 for the complete taxonomic listing of all taxa examined in this study.

Although attempts were made to use available taxonomic keys, several issues prevented rigorous application of this technique and instead required identification of shells by visual comparison with published figures: 1) many taxonomic keys use characters from soft anatomy which are not available from fossils; 2) some characters of extant shells (such as transparency) were unusable because fossil shells were opaque and shell color was altered from the natural state by various chemical influences; 3 ) on occasion the current biogeography was used by a few keys to distinguish shells: current biogeography may not bear any relation to fossil biogeography; and 4) although some shells escaped breakage, a large number of shells exhibited some degree of shell loss. Attempts were made to collect the best of the broken shells, but the fact that some specimens were represented by fragments meant that published accounts of shell size or whorl count could not be used reliably in their identification.

Fossil shells were identified to the species level whenever possible (subspecies were not recognized). A few exceptions were necessary: peaclams/fingernailclams were collected from several samples but were only identified to the family level-_.Pisidiidae (= Sphaeriidae of older literature). Succineid gastropods were only identified to family (Succineidae) because their shells are morphologically variable and thus are not taxonomically useful (Miles, 1958). Lastly, physid shells were only identified to family (Physidae) for two reasons: most shells were those of juveniles, which lack the characters needed to 
identify them to species, and because the taxonomy of this group is in flux. Crossbreeding experiments among many extant species of physids have demonstrated interfertility among several currently distinguishable species, necessitating synonymy, while preserving the identity of others (Dillon, 2009; Dillon et al., 2002, 2005, 2007).

There are two species of slug relevant to this study: the extant Deroceras laeve, native to North America (Taylor, 1954; Chichester and Getz, 1973), and the extinct Deroceras aenigma (Leonard, 1950). According to the literature, these two species can be distinguished by shell morphology. D. aenigma shells are said to be larger and "heavier" than D. laeve shells (Leonard, 1950; Taylor, 1954), but the literature is not consistent. Leonard (1950) measured the holotype of $D$. aenigma to be $4.0 \mathrm{~mm} \times 2.5 \mathrm{~mm}$ but provided no corresponding measurements for $D$. laeve. Taylor (1954), in contrast, measured shells identified as $D$. aenigma to be $5.0 \mathrm{~mm} \times 3.0 \mathrm{~mm}$ and $D$. laeve to be $4.0 \mathrm{~mm} \times 2.5 \mathrm{~mm}$. Given the overlap in size, it is possible that these two species of Deroceras are conspecific with variable shell morphology. In this case, the name D. laeve has priority under Article 23 of the International Code of Zoological Nomenclature (International Commission on Zoological Nomenclature [ICZN], 1999) and should be applied to all shells previously identified as $D$. aenigma. This convention was pursued here, although by this action, formal alteration of the taxonomic status of $D$. aenigma is not advocated.

Lastly, in the construction of the MBD, the taxonomic names used were the same as those applied to the collected fossils, derived from recent publications and often confirmed by experts. Many of the molluscan biogeographic publications are decades-old and employ names available at the time of publication. Many species used in this study have been repeatedly renamed or had their spellings changed due to error or to the necessary changing of suffixes to accomplish genus-species gender agreement. Additionally, some species were synonyms. The older names were used in the construction of the MBD if they could be related to the current name in a single published work. Using this criterion, some synonyms might have been missed if a publication which directly related the old name to the current name was not found. Appendix 4 lists the taxa and synonymous names used in the construction of the MBD. This Appendix is not intended to be a complete listing of all synonymous names; only those names actually encountered during the construction of the MBD are included. 


\section{STATISTICAL PROCEDURES AND MAPPING}

The fossil assemblages were analyzed to examine the climate signals provided by the fossils. Data for RNT were in the form of a categorical variable (presence/absence), rather than as counts of shells; as such it was not usable in some of the statistical analyses employed herein. The shells collected from all other samples were counted so they could be used in the equations that require abundances.

Each gastropod shell counted represents an individual animal. This is not true with bivalves which have two identical shells for each animal. The count of bivalve shells in a given sample was divided in half and the quotient rounded to the nearest whole number. This number was used as the estimated count of bivalves in the sample and was used in all relevant statistical analyses.

Statistical operations were conducted at the species rank except for the Pisidiidae, Succineidae and Physidae. For the purpose of analysis, these families were treated as species unless otherwise noted.

\section{Stasis in Community Structure: Testing $\mathrm{H}_{\mathrm{O} 1}$ via Alpha Diversity Statistics}

The assemblages were analyzed at the alpha diversity level to look for trends in community structure through time. Alpha diversity refers to community structure within a habitat (Magurran, 2004) and was examined via taxonomic richness and dominance.

Taxonomic richness $(S)$ is the count of taxa present in an assemblage (Krebs, 1999; Magurran, 2004; Hammer and Harper, 2006) at a specified taxonomic rank. Richness is usually reported at the species level but any taxonomic rank may be used. Herein, the species rank was used (with the Physidae, Pisidiidae and Succineidae treated as species).

Taxonomic dominance was analyzed using the reciprocal form of Simpson's Index of Dominance (I/D), based on Krebs (1999):

$$
1 / D=1 /\left(\Sigma p_{1}^{2}\right) \quad \text { (Equation 1) }
$$


where $p_{i}$ is the proportion of the $i$-th taxon within its assemblage. This form of Simpson's Index increases in value with increasing taxonomic evenness and ranges from a minimum value of 1 , when a single taxon is present, to $S$ when all taxa are equally common, (Krebs, 1999; Magurran, 2004; Hammer and Harper, 2006). Simpson's Index of Dominance was chosen over the popular Shannon-Weaver/Wiener Index because of the different emphasis the equations place on rare taxa. It is my opinion that rare taxa should receive less consideration when conducting an environmental analysis, due to their transient nature. That is, the rare species are likely accidentally introduced to an assemblage, either ecologically or taphonomicly, and do not likely reflect local environmental conditions. Accordingly, Simpson's Index of Dominance was chosen because it tends to discount rare taxa (Magurran, 2004; Hammer and Harper, 2006).

\section{Stasis in Community Structure: Testing $\mathrm{H}_{\mathrm{ol}}$ via Beta Diversity Statistics}

Beta diversity represents taxonomic similarity between two samples. When these samples are of different historical periods, it is known as turnover (Magurran, 2004). Taxonomic turnover among assemblages was analyzed using the Jaccard Index (Krebs, 1999; Martin and Fairbanks, 1999; Magurran, 2004; Hammer and Harper, 2006). The form of the Jaccard Index used in this study is based on Martin and Fairbanks (1999):

$$
J=a /(a+b+c) \quad \text { (Equation 2) }
$$

where $a$ is the number of taxa common to both compared samples, $b$ is the number of taxa unique to one sample and $c$ is the number of taxa unique to the other sample (Krebs, 1999; Magurran, 2004). The index ranges from a minimum value of 0 , indicating no taxa in common, to 1 where every taxon is in common. When comparing the taxa of samples with unequal richness, the maximum value will never be reached.

\section{Stasis in Community Structure: Testing $\mathrm{H}_{\mathrm{O} 1}$ via Habitat Ratio}

All samples were analyzed to examine the environmental conditions which existed when the fossils were alive. An equation was devised to estimate how wet or dry the environment of southwest Kansas was at various points in history. Every taxon of every sample was identified as being either a 
freshwater or land taxon, based on the opinion of published sources, especially Burch $(1962,1982)$.

Extinct species were identified as either freshwater or land taxa by assigning them to the same category as the extant members of their respective genera. Next, within each assemblage, the number of freshwater taxa $(F)$ and land taxa $(L)$ were independently summed. $F$ and $L$ of each assemblage were then related according to the following equation, called the Habitat Ratio $(\mathrm{Hr})$ :

$$
H r=(L-F) /(L+F) \quad \text { (Equation 3) }
$$

Negative values, where $L<F$, suggests that the environment in which the molluscs lived was tending to be wet, that is a lentic or lotic system or a terrestrial area with abundant meteoric water, at least seasonally, during the segment of history in which the fossil deposit was forming. Thus, all assemblages scoring negative values are defined to be "freshwater" assemblages. Positive values, where $L>F$, suggest drier terrestrial conditions and are defined as "land" assemblages. $H r$ will yield a maximum value of 1 when the assemblage is composed entirely of land taxa and will yield a minimum value of -1 when the assemblage is composed entirely of freshwater taxa. A value of 0 results when $L=F$ and is not clearly assignable to either freshwater or land categories.

\section{Species Composition and Climate: Testing $\mathrm{H}_{\mathrm{O} 2}$ via Biogeography and Climate Variables}

The first step to analyzing molluscan taxa for a climate signal was to employ the MBD and CD in the production of maps. The MBD and CD were joined with an ArcMap ${ }^{\circledR}$ database consisting of a list of all counties in the United States. This joining was necessary because ArcMap's ${ }^{\circledR}$ database contains the relevant spatial information needed by the program to place the information in the MBD and CD on the program's computerized base map of the counties of the United States. For every taxon, a biogeographic range map of the contiguous states was constructed. For taxa also occurring in Alaska and/or Hawaii (and only for those taxa), biogeographic range maps for these states were constructed as well. Maps were also generated for elevation, mean minimum temperature for January, mean maximum temperature for July and mean annual precipitation. The maps can be found in the Climate and Biogeographic Plates section of this study. 
The observed biogeographic ranges are influenced by several nonecological factors: 1) not all states received the same thoroughness in collecting and publishing-some states were more completely studied than others; 2) relevant publications which could have filled in empty regions may exist but were not located for use in this study; 3) taxonomic disagreements among malacologists affected how molluscs are reported in the literature and thus how molluscs are recorded in the MBD;4) any failure to recognize older, now synonymous names in the older literature resulted in molluscs being under-reported in the MBD; and 5) human error in the construction of the MBD. Points 4 and 5 were addressed by being as methodical as possible when collecting and reporting data in the MBD but, for all these reasons, the biogeographic range maps displayed in this study likely display the minimum biogeographic ranges of the taxa and should be regarded as tentative. An additional caution: the larger counties on these maps tend to attract more attention and it is tempting to give them more importance than smaller counties. However, because of the procedures set out in the Methods section, each county represents a single data point, regardless of surface area; thus Yukon-Koyukuk County $\left(377,881 \mathrm{~km}^{2}\right)$, Alaska, Coconino County $\left(48,218 \mathrm{~km}^{2}\right)$, Arizona and Kent County $\left(440 \mathrm{~km}^{2}\right)$, Rhode Island, all display the same amount of information and should be regarded as equivalent units.

The biogeographic range maps produced in this study were constructed by adhering rigorously to the procedures established in the Methods section. It is noted that malacologists currently active are likely to know, from study or personal experience, places where a taxon can be found but which is not recorded herein on a biogeographic range map. For example, Alaska is known to have a rich molluscan fauna (Dall, 1905; Baxter, 1987) but this state is under-represented in this study because few publications could be found which provide location data in a format which could be integrated into the MBD. To address this problem, I am always searching for molluscan publications which contain biogeographic information (of any gastropod species in the United States--snail or slug, land or freshwater, native or exotic) so updated maps can be produced in the future.

The estimated climate tolerances of each taxon of the MBD were derived from the relevant climate and related information contained in the CD. For each taxon, means and ranges were calculated for elevation, temperature and precipitation data from all counties in which a given taxon is known to occur. The range consists of the smallest and largest value of a given climate variable among all the counties in 
which that taxon resides. Mean values for a climate variable were calculated from all the relevant data from every county in which the taxon now resides. A list of all vegetation types occupied by each taxon was also compiled. Means and ranges for the climate and related data were calculated using Microsoft ${ }^{\circledR}$ Excel $^{\otimes}$.

These data were applied to Miller's $(1975,1976)$ four Climate Groups to test for climate differences among them, evaluated as minimum temperature, maximum temperature and annual precipitation. If climate differences can be found, this will suggest that the Climate Groups do reflect the local climate. The four Climate Groups were evaluated by a one-way ANOVA (JMP [SAS Institute Inc., 2003]) to test the hypothesis of no difference among Climate Groups for climate variables. A TukeyKramer HSD parametric test (via JMP) was then conducted to determine where differences exist. Miller $(1975,1976)$ did not accept that the species in Group-IV were suitable for use in climate studies; therefore Group-IV served as a control. Only those Climate Groups that are significantly different from Group-IV provide an ecologically meaningful climate signal.

The fossil molluscan assemblages collected for this study were also analyzed via a one-way ANOVA (via JMP) to test for differences among the assemblages for minimum temperature, maximum temperature and annual precipitation. Tukey-Kramer HSD parametric test (via JMP) followed to determine which assemblages differed for a given climate variable. In this case, the control assemblage was an "assemblage" of 15 randomly selected molluscan species, referred to as the "Random assemblage." The Random assemblage was composed of the following species: Amnicola granum, Cincinnatia cincinnatiensis, Ferrissia fragilis, Fossaria humilis, Fossaria modicella, Gastrocopta cristata, Gastrocopta holzingeri, Gyraulus circumstriatus, Gyraulus parvus, Hawaiia minuscula, Helicodiscus singleyanus, Pupilla blandi, Pupilla muscorum, Strobilops labyrinthicus and Zonitoides arboreus. Only those assemblages which were significantly different from the Random assemblage would provide ecologically meaningful climate information.

\section{Species Composition and Climate: Testing $\mathrm{H}_{\mathbf{O} 2}$ via Multivariate Statistics}

The hypothesis that molluscan species and climate variables are associated was also examined via multivariate statistics. I used a distance-based ordination method, nonmetric multidimensional scaling 
(NMS, using PC-ORD [McCune and Mefford, 2006]), to look for groups of counties and molluscan taxa which have climate significance. This ordination method minimizes the stress ("stress" here meaning the measure of the poorness of fit between the ordination outcome and measured ecological distances).

Two large data matrices were created, the first matrix with 2486 rows of counties and 62 columns of presence/absence data of molluscan taxa, and the second matrix with 2486 rows of counties and 3 columns of climate variables (minimum temperature, maximum temperature and precipitation). A subsequent matrix of all pairwise Euclidean distances among samples was generated; the distance measure used was Sørensen (Bray-Curtis). Ordination was then conducted on this final matrix, with six dimensions chosen.

NMS was run slowly and thoroughly in autopilot mode. The program ran 250 runs of real data and 250 runs of randomized data. A three-dimensional solution was recommended by the outcome. The stability criterion was 0.00001 , with 15 iterations to evaluate stability. Maximum number of iterations was 500. Starting coordinates were randomly generated and the step length was 0.20 . 


\section{RESULTS}

Appendix 5 displays the taxa found in every assemblage examined in this study and includes the number of shells collected for each taxon within each assemblage. Application of the statistical procedures mentioned in the Statistical Procedures and Mapping section to this raw data yields the data displayed in Table 5.

Table 5. Molluscan Diversity. Data for Meade Basin molluscan assemblages, derived from the raw data of Appendix 5. S-taxonomic richness, $\mathrm{Hr}$-habitat ratio, $/ / D$-Simpson's dominance, $J$-Jaccard Index showing every assemblage compared to RNT, asterisk $\left({ }^{*}\right)$ - no data.

\begin{tabular}{cccccc}
\hline ASSEMBLAGE SYMBOL & AGE (Ma) & $S$ & $H r$ & $l / D$ & $J$ \\
\hline RNT & 0 & 20 & 0 & $*$ & 1.00 \\
RTB & 0.011 & 24 & 0.67 & 8.67 & 0.29 \\
RTA & 0.012 & 22 & 0.45 & 9.66 & 0.31 \\
BDL & 0.013 & 16 & 0.38 & 2.77 & 0.29 \\
CL2 & 0.014 & 12 & 0.67 & 2.80 & 0.19 \\
CL1 & 0.020 & 13 & 0.54 & 5.69 & 0.18 \\
BD2 & 0.030 & 9 & 0.56 & 1.98 & 0.21 \\
JQB & 0.141 & 15 & 0.20 & 8.62 & 0.35 \\
JQA & 0.142 & 24 & 0.17 & 7.60 & 0.38 \\
M35 & 0.250 & 8 & -0.25 & 1.73 & 0.27 \\
SPB & 0.301 & 9 & 0.11 & 1.53 & 0.21 \\
SPA & 0.302 & 7 & 0.71 & 1.40 & 0.23 \\
CR7 & 0.600 & 19 & -0.05 & 3.15 & 0.39 \\
CO3B & 0.640 & 30 & 0.20 & 4.92 & 0.35 \\
CO3A & 0.711 & 17 & 0.65 & 7.79 & 0.19 \\
CH4 & 0.712 & 16 & 0.75 & 3.96 & 0.20 \\
CHY & 0.713 & 29 & 0.59 & 4.67 & 0.20 \\
PMA & 2.810 & 19 & 0.16 & 2.26 & 0.34 \\
B1B & 3.280 & 11 & 0.64 & 2.47 & 0.29 \\
X1E & 3.881 & 13 & 1.00 & 7.16 & 0.18 \\
X2B & 3.882 & 13 & 0.54 & 2.05 & 0.38 \\
R1A & 3.883 & 9 & -0.11 & 2.79 & 0.26 \\
RYA & 3.884 & 7 & 0.14 & 2.31 & 0.23 \\
RFX & 4.140 & 9 & -0.11 & 2.79 & 0.26 \\
TFC & 4.390 & 9 & 0.11 & 2.12 & 0.26 \\
FAL & 4.711 & 7 & -0.43 & 2.48 & 0.17 \\
AGO & 4.712 & 7 & 0.71 & 4.05 & 0.17 \\
\hline & & & & &
\end{tabular}


Graphs generated from the data in Table 5 show a gap in data points from approximately $2.5 \mathrm{Ma}$ to 1.0Ma. This gap is produced because there are no mollusc-bearing strata dating from this time available for study in the Meade area.

\section{Alpha Diversity}

As shown in Figures 2, and 3, alpha diversity measures (taxonomic richness and dominance) revealed that considerable difference among assemblages existed, thus the hypothesis of stasis $\left(\mathrm{H}_{\mathrm{OI}}\right)$ is falsified. There was a slight trend of increased richness through time with a peak approximately $0.64 \mathrm{Ma}$ (CO3B, $S=30)$, and a subsequent decrease through time to the present day. This trend was very weak $\left(\mathrm{r}^{2}=\right.$ 0.237); there was a large amount of variation in richness among assemblages. Fossil assemblages closely temporally spaced show this variation; for example, assemblages RYA through XlE were similar in age $(3.88 \mathrm{Ma})$ but showed a richness range of 7 to 13 taxa. Collectively, all the assemblages younger than 1.0Ma show a richness range from 7 to 30 taxa.

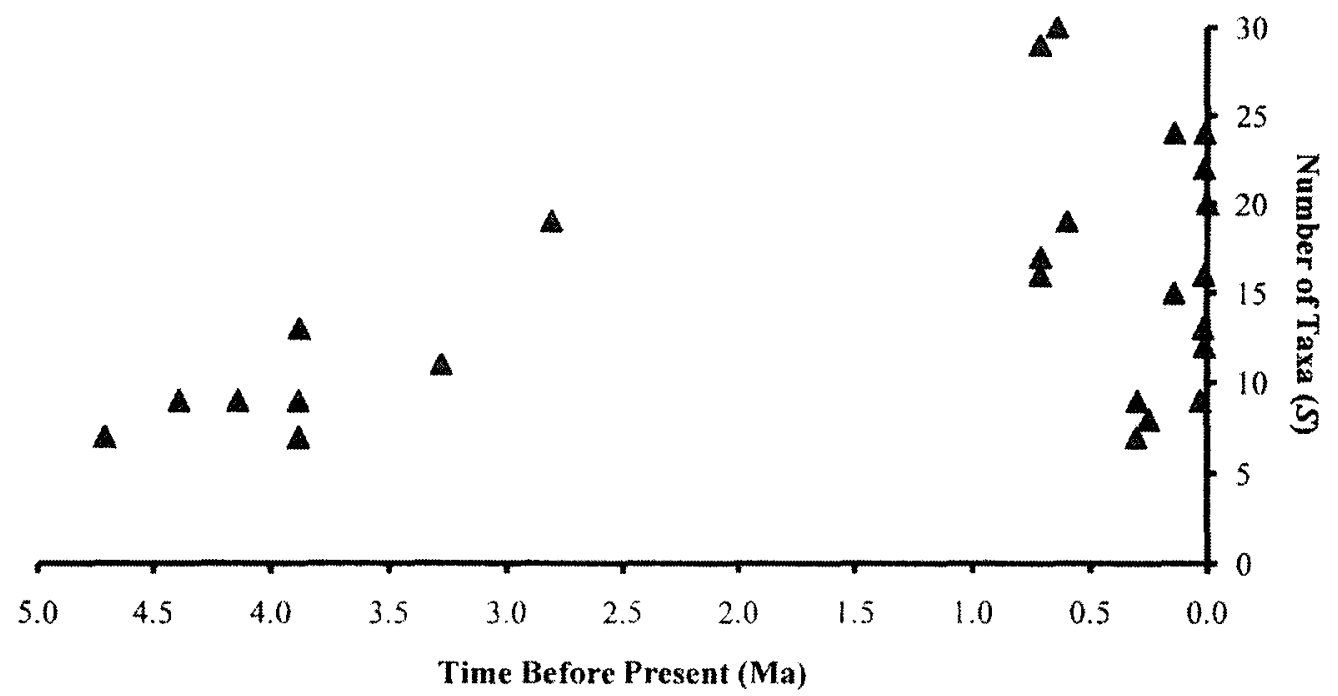

Figure 2. Taxonomic Richness Through Time. Taxonomic level is species except for the following included taxa: Physidae, Succineidae and Pisidiidae. Raw data for this graph are given in Table $5 . \mathrm{r}^{2}=$ 0.237 .

Taxonomic dominance does not display either stasis through time (therefore $\mathrm{H}_{\mathrm{OI}}$ is falsified) or 
any sense of gradual modernization (Figure 3). Even closely temporally-spaced fossil assemblages fluctuated in dominance, which is reflected in the low $r^{2}$ value $\left(r^{2}=0.113\right)$. The values for all the assemblages are relatively low. Given that dominance values could be as high as the taxonomic richness for that assemblage, the low values indicate that most assemblages are composed of one or a few abundant taxa and several rarer ones. The assemblage AGO displays the least amount of dominance $(4.71 \mathrm{Ma}, 1 / D=$ 4.05), compared to its richness $(S=7)$, indicating a more equal distribution of individuals among taxa occurred within this assemblage.

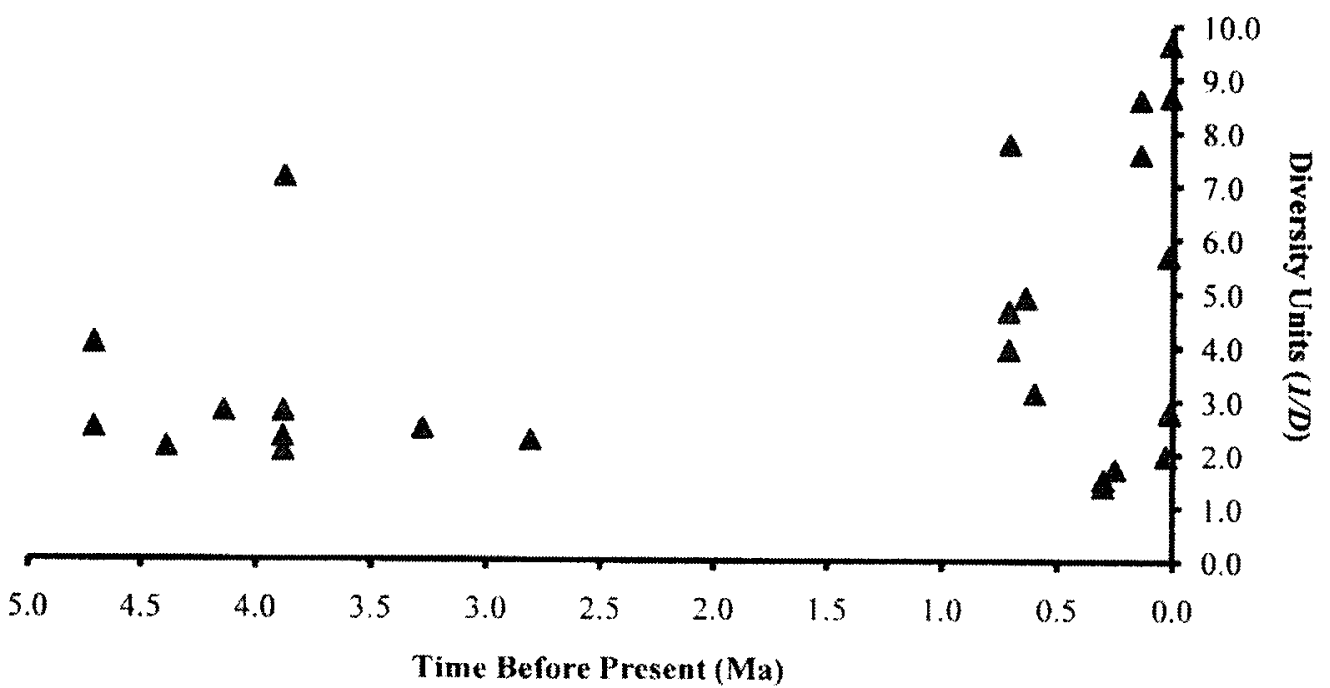

Figure 3. Taxonomic Dominance Through Time. Taxonomic level is species except for the following included taxa: Physidae, Succineidae and Pisidiidae. Raw data for this graph are given in Table 5. $\mathrm{r}^{2}=$ 0.113 .

\section{Beta Diversity}

The results for beta diversity are given in Table 5. The Jaccard Index column displays data derived by comparing each assemblage to RNT. When compared with itself, RNT yields a value of 1.00 , the maximum value possible. These results are graphed in Figure 4. Appendix 6 gives Jaccard Index values for all possible combinations of assemblages.

As was seen for both richness and dominance, beta diversity displayed neither stasis $\left(\mathrm{H}_{\mathrm{O}}\right.$ rejected $)$ nor gradual modernization through time. As observed with the alpha diversity metrics, turnover shows a wide variation in values, even among assemblages which are closely temporally spaced. For example, 
assemblages RYA through X1E range from 0.18 to 0.38 , which is nearly equivalent to the total range of turnover values displayed in Figure 4. This variation in values is reflected in the low values for $r^{2}\left(r^{2}=\right.$ 0.024). Overall, turnover values were very low, as can be seen from Appendix 6, indicating little taxonomic similarity among assemblages: the greatest similarity was seen between RFX/R1A $(J=0.64)$ while the least similarity is between $\mathrm{SPB} / \mathrm{JQB}(J=0.04)$. It should be noted that most of the taxa observed as fossils are still extant in the United States, thus changes in turnover are not due to the origination of new species. Also, only four fossil species are extinct, so extinction is similarly not an important factor in the beta diversity patterns observed in this study. Changes in turnover are best interpreted as changes in the biogeographic ranges of the individual taxa within each assemblage.

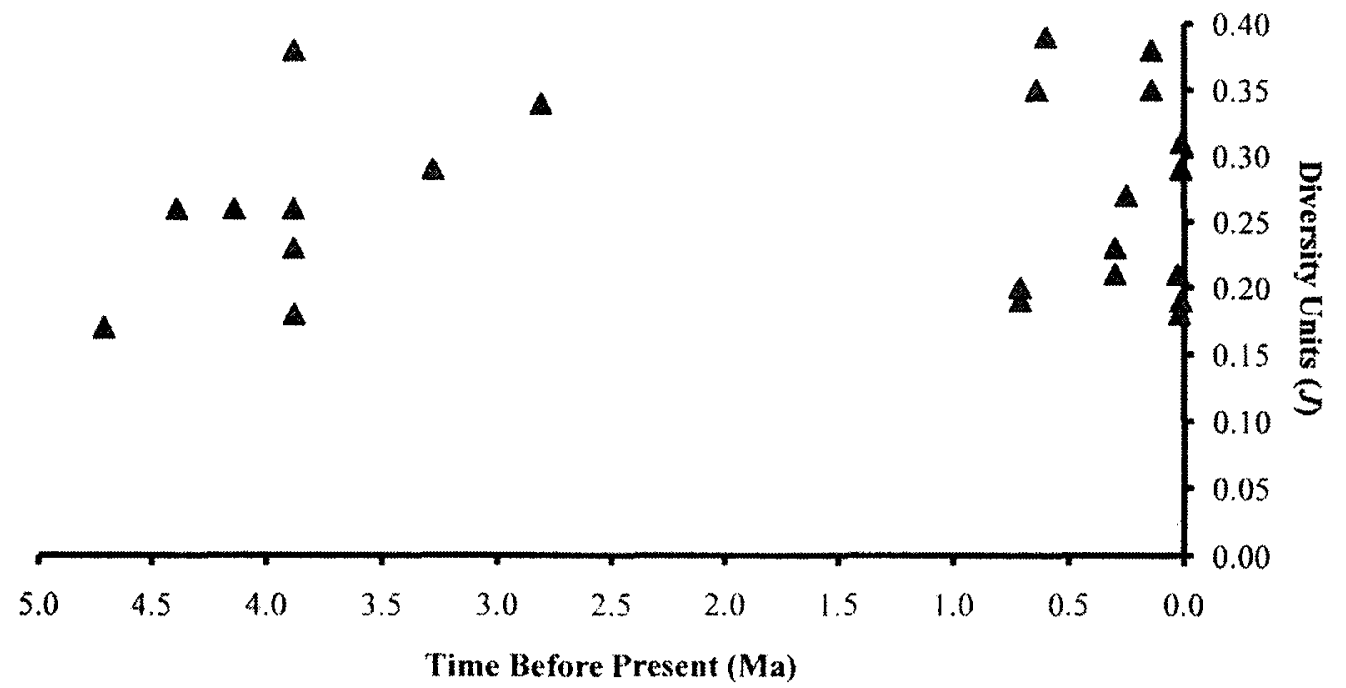

Figure 4. Taxonomic Turnover Through Time. RNT is compared with every assemblage except itself. Taxonomic level is species except for the following included taxa: Physidae, Succineidae and Pisidiidae. Raw data for this graph are given in Table $5 . r^{2}=0.024$.

\section{The Habitat Ratio}

Figure 5 provides the Habitat Ratio for the Meade Basin fossil assemblages. According to this metric, assemblages FAL, RFX, R1A, CR7 and M35 are all freshwater assemblages. RNT, with a value of 0, indicates a 50:50 ratio of freshwater to land taxa. As such, RNT could just as easily be defined as a freshwater assemblage as a land assemblage. All other assemblages are land assemblages with X1E scoring a value of 1.00 , indicating there were no freshwater taxa in this assemblage. 
The fact that the proportions of freshwater and land taxa changed throughout the five million years of this study is further evidence refuting $\mathrm{H}_{\mathrm{O}}$, although no overall habitat progression was observed. As with the alpha and beta diversity statistics, the Habitat Ratio displays a large amount of variation, even among closely spaced assemblages: $\mathrm{AGO}$ and FAL are close in age (4.71Ma) but score 0.71 and -0.43 , respectively, by the Habitat Ratio. These values indicate that although deposited nearly concurrently, AGO and FAL habitats were very different. The Habitat Ratio fails to identify as freshwater, those assemblages with bivalves. Bivalves can be found in RNT, RTB, RTA, BDL, CL1, JQB, JQA, M35, CR7, CO3B, CHY and PMA, but of these assemblages only CR7 and M35 were identified as freshwater assemblages.

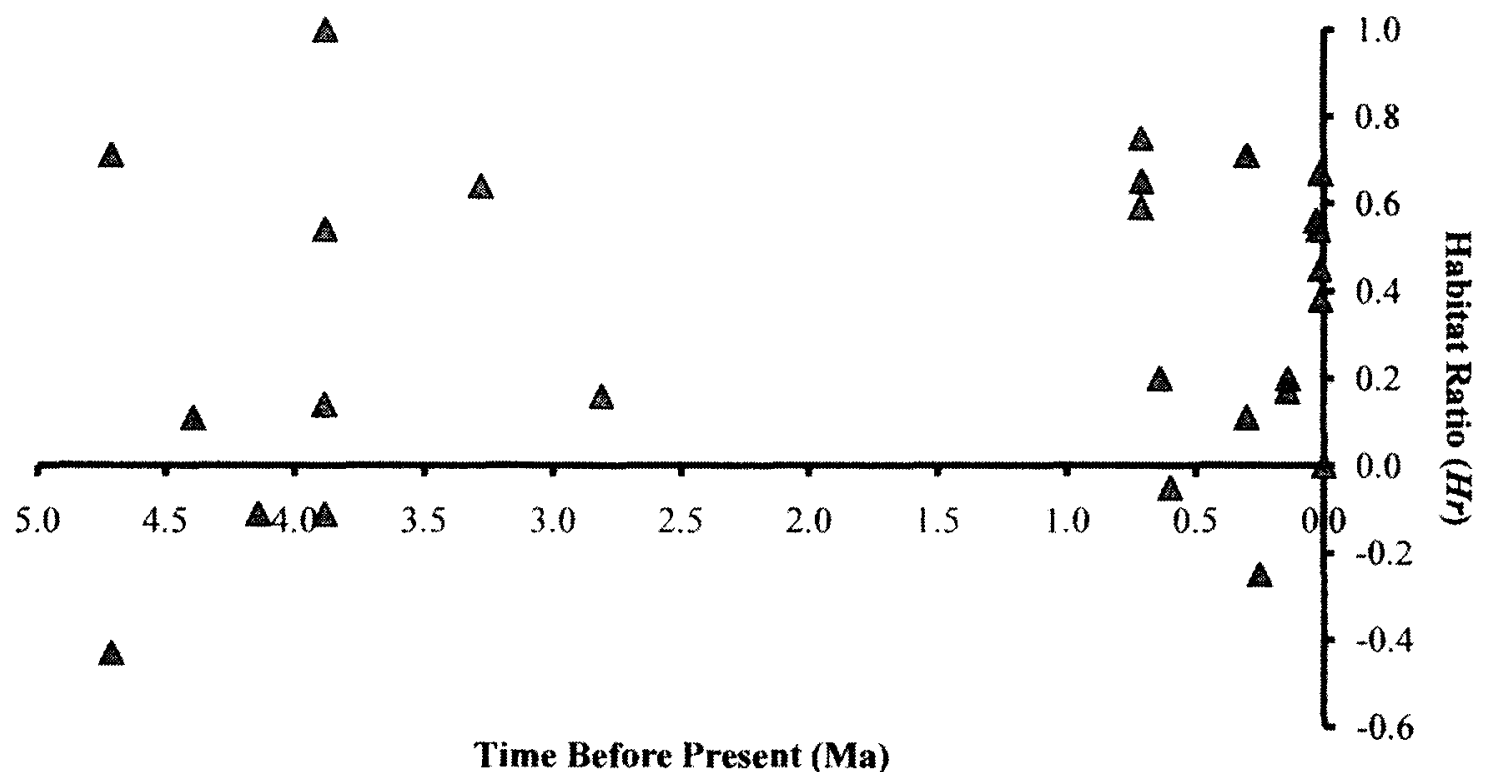

Figure 5. Molluscan Habitat Ratio. Raw data for this graph are given in Table 5. Assemblages scoring negatively are freshwater assemblages; assemblages scoring positively are land assemblages. $r^{2}=0.029$.

\section{Mapping Biogeography and Climate Variables}

Appendix 7 summarizes climatic variables that each taxon exists under; this appendix is a combination of data contained in both the CD and MBD. To calculate means and ranges, every county in which a given taxon was known to occur (from the MBD) was used and no weighting technique was applied. The value for means and ranges of elevation, temperature and precipitation, as well as the list of vegetation types, constitutes the estimated range of environmental conditions that each taxon can tolerate. 
It must be noted that although the molluscs can be found in counties having the values displayed in Appendix 7 and thus "live" under these climate conditions, molluscs may not necessarily be active and may hibernate or aestivate through the harsher conditions. For example, Deroceras laeve occurs in North Slope County, Alaska, where it can reach a January temperature of $-31^{\circ} \mathrm{C}$; it is unlikely that this slug is actually active at this temperature. Also, the temperature data reported in the $\mathrm{CD}$ is air temperature, not water temperature. Freshwater molluscan taxa do not experience temperatures as low as $-31^{\circ} \mathrm{C}$, unless they are hibernating in the muddy bottom of a completely frozen aquatic system. Generally, freshwater molluscs live in aquatic systems that do not completely freeze, and thus live under the ice in a layer of water warmer than $0^{\circ} \mathrm{C}$, irrespective of air temperature. Therefore temperature data in the $\mathrm{CD}$ does not pertain to the freshwater taxa in the same way they do for land taxa. Similar relationships hold for precipitation data; freshwater taxa are always found under water, so the amount of precipitation a county receives is not relevant to them, with the exception of those individuals that live in aquatic systems prone to desiccation. Although the biogeographic data in the MBD are incomplete, additional records, while changing the appearance of the biogeographic maps, would little change the means and ranges of climate variables.

One of the primary assumptions for this study is that molluscs can be used for interpreting climate patterns. To do this, molluscan biogeography must be limited by climate. This assumption was tested in a variety of ways including applying the climate tolerances of Appendix 7 to Miller's (1975, 1976) Climate Groups, applying climate tolerances to the fossil assemblages collected for this study and through ordination statistics based on tolerances among extant animals. As noted in the Introduction, the criteria which Miller $(1975,1976)$ relied upon to place species into his Climate Groups were not provided in his two studies, and membership in a Group is ". . .admittedly somewhat arbitrary since some species are not clearly assignable to one group (Miller, 1975, p. 14)." However, the biogeographic range maps and data herein can be compared to Miller's $(1975,1976)$ verbal descriptions of climate restrictions to infer reliability of the Climate Group method.

When examining the biogeographic range maps produced for this study, it is important to keep in mind that these ranges are likely the minimum ranges for the various taxa, due to the way the MBD was constructed (see Methods). In discussing the distribution of molluscan species, it will often be convenient to refer to sections of the country, rather than to individual states. In these cases, the regional subdivisions 
of Ginsburg et al. (1983) will be used as a standard, with reasonable modifications (see Table 6).

Table 6. Divisions of the United States. Regional subdivisions of the United States following Ginsburg et al. (1983) with modifications.

\begin{tabular}{|c|c|}
\hline $\begin{array}{l}\text { REGIONAL } \\
\text { SUBDIVISION }\end{array}$ & INCLUDED STATES \\
\hline Contiguous Pacific States & California, Oregon, Washington \\
\hline Midwest States & $\begin{array}{l}\text { Illinois, Indiana, lowa, Kansas, Michigan, Minnesota, } \\
\text { Missouri, Nebraska, North Dakota, Ohio, South Dakota, } \\
\text { Wisconsin }\end{array}$ \\
\hline Mountain States & Colorado, Idaho, Montana, Nevada, Utah, Wyoming \\
\hline $\begin{array}{l}\text { Noncontiguous Pacific } \\
\text { States }\end{array}$ & Alaska, Hawaii \\
\hline Northeast States & $\begin{array}{l}\text { Connecticut, Maine, Massachusetts, New Hampshire, New } \\
\text { Jersey, New York, Pennsylvania, Rhode Island, Vermont }\end{array}$ \\
\hline Southeast States & $\begin{array}{c}\text { Alabama, Arkansas, Delaware, District of Columbia, } \\
\text { Florida, Georgia, Kentucky, Louisiana, Maryland, } \\
\text { Mississippi, North Carolina, South Carolina, Tennessee, } \\
\text { Virginia, West Virginia }\end{array}$ \\
\hline Southwest States & Arizona, New Mexico, Oklahoma, Texas \\
\hline
\end{tabular}

Miller (1976) considered Cionella lubrica, Discus whitneyi, Gastrocopta holzingeri, Gyraulus circumstriatus, Gyraulus deflectus, Nesovitrea electrina, Promenetus exacuous, Punctum minutissimum, Pupilla blandi, Pupilla muscorum, Stagnicola exilis, Strobilops labyrinthicus, Vallonia cyclophorella, Vallonia gracilicosta, Vallonia pulchella, Valvata tricarinata and Vertigo elatior to be Group-I speciesnorthern species, limited in their southern distribution by high temperatures (other species were also placed in Climate Group-I but only those in common with this study are listed above). Of the species on this list, only $S$. exilis could truly be called a northern species, as it occurs exclusively in Midwest States north of the Missouri and Ohio Rivers. The biogeographic ranges of the other species are more variable. Valvata tricarinata and $G$. deflectus both are mostly northern in distribution but both have rare occurrences scattered south of the Missouri and Ohio Rivers into the Southwest, Southeast and Mountain States. Strobilops labyrinthicus occurs in almost every state of the Midwest, Northeast and Southwest States, with additional occurrences in Oklahoma, Texas and Wyoming. Gastrocopta holzingeri and V. gracilicosta are both poorly represented in the Northeast States. Vallonia gracilicosta is also poorly represented in the Midwest States but is better represented in the Mountain and Southwest States while, G. holzingeri is best 
represented among the Midwest and Southwest States. Vallonia cyclophorella and P. blandi could both be best described as western species, as both are very prevalent in the Mountain States and into the Southwest States and, for V. cyclophorella, the Contiguous Pacific States as well. The remaining species of this list are very widely distributed in the east-west direction; all except $P$. muscorum and $V$. elatior can be found in both California and the Northeast States. Discus whitneyi occurs in southern Alaska-the only species on this list which does so. These remaining species (D. whitneyi, N. electrina, C. lubrica, P. exacuous, G. circumstriatus, $P$. minutissimum, $V$. pulchella, $V$. elatior and $P$. muscorum) usually tend to be heavily concentrated in Midwest and Northeast States - generally north of the Missouri and Ohio Rivers-and again in the Mountain and Southwest States. No species in this list occurs in Hawaii.

All of these species except $S$. exilis are very broadly distributed outside of what would usually be recognized as northern states. However, it could be argued, as Miller (1975) does, that those occurrences west of the Great Plains are in high elevation areas having a climate similar to actual northern states. To (informally) evaluate this assertion, data from six counties within the biogeographic range of $D$. whitneyi were taken from the CD: three counties regarded as "mountainous" and three regarded as "northern" (Table 7).

Table 7. County Summary for Group-1. Selected mountainous and northern counties within the biogeographic range of Discus whitneyi. Ref City-reference city, Lat-latitude, Long--longitude, Elevtn-elevation, MinT_-mean minimum temperature for January, MaxT-mean maximum temperature for July, Precip—-mean annual precipitation.

\begin{tabular}{l|ccc|ccc}
\hline ATTRIBUTE & \multicolumn{2}{|c|}{ MOUNTAINOUS COUNTIES } & \multicolumn{3}{c}{ NORTHERN COUNTIES } \\
\hline State & Montana & Wyoming & New Mexico & Michigan & Minnesota & Maine \\
County & Beaverhead & Albany & Taos & St. Joseph & Cook & Kennebec \\
Ref City & Jackson & Laramie & Red River & Three Rivers & Grand Portage & Augusta \\
Lat (N) & $45^{\circ} 22^{\prime} 05^{\prime \prime}$ & $41^{\circ} 18^{\prime} 41^{\prime \prime}$ & $36^{\circ} 42^{\prime} 29^{\prime \prime}$ & $41^{\circ} 56^{\prime} 38^{\prime \prime}$ & $47^{\circ} 57^{\prime} 50^{\prime \prime}$ & $44^{\circ} 18^{\prime} 38^{\prime \prime}$ \\
Long (W) & $113^{\circ} 24^{\prime} 32^{\prime \prime}$ & $105^{\circ} 35^{\prime} 28^{\prime \prime}$ & $105^{\circ} 24^{\prime} 20^{\prime \prime}$ & $85^{\circ} 37^{\prime} 57^{\prime \prime}$ & $89^{\circ} 41^{\prime} 05^{\prime \prime}$ & $69^{\circ} 46^{\prime} 46^{\prime \prime}$ \\
Elevtn (m) & 1974 & 2185 & 2637 & 245 & 191 & 38 \\
MinT $\left({ }^{\circ} \mathrm{C}\right)$ & -18 & -14 & -17 & -7 & -16 & -12 \\
MaxT $\left({ }^{\circ} \mathrm{C}\right)$ & 27 & 26 & 26 & 31 & 22 & 27 \\
Precip $(\mathrm{cm})$ & 33 & 25 & 41 & 91 & 63 & 107 \\
Vegetation & M3112 & M3113 & M3113 & 2212 & 2111 & 2114 \\
\hline
\end{tabular}

The counties in Table 7 were chosen via judgmental sampling (Krebs, 1999) but if they can be regarded as typical for their respective groups, then some generalizations can be made. Northern counties appear to be slightly warmer $\left(-16^{\circ} \mathrm{C}\right.$ to $\left.31^{\circ} \mathrm{C}\right)$ than mountainous counties $\left(-18^{\circ} \mathrm{C}\right.$ to $\left.27^{\circ} \mathrm{C}\right)$ but there is 
enough overlap to lend support to Miller's (1975) assertion that the two groups are thermally equivalent. However, it is important not to push the similarity between mountainous and northern regions too far. As can be seen from Table 7, northern counties are much wetter than mountain counties, while mountain counties are higher in elevation than northern counties.

Table 8 displays the climate tolerances for the Group-I species in common between Miller (1976) and this study (from Appendix 7). The "Grand Values" ("Grand Ranges" and "Grand Means") displayed at the bottom of Table 8 are a summary of this data: the lowest minimum value and highest maximum value for minimum/maximum temperature and precipitation are listed as the Grand Ranges for Climate Group-I. All of the means for the included taxa were used to calculate the Grand Means for the Group. Together, the Grand Values represents the estimated climate of southwest Kansas that fossil members of Group-I species lived under when they were alive. As can be seen, the estimated climate tolerance of individual species is similar from one species to the next. 
Table 8. Group-I Climate. Summary of the environmental tolerances for Group-I species of Miller (1975, 1976) and this study. Species names are abbreviated see Appendix 3 for the full names. MinT-mean minimum temperature for January, Max T - mean maximum temperature for July, PRECIP — mean annual precipitation, $\mathrm{R}-$ range displayed using the format "smallest value;largest value", $\mathbf{M}-$ mean value. Grand Values are the estimated climate for this group.

\begin{tabular}{c|cc|cc|cc}
\hline TAXA & \multicolumn{2}{|c|}{$\operatorname{MinT}\left({ }^{\circ} \mathrm{C}\right)$} & \multicolumn{2}{|c|}{$\operatorname{MaxT}\left({ }^{\circ} \mathrm{C}\right)$} & \multicolumn{2}{|c}{ PRECIP $(\mathrm{cm})$} \\
& $\mathrm{R}$ & $\mathbf{M}$ & $\mathrm{R}$ & $\mathbf{M}$ & $\mathrm{R}$ & $\mathbf{M}$ \\
\hline C. lubrica & $-24 ; 6$ & $\mathbf{- 8}$ & $21 ; 39$ & $\mathbf{2 9}$ & $5 ; 147$ & $\mathbf{8 7}$ \\
D. whitneyi & $-24 ; 3$ & $\mathbf{- 9}$ & $12 ; 39$ & $\mathbf{2 9}$ & $5 ; 274$ & $\mathbf{8 3}$ \\
G. holzingeri & $-24 ; 4$ & $\mathbf{- 9}$ & $24 ; 38$ & $\mathbf{3 2}$ & $25 ; 147$ & $\mathbf{7 8}$ \\
G. circumstriatus & $-24 ; 8$ & $\mathbf{- 1 2}$ & $22 ; 39$ & $\mathbf{3 0}$ & $5 ; 112$ & $\mathbf{5 7}$ \\
G. deflectus & $-24 ; 3$ & $\mathbf{- 1 0}$ & $24 ; 36$ & $\mathbf{2 9}$ & $38 ; 127$ & $\mathbf{9 0}$ \\
N. electrina & $-24 ; 1$ & $\mathbf{- 9}$ & $21 ; 38$ & $\mathbf{2 9}$ & $15 ; 213$ & $\mathbf{9 0}$ \\
P. exacuous & $-24 ;-1$ & $\mathbf{- 1 2}$ & $25 ; 36$ & $\mathbf{2 9}$ & $25 ; 127$ & $\mathbf{8 0}$ \\
P. minutissimum & $-24 ; 11$ & $\mathbf{- 5}$ & $21 ; 37$ & $\mathbf{3 0}$ & $25 ; 168$ & $\mathbf{1 0 0}$ \\
P. blandi & $-22 ;-1$ & $\mathbf{- 1 1}$ & $22 ; 38$ & $\mathbf{3 0}$ & $15 ; 96$ & $\mathbf{4 0}$ \\
P. muscorum & $-23 ; 1$ & $\mathbf{- 1 0}$ & $22 ; 37$ & $\mathbf{2 9}$ & $15 ; 127$ & $\mathbf{7 2}$ \\
S. exilis & $-24 ;-7$ & $\mathbf{- 1 4}$ & $26 ; 32$ & $\mathbf{2 9}$ & $53 ; 96$ & $\mathbf{7 6}$ \\
S. labyrinthicus & $-24 ; 16$ & $\mathbf{- 5}$ & $21 ; 37$ & $\mathbf{3 1}$ & $28 ; 168$ & $\mathbf{1 0 2}$ \\
V. cyclophorella & $\mathbf{- 2 2 ; 3}$ & $\mathbf{- 1 0}$ & $23 ; 39$ & $\mathbf{3 0}$ & $5 ; 84$ & $\mathbf{3 8}$ \\
V. gracilicosta & $-24 ;-1$ & $\mathbf{- 1 1}$ & $24 ; 38$ & $\mathbf{3 1}$ & $15 ; 112$ & $\mathbf{4 9}$ \\
V. pulchella & $-24 ; 9$ & $\mathbf{- 8}$ & $21 ; 39$ & $\mathbf{3 0}$ & $5 ; 183$ & $\mathbf{8 6}$ \\
V. tricarinata & $-24 ; 3$ & $\mathbf{- 1 2}$ & $25 ; 36$ & $\mathbf{2 9}$ & $33 ; 137$ & $\mathbf{8 0}$ \\
V. elatior & $-24 ;-3$ & $\mathbf{- 1 2}$ & $24 ; 37$ & $\mathbf{2 9}$ & $15 ; 122$ & $\mathbf{7 8}$ \\
Grand Values & $-24 ; 16$ & $\mathbf{- 1 0}$ & $12 ; 39$ & $\mathbf{3 0}$ & $5 ; 274$ & $\mathbf{7 6}$ \\
\hline
\end{tabular}

Miller's (1976) Group-II species represented in this study are: Gastrocopta cristata, Gastrocopta pellucida, Gastrocopta procera, Helicodiscus singleyanus and Vallonia perspectiva. These species are identified by Miller (1976) as southern species, limited by cold winter temperatures. All of the species in this list can be found concentrated in Southwest States, with greater or lesser expansions into other sections of the country. None of the species on this list occur in Alaska or Hawaii. The "most southern" species on this list is G. pellucida, which has nearly all of its occurrences south of a line coincident with the northern boundaries of Arizona, New Mexico and Oklahoma (lat 37 $00^{\prime} \mathrm{N}$. [Rand Mc.Nally, 2009c]), drawn coastto-coast. This species can be found from southern California to North Carolina, with a few, isolated, occurrences farther north. Gastrocopta cristata, H. singleyanus and $V$. perspectiva can all be found concentrated in Southwest States, with a smaller concentration in mainland Virginia, Maryland and the Delmarva Peninsula. All three of these species can be found in scattered occurrences in the Midwest and Southeast States, with $V$. perspectiva showing a concentration in the northern Minnesota and the Dakotas. Gastrocopta procera is more unusual in that it is very broadly distributed among the Midwest, Southwest 
and Southeast States, and occurs as far northeast as Long Island. For the species occurring on this list, the concentration of occurrences among the Southwest States, fit with a southern designation for these species, but the occurrences elsewhere do not, especially for $V$. perspectiva and $G$. procera whose distributions are highly atypical for the Group. Species occurrences along the Atlantic Coast are thought to be due to the moderating effect the Atlantic Ocean has on temperatures along the coast (Miller, 1975). Miller (1975) seems to be suggesting that "coastal" counties have a similar climate to "southern" counties. To (informally) examine this suggestion, climate data for six counties which occur within the biogeographic range of $G$. cristata were taken from the $C D$ : three counties regarded as southern and three as coastal (Table 9).

Table 9. County Summary for Group-II. Selected southern and coastal counties within the biogeographic range of Gastrocopta cristata. Ref City - reference city, Lat-latitude, Long - longitude, Elevtnelevation, MinT - mean minimum temperature for January, MaxT - mean maximum temperature for July, Precip-mean annual precipitation.

\begin{tabular}{l|ccc|ccc}
\hline ATTRIBUTE & \multicolumn{3}{|c|}{ SOUTHERN COUNTIES } & \multicolumn{3}{c}{ COASTAL COUNTIES } \\
\hline State & New Mexico & Texas & Texas & Delaware & Maryland & Virginia \\
County & Luna & Brewster & Hidalgo & New Castle & Worcester & Northampton \\
Ref City & Deming & Terlingua & Weslaco & Wilmington & Snow Hill & Nassawadox \\
Lat $(\mathrm{N})$ & $32^{\circ} 16^{\prime} 07^{\prime \prime}$ & $29^{\circ} 19^{\prime} 18^{\prime \prime}$ & $26^{\circ} 09^{\prime} 34^{\prime \prime}$ & $39^{\circ} 44^{\prime} 45^{\prime \prime}$ & $38^{\circ} 10^{\prime} 37^{\prime \prime}$ & $37^{\circ} 28^{\prime} 29^{\prime \prime}$ \\
Long (W) & $107^{\circ} 45^{\prime} 29^{\prime \prime}$ & $103^{\circ} 36^{\prime} 58^{\prime \prime}$ & $97^{\circ} 59^{\prime} 27^{\prime \prime}$ & $75^{\circ} 32^{\prime} 49^{\prime \prime}$ & $75^{\circ} 23^{\prime} 34^{\prime \prime}$ & $75^{\circ} 51^{\prime} 30^{\prime \prime}$ \\
Elevtn $(\mathrm{m})$ & 1322 & 884 & 24 & 30 & 4 & 11 \\
MinT $\left({ }^{\circ} \mathrm{C}\right)$ & -3 & 2 & 11 & 1 & -2 & 1 \\
MaxT $\left({ }^{\circ} \mathrm{C}\right)$ & 34 & 33 & 36 & 24 & 31 & 31 \\
Precip $(\mathrm{cm})$ & 25 & 33 & 61 & 114 & 127 & 107 \\
Vegetation & 3211 & 3212 & 2523 & 2214 & 2320 & 2320 \\
\hline
\end{tabular}

The counties in Table 9 were chosen via judgmental sampling (Krebs, 1999) but if they can be regarded as typical for their respective groups, then some generalizations can be made. Elevation differs between the two groups with coastal counties lower in elevation than southern counties. Coastal counties are much wetter than southern counties. However, it is temperature again which is relevant to Miller's (1975) Group-II concept. Southern counties appear warmer $\left(-3^{\circ} \mathrm{C}\right.$ to $\left.36^{\circ} \mathrm{C}\right)$ than coastal counties $\left(-2^{\circ} \mathrm{C}\right.$ to $31^{\circ} \mathrm{C}$ ) but this difference is not great and may be similar enough to lend support to Miller's (1975) suggestion that species occurrences along the Atlantic Coast may well experience similar temperatures to southern counties.

Table 10, a listing of Miller's (1976) Group-II species, is similar to Table 8 in construction and 
purpose. There is greater variation in climate variables within this table, but when comparing the Grand Values for Table 10 with the Grand Values in Table 8 , it can be seen that there is very little difference between them. The means suggest that Group-II climate is somewhat warmer and wetter than Group-I, but this difference is slight.

Table 10. Group-II Climate. Summary of the environmental tolerances for Group-II species of Miller $(1975,1976)$ and this study. Species names are abbreviated see Appendix 3 for the full names. MinTmean minimum temperature for January, MaxT - mean maximum temperature for July, PRECIP-mean annual precipitation, $\mathbf{R}-$ range displayed using the format "smallest value;largest value", $\mathbf{M}--$ mean value. Grand Values are the estimated climate for this group.

\begin{tabular}{c|cc|cc|cc}
\hline \multirow{2}{*}{ TAXA } & \multicolumn{2}{|c|}{$\operatorname{MinT}\left({ }^{\circ} \mathrm{C}\right)$} & \multicolumn{2}{|c|}{$\operatorname{MaxT}\left({ }^{\circ} \mathrm{C}\right)$} & \multicolumn{2}{|c}{ PRECIP $(\mathrm{cm})$} \\
& $\mathrm{R}$ & $\mathbf{M}$ & $\mathrm{R}$ & $\mathbf{M}$ & $\mathrm{R}$ & $\mathbf{M}$ \\
\hline G. cristata & $-10 ; 11$ & $\mathbf{- 2}$ & $24 ; 38$ & $\mathbf{3 4}$ & $15 ; 127$ & $\mathbf{7 4}$ \\
G. pellucida & $-14 ; 16$ & $\mathbf{1}$ & $27 ; 41$ & $\mathbf{3 4}$ & $5 ; 168$ & $\mathbf{8 2}$ \\
G. procera & $-16 ; 11$ & $\mathbf{- 3}$ & $26 ; 38$ & $\mathbf{3 3}$ & $18 ; 168$ & $\mathbf{9 1}$ \\
H. singleyanus & $-16 ; 11$ & $\mathbf{- 3}$ & $24 ; 38$ & $\mathbf{3 3}$ & $15 ; 152$ & $\mathbf{8 2}$ \\
V. perspectiva & $-23 ; 3$ & $\mathbf{- 9}$ & $27 ; 38$ & $\mathbf{3 1}$ & $15 ; 147$ & $\mathbf{6 8}$ \\
Grand Values & $-23 ; 16$ & $\mathbf{- 3}$ & $24 ; 41$ & $\mathbf{3 3}$ & $5 ; 168$ & $\mathbf{7 9}$ \\
\hline
\end{tabular}

Group-III species are eastern species and are suggested to be limited in their westward expansion by moisture availability (Miller, 1976): Carychium exiguum, Gastrocopta armifera, Gastrocopta contracta, Gastrocopta tappaniana, Helicodiscus parallelus, Laevapex fuscus and Planorbula armigera. The biogeographic ranges of the species on this list appear to fit their designation as eastern species. These species tend to terminate their ranges on the Great Plains with only scattered occurrences farther west and no occurrences in Alaska or Hawaii. All the species on this list are found throughout the Midwest, Northeast, Southwest and Southeast States, with extremely few occurrences in the Mountain States and no occurrences in the Contiguous Pacific States. Within the areas they do occur however, species distributions differ. Some like G. contracta, H. parallelus, G. armifera and G. tappaniana, are common and broadly distributed throughout their biogeographic range. Carychium exiguum, L. fuscus and $P$. armigera tend to be rarer and are generally restricted to areas north of the Missouri and Ohio Rivers.

The climate tolerances for Group-IIl species can be found in Table 11. Again, it can be seen that the component species are broadly similar in their climate requirements. Comparison of Grand Values and Means to the other two similar Tables shows very similar temperatures to Groups-I and II. However, Group-III appears to suggest a much wetter climate. 
Table 11. Group-III Climate. Summary of the environmental tolerances for Group-III species of Miller $(1975,1976)$ and this study. Species names are abbreviated see Appendix 3 for the full names. MinTmean minimum temperature for January, MaxT - mean maximum temperature for July, PRECIP-mean annual precipitation, $\mathrm{R}-$ range displayed using the format "smallest value; largest value", $\mathbf{M}-$ mean value. Grand Values are the estimated climate for this group.

\begin{tabular}{c|cc|cc|cc}
\hline \multirow{2}{*}{ TAXA } & \multicolumn{2}{|c|}{$\operatorname{MinT}\left({ }^{\circ} \mathrm{C}\right)$} & \multicolumn{2}{|c|}{$\operatorname{MaxT}\left({ }^{\circ} \mathrm{C}\right)$} & \multicolumn{2}{|c}{ PRECIP $(\mathrm{cm})$} \\
& $\mathrm{R}$ & $\mathrm{M}$ & $\mathrm{R}$ & $\mathbf{M}$ & $\mathrm{R}$ & $\mathbf{M}$ \\
\hline C. exiguum & $-24 ; 16$ & $\mathbf{- 7}$ & $21 ; 37$ & $\mathbf{3 0}$ & $25 ; 157$ & $\mathbf{9 3}$ \\
G. armifera & $-23 ; 7$ & $\mathbf{- 5}$ & $26 ; 37$ & $\mathbf{3 2}$ & $25 ; 168$ & $\mathbf{9 6}$ \\
G. contracta & $-24 ; 16$ & $\mathbf{- 4}$ & $24 ; 38$ & $\mathbf{3 2}$ & $25 ; 168$ & $\mathbf{1 0 2}$ \\
G. tappaniana & $\mathbf{- 2 4 ; 1 4}$ & $\mathbf{- 4}$ & $21 ; 37$ & $\mathbf{3 2}$ & $25 ; 168$ & $\mathbf{9 9}$ \\
H. parallelus & $-24 ; 13$ & $\mathbf{- 4}$ & $21 ; 38$ & $\mathbf{3 1}$ & $15 ; 168$ & $\mathbf{1 0 4}$ \\
L. fuscus & $-22 ; 6$ & $\mathbf{- 6}$ & $26 ; 34$ & $\mathbf{3 0}$ & $61 ; 168$ & $\mathbf{1 0 1}$ \\
P. armigera & $-24 ; 11$ & $\mathbf{- 1 0}$ & $25 ; 36$ & $\mathbf{2 9}$ & $43 ; 127$ & $\mathbf{8 8}$ \\
Grand Values & $-24 ; 16$ & $\mathbf{- 6}$ & $21 ; 38$ & $\mathbf{3 1}$ & $\mathbf{1 0} ; 168$ & $\mathbf{9 8}$ \\
\hline
\end{tabular}

According to Miller $(1975,1976)$, Group-IV species are not useful for climate determination for a variety of reasons, including poorly-known biogeographic ranges, extremely broad biogeographic ranges, or are known not to be limited by climatic factors, or are extinct. Species in this study which are in common with Miller's (1976) Group-IV are: Deroceras laeve, Euconulus fulvus, Ferrissia fragilis, Fossaria dalli, Fossaria obrussa, Gyraulus parvus, Hawaiia mimuscula, Planorbella trivolvis, Pupoides albilabris, Vallonia parvula, Vertigo milium, Vertigo ovata and Zonitoides arboreus. Extinct species Promenetus kansasensis and Gastrocopta scaevoscala do not have biogeographic range maps in this study. As mentioned in the Methods section, the extinct Deroceras aenigma and the extant $D$. laeve are considered synonymous in this study. In Miller's $(1975,1976)$ studies, species of the Physidae, Succineidae and Pisidiidae were distributed among the climate groups. In this study, all such species were analyzed together at the family rank for reasons given in the Methods section. As such, the Physidae, Succineidae and Pisidiidae are recognized herein as Group-IV taxa. In keeping with Miller's $(1975,1976)$ assessment, the species in this list are very broadly distributed throughout the United States with some having occurrences in Alaska and/or Hawaii. The record holder is Z. arboreus which, in this study, occurs in every state except Alaska and is known to occur in 1527 counties, far more counties than any other taxon examined in this study. Table 12 shows the climate tolerances for Group-IV species. The Grand Values for this group are comparable to the Grand Values for the previous three Groups. 
Table 12. Group-IV Climate. Summary of the environmental tolerances for Group-IV species of Miller $(1975,1976)$ and this study. Species names are abbreviated see Appendix 3 for the full names. MinTmean minimum temperature for January, MaxT — mean maximum temperature for July, PRECIP_-mean annual precipitation, $\mathrm{R}$-range displayed using the format "smallest value;largest value", $\mathbf{M}-$ mean value. Grand Values are the estimated climate for this group.

\begin{tabular}{c|cc|cc|cc}
\hline \multirow{2}{*}{ TAXA } & \multicolumn{2}{|c|}{$\operatorname{MinT}\left({ }^{\circ} \mathrm{C}\right)$} & \multicolumn{2}{|c|}{$\operatorname{MaxT}\left({ }^{\circ} \mathrm{C}\right)$} & \multicolumn{2}{|c}{ PRECIP $(\mathbf{c m})$} \\
& $\mathrm{R}$ & $\mathbf{M}$ & $\mathrm{R}$ & $\mathbf{M}$ & $\mathrm{R}$ & $\mathbf{M}$ \\
\hline D. laeve & $-31 ; 23$ & $\mathbf{- 5}$ & $\mathbf{8} ; 39$ & $\mathbf{3 0}$ & $5 ; 348$ & $\mathbf{9 5}$ \\
E. fulvus & $-24 ; 4$ & $\mathbf{- 8}$ & $12 ; 39$ & $\mathbf{3 0}$ & $5 ; 274$ & $\mathbf{8 3}$ \\
F. fragilis & $-16 ; 4$ & $\mathbf{- 5}$ & $21 ; 34$ & $\mathbf{3 1}$ & $43 ; 274$ & $\mathbf{1 0 9}$ \\
F. dalli & $-23 ;-1$ & $\mathbf{- 8}$ & $26 ; 36$ & $\mathbf{3 3}$ & $15 ; 107$ & $\mathbf{7 3}$ \\
F. obrussa & $-24 ; 8$ & $\mathbf{- 1 0}$ & $19 ; 37$ & $\mathbf{3 0}$ & $\mathbf{1 0} ; 142$ & $\mathbf{7 3}$ \\
G. parvus & $\mathbf{- 3 1 ; 1 6}$ & $\mathbf{- 1 0}$ & $\mathbf{8} ; 39$ & $\mathbf{3 0}$ & $5 ; 183$ & $\mathbf{7 4}$ \\
H. minuscula & $-24 ; 23$ & $\mathbf{- 3}$ & $19 ; 41$ & $\mathbf{3 2}$ & $5 ; 348$ & $\mathbf{1 0 0}$ \\
P. trivolvis & $\mathbf{- 3 3} ; 16$ & $\mathbf{- 8}$ & $21 ; 39$ & $\mathbf{3 1}$ & $5 ; 157$ & $\mathbf{8 3}$ \\
P. albilabris & $-16 ; 12$ & $\mathbf{- 3}$ & $24 ; 42$ & $\mathbf{3 2}$ & $5 ; 168$ & $\mathbf{9 9}$ \\
V. parvula & $-22 ; 4$ & $\mathbf{- 7}$ & $26 ; 37$ & $\mathbf{3 3}$ & $28 ; 127$ & $\mathbf{7 5}$ \\
V. milium & $-23 ; 16$ & $\mathbf{- 3}$ & $23 ; 37$ & $\mathbf{3 2}$ & $28 ; 165$ & $\mathbf{1 0 5}$ \\
V. ovata & $\mathbf{- 2 4 ; 1 6}$ & $\mathbf{- 5}$ & $18 ; 39$ & $\mathbf{3 1}$ & $5 ; 178$ & $\mathbf{9 7}$ \\
Z. arboreus & $-24 ; 23$ & $\mathbf{- 4}$ & $19 ; 41$ & $\mathbf{3 1}$ & $5 ; 348$ & $\mathbf{1 0 0}$ \\
Grand Values & $-33 ; 23$ & $\mathbf{- 6}$ & $\mathbf{8} ; 42$ & $\mathbf{3 1}$ & $5 ; 348$ & $\mathbf{9 0}$ \\
\hline
\end{tabular}

The results of the one way ANOVA for minimum temperature suggested a significant difference $(p<0.0001)$ exists among the four Climate Groups. The Tukey-Kramer HSD test found differences in minimum temperature between Groups-II/I, III/I and IV/I (Figure 6). 


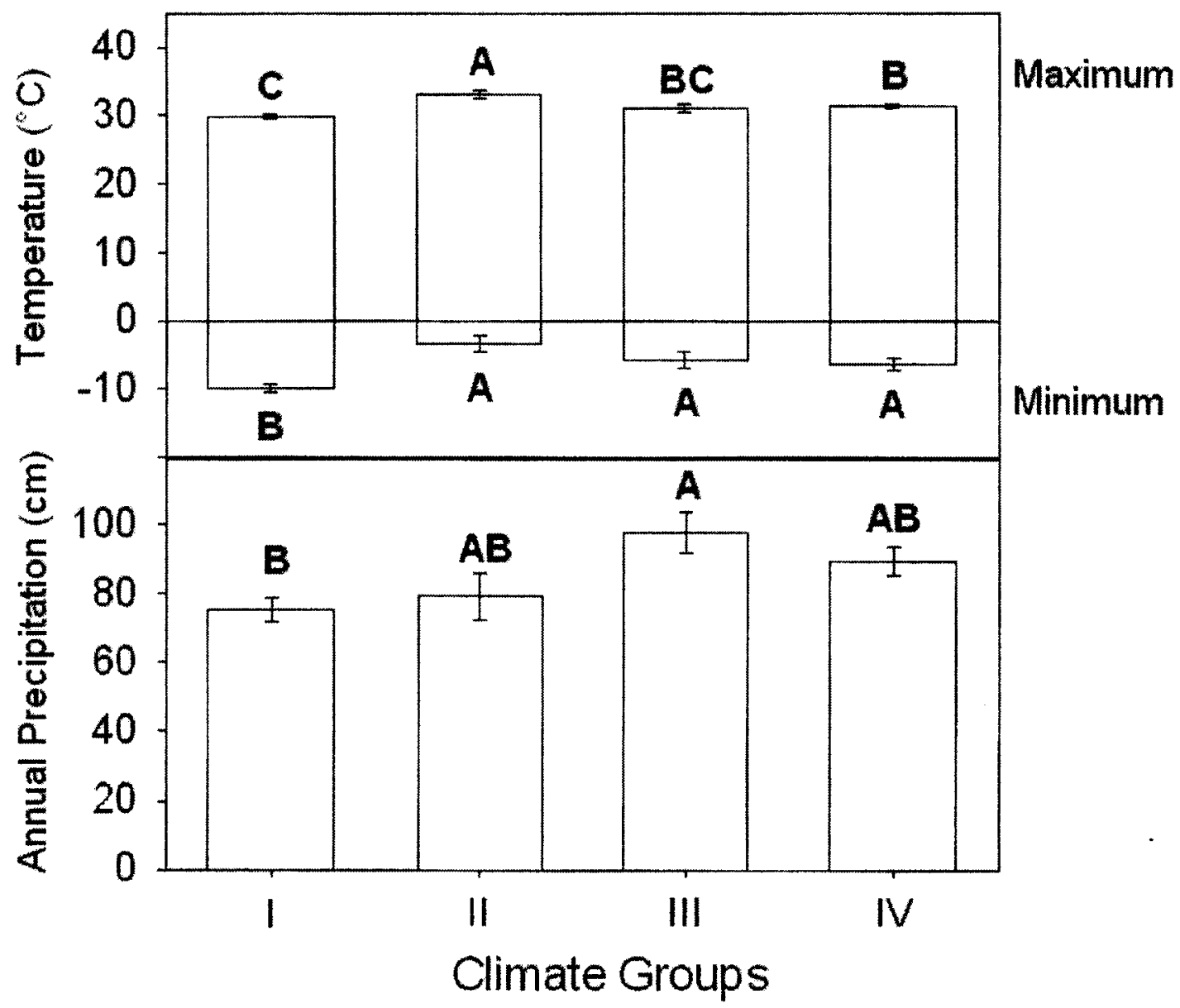

Figure 6. ANOVA Results for Climate Groups. Graph depicting the results of a one way ANOVA and a Tukey-Kramer HSD test for differences in minimum temperature, maximum temperature and annual precipitation among the four Climate Groups. Bars bearing different letters are significantly different from one another. Error bars show standard error.

These ANOVA results are surprising, given the apparent environmental similarity among various taxa. The most important comparisons are with Climate Group-IV. Miller $(1975,1976)$ determined that Group-IV taxa were unsuitable for climate reconstructions; therefore Group-IV serves as a control. Despite the significant ANOVA, only those Groups that are significantly different from Group-IV suggest a real climate signal. For minimum temperature, only Climate Group-I displays a significant difference from Group-IV. Other Groups cannot be distinguished from Group-IV, thus they don't provide meaningful climate information. The null hypothesis that there is no relationship between minimum temperature and species composition $\left(\mathrm{H}_{\mathrm{O} 2}\right)$ is rejected, but there is not a strong minimum temperature signal.

For maximum temperature, a one way ANOVA was also significant $(p<0.0001)$. The subsequent 
Tukey-Kramer HSD test found differences in maximum temperature between Groups-II/I, II/III, II/IV and IV/I (Figure 6). Only Climate Groups-I and II were significantly different from Group-IV, suggesting a real climate signal. The results support a weak relationship between maximum temperature and species composition.

The one way ANOVA did find a significant difference $(p=0.0082)$ in precipitation among the four Climate Groups. A Tukey-Kramer HSD test found differences in precipitation between Groups-III/I. All other pairings displayed no differences in precipitation (Figure 6). Since none of the Climate Groups (I, II or III) display a significant difference between themselves and Group-IV, there is no climate signal for precipitation-the difference between Groups-I and III, while mathematically significant is not ecologically meaningful.

The new biogeographic range maps produced for this study show that many species previously indentified by Miller (1976) as northern or southern are in fact much more broadly distributed, suggesting placement in Miller's (1976) Climate Group-IV. This regrouping of species, in light of subsequent knowledge of their current distributions, would undermine the concept of Climate Groups. There are additional species examined in this study which were not part of Miller's $(1975,1976)$ Climate Groups. Biogeographic range maps were also produced for these species, and their climate tolerances can be found in Appendix 7. Climatic interpretations in this study were based on the biogeographic ranges of all the species examined in this study.

Table 13 displays the Grand Means and Grand Ranges for each fossil assemblage examined in this study. (Data for the individual species within each assemblage used to compile the Grand Values are not shown but can be found in Appendix 7; data for the three families were not used in the compilation of Grand Ranges or calculation of Grand Means, because the broad biogeographic ranges at that taxonomic level would bias the climate towards more eurythermic/euryhydric conditions.) For each fossil assemblage, the lowest minimum value and highest maximum value for each climate variable is listed as the Grand Range for the assemblage. All of the means for the included taxa were used to calculate the Grand Mean for the assemblage. These Grand Values constitute the estimated climate that existed in southwest Kansas for each assemblage when the fossils were alive. For comparison, a Random assemblage has been added, composed of 15 randomly selected molluscan taxa (see the Statistical Procedures and Mapping section for 
the list of included species).

Table 13. Fossil Assemblage Climate. Grand Values for the fossil molluscan assemblages used in this study. MinT - mean minimum temperature for January, MaxT - mean maximum temperature for July, PRECIP-mean annual precipitation, R-range displayed using the format "smallest value;largest value", M-mean value. The Random assemblage is composed of 15 species selected randomly from Appendix 7.

\begin{tabular}{|c|c|c|c|c|c|c|}
\hline \multirow{2}{*}{ ASSEMBLAGES } & \multicolumn{2}{|c|}{$\operatorname{MinT}\left({ }^{\circ} \mathrm{C}\right)$} & \multicolumn{2}{|c|}{$\operatorname{Max} T\left({ }^{\circ} \mathrm{C}\right)$} & \multicolumn{2}{|c|}{ PRECIP $(\mathrm{cm})$} \\
\hline & $\mathrm{R}$ & $\mathbf{M}$ & $\mathrm{R}$ & M & $\mathrm{R}$ & $\mathbf{M}$ \\
\hline Random & $-31 ; 23$ & -7 & $8 ; 41$ & 31 & $5 ; 348$ & 84 \\
\hline RNT & $-33 ; 23$ & -6 & $8 ; 42$ & 32 & $5 ; 348$ & 83 \\
\hline RTB & $-33 ; 23$ & -6 & $8 ; 41$ & 31 & $5 ; 348$ & 88 \\
\hline RTA & $-33 ; 23$ & -6 & $8 ; 41$ & 31 & $5 ; 348$ & 86 \\
\hline BDL & $-31 ; 23$ & -7 & $8 ; 39$ & 31 & $5 ; 348$ & 83 \\
\hline CL2 & $-24 ; 23$ & -2 & $8 ; 42$ & 32 & $5 ; 348$ & 89 \\
\hline CL1 & $-31 ; 23$ & -8 & $8 ; 39$ & 30 & $5 ; 348$ & 83 \\
\hline BD2 & $-31 ; 16$ & -8 & $8 ; 39$ & 31 & $5 ; 183$ & 76 \\
\hline JQB & $-31 ; 23$ & -6 & $8 ; 42$ & 31 & $5 ; 348$ & 87 \\
\hline$J Q A$ & $-31 ; 23$ & -7 & $8 ; 42$ & 31 & $5 ; 348$ & 86 \\
\hline M35 & $-31 ; 23$ & -7 & $8 ; 41$ & 31 & $5 ; 348$ & 79 \\
\hline SPB & $-31 ; 23$ & -8 & $8 ; 39$ & 31 & $5 ; 348$ & 77 \\
\hline SPA & $-31 ; 23$ & -5 & $8 ; 39$ & 31 & $5 ; 348$ & 82 \\
\hline CR7 & $-31 ; 23$ & -6 & $8 ; 42$ & 31 & $5 ; 348$ & 89 \\
\hline CO3B & $-33 ; 23$ & -7 & $8 ; 41$ & 31 & $5 ; 348$ & 87 \\
\hline $\mathrm{CO} 3 \mathrm{~A}$ & $-31 ; 23$ & -7 & $8 ; 39$ & 31 & $5 ; 348$ & 84 \\
\hline $\mathrm{CH} 4$ & $-31 ; 23$ & -7 & $8 ; 41$ & 31 & $5 ; 348$ & 82 \\
\hline $\mathrm{CHY}$ & $-31 ; 23$ & -7 & $8 ; 41$ & 31 & $5 ; 348$ & 89 \\
\hline PMA & $-31 ; 23$ & -4 & $8 ; 41$ & 31 & $5 ; 348$ & 90 \\
\hline B1B & $-31 ; 23$ & -4 & $8 ; 41$ & 32 & $5 ; 348$ & 93 \\
\hline $\mathrm{X} 1 \mathrm{E}$ & $-31 ; 23$ & -4 & $8 ; 41$ & 32 & $5 ; 348$ & 95 \\
\hline $\mathrm{X} 2 \mathrm{~B}$ & $-31 ; 23$ & -4 & $8 ; 42$ & 32 & $5 ; 348$ & 83 \\
\hline R1A & $-24 ; 23$ & -5 & $8 ; 41$ & 32 & $5 ; 348$ & 74 \\
\hline RYA & $-24 ; 23$ & -5 & $19 ; 41$ & 32 & $5 ; 348$ & 88 \\
\hline RFX & $-24 ; 23$ & -5 & $19 ; 41$ & 32 & $5 ; 348$ & 75 \\
\hline TFC & $-31 ; 23$ & -7 & $8 ; 41$ & 31 & $5 ; 348$ & 87 \\
\hline FAL & $-31 ; 16$ & -7 & $8 ; 39$ & 31 & $5 ; 183$ & 70 \\
\hline AGO & $-31 ; 23$ & -2 & $8 ; 41$ & 33 & $5 ; 348$ & 90 \\
\hline
\end{tabular}

The data in Table 13 shows that the climate suggested by each fossil assemblage varies very little through the study period. When examined sequentially, there is almost no change in temperature from one fossil assemblage to the next but precipitation can change. A one way ANOVA (via JMP) was applied to the 28 assemblages summarized in Table 13 to test the hypothesis that there is no difference among the assemblages for the various climate variables. No significant differences were found among the 28 assemblages for minimum temperature $(p=0.0714)$ or precipitation $(p=0.691)$. However, the ANOVA did find a significant difference for maximum temperature $(p=0.0207)$ but the subsequent Tukey-Kramer 
HSD test failed to find any differences among the assemblages. The climate data from fossil molluscan assemblages indicates that either a nearly static climate has existed through the five million years of this study (which is known not to be true, see the oxygen isotope graph in Appendix 8) or that molluscan taxa are not limited by climate. The data in Table 13 supports $\mathrm{H}_{\mathrm{O} 2}$.

\section{Multivariate Statistics}

The results of the application of NMS to the data contained in the CD and MBD are presented in

Figure 7.

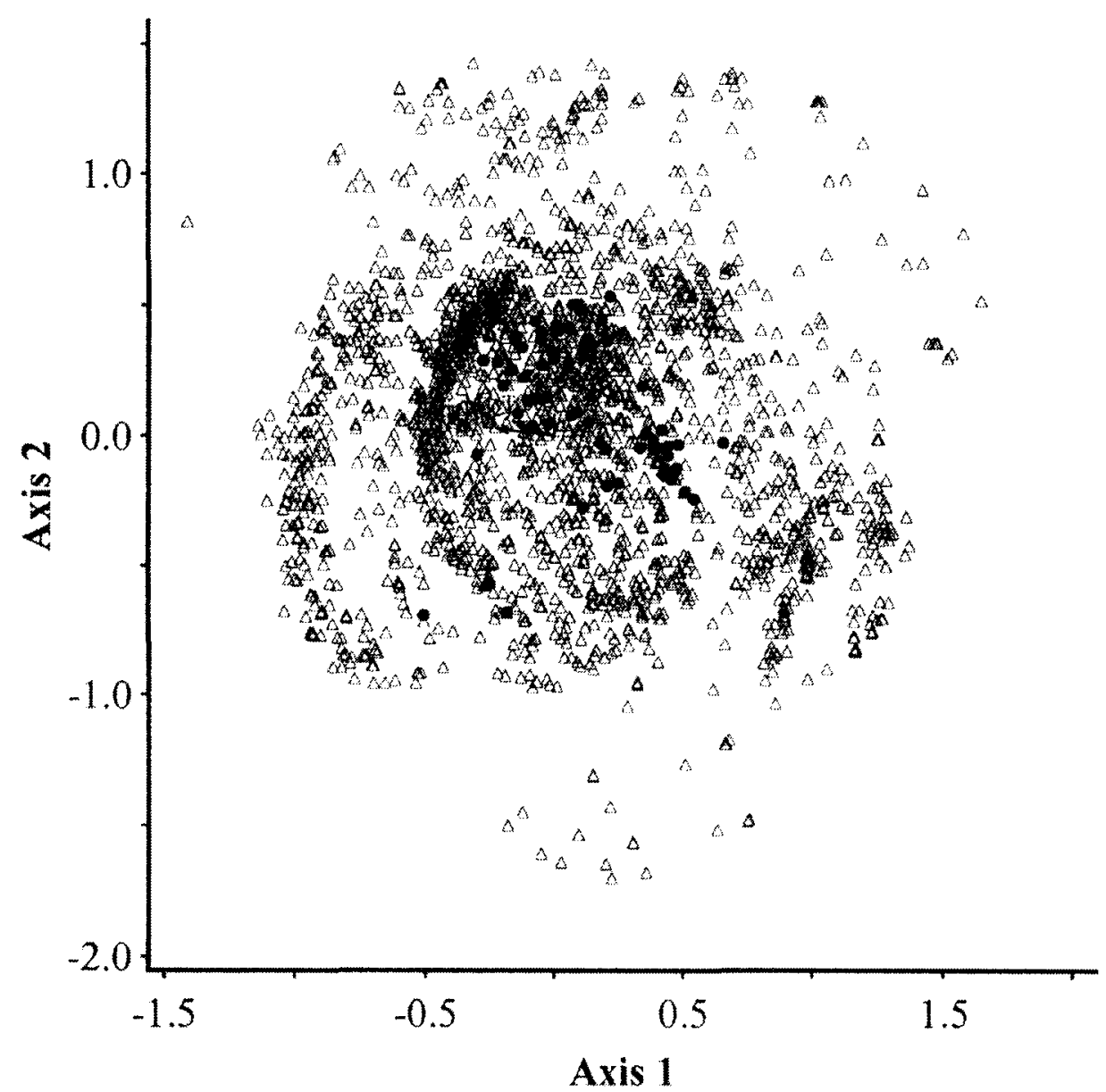

Figure 7. Ordination Results for Counties. Plot of counties of the United States and the extant molluscan taxa examined in this study. Triangles-counties, dots-molluscan taxa. 
In this figure, triangles represent the counties of the United States. Only those counties which contained at least one molluscan taxon are included, thus 2486 counties are displayed on the graph of ordination space. Sixty-two extant species are plotted on the same graph with dots. Ordination space is here represented by Axes 1 and $2\left(r^{2}\right.$ for Axis $1=0.230, r^{2}$ for Axis $\left.2=0.198\right)$.

The counties are plotted based on similarities of taxonomic composition, moderated by similarities of minimum temperature, maximum temperature and annual precipitation. Counties with similar values plot close together while counties with different values plot farther apart. The molluscan taxa are plotted by the same climate variables. Vegetation and elevation were not used in this analysis for the following reasons: 1) the vegetation variable contained too many categories for PC-ORD to handle and 2) elevation was removed because it was logically correlated with temperature and possibly precipitation, likely yielding spurious results.

The pattern displayed by the counties in Figure 7 is globular, suggestive of low significance. Climate vectors, when overlaid on the graph, barely radiate away from the origin $(r=0.010,100 \%)$ : the precipitation vector is nearly parallel to Axis 1 and points in the negative Axis 1 direction, the minimum temperature vector trends negatively on Axis 1 and positively on Axis 2 and the maximum temperature vector is nearly parallel to Axis 2 and trends positively. The regression line for minimum temperature decreases in the positive Axis 1 direction $(r=-0.303)$ and increases in the positive Axis 2 direction $(r=$ 0.177), the regression line for maximum temperature decreases in the positive Axis 1 direction $(r=-0.014)$ and increases in the positive Axis 2 direction $(r=0.211)$ and the regression line for precipitation decreases in the positive Axis 1 direction $(r=-0.356)$ and increases in the positive Axis 2 direction (0.126). Due to the low significance of the ordination data, there are no groupings in ordination space which can be explained by similarity in taxonomic composition, temperature or precipitation, therefore supporting $\mathrm{H}_{\mathrm{O} 2}$.

Figure 8 was constructed to display the position of the molluscan taxa in ordination space without the obscuring counties. Statistical and climatic implications are the same as in Figure 7. 


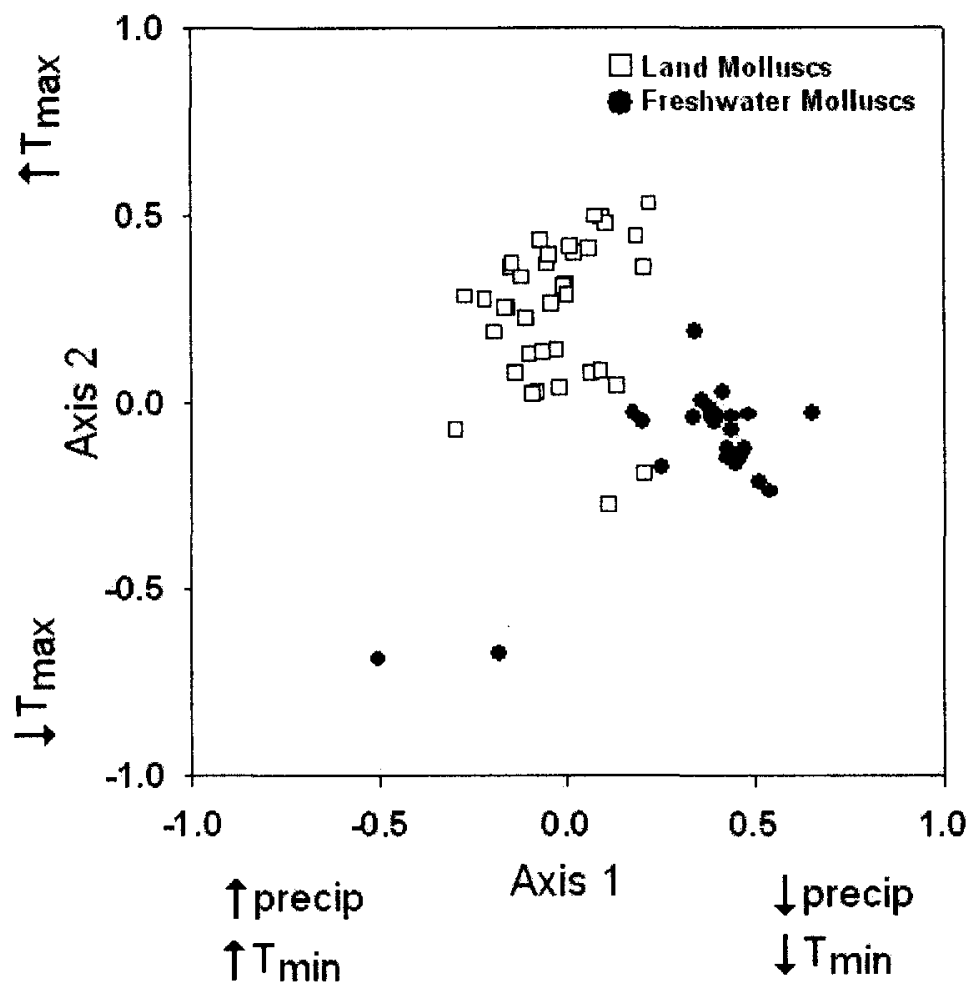

Figure 8. Ordination Space for Molluscs. Graph of the same ordination space seen in Figure 7 but with counties removed for clarity. Square--land molluscs, dots-freshwater molluscs. Minimum temperature increases in the negative Axis 1 direction, maximum temperature increases in the positive Axis 2 direction and precipitation increases in the negative Axis 1 direction.

Although the graph does not display significant trends in climate for the ordination space,

freshwater and land taxa group separately: most land taxa plot negatively along Axis 1 and positively along Axis 2, while most freshwater taxa plot positively along Axis 1 and negatively along Axis 2 . The separation of taxa into freshwater and land groups is unexpected as PC-ORD was not told which taxa were freshwater and which were land taxa. The land taxa plot slightly warmer and wetter in ordination space while the freshwater taxa plot slightly cooler and drier in ordination space. This result is unexpected and perplexing as many of these taxa co-occur in the same counties at the same time. 


\section{DISCUSSION}

The initial purpose of this study was to use fossil molluscan assemblages from the Meade Basin of southwest Kansas to provide an estimate of past climate conditions. As the study progressed, it became apparent that it was necessary to provide a test of the general proposition that there were significant climate signals among the extant taxa that could be applied to fossil molluscan assemblages. The results were mixed. Alpha and beta diversity statistics did reveal that molluscan assemblages of southwest Kansas changed in taxonomic composition and relative abundances through time, but the changes appeared to be randomly directed. Statistical support for climate differences among Miller's $(1975,1976)$ Climate Groups was found, which suggests that the technique might be useful in paleoecology, but the fossil assemblages collected for this study provided little indication of climate flux. Collectively, the results did not provide strong support for using molluscs as environmental indicators for interpreting paleoclimate. Instead, what was found is that mollusc species are very broadly distributed within the United States: a species can be found living under a variety of different temperature and precipitation regimes, different vegetation types and at multiple elevations. In short, molluscan species tend to be eurythermic and/or euryhydric, and thus are not suitable for climate reconstructions.

The use of molluscs as climate indicators appears to rest on some misconceptions of molluscan biology, such as: 1) molluscan biogeography is sufficiently known, therefore the climate they live under is sufficiently known; 2) molluscs have very limited powers of dispersal; and 3) molluscan physiology is

tuned to narrow tolerances for temperature and moisture. Assumptions about molluscan biogeography are important because, from a paleontologist's perspective, it is the starting point for any attempt at climate reconstruction using animals as climate indicators-where the taxon of interest occurs or does not occur has implications for the climate that taxon can tolerate. It is therefore essential to have accurate biogeographic range records for molluscan species, if they are to be used to estimate paleoclimate. Unfortunately, such detailed national maps were not available until recently and highly idealized national 
range maps have been used instead.

For many decades there has been detailed biogeographic information at the county level or lower for individual states. However this information was distributed among many different papers published over many years (see Appendix 2), which made it very difficult to view the details of molluscan biogeography from a national perspective. It appears that the first attempt to make national maps of molluscan biogeography with county level resolution was not until 1985, with the production of Hubricht's (1985) maps of the eastern United States. However, Hubricht's (1985) maps were not truly national as almost all of his maps end with the states of the Great Plains. Even before 1985, it was known that some molluscan species found in the eastern part of the country also occur west of the Continental Divide, including (for some species) Alaska and Hawaii. Moreover, Hubricht (1985) only mapped land species, not freshwater species. As yet, there are no known national biogeographic range maps for freshwater species using county level resolution. The second attempt to make a national map of molluscan biogeography at the county level of resolution was done in 2010 by Nekola and Coles (2010), but they also did not include all 50 states, and they only mapped the land gastropod family Pupillidae. Molluscan biogeography is not static: intentionally or not, humans have been important vectors aiding in the spread of molluscan species beyond their "natural" ranges. This human-aided dispersal has made old biogeographic range maps obsolete; if any large section of a biogeographic range is missing, erroneous assessments of climate tolerances for that species could result. This must be taken into consideration when using biogeographic ranges to infer climate tolerances.

Additionally, in the paleontological literature, there is the implied assumption that there is a "typical" area for a given molluscan species to exist, and other occurrences elsewhere can be considered as unusual or anomalous (and therefore unimportant). In this way, an entire species can be labeled as exclusively "warm weather," "boreal," or some other climate-based label, even though stable populations of the species were known to be present in other habitats. An example of this approach comes from Frye and Leonard (1967) concerning Zonitoides arboreus, which according to them, has "... fairly well-known and limited ecological requirements and thus are of considerable use in interpreting past ecologies. For example, such species as ... Zonitoides arboreus, ... are known to live in forests or in forest-border situations and rarely, or never, in prairie habitats; ... The compete absence of these and related species in 
the Great Plains, ... leads to the conclusion that the Great Plains region in general was not forested in late Cenozoic time (Frye and Leonard, 1967, p. 433)." Thus, according to the authors, Z. arboreus is indicative of forested areas, the locations in unforested habitats being unimportant and not useful for paleoecology.

A look at the biogeographic range map in this study for $Z$. arboreus shows that this species is virtually continental in distribution and lives in a variety of vegetation types (Appendix 7). True, it is rare on the Great Plains, but it does occur there. This broad distribution is certainly not expected of a species with "limited ecological requirements" as suggested by Frye and Leonard (1967). Because $Z$. arboreus can be found under virtually all climate conditions in the United States and can live at different elevations and in nearly all the vegetation types as well, it is not a good candidate for reconstructing paleoclimate, as Miller $(1975,1976)$ understood. (It should be noted that $Z$. arboreus was not recorded from Alaska in this study. However, the species was reported from Alaska [Baxter, 1987], but publications which provided that location data in a form suitable for use in the MBD could not be found.) In this study it was assumed that there are no typical areas for a given molluscan species; every known occurrence was given equal importance because wherever a mollusc can make a living, the climate of that area is tolerable to it and is part of the climate tolerance for the species as a whole.

In general, dispersal can be assigned to two different categories: 1) slow gradual diffusion, where the population gradually moves across the landscape over time, and 2) jump dispersal, where the population spreads much more rapidly, possibly crossing inhospitable terrain (Pielou 1979). If molluscan species are not limited in their distribution by slow diffusion dispersal, (the second assumption), then how is it that freshwater and land molluscs can travel the great distances necessary to produce the observed alpha and beta biodiversity patterns in this study? There are several possibilities, including active dispersal through transgenerational migration and passive transportation via several vectors: 1) floods (which are the cause of the drift shells, mentioned in the biogeographic literature);2) other animals; and 3) violent storms. Transportation via human action, prevalent in the modern world, is not a concern in paleoecology.

Passive transportation of molluscs via animal vectors, both vertebrate (birds, fish and others) and invertebrate (flying insects) are known from both experimental and anecdotal evidence (Darwin, 1882; Malone, 1965; Rees, 1965; Boag, 1986; Brown, 2007). Malacologists have long assumed that the ability of molluscs to be transported long distances by storms (thunderstorms, tornados and hurricanes) is possible, 
although positive data for this is hard to find and must generally be inferred. (It is not difficult to imagine that the leaf litter in which gastropods reside can be blown great distances.) Rees (1965) mentions one confirmed instance of molluscs transported by storms in Germany: in 1892, hundreds of individuals of the bivalve Anodonta anatina were picked up from some source during a thunderstorm and dropped on the city of Paderborn.

Active dispersal of gastropods across great distances requires more explanation because of the counterintuitive nature of the claim. Baur and Baur (1992) examined the dispersal abilities of the Swiss land snail Arianta arbustorum. With an adult shell diameter from $16 \mathrm{~mm}$ to $20 \mathrm{~mm}$, A. arbustorum is a medium-sized snail using Burch's (1982) definition (10mm to $30 \mathrm{~mm}$ ). The median daily dispersal distance for $A$. arbustorum was found to be $0.58 \mathrm{~m}$. Using this value, the plausibility of dispersal via migration can be examined by asking: how far could $A$. arbustorum travel (by transgenerational migration) in one million years? Performing the following mathematical operation, we get:

$$
(0.58 \mathrm{~m} / \text { day) }(365 \text { days } / \text { year })(1,000,000 \text { years })=211,700,000 \mathrm{~m}=211,700 \mathrm{~km}
$$

Thus, $A$. arbustorum could travel $211,700 \mathrm{~km}$ in one million years, a distance which greatly exceeds the straight-line distance between Barrow, Alaska, and Miami, Florida $(6,829 \mathrm{~km}$, estimated using USGS [2006]). In generating this value it was assumed that the snail moved in the same direction, at the same rate, for its entire life. Offspring produced by this snail continued the trek in the same direction at the same rate for their lifetimes as well, and so on, for many generations. With movement of this magnitude possible and sufficient time available, it is plausible that snails could cross long distances completely unaided.

This assessment of transgenerational migration is somewhat unrealistic for several reasons: 1) as indicated by Baur and Baur (1995), different species could be expected to travel different distances per time; 2) Baur and Baur (1992) state that the day-to-day movements of $A$. arbustorum display no preference for direction, except that they refuse to leave their preferred vegetation; and 3) the willingness of snails to move often depends on a variety of abiotic attributes, including substrate type, temperature and available moisture. The Baur and Baur (1992) study reflects dispersal on a daily temporal scale. However on the order of millions of years, the temporal scale at which climate and vegetation patterns are fluid, Equation 4 
becomes a plausible model of land gastropod dispersal abilities in general.

All of the transportation/dispersal scenarios discussed above demonstrate that freshwater and land molluscs can and do cross geographic distances in various ways, but the same studies suggest that these methods are unpredictable in frequency of occurrence and variable in distance traveled. However, over millennia, rare events can become certainties and small-scale geographic movements can sum over generations to involve large-scale distances. The particular species involved in these rare transportation events are likely randomly chosen and do not reflect any special aspects of the species' physiology or behavior. The major barriers to dispersal, then, are problems related to establishment in the new area-the local climate and vegetation must be tolerable to the invading molluscs.

The final assumption that molluscs have narrow climate tolerances and therefore that molluscan composition of an area reflects the local climate is contradicted by molluscs' ability to acclimate to changing environmental conditions. Several studies have investigated the temperature tolerances freshwater gastropods have by noting the temperature at which gastropods cease to behave naturally. This point is defined in different but comparable ways, including the heat coma tolerance, the temperature at which a snail detaches from the substrate, curls its foot and becomes immobile; the critical thermal maxima, the temperature at which a snail retreats into its shell; escape behavior, a condition where a snail retreats into its shell at an elevated temperature; lack of self-righting, a behavioral response to low temperatures where a snail becomes immobile and is unable to right itself if pushed over. The different conditions for the limits of tolerances are needed because not all snail species react the same way to temperature extremes. As an example, McMahon and Payne (1980) found that the upper limit of thermal tolerances of Texas populations of the snail Physa virgata, acclimated to $20^{\circ} \mathrm{C}$, could change from $35.2^{\circ} \mathrm{C}$ to $39.3^{\circ} \mathrm{C}$ over a six day period, before stabilizing at $38.23^{\circ} \mathrm{C}$ after six days. Different populations of $P$. virgata were found to differ in their maximum thermal tolerances and ranged from $35.61^{\circ} \mathrm{C}$ to $40.13^{\circ} \mathrm{C}$. Ross and Ultsch (1980) examined two species of Goniobasis from Alabama for maximum temperature tolerances. At the highest acclimation temp $\left(23^{\circ} \mathrm{C}\right.$ to $\left.24^{\circ} \mathrm{C}\right)$, G. cahawbensis reached its thermal maximum at $36.7^{\circ} \mathrm{C}$, for upstream populations and $35.9^{\circ} \mathrm{C}$ for downstream populations. For G. carinifera, the maximum temperature was $36.2^{\circ} \mathrm{C}$. Lysne and Koetsier (2006) investigated Valvata utahensis and Pyrgulopsis idahoensis from Idaho for both maximum and minimum temperature tolerances. It was 
determined that $V$. utahensis ceased activity at temperatures greater than $31.7^{\circ} \mathrm{C}$ and lower than $7.3^{\circ} \mathrm{C}$ while $P$. idahoensis ceased activity at temperatures greater than $33.7^{\circ} \mathrm{C}$ and below $9.2^{\circ} \mathrm{C}$. The minimum temperature at which activity ceases is comparable to the temperatures that the reservoirs (from which the snails were collected) attain in October and November, while the maximum temperature where actively ceases exceeds the temperature that these reservoirs reach.

Riddle (1990) studied the survival of three land snails from Illinois under different temperature conditions. Field-caught (unacclimated) animals displayed $\mathrm{L}_{\text {temp }} 50$ values (the temperature which is lethal to $50 \%$ of the investigated snails) of $38.6^{\circ} \mathrm{C}$ for Oxyloma retusa, $44.1^{\circ} \mathrm{C}$ for Gastrocopta armifera and $37.9^{\circ} \mathrm{C}$ for Discus cronkhitei (= Discus whitneyi herein). Acclimation to $15^{\circ} \mathrm{C}$ or $30^{\circ} \mathrm{C}$ had an effect on the survivability for these species relative to the unaclimated condition, with often lower survival at low temperature acclimation and higher survival at higher temperature acclimation. Although not explicitly studied by Riddle (1990), the temperature at which 100\% mortality is reached (and thus the thermal limit of the species studied) can be estimated from the author's Figures 1, 2 and 3. Oxyloma retusa appears to reach $100 \%$ mortality at approximately $40^{\circ} \mathrm{C}$, G. armifera will reach $100 \%$ mortality at a temperature greater than $45^{\circ} \mathrm{C}$ (the actual value cannot be estimated from the author's Figure 2) and $D$. cronkhitei reaches $100 \%$ mortality at about $39^{\circ} \mathrm{C}$.

The above results show that some snails can tolerate a wide variety of temperatures, even outside the range of temperatures typically seen in the environments from which they were collected. It is this ability to tolerate wide temperature ranges that enable snails to live in a variety of places having different local climates and accounts for their ability to become naturalized in locations outside of their natural ranges. The high level of tolerance exhibited by molluscs, along with the lack of a clear statistical endorsement of the use of molluscs as environmental indicators from the present study, suggests that current molluscan biogeographic distributions has limited value for paleoecologic reconstructions. Molluscan taxa may move into and out of the study area through time, but these movements are likely in response to something other than climate, possibly including pressure from competitors, predators, parasites, or random dispersal events.

The ordination analysis yielded an unexpected result. As Figure 8 shows, the freshwater and land molluscan taxa plot as separate groups. However, the data used to run the ordination did not specify which 
taxon was in which group; somehow the program was able to distinguish among them using only the minimum/maximum temperature and precipitation data provided. Just how this happened is not clear.

This separation in ordination space of freshwater and land taxa has important implication for interpreting paleoclimate because the two groups of molluscs (freshwater and land) specify opposite climate signals at the same time, for the same location, because the freshwater and land taxa graphed in Figure 8 can often be found together in the same counties or fossil assemblages. The group of land molluscs in ordination space suggests a warmer and wetter climate while the group of freshwater molluscs suggests a cooler and drier climate. Why land taxa should show a wetter signal than freshwater taxa is not known, but if only land taxa are considered in an analysis, they will suggest a climate which is slightly warmer and wetter. However, if only freshwater taxa are considered in an analysis, they will suggest a climate which is slightly cooler and drier. This produces an inherent bias in paleoecologic studies if the molluscan assemblages studied are not balanced between freshwater and land taxa.

Herein, Miller's (1976) Climate Groups were re-examined using the climate tolerances obtained in this study. Figure 9 shows the plot in ordination space of the taxa common to this study and Miller's (1976) study, with taxa identified by Climate Group. All environmental implications are the same as in Figure 8. The results from the ANOVA analysis suggested that Group-I was colder than Group-II. This is supported by the ordination data as most Group-I taxa plot "below" Group-II taxa. However, Group-II is not represented by many species and by no freshwater species. The lack of freshwater species in Group-II biases its climate signal towards a warmer signal than it otherwise would have. Group-III is supposed to be the wetter Group. However, Group-III is almost all land species and thus it is biased towards a wetter signal than would be the case if more freshwater taxa were present. In other words, the results of the ANOVA can be explained by the proportions of land and freshwater species contained within the Groups, and not as a true climate signal. The analysis of Miller's (1976) Climate Groups is preliminary because only a restricted number of species were analyzed. A more thorough test of all species in Miller's (1976) Climate Groups is needed to examine the validity of climate signals derived from Climate Groups. 


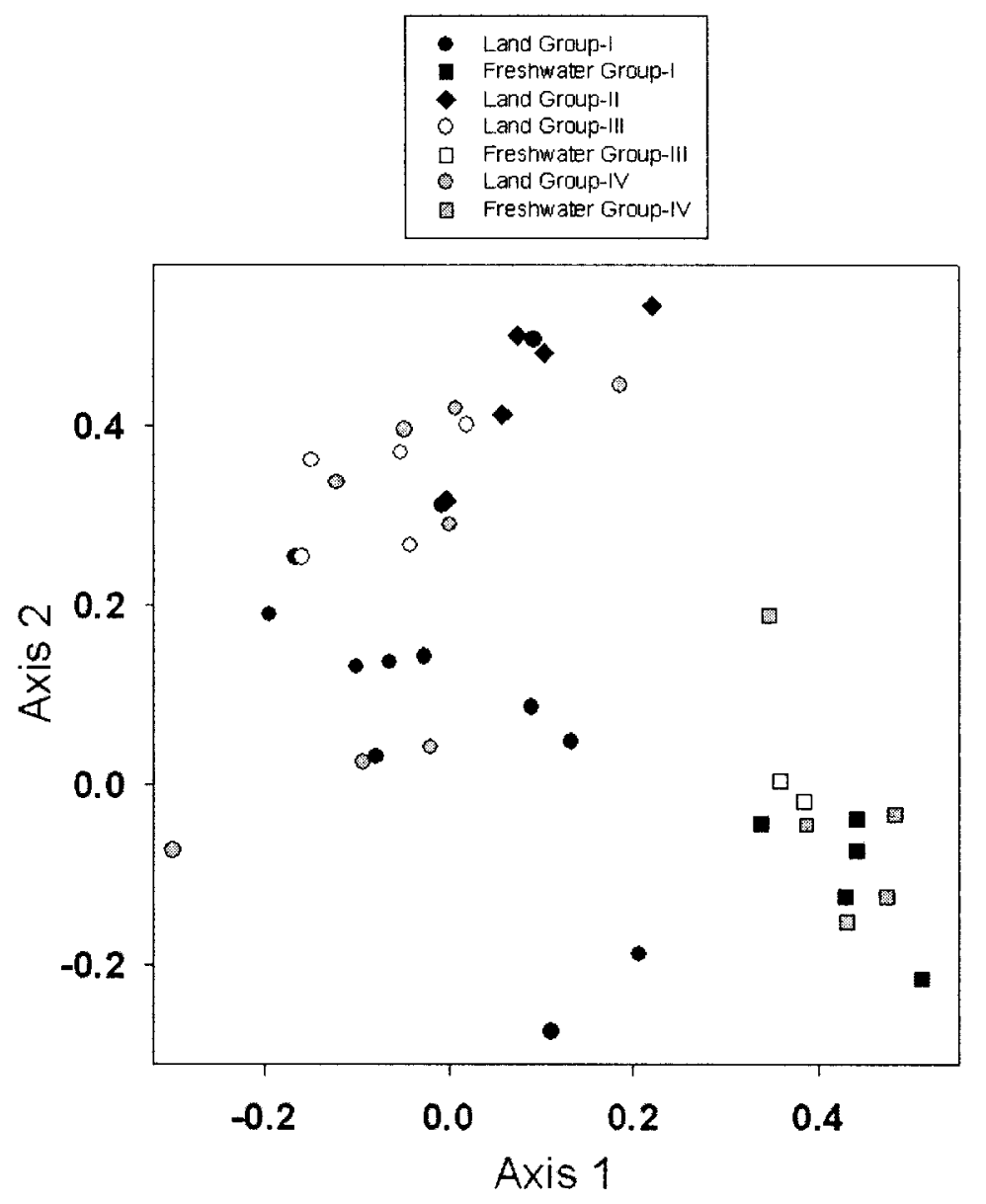

Figure 9. Ordination Space for Climate Groups. Graph of the same ordination space seen in Figure 8, with the same climate implications. Taxa plotted are those common to this study and Miller's (1976) Climate Groups. Circles-land species, squares-freshwater species, diamond-land species of Group-II, black circles and squares-Group-I, white circles and squares-Group-III, gray circles and squaresGroup-IV. 


\section{REFERENCES}

Adams, C. B., 1841, Catalogue of the Mollusca of Middlebury, Vt., and vicinity, with observations: American Journal of Science and Arts, v. 40, no. 2, p. 266-277.

Adams, W. F., and Brady, S. G., 1995, Rediscovery of the aquatic gastropod Helisoma eucosmium (Bartsch, 1908), (Basommatophora: Planorbidae): Brimleyana, v. 22, p. 23-29.

Ahlstrom, E. H., 1930, Mullusks [sic] collected in Bass Island region, Lake Erie: The Nautilus, v. 44, no. 2, p. 44-48.

Alexander, R. C., 1947, Report on the land mollusks of Cape May, N. J.: The Nautilus, v. 61, no. 1, p. 4-6.

---1952, Checklist of New Jersey land snails: The Nautilus, v. 66, no. 2, p. 54-59.

Allen, D. C., and Cheatum, E. P., 1960, Ecological implications of fresh-water and land gastropods in Texas archeological studies: Bulletin of the Texas Archeological Society, v. 31, p. 291-316.

Anderson, T. K., 2005, Land snail diversity in Wind Cave National Park, South Dakota: Western North American Naturalist, v. 65, no. 2, p. 186-195.

Archer, A. F., 1936, The land Mollusca of Cheboygan County, Michigan: Occasional Papers of the Museum of Zoology, no. 340, p. 1-15.

----1939, The ecology of the Mollusca of the Edwin S. George Reserve, Livingston County, Michigan: Occasional Papers of the Museum of Zoology, no. 398, p. 1-24.

Aughey, Samuel, 1877, Catalogue of the land and fresh-water shells of Nebraska: Bulletin of the United States Geological and Geographical Survey of the Territories, v. 3, no. 3, p. 697-704.

Bailey, R. G., 1983, Delineation of ecosystem regions: Environmental Management, v. 7, no. 4, p. 365-373.

-.--1995, Description of the ecoregions of the United States ( $2^{\text {nd }}$ ed., rev.): USDA Forest Service Miscellaneous Publication 1391, $108 \mathrm{p}$.

-----2005, Identifying ecoregion boundaries: Environmental Management, v. 34, suppl. 1, p. s14-s26.

Baker, F. C., 1899a, Notes on the Mollusca of Owasco Lake, N. Y.: The Nautilus, v. 13, no. 5, p. 57-59.

----1899b, Notes on the mollusks of Lilycash Creek: The Nautilus, v. 13, no.3, p. 30-31.

-----1900, On a collection of fresh-water shells from Rhode Island: The Nautilus, v. 13, no. 10, p. 112-113.

----1900, Shell collecting near Rochester, N. Y.: The Nautilus, v. 14, no. 6, p. 69-71.

-.--1904, The molluscan fauna of the Dells of Wisconsin: Transactions of the Academy of Science of Saint Louis, v. 14, no. 2, p. 99-105. 
--- 1905, The molluscan fauna of McGregor, Iowa: Transactions of the Academy of Science of Saint Louis, v. 15, no. 3, p. 249-258.

----1906a, A catalogue of the Mollusca of Illinois: Bulletin of the Illinois State Laboratory of Natural History, v. 7, art. 6, p. 53-136.

----1906b, Notes on a collection of mollusks from the vicinity of Alpena, Michigan: Transactions of the Academy of Science of St. Louis, v. 16, no. 2, p. 1-15.

----1909, Mollusks from Kansas and Oklahoma: The Nautilus, v. 23, no. 7, p. 91-94.

-----1910, Mollusks of Unionville, Conn.: The Nautilus, v. 24, no. 6, p. 68-69.

-----1911a, Mollusks of Wellesley Island and vicinity, St. Lawrence River: The Nautilus, v. 25, no. 6, p. 66-67.

-----1911b, The molluscan fauna of Tomahawk Lake, Wisconsin: Transactions of the Wisconsin Academy of Sciences, Arts, and Letters, v. 17, no. 3, p. 200-246.

----1913, Mollusca from Wyoming Co., N. Y.: The Nautilus, v. 27, no. 5, p. 54.

----1914, Northern Idaho shells: The Nautilus, v. 27, no. 9, p. 104-106.

-----1915, Mollusks from Berrien County, Michigan: The Nautilus, v. 29, no. 4, p. 47.

----1916, The Fresh-water Mollusca of Oneida Lake, New York: The Nautilus, v. 30, no. 1, p. 5-9.

-----1918, Further notes on the Mollusca of Oneida Lake, New York; the mollusks of Lower South Bay: The Nautilus, v. 31, no. 3, p. 81-93.

-----1919, Fresh water Mollusca from Colorado and Alberta: Bulletin of the American Museum of Natural History, v. 41, art. 13, p. 527-539.

----1920, Notes on a small collection of shells from Alaska: The Nautilus, v. 34, no. 2, p. 67-69.

----1922, New Lymnaeas from Wisconsin and Minnesota with notes on shells from the latter state: The Nautilus, v. 36, no. 1, p. 22-25.

----1924, The fauna of the Lake Winnebago region: Transactions of the Wisconsin Academy of Sciences, Arts, and Letters, v. 21, p. 109-146.

----1927, Molluscan associations of White Lake, Michigan: a study of a small inland lake from an ecological and systematic viewpoint: Ecology, v. 8, no. 3, p. 353-370.

----1928, The Mollusca of Chautauqua Lake, New York, with descriptions of a new variety of Ptychobranchus and of Helisoma: The Nautilus, v. 42, no. 2, p. 48-60.

-----1929a, Mollusca from Vermilion and Pelican Lakes, Minnesota, with the description of a new variety of Helisoma corpulenta: The Nautilus, v. 42, no. 3, p.95-97.

-.--1929b, Mollusca from Vermilion and Pelican Lakes, Minnesota, with the description of a new variety of Helisoma corpulenta: The Nautilus, v. 42, no. 4, p. 131-136.

-----1935a, Land and freshwater Mollusca from North Star Lake and vicinity, Itasca County, Minnesota: 
The American Midland Naturalist, v. 16, no. 3, p. 257-274.

-----1935b, Mollusca from Turkey Run State Park, Indiana: The Nautilus, v. 48, no. 3, p. 105-106.

-----1938, New land and freshwater Mollusca from the upper Pliocene of Kansas and a new species of Gyraulus from early Pleistocene strata: The Nautilus, v. 51, no. 4, p. 126-131.

-----1942, Land and fresh water Mollusca of New Hampshire: The American Midland Naturalist, v. 27, no. 1, p. 74-85.

Baker, H. B., 1922, The Mollusca of Dickinson County, Michigan: Occasional Papers of the Museum of Zoology, no. 111, p. 1-44.

----1930, The North American Retinellae: Proceedings of the Academy of Natural Sciences of Philadelphia, v. 82, p. 193-219.

Basch, P. F., Bainer, Philip, and Wilhm, Jerry, 1961, Some ecological characteristics of the molluscan fauna of a typical grassland situation in east central Kansas: The American Midland Naturalist, v. 66, no. 1, p. 178-199.

Baur, A., and Baur, B., 1992, Effect of corridor width on animal dispersal: a simulation study: Global Ecology and Biogeography Letters, v. 2, no. 2, p. 52-56.

Baur, Bruno, and Baur, Anette, 1995, Habitat-related dispersal in the rock-dwelling land snail Chondrina clienta: Ecography, v. 18, no. 2, p. 123-130.

Baxter, Rae, 1987, Mollusks of Alaska, a listing of all mollusks, freshwater, terrestrial, and marine reported from the state of Alaska, with locations of the species types, maximum sizes and marine depths inhabited: Bayside, CA, Shells and Sea Life publishers, $163 \mathrm{p}$.

Beasley, C. W., and Fullington, R. W., 1978, Gastropods of Taylor County, Texas: Sterkiana, no. 69-70, p. $1-2$.

Beetle, Dorothy, 1954, Terrestrial and aquatic mollusks of Albany County, Wyoming: The Nautilus, v. 67, no. 4 , p. 121-129.

Beetle, D. E., 1957, The Mollusca of Teton County, Wyoming: The Nautilus, v. 71, no. 1, p. 12-22.

----1960, Noteworthy records of Wyoming Mollusca: The Nautilus, v. 73, no. 4, p. 155-157.

----1967, Mollusks of the Outer Banks, N. C.: The Nautilus, v. 81, no. 2, p. 61-65.

----1973, A checklist of the land and freshwater mollusks of Virginia: Sterkiana, no. 49, p. 21-35.

----1989, Checklist of recent Mollusca of Wyoming, USA: Great Basin Naturalist, v. 49, no. 4, p. 637645.

Berry, S. S., 1909, The known Mollusca of San Bernardino County, California: The Nautilus, v. 23, no. 6, p. 73-79.

---1910, Mollusks of Unity, Maine: The Nautilus, v. 24, no. 6, p. 61-63.

---1913, A list of Mollusca from the Musselshell Valley, Montana: The Nautilus, v. 26, no. 11. p. 130131. 
----1916a, Additional records of Mollusca from San Bernardino County, California: The Nautilus, v. 30, no. 4 , p. 37-39.

----1916b, Notes on Mollusca of central Montana: The Nautilus, v. 29, no. 11, p. 124-128.

---1937 , Land snails of Kadiak: The Nautilus, v. 50, no. 3, p. 87-88.

----1948, Snails of the Sierra Ancha, Arizona: The American Midland Naturalist, v. 39, no. 1, p. 151-159.

Blakeslee, C. L., [n. d.], The Mollusca of Mendon Ponds, Monroe County, New York: Bulletin of the Buffalo Society of Natural Sciences, v. 17, no. 3, p. 57-59.

Blatchley, W. S., [n. d.], A list of the Mollusca known to occur in Lake Maxinkuckee: Report of the State Geologist, Indiana Department of Geology and Natural Resources $25^{\text {th }}$ Annual Report, p. 248-251.

Boag, D. A., 1986, Dispersal in pond snails: potential role of waterfowl: Canadian Journal of Zoology, v. 64, p. 904-909.

Bogan, A. A., Coney, C. C., and Tarpley, W. A., 1982, Distribution of the Polygyridae (Mollusca: Pulmonata) in Tennessee: Journal of the Tennessee Academy of Science, v. 57, no. 1, p. 16-22.

Bogan, A. E., 2006, Conservation and extinction of the freshwater molluscan fauna of North America, chap. 30 of Sturm, C. F., Pearce, T. A., and Valdés, Ángel, eds., The mollusks a guide to their study, collection, and preservation: American Malacological Society, Boca Raton, FL, Universal Publishers, p. 373-383.

Brady, J. K., and Pearce, T. A., 2007, Terrestrial slugs in strip mined and unmined forested land, Tuscarawas County, Ohio, U. S. A.: Proceedings of the Academy of Natural Sciences of Philadelphia, no. 156, p. 117-122.

Branson, Branley, 1956, Oklahoma gastropods: range extensions, a faunal addition, and a nomenclatural change: Proceedings of the Oklahoma Academy of Science, 37, p. 30-32.

Branson, B. A., 1959, Notes on Oklahoma slugs, with additions to the previously known fauna: The Southwestern Naturalist, v. 4, no. 3, p. 143-147.

----1960a, Gastropoda of the Rob and Bessie Welder Wildlife Foundation Refuge, San Patricio County, Texas: The Southwestern Naturalist, v. 5, no. 3, p. 143-159.

----1960b, The Recent Gastropoda of Oklahoma, iii. Terrestrial species: Pupillidae, Carychiidae, Strobilopsidae and Oligyridae: Proceedings of the Oklahoma Academy of Science, 41, p. 45-69.

----1961a, Notes on some gastropods from northern Louisiana: Proceedings of the Louisiana Academy of Sciences, v. 24, p. 24-30.

-----1961b, Recent Gastropoda of Oklahoma part ii. distribution, ecology and taxonomy of fresh-water species, with description of Helisoma travertina sp. nov.: Oklahoma State University Publication, v. 58, no. 17 , p. 1-72.

----1962a, Some distribution records for Louisiana, Arkansas, and Missouri Gastropoda: Sterkiana, no. 7, p. $5-6$.

--1962b, The recent Gastropoda of Oklahoma, v. terrestrial species, Valloniidae, Achatinidae and Succineidae: Proceedings of the Oklahoma Academy of Science, v. 43, p. 73-87. 
----1963a, Additions to and distributional annotations on the Kansas gastropod fauna: Transactions of the Kansas Academy of Science, v. 66, no. 1, p. 72-75.

-----1963b, The recent Gastropoda of Oklahoma, vi. terrestrial families, Endodontidae and Haplotrematidae. Revisions and Retinella zikmundi Sp. Nov.: Proceedings of the Oklahoma Academy of Science, v. 44, p. 25-41.

----1966, A partial biological survey of the Spring River drainage in Kansas, Oklahoma and Missouri. Part $i$, collecting sites, basic limnological data, and mollusks: Transactions of the Kansas Academy of Science, v. 69 , no. $3-4$, p. $242-293$.

----1969, Snail records from various southern, eastern and middle states: Sterkiana, no. 35, p. 1-4.

----[1970?], Checklist and distribution of Kentucky aquatic gastropods: Department of Fish and Wildlife Resources, Kentucky Fisheries Bulletin 54, 20 p. + figures.

-----1970, Notes on gastropods from Texas, New Mexico, and Mexico: Southwestern Naturalist, v. 14, no. 3, p. 371-372.

-.-1971, Locality records for Oklahoma Mollusca: Sterkiana, no. 41, p. 35-40.

----1973, The recent Gastropoda of Oklahoma, part vii. the Zonitidae: Sterkiana, no. 52, p. 28-44.

----1977, Freshwater and terrestrial Mollusca of the Olympic Peninsula, Washington: The Veliger, v. 19, no. 3, p. 310-330.

-.--1980, Collections of gastropods from the Cascade Mountains of Washington: The Veliger, v. 23, no. 2, p. 171-176.

----1980, The recent Gastropoda of Oklahoma, part viii. the slug families Limacidae, Arionidae, Veronicellidae, and Philomycidae: Proceedings of the Oklahoma Academy of Science, v. 60, p. 29-35.

----1981, The sphaeriacean pelecypods of Oklahoma: Proceedings of the Oklahoma Academy of Science, v. 61 , p. 1-6.

Branson, B. A., and Batch, D. L., 1968, Land snails from Pine and Big Black Mountains, Kentucky: Sterkiana, no. 32, p. 7-17.

‥-1969, Notes on exotic mollusks in Kentucky: The Nautilus, v. 82, no. 3, p. 102-106.

-..--1971, Annotated distribution records for Kentucky Mollusca: Sterkiana, no. 43, p. 1-9.

-.---1981a, Distributional records for gastropods and sphaeriid clams of the Kentucky and Licking River and Tygarts Creek drainages, Kentucky: Brimleyana, no. 7, p. 137-144.

----1981b, The gastropods and sphaeriacean clams of the Dix River System, Kentucky: Transactions of the Kentucky Academy of Science, v. 42, no. 1-2, p. 54-61.

----1982, Molluscan distributional records from the Cumberland River, Kentucky: The Veliger, v. 24, no. 4, p. 351-354.

-----1983, Gastropod and sphaeriacean clam records for streams west of the Kentucky River drainage, Kentucky: Transactions of the Kentucky Academy of Science, v. 44, no. 1-2, p. 8-12.

----1988, Distribution of Kentucky land snails (Mollusca: Gastropoda): Transactions of the Kentucky 
Academy of Science, v. 49 , no. $3-4$, p. 101-116.

Branson, B. A., Batch, D. L., and Call, S. M., 1987, Distribution of aquatic snails (Mollusca: Gastropoda) in Kentucky with notes on fingernail clams (Mollusca: Sphaeriidae: Corbiculidae): Transactions of the Kentucky Academy of Science, v. 48, no. 3-4, p. 62-70.

Branson, B. A., and Branson, M. L., 1991, Gastropod collections from the depauperate fauna of northern California: Transactions of the Kentucky Academy of Science, v. 52, no. 1-2, p. 27-32.

Branson, B. A., and Branson, R. M., 1984, Distributional records for terrestrial and freshwater Mollusca of the Cascade and Coast Ranges, Oregon: The Veliger, v. 26, no. 4, p. 248-257.

Branson, Branley, and Wallen, I. E., 1955, Some further records of snail distribution by counties in Oklahoma: Proceedings of the Oklahoma Academy of Science, v. 36, p. 34-37.

Bretet, Roger, and Carswell, E. J., 1952, A rich locality in the New York City area: The Nautilus, v. 65, no. 3, p. 100-102.

Briscoe, M. S., 1963, A survey of land and freshwater snails in Jefferson County, West Virginia: Sterkiana, no. 9, p. 41-48.

Brooks, S. T., 1931, A list of the land-snails of Pennsylvania with a summary of their distribution: Annals of the Carnegie Museum, v. 22, no. 3-4, p. 313-331.

Brooks, S. T., and Kutchka, G. M., 1937, Occurrence of the family Carychiidæ in West Virginia: Annals of the Carnegie Museum, v. 25, p. 155-161.

----1938, Occurrence of the family Pupillidæ in West Virginia: Annals of the Carnegie Museum, v. 27, p. 63-85.

Brown, R. J., 2007, Freshwater mollusks survive fish gut passage: Arctic, v. 60, no. 2, p. 124-128.

Burch, J. B., 1952, A preliminary list of the Mollusca of Hanover County, Virginia: The Nautilus, v. 66, no. $2,60-63$.

-----1954, The land snails of Henrico County, Virginia: The Nautilus, v. 68, no. 1, p. 30-33.

----1955, The land snails of Hanover, Henrico, and Chesterfield Counties, Virginia: The Virginia Journal of Science, v. 6, p. 154-162.

----1962, How to know the eastern land snails, pictured-keys for determining the land snails of the United States occurring east of the Rocky Mountain divide: Dubuque, IA, Wm. C. Brown, $214 \mathrm{p}$.

-----1982, Freshwater snails (Mollusca: Gastropoda) of North America: United States Environmental Protection Agency report number EPA-600/3-82-026, 294 p.

Burch, P. R., 2002, Mollusks of the Jamse [sic] River Basin: Walkerana, v. 13, no. 29/30, p. 113-122.

Burky, A. J., Way, C. M., Hau, Skippy, and Benbow, M. E., 2000, The occurrence of the freshwater clams, Musculium partumeium (Say) and Pisidium casertanum (Poli) (Bivalvia: Sphaeriidae), in the Hawaiian Islands: Micronesica, v. 33, no. $1 / 2$, p. 161-164.

Bushey, C. J., 1950a, Land snails from Grant County, Indiana: The Nautilus, v. 63, no. 4, p. 119-121.

-----1950b, Land snails from Clifty Falls State Park, Jefferson County, and from Versailles State Park, 
Ripley County, Indiana: The Nautilus, v. 64, no. 2, p. 54-55.

Caffrey, G. W., 1911, The molluscan fauna of Northampton County, Pennsylvania: The Nautilus, v. 25, no. 3, p. 26-29.

Cahn, A. R., and Kemp, J. T., 1929, The terrestrial Mollusca of Turkey Run State Park, Indiana: The Nautilus, v. 43 , no. 2 , p. 66-68.

Call, R. E., 1885, Contributions to a knowledge of the fresh-water Mollusca of Kansas: Bulletin of the Washburn College Laboratory of Natural History, v. 1, no. 2, p. 51-54.

-----1886, Fifth contribution to a knowledge of the fresh-water Mollusca of Kansas: Bulletin of the Washburn College Laboratory of Natural History, v. 1, no. 6, p. 177-184.

----1887, Sixth contribution to a knowledge of the fresh-water Mollusca of Kansas: Bulletin of the Washburn College Laboratory of Natural History, v. 2, no. 8, p. 11-25.

Carpenter, H. F., 1887a, The shell-bearing Mollusca of Rhode Island: The Conchologists' Exchange, v. 1, no. 12 , p. $76-78$.

----1887b, The shell-bearing Mollusca of Rhode Island: The Conchologists' Exchange, v. 2, no. 1, p. 2-3.

----1902, The shell-bearing Mollusca of Rhode Island: The Nautilus, v. 16, no. 2, p. 17-18.

Chadwick, C. H., 1906, List of Wisconsin shells: The Nautilus, v. 20, no. 2, p. 22-24.

Chamberlin, R. V., and Berry, Elmer, 1930, Mollusca from the Henry Mountains and some neighboring points in Utah: Bulletin of the University of Utah, v. 21, no. 2, p. 3-7.

Cheatum, E. P., and Burt, C. E., 1931, An annotated list of the snails of Ellis County, Texas: The American Midland Naturalist, v. 12, no. 9, p. 329-340.

Cheatum, E. P., and Fullington, R. W., 1973, The aquatic and land Mollusca of Texas (part 2), the Recent and Pleistocene members of the Pupillidae and Urocoptidae (Gastropoda) in Texas: Dallas Museum of Natural History Bulletin 1, $67 \mathrm{p}$.

Chichester, L. F., and Getz, L. L., 1973, The terrestrial slugs of northeastern North America: Sterkiana, no. 51, p. 11-42.

Clapp, G. H., 1895, Mollusks of Allegheny Co., Pennsylvania: The Nautilus, v. 8, no. 10, p. 116.

Clark, C. F., 1962, Records of gastropods collected in western Ohio: Sterkiana, no. 6, p. 15-22.

Clench, W. J., 1926, The Physidae of the Au Sable River, Michigan: Papers of the Michigan Academy of Science Arts and Letters, p. 399-403.

Clench, W. J., and Boss, K. J., 1967, Freshwater Mollusca from James River, Va. and a new name for Mudalia of authors: The Nautilus, v. 80, no. 3, p. 99-102.

Clench, W. J., and Russell, H. D., 1940, Freshwater shells of New Hampshire: The Nautilus, v. 54, no. 2, p. 52-53.

Clench, W. J., and Turner, R. D., 1956, Freshwater mollusks of Alabama, Georgia, and Florida from the Escambia to the Suwannee River: Bulletin of the Florida State Museum Biological Sciences, v. 1, no. 3, p. 99-239. Available from: http://fulltext10.fcla.edu/cgi/t/text/text- 
$\mathrm{idx} ? \mathrm{c}=$ feol\&idno=UF00002260\&Format $=$ pdf (accessed May 4, 2009).

Counts, C. L., III, 1982, Occurrence and distribution of land snails of the family Polygyridae (Mollusca: Gastropoda: Pulmonata) in West Virginia: Brimleyana, no. 8, p. 145-157.

Cowie, R. H., 1997, Catalog and bibliography of the nonindigenous nonmarine snails and slugs of the Hawaiian Islands: Bishop Museum Occasional Papers 50, 66 p.

Cowie, R. H., Hayes, K. A., Tran, C. T., and Meyer, W. M., III, 2008, The horticultural industry as a vector of alien snails and slugs: widespread invasions in Hawaii: International Journal of Pest Management, $v$. 54 , no. 4 , p. 267-276.

Currier, A. O., 1865, Catalogue of the Mollusca of Grand Rapids, Michigan: American Journal of Conchology, v. 1, no. 4, p. 292-296.

Cvancara, A. M., 1983, Aquatic mollusks of North Dakota: North Dakota Geological Survey Report of Investigation $78,141 \mathrm{p}$.

Dall, W. H., 1885, Notes on some Floridian land and fresh-water shells with a revision of the Auriculacea of the eastern United States: Proceedings of the United States National Museum, v. 8, p. 255-289+ plates.

-..-1905, Land and fresh water mollusks of Alaska and adjoining regions, in Merriam, C. H., ed., Alaska v. 13, Harriman Alaska Expedition, Doubleday, Page \& Co., NY, p. 1-171.

----1917, Notes on boreal land and freshwater shells: The Nautilus, v. 31, no. 1, p. 12-13.

Daniels, L. E., 1909, Records of Minnesota mollusks: The Nautilus, v. 22, no. 11, p. 119-121.

----1920, Shells from Jamestown, North Dakota: The Nautilus, v. 34, no. 1, p. 29.

Darwin, Charles, 1882 , On the dispersal of freshwater bivalves: Nature, v. 25 , p. 529-530.

Davis, A. J., Jenkinson, L. S., Lawton, J. H., Shorrocks, Bryan, and Wood, Simon, 1998, Making mistakes when predicting shifts in species range in response to global warming: Nature, v. 391, p. 783-786.

Dawley, Charlotte, 1955, Minnesota land snails: The Nautilus, v. 69, no. 2, p. 56-62.

--.-1965, Checklist of freshwater mollusks of North Carolina: Sterkiana, no. 19, p. 35-39.

Devore, C. H., 1975, The molluscan fauna of the Illinoian butler spring sloth locality from Meade County, Kansas, in Smith, G. R., and Friedland, N. E., eds., Studies on Cenozoic paleontology and stratigraphy in honor of Claude W. Hibbard: University of Michigan, The Museum of Paleontology Papers on Paleontology 12, p. 19-28.

Dexter, R. W., 1950, Distribution of the mollusks in a basic bog lake and its margins: The Nautilus, v. 64 , no. 1, p. 19-26.

----1953, The mollusks inhabiting some temporary pools and ponds in Illinois and Ohio: The Nautilus, v. 67 , no. 1 , p. 26-33.

----1956, Comparison of the gastropod fauna in the drainage systems of Champaign County, Illinois: The American Midland Naturalist, v. 55, no. 2, p. 363-368.

Dillon, R. T., Jr., 2009, Empirical estimates of reproductive isolation among the Physa species of South Carolina (Gastropoda: Pulmonata: Basommatophora): The Nautilus, v. 123, no. 4, p. 276-281. 
Dillon, R. T., Jr., and Herman, J. J., 2009, Genetics, shell morphology, and life history of the freshwater pulmonate limpets Ferrissia rivularis and Ferrissia fragilis: Journal of Freshwater Ecology, v. 24, no. 2, p. 261-271.

Dillon, R. T., Jr., Robinson, J. D., Smith, T. P., and Wethington, A. R., 2005, No reproductive isolation between freshwater pulmonate snails Physa virgata and P. acuta: The Southwestern Naturalist, v. 50, no. 4, p. 415-422.

Dillon, R. T., Jr., Robinson, J. D., and Wethington, A. R., 2007, Empirical estimates of reproductive isolation among the freshwater pulmonate snails Physa acuta, P. pomilia, and $P$. hendersoni: Malacologia, v. 49 , no. 2 , p. $283-292$.

Dillon, R. T., Jr., Wethington, A. R., Rhett, J. M., and Smith, T. P., 2002, Populations of the European freshwater pulmonate Physa acuta are not reproductively isolated from American Physa heterostropha or Physa integra: Invertebrate Biology, v. 121, no. 3, p. 226-234.

Dirrigl, F. J., Jr., and Bogan, A. E., 1995-1996, Revised checklist of the terrestrial gastropods of New Jersey (Mollusca: Gastropoda): Walkerana, v. 8, no. 20, p. 127-138.

Dourson, Dan, 2007, A selected land snail compilation of the Central Knobstone Escarpment on Furnace Mountain in Powell County Kentucky: Journal of the Kentucky Academy of Science, v. 68, no. 2, p. 118131.

Dourson, D. C., and Beverly, Joel, 2008, Diversity, substrata divisions and biogeographical affinities of land snails at Bad Branch State Nature Preserve, Letcher County, Kentucky: Journal of the Kentucky Academy of Science, v. 69, no. 2, p. 101-116.

Dourson, Dan, and Feeman, Kim, 2006, A survey of terrestrial Mollusca in selected areas of the Land Between the Lakes National Recreation area: Journal of the Kentucky Academy of Science, v. 67, no. 1, p. 9-18.

Dundee, D. S., and Watt, Patti, 1961, Louisiana land snails with new records: The Nautilus, v. 75, no. 2, p. 79-83.

Ehlers, E. G., 1972, The interpretation of geological phase diagrams: New York, NY, Dover Publications, $280 \mathrm{p}$.

Einsohn, Bruce, 1981, New records of land Mollusca in New York City: The Nautilus, v. 95, no. 2, p. 8283.

Elrod, M. J., 1902a, Collecting shells in Montana: The Nautilus, v. 15, no. 9, p. 103-104.

----1902b, Collecting shells in Montana: The Nautilus, v. 15, no. 10, p. 110-112.

Eyerdam, W. J., 1933, A biological collecting excursion to the Aleutian Islands: The Nautilus, v. 46, no. 4, p. 124-128.

-.---1939, Land snails collected at Uganik Bay, Kodiak Island: The Nautilus, v. 53, no. 2, p. 61-64.

--.-1940, Further notes on land shells from Kodiak and nearby islands: The Nautilus, v. 53, no. 4, p. 131133.

Ferriss, J. H., 1906, Mollusks of Oklahoma: The Nautilus, v. 20, no. 2, p. 16-17. 
Flowers, J. R., and Miller, G. C., 1993, New molluscan (Gastropoda and Bivalvia) records for the Nuese River basin, North Carolina: Brimleyana, v. 19, p. 61-64.

Franzen, D. S., and Leonard, A. B., 1942, A preliminary survey of the Mollusca of Kingman County, Kansas: Transactions of the Kansas Academy of Science, v. 45, p. 334-343.

Freed, Sam, 1957, Land and fresh water mollusks of Union County, New Jersey: The Nautilus, v. 70, no. 4, p. 135-136.

Frest, T. J., 1987, Final report lowa Pleistocene snail project 1987: University of Washington, Division of Geology and Paleontology, Burke Museum DB-10,39 p. Available from: http://files.dnr.state.mn.us/eco/nongame/projects/consgrant_reports/1987/1987_frest.pdf (accessed May 4, 2009).

Frest, T. J., and Johannes, E. J., 1993, Mollusc survey of the Minidoka Dam area, upper Snake River, Idaho: U. S. Department of the Interior, Bureau of Reclamation, Boise, ID, contract \# 1425-2-PG-10$16780,36 \mathrm{p}$.

-.--1997a, Land snail survey of the lower Salmon River drainage, Idaho: Idaho Bureau of Land Management Technical Bulletin 97-18, 142 p. + tables, appendices and figures. Available from: www.blm.gov/pgdata/etc/medialib/blm/id/publications/technical_bulletins/tb_9718.Par.36585.File.dat/entiredoc.pdf (accessed May 4, 2009).

-----1997b, Land snails of the Lucile Caves ACEC: Idaho Bureau of Land Management Technical Bulletin 97-16, 9 p. + tables, appendices and figures. Available from: http://www.blm.gov/pgdata/etc/medialib/blm/id/publications/technical_bulletins/tb_9716.par.79301.File.dat/entiredoc.pdf (accessed May 4, 2009).

-.--2002, Land snail survey of the Black Hills National Forest, South Dakota and Wyoming, summary report, 1991-2001: USDA Forest Service, Final Report Contract \#43-67TO-8-1085, 127 p. + tables, appendices and figures.

Frye, J. C., and Leonard, A. B., 1967, Buried soils, fossil mollusks, and late Cenozoic paleoenvironments, in Teichert, Curt, and Yochelson, E. L., eds., Essays in Paleontology and Stratigraphy, R. C. Moore Commemorative Volume: University Press of Kansas, Department of Geology, University of Kansas special publication 2, p. 429-444.

Fullington, R. W., and Pratt, W. L., Jr., 1974, The aquatic and land Mollusca of Texas (part 3), the Helicinidae, Carychiidae, Achatinidae, Bradybaenidae, Bulimulidae, Cionellidae, Haplotrematidae, Helicidae, Oreohelicidae, Spiraxidae, Streptaxidae, Strobilopsidae, Thysanophoridae, Valloniidae (Gastropoda) in Texas: The Dallas Museum of Natural History Bulletin 1, 48 p.

Fürsich, F. T., and Aberhan, Martin, 1990, Significance of time-averaging for palaeocommunity analysis: Lethaia, v. 23, p. 143-152.

Gansecki, C., A., Mahood, G. A., and McWilliams, M., 1998, New ages for the climactic eruptions at Yellowstone: single-crystal ${ }^{40} \mathrm{Ar}{ }^{39} \mathrm{Ar}$ dating identifies contamination: Geology, v. 26, no. 4, p. 343-346.

Getz, L. L., 1962, Localities for New Hampshire land mollusks: The Nautilus, v. 76, no. 1, p. 25-28.

Gleason, H. A., 1926, The individualistic concept of the plant association: Bulletin of the Torrey Botanical Club, v. 53, no. 1, p. 7-26.

Goodrich, Calvin, 1931, Mollusks of Keweenaw County, Michigan: Occasional Papers of the Museum of Zoology, no. 233, p. 1-9. 
-----1939, Part I. the gastropods and the Sphaeriidae, in Goodrich, Calvin, and van der Schalie, Henery, eds., Aquatic mollusks of the Upper Peninsula of Michigan: Museum of Zoology Miscellaneous Publications, no. 43, p. 7-34.

---1944a, Certain operculates of the Coosa River: The Nautilus, v. 58, no. 1, p. 1-10.

$----1944 b$, Pulmonates of the Coosa River: The Nautilus, v. 58, no. 1, p. 11-15.

Goodrich, Calvin, and van der Schalie, Henry, 1944, A revision of the Mollusca of Indiana: The American Midland Naturalist, v. 32, no.2, p. 257-326.

Gordon, M. E., 1985, Mollusca of Frog Bayou, Arkansas: The Nautilus, v. 99, no. 1, p. 6-9.

Gordon, M. E., Chordas, S. W., III, Harp, G. L., and Brown, A. V., 1993-1994, Aquatic Mollusca of the White River National Wildlife Refuge, Arkansas, U. S. A.: Walkerana, v. 7, no. 17/18, p. 1-9.

Greger, D. K., 1915, The Gastropoda of Payne County, Oklahoma: The Nautilus, v. 29, no. 8, p. 88-90.

Grimm, Wayne, 1959a, Land snails from Maryland and Virginia: The Nautilus, v. 73, no. 1, p. 21-22.

----1959b, Land snails of Carroll County, Maryland: The Nautilus, v. 72, no. 4, p. 122-127.

Grimm, F. W., 1961, Land snails from the upper Patuxent estuary margin (Maryland): The Nautilus, v. 74, no. 3, p. 106-109.

----1971, Annotated checklist of the land snails of Maryland and the District of Columbia: Sterkiana, no. 41, p. 51-57.

-...-1975, A review of Succinea wilsoni a coastal marsh snail of eastern North America: The Nautilus, $v$. 89 , no. 2 , p. 39-43.

Ginsburg, N. S., Foote, K. E., and Dahlberg, R. E., 1983, Atlas of the United States: Chicago, IL, Rand Mc.Nally \& Company, 192 p.

Haas, F., 1954, Non-marine mollusks from the Pacific slope of North America: The Nautilus, v. 67, no. 3, p. 94-96.

Hammer, Øyvind, and Harper, D. A. T., 2006, Paleontological data analysis: Malden, MA, Blackwell, 351 p.

Hanna, G. D., 1909, The Mollusca of Douglas County, Kansas. Gasteropoda: The Nautilus, v. 23, no. 7, p. 94-96.

---1925 , Some land shells from the Aleutian Islands, Alaska: The Nautilus, v. 38, no. 4, p. 122-125.

-..-1956, Land and freshwater mollusks of the Arctic Slope, Alaska: The Nautilus, v. 70, no. 1, p. 4-10+ plates.

Harland, W. B., Armstrong, R. L., Cox, A. V., Craig, L. E., Smith, A. G., and Smith, D. G., 1990, A geologic time scale 1989: Cambridge, UK, Cambridge University Press, 263 p.

----1998, The molluscan community of Oneida Lake, New York: Journal of Freshwater Ecology, v. 13, no. 2 , p. 207-211. 
Harman, W. N., and Berg, C. O., 1970, Fresh-water Mollusca of the Finger Lakes region of New York: The Ohio Journal of Science, v. 70, no. 3, p. 146-150.

Harman, W. N., and Forney, J. L., 1970, Fifty years of change in the molluscan fauna of Oneida Lake, New York: Limnology and Oceanography, v. 15 , no. 3, p. 454-460.

Harper, G. W., and Wetherby, A. G., 1876, Catalogue of the land and fresh water Mollusca found in the immediate vicinity of Cincinnati, O: Cincinnati, $\mathrm{OH}$, James Barclay, English and German Printing House, $5 \mathrm{p}$.

Heard, W. H., 1963, Survey of the Sphaeriidae (Mollusca; Pelecypoda) of the southern United States: Louisiana Academy of Sciences, v. 26, p. 102-120.

Heilman, R. A., 1951, The mollusks of Dauphin County, Pennsylvania: The Nautilus, v. 64, no. 3, p. 100101.

-.--1952, The mollusks of Berks County, Pennsylvania: The Nautilus, v. 65, no. 3, p. 103-104.

Heilman, R. A., and MacMillan, G. K., 1958, Mollusks of Lebanon Co., Pennsylvania: The Nautilus, v. 72 , no. 2 , p. $58-60$.

Henderson, J. B., 1907a, A list of land and fresh-water shells of Yemassee, South Carolina: The Nautilus, v. 21 , no. 1 , p. 7-8.

----1907b, Mollusks of Cazenovia, N. Y.: The Nautilus, v. 20, no. 9, p. 97-98.

Henderson, Junius, 1907, The Mollusca of Colorado. Part ii: University of Colorado Studies, v. 4, p. 167185.

----1912, The Mollusca of Colorado. Part iii: University of Colorado Studies, v. 9, p. 53-63.

-.-1918, A mollusk hunt in Wyoming: The Nautilus, v. 32, no. 2, p. 40-47.

-..-1927, Some South Dakota Mollusca: The Nautilus, v. 41, no. 1, p. 19-20.

Henderson, Junius, and Daniels, L. E., 1917, Hunting Mollusca in Utah and Idaho in 1916: Proceedings of the Academy of Natural Sciences of Philadelphia, p. 48-81.

Hendricks, Paul, Maxell, B. A., and Lenard, Susan, 2006, Land mollusk survey on USFS northern region lands: USDA Forest Service, Northern Region, Montana Natural Heritage Program, Helena, MT, 11 p. + appendices. Available from: http://mtnhp.org/reports/USFS_Mollusks.pdf (accessed May 4, 2009).

Hibbard, C. W., 1949, Techniques of collecting microvertebrate fossils: Contributions of the Museum of Paleontology, University of Michigan, v. 8, no. 2, p. 7-19.

Hinkley, A. A., 1904a, List of Alabama shells collected in October and November, 1903: The Nautilus, v. 18 , no. 4 , p. $37-45$.

----1904b, List of Alabama shells collected in October and November, 1903: The Nautilus, v. 18, no. 5, p. 54-57.

-.--1906a, Some shells of Mississippi and Alabama: The Nautilus, v. 20, no. 3, p. 34-36.

----1906b, Some shells of Mississippi and Alabama: The Nautilus, v. 20, no. 4, p. 40-44. 
-----1915, New fresh-water shells from the Ozark Mountains: Proceedings of the United States National Museum, v. 49 , no. 2126 , p. $587-589+$ plate.

----1919, Mollusca found in the vicinity of Dubois, Illinois: The Nautilus, v. 33, no. 1, p. 14-17.

Hoff, C. C., 1962, Some terrestrial Gastropoda from New Mexico: The Southwestern Naturalist, v. 7, no. 1, p. 51-63.

Hotopp, K. P., 2002, Land snails and soil calcium in central Appalachian Mountain forest: Southeastern Naturalist, v. 1, no. 1, p. 27-44.

Hotopp, Ken, and Pearce, T. A., 2007, Land snails in New York: statewide distributions and talus site faunas: New York State Biodiversity Research Institute, New York State Museum, final report for contract \#NYHER 041129, 91 p.

Hubbard, J. W., and Smith, Sanderson, 1865, Catalogue of the Mollusca of Staten Island, N. Y.: Annals of the Lyceum of Natural History of New York, v. 8, no. 4-5, p. 151-154.

Hubricht, Leslie, 1950, The Polygyridae of Pittsylvania County, Virginia: The Nautilus, v. 64, no. 1, p. 69.

-----1951, The Limacidae and Philomycidae of Pittsylvania County, Virginia: The Nautilus, v. 65, no. 1, p. $20-22$.

-----1952, The land snails of Pittsylvania County, Virginia: The Nautilus, v. 66, no. 1, p. 10-13.

----1953, The Zonitidae of Pittsylvania County, Virginia: The Nautilus, v. 67, no. 1, p. 22-24.

-----1960, Distribution records of land snails in the southeastern United States: Sterkiana, no. 2, p. 9-11.

----1963a, Some land snail records from Louisiana: Sterkiana, no. 10, p. 1-3.

----1963b, Some Succineidae, with a new species: The Nautilus, v. 76, no. 4, p. 135-138.

----1964a, Land snails from the caves of Kentucky, Tennessee and Alabama: The National Speleological Society Bulletin, v. 26, no. 1, p. 33-36.

---1964b, The land snails of Georgia: Sterkiana, no. 16, p. 5-10.

----1965, The land snails of Alabama: Sterkiana, no. 17, p. 1-5.

-----1967, Some land snail records from Oklahoma and Arkansas: The Nautilus, v. 81, no. 2, p. 65-67.

----1968a, The land snails of Kentucky: Sterkiana, no. 32, p. 1-6.

----1968b, The land snails of Mammoth Cave National Park, Kentucky: The Nautilus, v. 82, no. 1, p. 2428.

----1970, The land snails of North Carolina: Sterkiana, no. 39, p. 11-15.

----1971a, The land snails of South Carolina: Sterkiana, no. 41, p. 41-44.

-----1971b, Additional land snails from North Carolina: Sterkiana, no. 41, p. 44.

----1971c, The land snails of Virginia: Sterkiana, no. 42, p. 41-45. 
-----1972a, Land snail records from Missouri: Sterkiana, no. 45, p. 34-35.

----1972b, The land snails of Arkansas: Sterkiana, no. 46, p. 15-17.

----1973, The land snails of Tennessee: Sterkiana, no. 49, p. 11-17.

----1977, The land snails of Mississippi: Sterkiana, no. 67-68, p. 1-4.

-.--1983, Five new species of land-snails from the southeastern United States with notes on other species: Gastropodia, v. 2, no. 2, p. 13-19.

----1985, The distributions of the native land mollusks of the eastern United States: Fieldiana, Zoology, Field Museum of Natural History New Series 24, publication 1359, 191 p.

Hutchinson, G. E., 1957, Concluding remarks: Cold Spring Harbor Symposia on Quantitative Biology, v. 22, p. 415-427.

----1978, An introduction to population ecology: New Haven, CT, Yale University Press, 260 p.

Ideker, Joe, 1979, The associated gastropod fauna of the Santa Ana National Wildlife Refuge with notes on a colony of the snail Helicina orbiculata: Southwestern Naturalist, v. 24, p. 687-689.

Ingersoll, Ernest, 1877, On a collection of Mollusks from Utah and Colorado: Davenport Academy of Natural Sciences, v. 2, p. 130-135.

International Commission on Zoological Nomenclature, 1999, International code of zoological nomenclature (English text, $4^{\text {th }}$ ed.): London, UK, The International Trust for Zoological Nomenclature, $p$. $1-126$.

Integrated Taxonomic Information System, first accessed 2006, Integrated Taxonomic Information System [internet]: Available from: http://www.itis.gov (accessed July 2006 through August 2009).

Jacobson, M. K., and Emerson, W. K., 1961, Shells of the New York City area: Larchmont, NY, Argonaut Books, $142 \mathrm{p}$.

Jass, J. P., 1980, Terrestrial gastropods at the UWM Cedar-Sauk Field Station: The University of Wisconsin-Milwaukee Field Stations Bulletin, v. 13, no. 1, p. 1-3.

----1986, Supplemental distribution records for Wisconsin terrestrial gastropods: Transactions of the Wisconsin Academy of Sciences, Arts and Letters, v. 74, p. 105-107.

-----2004, Distributions of gastropods in Wisconsin: Milwaukee Public Museum Contributions in Biology and Geology 99, $28 \mathrm{p}$.

Jass, Joan, and Glenn, Jeanette, 2002, Milwaukee River molluscan fauna in Milwaukee County, Wisconsin: Journal of Freshwater Ecology, v. 17, no. 1, p. 165-167.

Johnson, C. W., 1910, Shells of Mt. Equinox, Vermont: The Nautilus, v. 24, no. 6, p. 72.

Jokinen, E. H., 1983, The freshwater snails of Connecticut: State Geological and Natural History Survey of Connecticut Bulletin 109, 83 p.

----1992, The freshwater snails (Mollusca: Gastropoda) of New York state: New York State Museum Bulletin 482, 112 p. 
-----2005, Pond mollusks of Indiana Dunes National Lakeshore: then and now: American Malacological Bulletin, v. 20, no. 1/2, p. 1-9.

Jones, D. T., 1941, Mollusks in the vicinity of Ames, lowa: Iowa State Journal of Science, v. 15, no. 2, p. 183-188.

Keyes, C. R., 1888, An annotated catalogue of the Mollusca of Iowa: Bulletin of the Essex Institute, v. 20, no. $4-6$, p. $61-83$.

Krebs, C. J., 1999, Ecological methodology (2 ${ }^{\text {nd }}$ ed.): Menlo Park, CA, Addison Wesley Longman, 620 p.

Lapham, J. A., 1860, A list of shells of the state of Wisconsin: Proceedings of the Academy of Natural Sciences of Philadelphia, v. 12, p. 154-156.

Laursen, J. R., Averbeck, G. A., and Conboy, G. A., 1989, A final report to the Minnesota Department of Natural Resources: Non-Game Division, preliminary survey of pulmonate snails of central Minnesota, [38 p.] Available from:

http://files.dnr.state.mn.us/eco/nongame/projects/consgrant_reports/1989/1989_laursen_etal.pdf (accessed May 4, 2009).

Laursen, J. R., Averbeck, G. A., Conboy, G. A., and Stromberg, B. E., 1992, Survey of pulmonate snails of central Minnesota. I. Lymnaeidae: Journal of Freshwater Ecology, v. 7, no. 1, p. 25-33.

Lee, H. G., 2006, Landsnails of Claiborne Bluff: American Conchologist, v. 34, no. 3, p. 30-31.

-----2008, Five years later new discoveries continue in the Vermont "reunion roundup": The Shell-OGram, v. 49-2, p. 3-6.

Lehnert, C., 1885, A list of recent land and fresh-water mollusks of the District of Columbia and vicinity: The Pastime, v. 3, no. 8, p. 5-8.

Leonard, A. B., 1946, Three new pupillids from the lower Pleistocene of central and southwestern Kansas: The Nautilus, v. 60 , no, 1, p. $20-24$.

-.--1950, A Yarmouthian molluscan fauna in the midcontinent region of the United States: University of Kansas Paleontological Contributions 8, 48 p.

-----1959, Handbook of gastropods in Kansas: University of Kansas Museum of Natural History Miscellaneous Publications 20, $224 \mathrm{p}$.

Leonard, A. B., and Goble, C. R., 1952, Mollusca on the University of Kansas Natural History Reservation: The University of Kansas Science Bulletin, v. 34, pt. 2, no. 16, p. 1013-1055.

Leonard, A. B., and Leonard, A. E., 1946, Mollusca from Greenwood County, Kansas: The University of Kansas Science Bulletin, v. 31, pt. 1, no. 6, p. 115-122.

Leonard, A. E., 1943, The Mollusca of Meade and Clark Counties, Kansas: Transactions of the Kansas Academy of Science, v. 46, p. 226-240.

Lermond, N. W., 1914, Additions to the list of Maine Mollusca: The Nautilus, v. 28, no. 2, p. 18-20.

Levi, L. R., and Levi, H. W., 1950, New records of land snails from Wisconsin: The Nautilus, v. 63, no. 4, p. $131-138$. 
Lewis, James, 1860, Catalogue of the Mollusks in the vicinity of Mohawk, New York: Proceedings of the Academy of Natural Sciences of Philadelphia, v. 12, p. 17-19.

----1876, Fresh-water and land shells: Fauna of Alabama, supplement 4, p. 1-42.

Liechti, P. M., and Mackie, G. L., 1977, Sphaeriidae records from Kansas: Technical Publications of the State Biological Survey of Kansas, v. 4, p. 15-16.

Lowe, H. N., 1917, Shell collecting in the Sierra Nevadas: The Nautilus, v. 30, no. 9, p. 92-95.

Lutz, Louis, 1949, A check list of the land snails of Oklahoma: Proceedings of the Oklahoma Academy of Science for 1949, v. 30, p. 32-35.

----1950, A list of the land Mollusca of Claiborne County, Tennessee, with description of a new subspecies of Triodopsis: The Nautilus, v. 63, no. 3, p. 99-105.

Lysne, Steven, and Koetsier, Peter, 2006, Growth rate and thermal tolerance of two endangered Snake River snails: Western North American Naturalist, v. 66, no. 2, p. 230-238.

Lysne, S. J., and Clark, W. H., 2009, Mollusk survey of the lower Bruneau River, Owyhee County, Idaho, U. S. A.: American Malacological Bulletin, v. 27, no. 1/2, p. 167-172.

Lysne, S. J., and Pierce, Ron, 2009, Mollusk survey of Crystal Creek-Spring Creek Ranches, Blaine County, Idaho, USA: Ellipsaria, v. 11, no. 1, p. 20.

MacMillan, G. K., 1949, The land snails of West Virginia: Annals of the Carnegie Museum, v. 31, art. 7, p. 89-239.

Magurran, A. E., 2004, Measuring biological diversity: Malden, MA, Blackwell, 256 p.

Malone, C. R., 1965, Dispersal of aquatic gastropods via the intestinal tract of water birds: The Nautilus, v. 78 , no. 4, p. 135-139.

Marcolini, Federica, and Martin, R. A., 2008, Mosaic evolution in first lower molars of Pliocene Ogmodontomys (Rodentia: Arvicoliidae) from the Meade Basin of southwestern Kansas (USA): Neue Jahrbuch fur Geologie und Paläontologie Abhandlung, v. 249, no. 3, p. 313-332.

Marsh, W. A., 1887, Brief notes on the land and fresh-water shells of Mercer Co., Ill.: The Conchologists' Exchange, v. 2, no. 6, p. 80-81.

-----1888a, Brief notes on the land and fresh-water shells of Mercer Co., III.: The Conchologists' Exchange, v. 2, no. 7, p. 90-92.

----1888b, Brief notes on the land and fresh-water shells of Mercer Co., Ill.: The Conchologists' Exchange, v. 2, no. 8, p. 103-104.

-.--1888c, Brief notes on the land and fresh-water shells of Mercer Co., Ill.: The Conchologists' Exchange, v. 2, no. 9, p. 110-111.

Martin, R. A., and Fairbanks, K. B., 1999, Cohesion and survivorship of a rodent community during the past 4 million year in southwestern Kansas: Evolutionary Ecology Research, v. 1, p. 21-48.

Martin, R. A., Peláez-Campomanes, Pablo, Honey, J. G., Fox, D. L., Zakrzewski, R. J., Albright, L. B., Lindsay, E. H., Opdyke, N. D., and Goodwin, H. T., 2008, Rodent community change at the PliocenePleistocene transition in southwestern Kansas and identification of the Microtus immigration event on the 
Central Great Plains: Palaeogeography, Palaeoclimatology, Palaeoecology, v. 267, p. 196-207.

Martin, R. E., 1999, Taphonomy a process approach: Cambridge, UK, Cambridge University Press, 508 p.

Martin, S. M., 1999, Freshwater snails (Mollusca: Gastropoda) of Maine: Northeastern Naturalist, v. 6, no. 1, p. 39-88.

-----2000, Terrestrial snails and slugs (Mollusca: Gastropoda) of Maine: Northeastern Naturalist, v. 7, no. 1, p. 33-88.

McCune, Bruce, and Mefford, M. J., 2006, PC-ORD multivariate analysis of ecological data (v. 5): MjM Software, Gleneden Beach, OR.

McDonnell, R. J., Paine, T. D., and Gormally, M. J., 2009, Slugs a guide to the invasive and native fauna of California: University of California Division of Agriculture and Natural Resources Publication 8336, 21 p. Available from: http://ucanr.org/freepubs/docs/8336.pdf (accessed May 13, 2009).

McKenna, M. C., Bleefeld, A. R., and Mellett, J. S., 1994, Microvertebrate collecting: large-scale wet sieving for fossil Microvertebrates in the field, in Leiggi, Patrick, and May, Peter, eds., Vertebrate paleontological techniques (v. 1): Cambridge, UK, Cambridge University, p. 93-111.

McMahon, R. F., and Payne, B. S., 1980, Variation of thermal tolerance limits in populations of $P h y s a$ virgata Gould (Mollusca: Pulmonata): The American Midland Naturalist, v. 103, no. 2, p. 218-230.

McMillan, M. E., Heller, P. L., and Wing, S. L., 2006, History and causes of post-Laramide relief in the Rocky Mountain orogenic plateau: Geological Society of America Bulletin, v. 118, no. 3/4, p. 393-405.

Meretsky, V. J., North E. G., and Stevens, L. E., 2002, Kanab ambersnail and other terrestrial snails in south central Utah: Western North American Naturalist, v. 62, no. 3, p. 307-315.

Metcalf, A. L., 1984a, Distribution of land snails of the San Andres and Organ Mountains, southern New Mexico: The Southwestern Naturalist, v. 29, no. 1, p. 35-44.

----1984b, Land snails (Gastropoda: Pulmonata) from Cimarron County, Oklahoma: The Texas Journal of Science, v. 36, no. 1, p. 53-64.

-.--1997, Land snails of New Mexico from an historical zoogeographic point of view, in Metcalf, A. L., and Smartt, R. A., eds., Land snails of New Mexico, New Mexico Museum of Natural History and Science Bulletin 10, p.71-108.

Metcalf, A. L., and Smartt, R. A., 1997, Appendix B, in Metcalf, A. L., and Smartt, R. A., eds., Land snails of New Mexico: New Mexico Museum of Natural History and Science Bulletin 10, p. 139-145.

Metcalf, A. L., and Smartt, R. A.; Dillon, T. J., and Metcalf, A. L., 1997, Appendix A, in Metcalf, A. L., and Smartt, R. A., eds., Land snails of New Mexico: New Mexico Museum of Natural History and Science Bulletin 10, p. 128-138.

Miles, C. D., 1958, The family Succineidae (Gastropoda: Pulmonata) in Kansas: The University of Kansas Science Bulletin, v. 38, pt. 2, no. 24, p. 1499-1543.

Miller, B. B., 1975, A sequence of radiocarbon-dated Wisconsinan nonmarine molluscan faunas from southwestern Kansas-northwestern Oklahoma, in Smith, G. R., and Friedland, N. E., eds., Studies on Cenozoic paleontology and stratigraphy in honor of Claude W. Hibbard: University of Michigan, The Museum of Paleontology Papers on Paleontology 12, p. 9-18. 
-.-1976, The late Cenozoic molluscan succession in the Meade County, Kansas area, in Bayne, C. K., ed., Stratigraphy and Faunal Sequence-Meade County, Kansas, $24^{\text {th }}$ Annual Meeting, Midwestern Friends of the Pleistocene Guidebook Series 1, p. 73-85.

Miller, B. B., and Eshelman, R. E., 1985, Pleistocene molluscs from Jewell County, Kansas, associated with the Hartford Ash (0.706 MYBP): Journal of Paleontology, v. 59, no. 3, p. 649-655.

Miller, B. B., and Hibbard, C. W., 1972, Recent Mollusca of Ellsworth County, Kansas: Sterkiana, no. 46, p. 11-14.

Miller, B. B., and Kay, W. T., 1981, Gastropods from the Kanopolis local fauna (Yarmouthian?), Ellsworth County, Kansas: Journal of Paleontology, v. 55, no. 1, p. 65-71.

Mitchell, C. T., 1899, Notes on the Mollusca of Canandaigua Lake region, N. Y.: The Nautilus, v. 13, no. 8, p. 87-89.

Moretzsohn, Fabio, and McShane, Myra, 2003, Part 1 Survey of the land snails and slugs of the Hakalau Forest National Wildlife Refuge, Island of Hawaii, in Howarth, F. G., Preston, David, Moretzsohn, Fabio, and McShane, Myra, eds., Final report invertebrate survey of Hakalau Forest National Wildlife Refuge, Hawaii: United States Department of the Interior, U. S. Geological Survey, p. 1-29. Available from: http://hbs.bishopmuseum.org/pdf/hakalau-final.pdf (accessed May 4, 2009).

Morrison, J. P. E., 1932, A report on the Mollusca of the northeastern Wisconsin lake district: Transactions of the Wisconsin Academy of Sciences, Arts, and Letters, v. 27, p. 359-396.

Morrison, R. B., 1991, Introduction, in Morrision, R. B., ed., Quaternary Nonglacial Geology:

Conterminous U. S.: Geological Society of America, The Geology of North America, v. K-2, p. 1-12.

Muchmore, W. B., 1959, Land snails of E. N. Huyck Preserve, New York: The Nautilus, v. 72, no. 3, p. 85-89.

National Oceanic and Atmospheric Administration, 1978a, Climates of the states, national oceanic and atmospheric administration narrative summaries, tables, and maps for each state with current tables of normals, 1941-1970, means and extremes to 1975, overview of state climatological programs (v. 1): Detroit, MI, Gale Research Company, p. 1-606.

$\ldots-1978 \mathrm{~b}$, Climates of the states, national oceanic and atmospheric administration narrative summaries, tables, and maps for each state with current tables of normals, 1941-1970, means and extremes to 1975, overview of state climatological programs (v. 2): Detroit, MI, Gale Research Company, p. 607-1185.

-----last updated 2009, Annual climatological summary (2008): 145171/99999, Meade, Kansas [internet]: US Department of Commerce, National Oceanic and Atmospheric Administration, Silver Spring, MD. Available from: http://cdo.ncdc.noaa.gov/ancsum/ACS (accessed February 25, 2010).

Neck, R. W., 1977, New county records of land snails of Texas: Sterkiana, no. 65-66, p. 5-6.

-..-1990, Ecological analysis of the living molluscs of the Texas panhandle: American Malacological Bulletin, v. 8, no. 1, p. 9-18.

Nekola, J. C., 2002, Distribution and ecology of terrestrial gastropods in northwestern Minnesota: Final Report, 2001-2002 Natural Heritage and Nongame Research Program, Division of Fish and Wildlife, Minnesota Department of Natural Resources, 178 p + appendix. Available from: http://files.dnr.state.mn.us/eco/nongame/projects/consgrant_reports/2002/2002_nekola.pdf (accessed May 4, 2009). 
-----2004, Terrestrial gastropod fauna of northeastern Wisconsin and the southern Upper Peninsula of Michigan: American Malacological Bulletin, v. 18, no. 1/2, p. 21-44.

-----2008, Land snail ecology and biogeography of eastern Maine: Final Report submitted to the Maine Department of Inland Fisheries and Wildlife, Aroostook Hills and Lowlands Inventory. Available from: http://sev.Iternet.edu/ jnekola/nekola\%20pdf/mednr-2007.pdf (accessed May 4, 2009).

Nekola, J. C., Barthel, Matthew, Massart, Peter, and North, Eric, 1999, Terrestrial gastropod inventory of igneous outcrops in northeastern Minnesota, final report: 1998 Natural Heritage and Nongame Research Program, Division of Fish and Wildlife, Minnesota Department of Natural Resources, St. Paul, MN, 69 p. Available from: http://files.dnr.state.mn.us/eco/nongame/projects/consgrant_reports/1999/1999_nekola.pdf (accessed May 4, 2009).

Nekola, J. C., and Coles, B. F., 2010, Pupillid land snails of eastern North America: American Malacological Bulletin, v. 28, no. 1/2, p. 29-57.

Nekola, J. C., and Massart, P. A., 2001, Distribution and ecology of Vertigo nylanderi Sterki, 1909 in the western Great Lakes region: American Malacological Bulletin, v. 16, no. 1/2, p. 53-60.

Nekola, J. C., and Smith, T. M., 1999, Terrestrial gastropod richness patterns in Wisconsin carbonate cliff communities: Malacologia, v. 41, no. 1, p. 253-269.

Nichelson, E. H., 1953, A preliminary survey of the land mollusks of Alachua County, Florida: The Nautilus, v. 67, no. 2, p. 48-53.

Norden, A. W., 2008, The terrestrial gastropods (Mollusca: Gastropoda) of Plummers Island, Maryland: Bulletin of the Biological Society of Washington, no. 15, p. 31-40.

Nylander, O. O., 1900, A list of shells from northeastern Maine: The Nautilus, v. 13, no.9, p. 102-106.

----1909, Fossil and living shells found in Little Mud Lake, Westmanland, Aroostook County, Maine: The Nautilus, v. 22, no. 10, p. 105-106.

----1914, Fresh water shells in Moose River, Somerset County, Maine: The Nautilus, v. 28, no. 8, p. 89.

----1936, Land and fresh water shells of Aroostook County, Maine: Caribou, ME, Privately Published, 23 p.

Odhner, N. H., 1939, Sphaeriids from the Aleutian Islands: The Nautilus, v. 52, no. 3, p. 79-84 + plate.

Ogg, J. G., Ogg, Gabi, and Gradstein, F. M., 2008, The concise geologic time scale: New York, NY, Cambridge University, $177 \mathrm{p}$.

Oliver, G. V., and Bosworth, W. R., III, 1999, Rare, imperiled, and recently extinct or extirpated mollusks of Utah, a literature review: Utah Division of Wildlife Resources Publication 99-29, 231 p + appendix. Available from: http://dwrcdc.nr.utah.gov/ucdc/ViewReports/mollrpt.pdf (accessed May 15, 2009).

Örstan, Aydin, 1999, Land snails of Black Hill Regional Park, Montgomery County, Maryland: The Maryland Naturalist, v. 43 , no. 3-4, p. 20-24.

Ostlie, W. R., [1990?], Completion of the algific slope/maderate cliff landsnail survey in Minnesota: The Nature Conservancy, Midwest Regional Office, Minneapolis, MN, 11 p. + figures and appendices. Available from: http://files.dnr.state.mn.us/eco/nongame/projects/consgrant reports/1990/1990_ostlie.pdf (accessed May 4, 2009). 
Over, W. H., 1915, Mollusca of South Dakota: The Nautilus, v. 29, no. 8, p. 90-95.

----1928, Additional records of South Dakota Mollusca: The Nautilus, v. 41, no. 3, p. 92-93.

----1942, Mollusca of South Dakota: Vermillion, SD, University of South Dakota, 11 p.

Pace, G. L., Szuch, E. J., and Dapson, R. W., 1979, Depth distribution of three gastropods in New Mission Bay, Lake Michigan: The Nautilus, v. 93, no. 1, p. 31-36.

Pearce, T. A., 2008, Land snails of limestone communities and update of land snail distributions in Pennsylvania: Final Report for Grant Agreement WRCP-04016, 51 p. Available from: http://www.carnegiemnh.org/mollusks/WRCP\%20report.pdf (accessed May 4, 2009).

Pearce, T. A., and Evans, Ryan, 2008, Freshwater Mollusca of Plummers Island, Maryland: Bulletin of the Biological Society of Washington, no. 15, p. 20-30.

Pearce, T. A., Fields, M. C., and Kurita, Kayoko, 2007, Discriminating shells of Gastrocopta pentodon (Say, 1822) and G. tappaniana (C. B. Adams, 1842) (Gastropoda: Pulmonata) with an example from the Delmarva Peninsula, eastern USA: The Nautilus, v. 121, no. 2, p. 66-75.

Pielou, E. C. 1979. Biogeography. Wiley Press, New York.

Pilsbry, H. A., 1886, Notes on some New Orleans fresh-water shells: The Conchologists' Exchange, v. 1, no. 5 , p. 20-21.

---1900, Notes on certain Mollusca of southwestern Arkansas: Proceedings of the Academy of Natural Sciences of Philadelphia, v. 52, p. 449-459.

----1903, Shells of Douglas Co., central Washington: The Nautilus, v. 17, no. 7, p. 84.

----1906, Shells of Grant, Valencia Co., New Mexico: The Nautilus, v. 19, no. 11, p. 130.

----1934, Review of the Planorbidae of Florida, with notes on other members of the family: Proceedings of the Academy of Natural Sciences of Philadelphia, v. 86, p. 29-66 + plates.

Pilsbry, H. A., and Ferriss, J. H., 1906a, Mollusca of the Ozarkian fauna: Proceedings of the Academy of Natural Sciences of Philadelphia, v. 58, p. 529-567 + plates.

---1906b, Mollusca of the southwestern states. ii: Proceedings of the Academy of Natural Sciences of Philadelphia, v. 58, p. 123-174.

----1909, Mollusca of the southwestern states, iii: the Huachuca Mountains, Arizona: Proceedings of the Academy of Natural Sciences of Philadelphia, v. 61, p. 495-516.

----1911, Mollusca of the southwestern states, v: the Grand Canyon and northern Arizona, Proceedings of the Academy of Natural Sciences of Philadelphia, v. 63, p. 174-199.

----1915, Mollusca of the southwestern states, vii: the Dragoon, Mule, Santa Rita, Baboquivari, and Tucson Ranges, Arizona: Proceedings of the Academy of Natural Sciences of Philadelphia, v. 67, no. 2, p. 363-418 + plate.

----1917, Mollusca of the southwestern states, viii: the Black Range, New Mexico: Proceedings of the Academy of Natural Sciences of Philadelphia, v. 69, p. 83-107.

-----1918, Mollusca of the southwestern states-ix, the Santa Catalina, Rincon, Tortillita and Galiuro 
Mountains. $x$, the mountains of the Gila Headwaters: Proceedings of the Academy of Natural Sciences of Philadelphia, v. 70, p. 282-333 + plates.

Pinney, M. E., 1934, Terrestrial and fresh water gastropods of the Allegany State Park in New York State: The Nautilus, v. 48 , no. 2 , p. 55-60.

Pleas, E., 1893, Shells of Henry Co., Indiana: The Nautilus, v. 7, no. 6, p. 68-70.

Ports, M. A., 1996, Habitat affinities and distributions of land gastropods from the Ruby Mountains and East Humboldt Range of northeastern Nevada: The Veliger, v. 39, no. 4, p. 335-341.

Price, S. F., 1900, Mollusca of southern Kentucky: The Nautilus, v. 14, no. 7, p. 75-79.

Pyron, Mark, Beugly, Jayson, Martin, Erika, and Spielman, Matthew, 2008, Conservation of the freshwater gastropods of Indiana: historic and current distributions: American Malacological Bulletin, v. 26, no. 1/2, p. $137-151$.

Rand Mc.Nally, 2009a, Commercial atlas \& marketing guide (140 th ed., v. 1): Chicago, IL, Rand Mc.Nally, $271 \mathrm{p}$.

----2009 b, Commercial atlas \& marketing guide ( $140^{\text {th }}$ ed., v. 2): Chicago, IL, Rand Mc.Nally, 322 p.

----2009c, The road atlas: Chicago, IL, Rand Mc.Nally, 140 p.

Randolph, P. B., 1896, Shells of Seattle, King Co., Washington: The Nautilus, v. 9, no. 9, p. 101-102.

Reeder, R. L., and Miles, C. D., 1976, Land snails from northern Missouri: Sterkiana, no. 61, p. 15-18.

Rees, W. J., 1965, The aerial dispersal of Mollusca: Proceedings of the Malacological Society of London, v. 36, p. $269-282$.

Rehder, H. A., 1949, Some land and freshwater mollusks from the coastal region of Virginia and North and South Carolina: The Nautilus, v. 62, no. 4, p. 121-126.

Reigle, N. J., 1963, Northern records of Gastrocopta procera: The Nautilus, v. 77, no. 1, p. 16-18.

Rhoads, S. N., 1899a, Annotated list of land and fresh-water shells recently collected in the vicinity of Miami, Florida: The Nautilus, v. 13, no. 4, p. 43-48.

----1899b, On a recent collection of Pennsylvanian mollusks from the Ohio River system below Pittsburg: The Nautilus, v. 12, no. 12, p. 133-138.

-..-1904, A glimpse at the shell fauna of Delaware: The Nautilus, v. 18, no. 6, p. 63-67.

Richards, H. G., 1934, A list of the mollusks of the District of Columbia and vicinity: American Midland Naturalist, v. 15 , p. $85-88$.

Riddle, W. A., 1990, High temperature tolerance in three species of land snails: Journal of Thermal Biology, v. 15, no. 2, p. 119-124.

Roscoe, E. J., 1954, Terrestrial gastropods from the Black Hills, Lawrence County, South Dakota, with a summary of published records from the state: Proceedings of the Utah Academy of Science, Arts, and Letters, v. 31, p. 67-72.

----1955, Additional South Dakota terrestrial gastropod records: American Midland Naturalist, v. 54, no. 
2, p. 511-512.

Rosewater, Joseph, 1959, Mollusks of the Salt River, Kentucky: The Nautilus, v. 73, no. 2, p. 57-63.

Ross, M. J., and Ultsch, G. R., 1980, Temperature and substrate influences on habitat selection in two pleurocerid snails (Goniobasis): The American Midland Naturalist, v. 103, no. 2, p. 209-217.

Roth, Barry, and Lindberg, D. R., 1981, Terrestrial mollusks of Attu, Aleutian Islands, Alaska: Arctic, v. 34 , no. 1, p. 43-47.

Roth, Barry, and Sadeghian, P. S., 2006, Checklist of the land snails and slugs of California ( $2^{\text {nd }}$ ed.): Santa Barbara Museum of Natural History Contributions in Science 3, $82 \mathrm{p}$.

Sampson, F. A., 1912, Shells of southeast Missouri: The Nautilus, v. 26, no. 8, p. 90-95.

Sargent, H. E., 1896, Annotated list of the Mollusca found in the vicinity of Clearwater, Wright Co., Minnesota: The Nautilus, v. 9, no. 11, p. 125-128.

SAS Institute Inc., 2003, JMP: v. 5.0.1.2, Cary, NC.

Scott, G. H., 1963, Uniformitarianism, the uniformity of nature, and paleoecology: New Zealand Journal of Geology and Geophysics, v. 6, p. 510-527.

Severns, P. M., 2005, Response of a terrestrial mollusc community to an autumn prescribed burn in a rare wetland prairie of western Oregon, USA: Journal of Molluscan Studies, v. 71, p. 181-187.

Singley, J. A., 1893, Contributions to the natural history of Texas, part 1, Texas Mollusca: Geological Survey of Texas, $4^{\text {th }}$ Annual Report, part 10, p. 297-343.

Smith, A. G., 1943, Mollusks of the Clearwater Mountains, Idaho: Proceedings of the California Academy of Sciences, Fourth Series, v. 23, no. 36, p. 537-554 + plates.

Smith, D. G., 1994, On some Connecticut, U. S. A., snails reported by J. H. Linsley: Malacological Review, v. 27, p. 1-4.

Smith, Maxwell, 1906, Shells of Richfield Springs, New York and vicinity: The Nautilus, v. 20, no. 8, p. 89-91.

Smith, Sanderson, and Prime, Temple, 1870, Report on the Mollusca of Long Island, N. Y., and of its dependencies: Annals of the Lyceum of Natural History, v. 9, p. 377-407.

Spamer, E. E., and Bogan, A. E., 1993, New records of Mollusca for Grand Canyon National Park and Arizona: The Southwestern Naturalist, v. 38, no. 3, p. 293-298.

Stearns, R. E. C., 1900, List of shells collected by Vernon Bailey in Heron and Eagle Lakes, Minnesota, with notes: Proceedings of the United States National Museum, v. 22, no. 1190, p. 135-138.

Sterki, V., 1900, List of the land and fresh water Mollusca of Tuscarawas County, Ohio: Eighth annual report of the Ohio State Academy of Science, p. 30-42.

----1916, Mollusks of Geneva, Ohio: The Nautilus, v. 29, no. 11, p. 121-124.

Stewart, T. W., 2006, The freshwater gastropods of lowa (1821-1998): species composition, geographic distributions, and conservation concerns: American Malacological Bulletin, v. 21, no. 1/2, p. 59-75. 
Stewart, T. W., and Dillon, R. T., Jr., 2004, Species composition and geographic distribution of Virginia's freshwater gastropod fauna: a review using historical records: American Malacological Bulletin, v. 19, no. $1 / 2$, p. $79-91$.

Strecker, J. K., Jr., 1908, The Mollusca of McLennan County, Texas: The Nautilus, v. 22, no. 7, p. 63-67.

----1935, Land and fresh-water snails of Texas: Transactions of the Texas Academy of Science, v. 17, p. $1-50$.

Taft, Celeste, 1961, The shell-bearing land snails of Ohio: Bulletin of the Ohio Biological Survey New Series, v. 1, no. 3, p. 1-108.

Taylor, D. W., 1954, A new Pleistocene fauna and new species of fossil snails from the High Plains: Occasional Papers of the Museum of Zoology, University of Michigan, no. 557, p. 1-16.

-----1960, Late Cenozoic molluscan faunas from the High Plains, description of mollusks from nine Pliocene and Pleistocene faunas of the High Plains region and interpretation of their stratigraphic and ecologic significance: Geological Survey Professional Paper 337, 94 p.

----1981, Freshwater mollusks of California: a distributional checklist: California Fish and Game, v. 67, no. 3 , p. 140-163.

-...-1987, Fresh-water molluscs from New Mexico and vicinity: New Mexico Bureau of Mines \& Mineral Resources Bulletin 116, $50 \mathrm{p}$.

----1988, New species of Physa (Gastropoda: Hygrophila) from the western United States: Malacological Review, v. 21, p. 43-79.

Taylor, R. W., Counts, C. L., III, and Stryker, S. L., 1977, The land snails of Carter Caves State Park, Carter County, Kentucky: Sterkiana, no. 65-66, p. 37-38.

Teskey, M. C., 1954, The mollusks of Brown County, Wisconsin: The Nautilus, v. 68, no. 1, p. 24-28.

---1955, The mollusks of Warm Springs, Georgia: The Nautilus, v. 69, no. 2, p. 69-71.

Theler, J. L., 1997, The modern terrestrial gastropod (land snail) fauna of western Wisconsin's hill prairies: The Nautilus, v. 110, no. 4, p. 111-121.

Theler, J. L., Wyckoff, D. G., and Carter, B. J., 2004, The southern plains gastropod survey: the distribution of land snail populations in an American grassland environment: American Malacological Bulletin, v. 18, no. $1 / 2$, p. $1-20$.

The Nautilus, 1894, Land and fresh-water shells of Allegheny County, PA. collected by S. H. Stupakoff of Pittsburgh, PA., from Jan., 1890 to Dec., 1893: The Nautilus, v. 7, no. 12, p. 135-136.

-----1898, Shells of Redding, Shasta Co., California: The Nautilus, v. 12, no. 5, p. 59-60.

Thompson, F. G., 1968, The aquatic snails of the family Hydrobiidae of peninsular Florida: Gainesville, FL, University of Florida Press, $268 \mathrm{p}$.

Tiemann, J. S., and Cummings, K. S., 2009, Additional distribution records for freshwater snails in Kansas, with comments on a reversed Campeloma crassulum: Transactions of the Kansas Academy of Science, $\mathbf{v}$. 112 , no. $3 / 4$, p. $222-224$.

Tryon, G. W., Jr., 1865, Catalogue of Mollusca, collected by prof. D. S. Sheldon, at Davenport, lowa: 
American Journal of Conchology, v. 1, no. 1, p.68-70.

---1868, Notes on Mollusca collected by Dr. F. V. Hayden, in Nebraska: American Journal of Conchology, v. 4, no. 3, p. 150-151.

Tucker, J. K., Funk, R. S., and Moll, Don, 1977, Distributional records of Polygyrid snails in Illinois with an addition to the state fauna: Transactions of the Illinois State Academy of Science, v. 70, no. 1, p. 86-90.

Tuthill, S. J., 1963, Preliminary report on the molluscan fauna of the Martin River Glacier and associated area: The Veliger, v. 6 , no. 2, p. 84-90.

Tuthill, S. J., and Johnson, R. L., 1969, Nonmarine mollusks of the Katalla region, Alaska: The Nautilus, v. 83 , no. 2 , p. $44-52$.

United States Fish and Wildlife Service, 1982a, Ecoregions and land-surface forms of Alaska and Hawaii: United States Fish and Wildlife Service, Department of the Interior, scale 1:5,000,000.

----1982b, Ecoregions and land-surface forms of the United States: United States Fish and Wildlife Service, Department of the Interior, scale 1:5,000,000.

United States Geological Survey, first accessed 2006, The national map, legacy viewer [internet]: Reston, VA, United States Geological Survey, Department of the Interior. Available from:

http://nmviewogc.cr.usgs.gov/viewer.htm (accessed September 2006-November 2009).

Vanatta, E. G., 1920, Land shells from Beaver County, Pennsylvania: The Nautilus, v. 34, no. 1, p. 28.

Vaughan, T. W., 1892, Mollusks of Dorcheat Bayou and Lake Bisteneau, Louisiana: The Nautilus, v. 5, no. 10, p. 109-111.

----1893, Notes on a collection of mollusks from north western Louisiana, and Harrison County, Texas: The American Naturalist, v. 27, no. 323, p. 944-961.

Waggoner, Janet, Clark, S. A., Perez, K. E., and Lydeard, Charles, 2006, A survey of terrestrial gastropods of the Sipsey Wilderness (Bankhead National Forest), Alabama: Southeastern Naturalist, v. 5, no. 1, p. 5768 .

Wallen, I. E., 1951, Additions to "a check list of the land snails of Oklahoma": Proceedings of the Oklahoma Academy of Science for 1951, v. 32, p. 27-30.

Wallen, I. E., and Dunlap, Paul, 1953, Further additions to the snail fauna of Oklahoma: Proceedings of the Oklahoma Academy of Science, v. 34, p. 76-80.

Walker, Bryant, 1899, The terrestrial Mollusca of Michigan: Detroit, MI, Privately Published, $27 \mathrm{p}$.

---1906, A list of shells from Nebraska: The Nautilus, v. 20, no. 7, p. 81-83.

----1915, Results of the Mershon expedition to the Charity Islands, Lake Huron: Occasional Papers of the Museum of Zoology, no. 7, p. 1-7.

----1928, The terrestrial shell-bearing Mollusca of Alabama: University of Michigan Museum of Zoology Miscellaneous Publication 18, $180 \mathrm{p}$.

Walker, R. D., and Coolidge, W. H., Jr., 1908, Mollusca of Keene, New Hampshire: The Nautilus, v. 22, no. 3 , p. 32 . 
Walther, A. C., Lee, Taehwan, Burch, J. B., and Foighil, D. Ó., 2006, E pluribus unum: a phylogenetic and phylogeographic reassessment of Laevapex (Pulmonata: Ancylidae), a North American genus of freshwater limpets: Molecular Phylogenetics and Evolution, v. 40, p. 501-516.

Watters, G. T., Menker, Trisha, and O'Dee, S. H., 2005, A comparison of terrestrial snail faunas between strip-mined land and relatively undisturbed land in Ohio, USA - an evaluation of recovery potential and changing faunal assemblages: Biological Conservation, v. 126, p. 166-174.

Wells, P. V., and Stewart, J. D., 1987, Cordilleran-boreal taiga and fauna on the central Great Plains of North America, 14,000-18,000 years ago: The American Midland Naturalist, v. 118, no. 1, p. 94-106.

Wethington, A. R., Wise, John, and Dillon, R. T., Jr., 2009, Genetic and morphological characterization of the Physidae of South Carolina (Gastropoda: Pulmonata: Basommatophora), with description of a new species: The Nautilus, v. 123, no. 4, p. 282-292.

Wheat, S. C., 1907a, List of Long Island shells: Bulletin of the Brooklyn Conchological Club, v. 1, no. 1, p. $7-10$.

$----1907 \mathrm{~b}$, Shells in city gardens and ponds: Bulletin of the Brooklyn Conchological Club, v. 1, no. 1, p. 6.

Wheeler, H. E., 1912, The Mollusca of Monte Sano, Alabama: The Nautilus, v. 25, no. 11, p. 121-127.

----1918, The Mollusca of Clark County, Arkansas: The Nautilus, v. 31, no. 4, p. 109-125.

Wilson, Druid, 1960, Land snails from central south Florida: The Nautilus, v. 73, no. 4, p. 137-139.

Winkley, H. W., 1909, Pisidium in Massachusetts: The Nautilus, v. 22, no. 11, p. 113-114.

Winslow, M. L., 1917, An annotated list of shells from northern Michigan: Occasional Papers of the Museum of Zoology, no. 42, p. 1-16.

----1921a, Mollusca of North Dakota: Occasional Papers of the Museum of Zoology, no. 98, p. 1-18.

$-\ldots-1921 \mathrm{~b}$, Shells from Alcona, Oscoda and Crawford Counties, Michigan: Occasional Papers of the Museum of Zoology, no. 102, p. 1-5.

Wolf, John, 1870, Catalogue of the shell-bearing Mollusca of Fulton County, llinois: American Journal of Conchology, v. 6, no. 1, p. 27-29.

Wood, D. H., 1982, The aquatic snails (Gastropoda) of the Savannah River Plant Aiken, South Carolina: Savannah River Plant National Environmental Research Park Program, Department of Energy, 46 p.

Wood, W. M., and Raymond, W. T., 1891, Mollusks of San Francisco County: The Nautilus, v. 5, no. 5, p. 54-58.

Woolstenhulme, J. P., 1942, New records of Mollusca: Bulletin of the University of Utah, v. 32, no. 11, p. 4-14.

Wu, S.-K., 1989, Colorado freshwater mollusks: Natural History Inventory of Colorado 11, $117 \mathrm{p}$.

Wu, S.-K., Oesch, R. D., and Gordon, M. E., 1997, Missouri aquatic snails: Missouri Department of Conservation Natural History Series 5, $97 \mathrm{p}$.

Wurtz, C. B., 1940, New state and county records of land-snails in Pennsylvania: The Nautilus, v. 53, no. 3, p. 84-88. 
----1948, Some land snails from West Virginia with description of a new species: The Nautilus, v. 61, no. 3, p. 80-89.

-----1949, Some snail records from southeastern Ohio: The Nautilus, v. 62, no. 3, p. 91-93.

Wurzinger, K-H., 1975, The land snails of New York state preliminary report: Sterkiana, no. 57, p. 33-39. 


\section{APPENDICES}

\section{Appendix 1}

Vegetation Codes. Alphanumeric codes and vegetation titles of the ecoregion Provinces and Sections used in the Climate Database. Modified from United States Fish and Wildlife Service (1982a, b).

\begin{tabular}{|c|c|}
\hline PROVINCE AND SECTION CODES & VEGETATION \\
\hline 1210 & Arctic Tundra Province \\
\hline 1220 & Bering Tundra Province \\
\hline 1320 & Yukon Forest Province \\
\hline 2111 & Spruce-fir Forest Section \\
\hline 2112 & Northern Hardwoods-Fir Forest Section \\
\hline 2113 & Northern Hardwoods Forest Section \\
\hline 2114 & Northern Hardwoods-Spruce Forest Section \\
\hline 2211 & Mixed Mesophytic Forest Section \\
\hline 2212 & Beech-Maple Forest Section \\
\hline 2213 & Maple-Basswood Forest and Oak Savanna Section \\
\hline 2214 & Appalachian Oak Forest Section \\
\hline 2215 & Oak-Hickory Forest Section \\
\hline 2311 & Beech-Sweetgum-Magnolia-Pine-Oak Forest Section \\
\hline 2312 & Southern Floodplain Forest Section \\
\hline 2320 & Southern Mixed Forest Province \\
\hline 2410 & Willamette-Puget Forest Province \\
\hline 2511 & Oak-Hickory-Bluestem Parkland Section \\
\hline 2512 & Oak and Bluestem Parkland Section \\
\hline 2521 & Mesquite-Buffalo Grass Section \\
\hline 2522 & Juniper-Oak-Mesquite Section \\
\hline 2523 & Mesquite-Acacia Section \\
\hline 2531 & Bluestem Prairie Section \\
\hline 2532 & Wheatgrass-Bluestem-Needlegrass Section \\
\hline 2533 & Bluestem-Grama Prairie Section \\
\hline 2610 & California Grassland Province \\
\hline 3111 & Grama-Needlegrass-Wheatgrass Section \\
\hline 3112 & Wheatgrass-Needlegrass Section \\
\hline 3113 & Grama-Buffalo Grass Section \\
\hline 3120 & Palouse Grassland Province \\
\hline 3131 & Sagebrush-Wheatgrass Section \\
\hline
\end{tabular}




\section{Appendix 1 Continued}

\begin{tabular}{|c|c|}
\hline PROVINCE AND SECTION CODES & VEGETATION \\
\hline 3132 & Lahontan Saltbush-Greasewood Section \\
\hline 3133 & Great Basin Sagebrush Section \\
\hline 3134 & Bonneville Saltbush-Greasewood Section \\
\hline 3140 & Mexican Highlands Shrub Steppe Province \\
\hline 3211 & Grama-Tobosa Section \\
\hline 3212 & Tarbush-Creosote Bush Section \\
\hline 3221 & Creosote Bush Section \\
\hline 3222 & Creosote Bush-Bar Sage Section \\
\hline 4110 & Everglades Province \\
\hline A3141 & Wheatgrass-Needlegrass-Sagebrush Section \\
\hline A3142 & Sagebrush-Wheatgrass Section \\
\hline M1310 & Alaska Range Province \\
\hline M2111 & Douglas-fir Forest Section \\
\hline $\mathrm{M} 2112$ & Cedar-Hemlock-Douglas-fir Forest Section \\
\hline $\mathrm{M} 2410$ & Pacific Forest Province \\
\hline M2411 & Sitka Spruce-Cedar-Hemlock Forest Section \\
\hline M2412 & Redwood Forest Section \\
\hline M2413 & Cedar-Hemlock-Douglas-fir Forest Section \\
\hline $\mathrm{M} 2414$ & California Mixed Evergreen Forest Section \\
\hline M2415 & Silver Fir-Douglas-fir Forest Section \\
\hline M2610 & Sierran Forest Province \\
\hline M2620 & California Chaparral Province \\
\hline M3111 & Grand Fir-Douglas-fir Forest Section \\
\hline M3112 & Douglas-fir Forest Section \\
\hline M3113 & Ponderosa Pine-Douglas-fir Forest Section \\
\hline M3120 & Upper Gila Mountains Forest Province \\
\hline $\mathrm{M} 4210$ & Hawaiian Islands Province \\
\hline P3131 & $\begin{array}{c}\text { Juniper-Pinyon Woodland and Sagebrush-Saltbush } \\
\text { Mosaic Section }\end{array}$ \\
\hline P3132 & $\begin{array}{l}\text { Grama-Galleta Steppe and Juniper-Pinyon } \\
\text { Woodland Section }\end{array}$ \\
\hline
\end{tabular}




\section{Appendix 2}

Appendix 2a. Molluscan Biogeography Database Citations. A list of all the publications which contributed to the Molluscan Biogeography Database. The full citations are in the References section.

Adams, C. B. (1841), Adams, W. F. and Brady (1995), Ahlstrom (1930), Alexander (1947, 1952), Anderson (2005), Archer (1936, 1939), Aughey (1877), Baker, F. C. (1899a, b, 1900a, b, 1904, 1905, 1906a, b, 1909, 1910, 1911a, b, $1913,1914,1915,1916,1918,1919,1920,1922,1924,1927,1928,1929 a, b, 1935 a, b, 1942)$, Baker, H. B. (1922, 1930), Basch et al. (1961), Beasley and Fullington (1978), Beetle (1954, 1957, 1960, 1967, 1973, 1989), Berry (1909, 1910, 1913, 1916a, b, 1937, 1948), Blakeslee ([n. d.]), Blatchley ([n. d.]), Bogan et al. (1982), Brady and Pearce (2007), Branson (1956, 1959, 1960a, b, 1961a, b, 1962a, b, 1963a, b, 1966, 1969, [1970?], 1970, 1971, 1973, 1977, 1980a, b, 1981), Branson and Batch (1968, 1969, 1971, 1981a, b, 1982, 1983, 1988), Branson and Branson (1984 1991), Branson and Wallen (1955), Branson et al. (1987), Bretet and Carswell (1952), Briscoe (1963), Brooks (1931), Brooks and Kutchka (1937, 1938), Burch, J. B. (1952, 1954, 1955), Burch, P. R. (2002), Burky et al. (2000), Bushey (1950a, b), Caffrey (1911), Cahn and Kemp (1929), Call (1885, 1886, 1887), Carpenter (1887a, b, 1902), Chadwick (1906), Chamberlin and Berry (1930), Cheatum and Burt (1931), Cheatum and Fullington (1973), Clapp (1895), Clark (1962), Clench (1926), Clench and Boss (1967), Clench and Russell (1940), Clench and Turner (1956), Counts (1982), Cowie (1997), Cowie et al. (2008), Currier (1865), Cvancara (1983), Dall (1885, 1917), Daniels (1909, 1920), Dawley (1955, 1965), Dexter (1950, 1953, 1956), Dillon and Herman (2009), Dirrigl and Bogan (1995), Dourson (2007), Dourson and Beverly (2008), Dourson and Feeman (2006), Dundee and Watt (1961), Einsohn (1981), Elrod (1902a, b), Eyerdam (1933, 1939, 1940), Ferriss (1906), Flowers and Miller (1993), Franzen and Leonard, A. B. (1942), Freed (1957), Frest (1987), Frest and Johannes (1993, 1997a, b, 2002), Fullington and Pratt (1974), Getz (1962), Goodrich (1931, 1939, 1944a, b), Goodrich and van der Schalie (1944), Gordon (1985), Gordon et al. (1993), Greger (1915), Grimm (1959a, b, 1961, 1971, 1975), Haas (1954), Hanna (1909, 1925, 1956), Harman (1998), Harman and Berg (1970), Harman and Forney (1970), Harper and Wetherby (1876), Heard (1963), Heilman (1951, 1952), Heilman and MacMillan (1958), Henderson, J. (1907, 1912, 1918, 1927), Henderson, J. B. (1907a, b), Henderson, J., and Daniels (1917), Hendricks et al. (2006), Hinkley (1904a, b, 1906a, b, 1915, 1919), Hoff (1962), Hotopp (2002), Hotopp and Pearce (2007), Hubbard and Smith (1865), Hubricht (1950, 1951, 1952, 1953, 1960, 1963a, b, 1964a, b, 1965, 1967 , 1968a, b, 1970, 1971 a, b, c, 1972a, b, 1973, 1977, 1983, 1985), Ideker (1979), Ingersoll (1877), Jacobson and Emerson (1961), Jass (1980, 1986, 2004), Jass and Glenn (2002), Johnson (1910), Jokinen (1983, 1992, 2005), Jones (1941), Keyes (1888), Lapham (1860), Laursen et al. (1989), Laursen et al. (1992), Lee (2006, 2008), Lehnert (1885), Leonard, A. B. (1959), Leonard, A. B., and Goble (1952), Leonard, A. B., and Leonard, A. E. (1946), Leonard, A. E. (1943), Lermond (1914), Levi and Levi (1950), Lewis (1860, 1876), Liechti and Mackie (1977), Lowe (1917), Lutz (1949, 1950), Lysne and Clark (2009), Lysne and Pierce (2009), MacMillan (1949), Marsh (1887, 1888a, b, c), Martin (1999, 2000), McDonnell et al. (2009), Meretsky et al. (2002), Metcalf (1984a, b), Metcalf et al. (1997), Miles (1958), Miller and Hibbard (1972), Mitchell (1899), Moretzsohn and McShane (2003), Morrison (1932), Muchmore (1959), Neck (1977, 1990), Nekola (2002, 2004, 2008), Nekola and Coles (2010), Nekola and Massart (2001), Nekola and Smith (1999), Nekola et al. (1999), Nichelson (1953), Norden (2008), Nylander (1900, 1909, 1914, 1936), Odhner (1939), Oliver and Bosworth (1999), Örstan (1999), Ostlie ([1990?]), Over (1915, 1928, 1942), Pace et al. (1979), Pearce (2008), Pearce and Evans (2008), Pearce et al. (2007), Pilsbry (1886, 1900, 1903, 1906, 1934), Pilsbry and Ferriss (1906a, b, 1909, 1911, 1915, 1917, 1918), Pinney (1934), Pleas (1893), Ports (1996), Price (1900), Pyron et al. (2008), Randolph (1896), Reeder and Miles (1976), Rehder (1949), Reigle (1963), Rhoads (1899a, b, 1904), Richards (1934), Roscoe (1954, 1955), Rosewater (1959), Roth and Lindberg (1981), Roth and Sadeghian (2006), Sampson (1912), Sargent (1896), Severns (2005), Singley (1893), Smith, A. G. (1943), Smith, D. G. (1994), Smith, M. (1906), Smith, S. and Prime (1870), Spamer and Bogan (1993), Stearns (1900), Sterki (1900, 1916), Stewart (2006), Stewart and Dillon (2004), Strecker (1908, 1935), Taft (1961), Taylor (1981, 1987, 1988), Taylor et al. (1977), Teskey (1954, 1955), Theler (1997), Theler et al. (2004), The Nautilus (1894, 1898), Thompson (1968), Tiemann and Cummings (2009), Tryon (1865, 1868), Tucker et al. (1977), Tuthill (1963), Tuthill and Johnson (1969), Vanatta (1920), Vaughan (1892, 1893), Waggoner et al. (2006), Walker (1899, 1906, 1915, 1928), Walker and Coolidge (1908), Wallen (1951), Wallen and Dunlap (1953), Walther et al. (2006), Watters et al. (2005), Wethington et al. (2009), Wheat (1907a, b), Wheeler (1912, 1918), Wilson (1960), Winkley (1909), Winslow (1917, 1921a, b), Wolf (1870), Wood (1982), Wood and Raymond (1891), Woolstenhulme (1942), Wu (1989), Wu et al. (1997), Wurtz (1940, 1948, 1949), Wurzinger (1975). 
Appendix 2 Continued

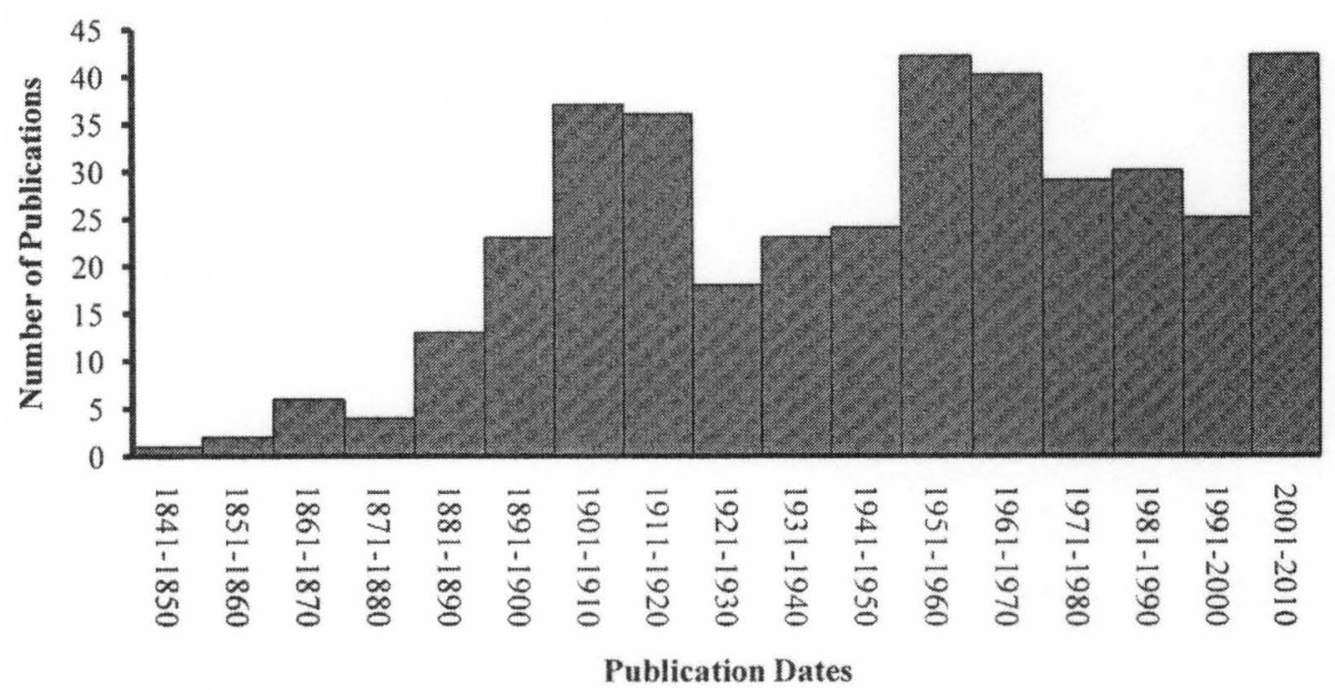

Appendix 2b. Biogeographic Publications by Decade. Graph depicting the frequency of publishing per decade for the publications listed above. Additional summary data: total number of publications used in the Molluscan Biogeography Database $=395$ dated publications and two undated publications, range of publication dates $=1841 ; 2010$, mean publication year $=1948$, median publication year $=1953$, modal publication year $=1906$. 


\section{Appendix 3}

Molluscan Taxonomy. A list of all the taxa examined in this study. Taxonomic names are from the Integrated Taxonomic Information System (2006), except those which are marked with a caret symbol $\left({ }^{\wedge}\right)$. Taxa with this mark are believed to be extinct and are described in Baker (1938), Leonard (1946), and Taylor (1960).

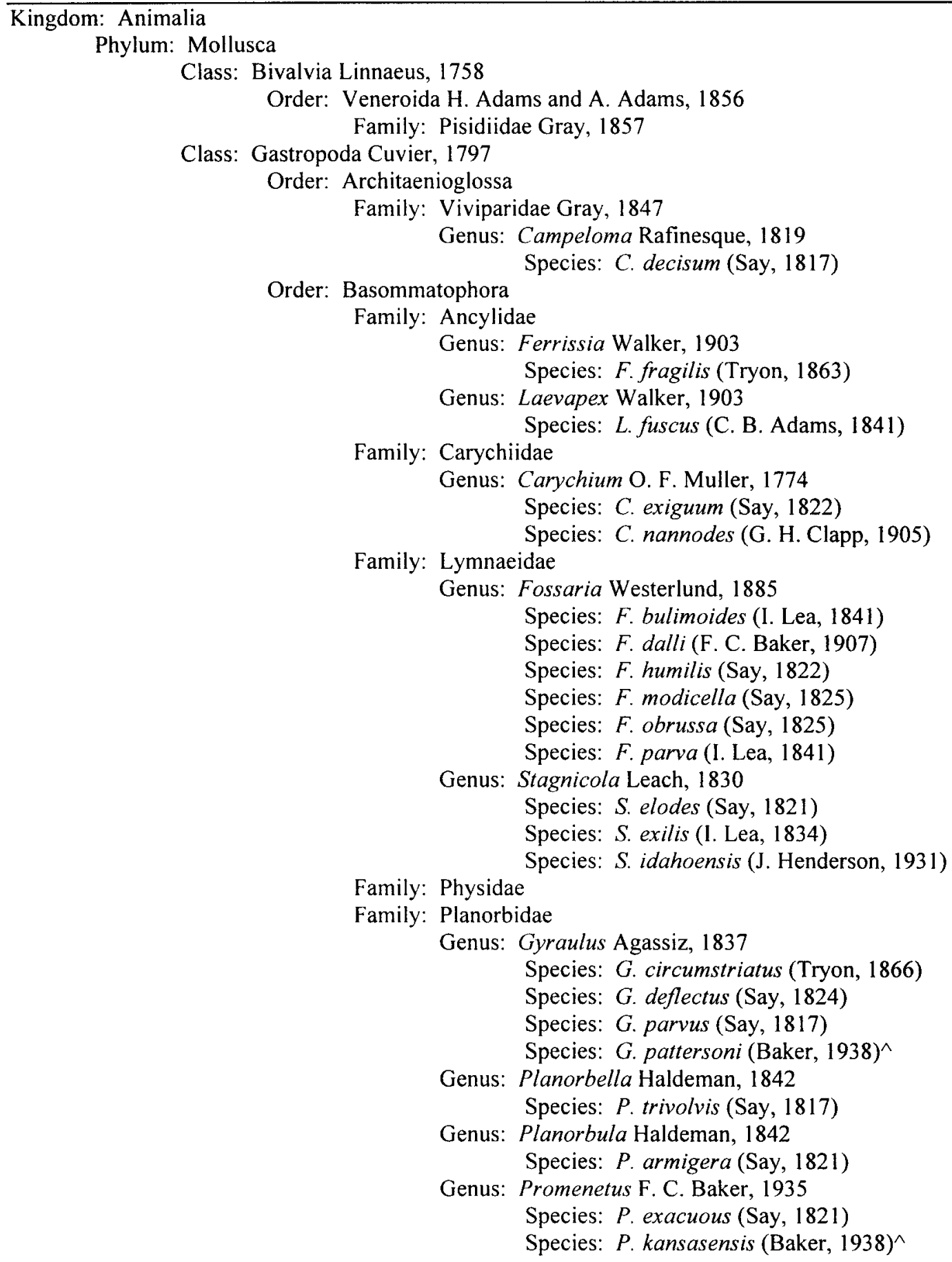




\section{Appendix 3 Continued}

Order: Heterostropha

Family: Valvatidae

Genus: Valvata O. F. Muller, 1774

Species: V. tricarinata (Say, 1817)

Order: Neotaenioglossa

Family: Hydrobiidae Simpson, 1865

Genus: Amnicola Gould and Haldeman, 1841

Species: A. granum (Say, 1822)

Genus: Cincinnatia Pilsbry, 1891

Species: C. cincinnatiensis (Anthony, 1840)

Species: C. mica (F. G. Thompson, 1968)

Order: Stylommatophora

Family: Cionellidae

Genus: Cionella Jeffreys, 1829

Species: C. lubrica (Muller, 1774)

Family: Discidae

Genus: Discus Fitzinger, 1833

Species: D. whitneyi (Newcomb, 1864)

Family: Helicarionidae

Genus: Euconulus Reinhardt, 1883

Species: E. fulvus (Muller, 1774)

Family: Helicodiscidae

Genus: Helicodiscus E. S. Morse, 1864

Species: H. parallelus (Say, 1817)

Species: H. singleyanus (Pilsbry, 1889)

Family: Limacidae

Genus: Deroceras Rafinesque, 1820

Species: D. laeve (Muller, 1774)

Family: Polygyridae

Genus: Euchemotrema Archer, 1939

Species: E. fraternum (Say, 1824)

Family: Punctidae

Species: Euchemotrema sp.

Genus: Punctum E. S. Morse, 1864

Species: P. minutissimum (I. Lea, 1841)

Family: Pupillidae

Genus: Gastrocopta Wollaston, 1878

Species: G. armifera (Say, 1821)

Species: G. contracta (Say, 1822)

Species: G. cristata (Pilsbry and Vanatta, 1900)

Species: G. holzingeri (Sterki, 1889)

Species: G. pellucida (Pfeiffer, 1841)

Species: G. pentodon (Say, 1822)

Species: G. proarmifera $($ Leonard, 1946)^

Species: $G$. procera (Gould, 1840)

Species: G. riograndensis (Pilsbry, 1916)

Species: G. rupicola (Say, 1821)

Species: G. scaevoscala (Taylor, 1960) ${ }^{\wedge}$

Species: G. tappaniana (C. B. Adams, 1842) 


\section{Appendix 3 Continued}

Genus: Pupilla Leach, 1828

Species: P. blandi E. S. Morse, 1865

Species: P. muscorum (Linnaeus, 1758)

Genus: Pupoides L. Pfeiffer, 1854

Species: P. albilabris (C. B. Adams, 1841)

Species: P. modicus (Gould, 1848)

Genus: Vertigo O. F. Muller, 1774

Species: V. elatior (Sterki, 1894)

Species: V. milium (Gould, 1840)

Species: V. ovata (Say, 1822)

Species: V. rugosula (Sterki, 1890)

Family: Strobilopsidae

Genus: Strobilops Pilsbry, 1893

Species: S. labyrinthicus (Say, 1817)

Family: Succineidae

Family: Valloniidae

Genus: Vallonia Risso, 1826

Species: V. cyclophorella (Sterki, 1892)

Species: V. gracilicosta (Reinhardt, 1883)

Species: V. parvula (Sterki, 1893)

Species: V. perspectiva (Sterki, 1893)

Species: V. pulchella (Muller, 1774)

Family: Zonitidae

Genus: Hawaiia Gude, 1911

Species: H. minuscula (A. Binney, 1841)

Genus: Nesovitrea C. M. Cooke, 1921

Species: N. electrina (Gould, 1841)

Genus: Zonitoides Lehmann, 1862

Species: Z. arboreus (Say, 1816) 


\section{Appendix 4}

Molluscan Synonymy. A list of the taxa used in this study to build the Molluscan Biogeography Database and the older, synonymous names encountered in the literature. This Appendix is not intended to be a complete list of all synonymous names.

\begin{tabular}{|c|c|}
\hline $\begin{array}{l}\text { CURRENT NAME USED IN } \\
\text { THIS STUDY } \\
\end{array}$ & SYNONYMS USED IN THIS STUDY \\
\hline Amnicola granum & Amnicola grana \\
\hline Campeloma decisum & Campeloma integrum, Campeloma lewisi \\
\hline Carychium exiguum & Carychium exigaum \\
\hline Cincinnatia cincinnatiensis & Annicola cincinnatiensis, Cincinnatia integra \\
\hline Cionella lubrica & Cochlicopa lubrica \\
\hline Deroceras laeve & Deroceras gracile \\
\hline Discus whitneyi & Discus cronkhitei \\
\hline Euchemotrema fraternum & Stenotrema fraternum \\
\hline Euconulus fulvus & Zonites fulvus \\
\hline Ferrissia fragilis & Ferrissa novangliae, Gundlachia meekiana \\
\hline Fossaria bulimoides & Galba bulimoides, Lymnaea bulimoides \\
\hline Fossaria dalli & Lymnaea dalli \\
\hline Fossaria humilis & Galba humilis, Lymnaea humilis \\
\hline Fossaria obrussa & Galba obrussa, Limnaea desidiosa, Limnophysa desidiosa, Lymnaea obrussa \\
\hline Fossaria parva & Galba parva, Lymnaea \\
\hline Gastrocopta armifera & Bifidaria armifera, Leucochila armifera, Pupa armifera \\
\hline $\begin{array}{l}\text { Gastrocopta contracta } \\
\text { Gastrocopta holzingeri }\end{array}$ & $\begin{array}{c}\text { Bifidaria contracta, Leucochila contracta, Pupa contracta, Pupilla contracta } \\
\text { Bifidaria holzingeri }\end{array}$ \\
\hline Gastrocopta pentodon & $\begin{array}{c}\text { Bifidaria pentodon, Leucochila pentodon, Pupa pentodon, Pupilla pentodon, } \\
\text { Vertigo pentodon }\end{array}$ \\
\hline Gastrocopta procera & Bifidaria procera, Pupa procera \\
\hline Gastrocopta rupicola & Leucochila rupicola, Pupa rupicola, Pupilla rupicola \\
\hline Gastrocopta tappaniana & Bifidaria tappaniana \\
\hline Gyraulus circumstriatus & Planorbis circumstriatus \\
\hline Gyraulus deflectus & Gyraulus hirsutus, Planorbis deflectus \\
\hline Gyraulus parvus & Planorbis parvus \\
\hline Hawaiia minuscula & $\begin{array}{l}\text { Helix minuscula, Zonites minusculus, Zonitoides minuscula, Zonitoides } \\
\text { minusculus }\end{array}$ \\
\hline Helicodiscus parallelus & Helicodiscus lineata, Helicodiscus lineatus, Helix lineata, Helix lineatus \\
\hline Helicodiscus singleyanus & Zonites singleyanus, Zonitoides singleyana \\
\hline Laevapex fuscus & Ancylus fuscus, Ferrissia fusca, Ferrissia kirtlandi \\
\hline Nesovitrea electrina & Helix electrina, Retinella electrina \\
\hline Pisidiidae & Sphaeriidae \\
\hline Planorbella trivolvis & Helisoma trivolvis, Planorbis trivolvis \\
\hline Planorbula armigera & $\begin{array}{c}\text { Planorbella armigera, Planorbis armigerus, Planorbula jenksii, Segmentina } \\
\text { armigera, Segmentina wheatleyi }\end{array}$ \\
\hline $\begin{array}{l}\text { Promenetus exacuous } \\
\text { Punctum minutissimum }\end{array}$ & $\begin{array}{c}\text { Menetus exacuous, Mentus exacutus, Planorbis exacuous, Planorbis exacutus } \\
\text { Helix minutissima, Punctum pygmaeum }\end{array}$ \\
\hline Pupoides albilabris & Pupa albilabris, Pupoides marginata, Pupoides marginatus \\
\hline Stagnicola elodes & Lymnaea palustris \\
\hline Stagnicola exilis & Limnophysa zebra, Lymnaea exilis, Lymnaea zebra \\
\hline Strobilops labyrinthicus & Helix labyrinthica, Strobila labyrinthica, Strobilops labyrinthica \\
\hline Vallonia pulchella & Helix pulchella \\
\hline Vertigo ovata & Isthmia ovata \\
\hline Zonitoides arboreus & $\begin{array}{c}\text { Helix arboreus, Hyalina arborea, Zonites arboreus, Zonitoides arborea, } \\
\text { Zonitoides arboreus }\end{array}$ \\
\hline
\end{tabular}


Appendix 5

Raw Data. A list of all samples examined in this study and the taxa recovered from those samples. The numbers displayed are counts of shells recovered for each taxon within the various assemblages (see text for a discussion on the techniques used to count gastropod and bivalve shells). The column titled "Total Shells" is the summation of all the shells in that assemblage. Asterisk (*)-no shells of this taxon were recovered in that sample, $\mathrm{P}$-taxon was present but counts of shells are not available, $\mathrm{F}$ - freshwater taxon, $\mathrm{L}$-land taxon, caret $\left({ }^{\wedge}\right)$ _extinct taxon.

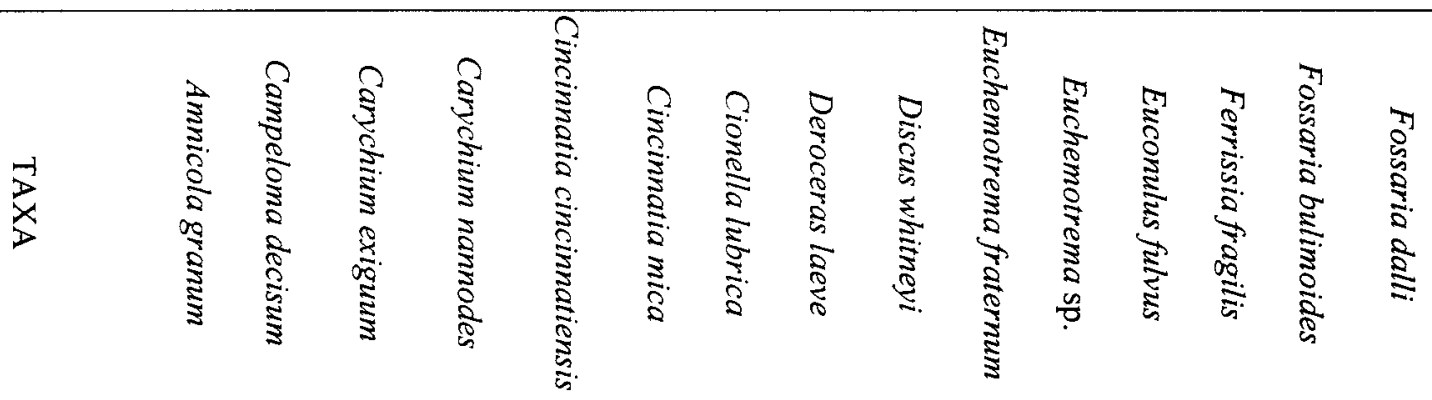

\begin{tabular}{|c|c|c|c|c|c|c|c|c|c|c|c|c|c|c|c|}
\hline $\begin{array}{l}\text { ASSEMBLAGE } \\
\text { CODES }\end{array}$ & $\mathrm{F}$ & $\mathrm{F}$ & $\mathrm{L}$ & $\mathrm{L}$ & $\mathrm{F}$ & $F$ & $\mathrm{~L}$ & $\mathrm{~L}$ & $\mathrm{~L}$ & $\mathrm{~L}$ & $\mathrm{~L}$ & $\mathrm{~L}$ & $\mathrm{~F}$ & $F$ & F \\
\hline RNT & $*$ & * & * & * & $*$ & $*$ & $*$ & $\mathrm{P}$ & * & $*$ & * & $*$ & $*$ & $P$ & $P$ \\
\hline RTB & $*$ & $*$ & 77 & $*$ & $*$ & $*$ & $*$ & 9 & $*$ & $*$ & $*$ & $*$ & $*$ & $*$ & 21 \\
\hline RTA & $*$ & $*$ & 4 & $*$ & $*$ & $*$ & $*$ & 3 & * & $*$ & $*$ & $*$ & 1 & $*$ & $*$ \\
\hline BDL & $*$ & $*$ & 21 & $*$ & $*$ & $*$ & $*$ & 58 & $*$ & $*$ & $*$ & $*$ & $*$ & $*$ & 401 \\
\hline CL2 & $*$ & $*$ & $*$ & $*$ & $*$ & $*$ & $*$ & $*$ & * & $*$ & $*$ & $*$ & $*$ & $*$ & $*$ \\
\hline CL1 & $*$ & $*$ & 30 & $*$ & $*$ & $*$ & $*$ & 2 & 1 & $*$ & $*$ & $*$ & $*$ & $*$ & 4 \\
\hline $\mathrm{BD} 2$ & $*$ & $*$ & $*$ & $*$ & $*$ & $*$ & $*$ & $*$ & $*$ & $*$ & $*$ & $*$ & $*$ & $*$ & $*$ \\
\hline $\mathrm{JQB}$ & $*$ & $*$ & 1 & $*$ & $*$ & 12 & $*$ & 1 & * & $*$ & $*$ & $*$ & $*$ & $*$ & 1 \\
\hline JQA & 15 & $*$ & 14 & $*$ & $*$ & $*$ & $*$ & 5 & * & $*$ & $*$ & $*$ & $*$ & $*$ & $*$ \\
\hline M35 & $*$ & $*$ & $*$ & * & $*$ & $*$ & $*$ & 8 & * & $*$ & $*$ & $*$ & 3 & $*$ & $*$ \\
\hline SPB & $*$ & $*$ & $*$ & $*$ & $*$ & $*$ & $*$ & 44 & * & $*$ & $*$ & $*$ & $*$ & $*$ & * \\
\hline SPA & $*$ & $*$ & $*$ & $*$ & $*$ & $*$ & $*$ & 33 & * & $*$ & * & $*$ & $*$ & $*$ & $*$ \\
\hline CR7 & $*$ & 1 & $*$ & $*$ & $*$ & $*$ & $*$ & $*$ & $*$ & $*$ & $*$ & $*$ & $*$ & $*$ & $*$ \\
\hline $\mathrm{CO} 3 \mathrm{~B}$ & $*$ & $*$ & 7 & $*$ & $*$ & $*$ & $*$ & 4 & 5 & $*$ & * & $*$ & $*$ & $*$ & 56 \\
\hline $\mathrm{CO} 3 \mathrm{~A}$ & $*$ & * & 87 & $*$ & $*$ & $*$ & 3 & 11 & $*$ & $*$ & $*$ & $*$ & $*$ & $*$ & 83 \\
\hline $\mathrm{CH} 4$ & $*$ & $*$ & $*$ & $*$ & $*$ & $*$ & 3 & 3 & 1 & $*$ & * & $*$ & $*$ & $*$ & 1 \\
\hline CHY & $*$ & $*$ & 4998 & 374 & $*$ & $*$ & 8 & 670 & 185 & 2 & 46 & 17 & $*$ & $*$ & 611 \\
\hline PMA & $*$ & $*$ & $*$ & $*$ & $*$ & $*$ & $*$ & 11 & $*$ & $*$ & $*$ & $*$ & $*$ & $*$ & 191 \\
\hline B $1 B$ & $*$ & $*$ & $*$ & $*$ & $*$ & $*$ & $*$ & 20 & $*$ & $*$ & $*$ & $*$ & $*$ & $*$ & 8 \\
\hline $\mathrm{X} 1 \mathrm{E}$ & $*$ & $*$ & 214 & $*$ & $*$ & $*$ & $*$ & 54 & $*$ & $*$ & 1 & $*$ & $*$ & $*$ & $*$ \\
\hline $\mathrm{X} 2 \mathrm{~B}$ & $*$ & * & 4 & $*$ & $*$ & $*$ & $*$ & 2 & $*$ & $*$ & 1 & $*$ & $*$ & $*$ & 65 \\
\hline $\mathrm{R} 1 \mathrm{~A}$ & $*$ & $*$ & $*$ & $*$ & $*$ & $*$ & $*$ & $*$ & $*$ & $*$ & $*$ & $*$ & $*$ & $*$ & 8 \\
\hline RYA & $*$ & $*$ & $*$ & $*$ & 419 & $*$ & $*$ & $*$ & $*$ & $*$ & $*$ & $*$ & $*$ & $*$ & 5 \\
\hline RFX & $*$ & $*$ & $*$ & $*$ & $*$ & $*$ & $*$ & $*$ & $*$ & $*$ & $*$ & $*$ & $*$ & $*$ & 2431 \\
\hline TFC & $*$ & $*$ & $*$ & $*$ & $*$ & $*$ & $*$ & 1 & $*$ & $*$ & $*$ & $*$ & $*$ & $*$ & 20 \\
\hline FAL & $*$ & $*$ & $*$ & $*$ & 8202 & $*$ & $*$ & $*$ & $*$ & $*$ & $*$ & $*$ & $*$ & $*$ & $*$ \\
\hline $\mathrm{AGO}$ & $*$ & $*$ & $*$ & $*$ & $*$ & $*$ & $*$ & 100 & $*$ & $*$ & $*$ & $*$ & $*$ & $*$ & 585 \\
\hline
\end{tabular}




\section{Appendix 5 Continued}

\begin{tabular}{|c|c|c|c|c|c|c|c|c|c|c|c|c|c|c|c|}
\hline$\underset{3}{3}$ & 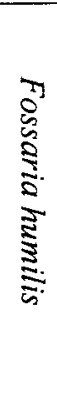 & 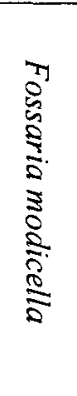 & 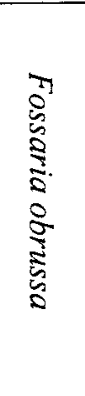 & 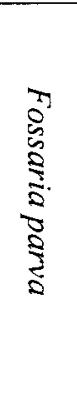 & 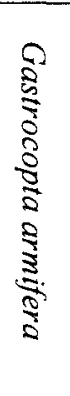 & 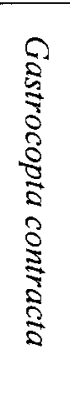 & 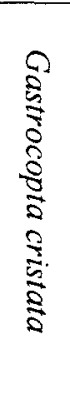 & 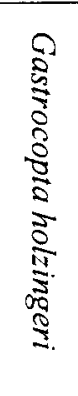 & 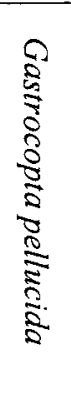 & 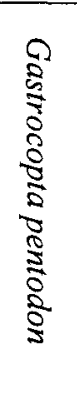 & 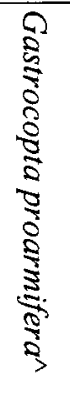 & 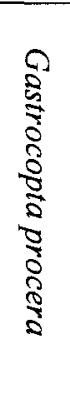 & 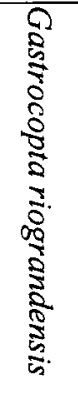 & 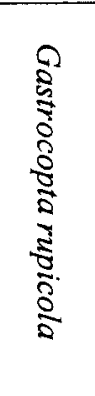 & 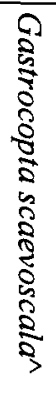 \\
\hline $\begin{array}{l}\text { ASSEMBLAGE } \\
\text { CODES }\end{array}$ & $\mathrm{F}$ & $\mathrm{F}$ & $\mathrm{F}$ & $F$ & $\mathrm{~L}$ & $\mathrm{~L}$ & $\mathrm{~L}$ & $\mathrm{~L}$ & $\mathrm{~L}$ & $\mathrm{~L}$ & $\mathrm{~L}$ & $\mathrm{~L}$ & $\mathrm{~L}$ & $\mathrm{~L}$ & $\mathrm{~L}$ \\
\hline RNT & $P$ & * & * & $P$ & $P$ & * & $\mathrm{P}$ & * & * & $*$ & $*$ & $P$ & $*$ & * & $*$ \\
\hline RTB & * & * & $*$ & * & 9 & * & * & 3 & 1 & 35 & 2 & 1 & * & * & $*$ \\
\hline RTA & * & * & $*$ & 10 & 1 & $*$ & 10 & 2 & $*$ & 8 & 4 & $*$ & $*$ & $*$ & $*$ \\
\hline BDL & * & $*$ & 80 & * & $*$ & * & * & $*$ & * & 59 & $*$ & * & * & $*$ & $*$ \\
\hline $\mathrm{CL} 2$ & $*$ & $*$ & 1 & $*$ & 4 & $*$ & $*$ & $*$ & 106 & $*$ & 15 & * & 4 & * & $*$ \\
\hline $\mathrm{CL} 1$ & $*$ & * & $*$ & * & $*$ & $*$ & $*$ & $*$ & $*$ & 10 & 3 & * & * & * & $*$ \\
\hline BD2 & $*$ & $*$ & $*$ & 305 & $*$ & $*$ & $*$ & $*$ & $*$ & $*$ & $*$ & * & $*$ & $*$ & $*$ \\
\hline JQB & $*$ & $*$ & $*$ & $*$ & 4 & $*$ & $*$ & * & 2 & * & $*$ & * & * & $*$ & $*$ \\
\hline JQA & $*$ & $*$ & 1 & 3 & 11 & 2 & 24 & 3 & 1 & 20 & * & * & * & * & $*$ \\
\hline M35 & * & * & * & 1 & $*$ & $*$ & $*$ & $*$ & 4 & * & $*$ & * & $*$ & * & $*$ \\
\hline SPB & $*$ & 135 & * & 23 & $*$ & $*$ & 1 & * & $*$ & 28 & * & * & * & * & $*$ \\
\hline SPA & $*$ & $*$ & $*$ & * & $*$ & $*$ & 9 & $*$ & * & 1 & $*$ & $*$ & $*$ & $*$ & $*$ \\
\hline CR7 & $*$ & $*$ & 34 & 63 & 9 & $*$ & 4 & $*$ & $*$ & 1 & $*$ & 10 & $*$ & * & $*$ \\
\hline $\mathrm{CO} 3 \mathrm{~B}$ & $*$ & 13 & 33 & 75 & 14 & $*$ & $*$ & 26 & $*$ & 56 & $*$ & 1 & * & * & $*$ \\
\hline $\mathrm{CO} 3 \mathrm{~A}$ & $*$ & $*$ & $*$ & 5 & 2 & $*$ & * & 10 & $*$ & 25 & 1 & * & * & * & $*$ \\
\hline $\mathrm{CH} 4$ & * & $*$ & * & * & 10 & * & $*$ & 210 & $*$ & $*$ & 9 & * & * & $*$ & $*$ \\
\hline CHY & * & * & * & 68 & * & * & * & * & * & 617 & * & * & $*$ & * & $*$ \\
\hline PMA & * & * & 523 & $*$ & $*$ & $*$ & * & * & $*$ & 23 & $*$ & * & 198 & 42 & 38 \\
\hline $\mathrm{B} 1 \mathrm{~B}$ & $*$ & $*$ & $*$ & $*$ & $*$ & $*$ & 101 & $*$ & $*$ & * & $*$ & $*$ & $*$ & 1719 & $*$ \\
\hline$X 1 E$ & * & * & * & $*$ & * & 10 & 62 & 4 & * & 122 & $*$ & 147 & $*$ & * & $*$ \\
\hline $\mathrm{X} 2 \mathrm{~B}$ & $*$ & $*$ & $*$ & $*$ & * & $*$ & $*$ & $*$ & 1 & $*$ & $*$ & 1 & 86 & $*$ & $*$ \\
\hline $\mathrm{R} 1 \mathrm{~A}$ & $*$ & $*$ & 98 & 12 & $*$ & $*$ & $*$ & * & 22 & * & * & * & 14 & * & $*$ \\
\hline RYA & $*$ & $*$ & * & * & $*$ & $*$ & 124 & $*$ & $*$ & $*$ & $*$ & * & $*$ & $*$ & $*$ \\
\hline RFX & * & * & 30 & 941 & * & $*$ & 544 & * & * & * & * & * & 11 & * & * \\
\hline TFC & * & * & 91 & * & * & * & * & * & $*$ & 1 & * & 29 & * & $*$ & * \\
\hline FAL & $*$ & $*$ & 230 & 55 & $*$ & $*$ & $*$ & $*$ & $*$ & $*$ & $*$ & $*$ & 5 & $*$ & $*$ \\
\hline AGO & * & $*$ & $*$ & $*$ & * & $*$ & $*$ & $*$ & $*$ & $*$ & $*$ & 5 & 678 & $*$ & $*$ \\
\hline
\end{tabular}


Appendix 5 Continued

\begin{tabular}{|c|c|c|c|c|c|c|c|c|c|c|c|c|c|c|c|}
\hline$\underset{b}{\vec{x}}$ & 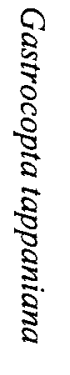 & 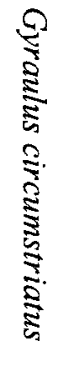 & 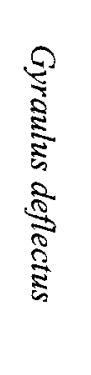 & 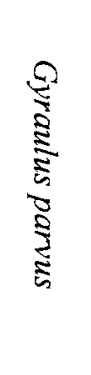 & 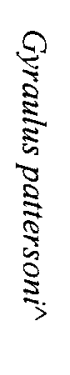 & 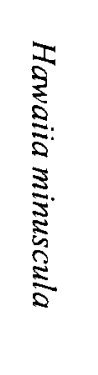 & 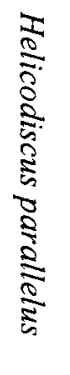 & 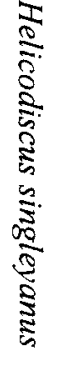 & 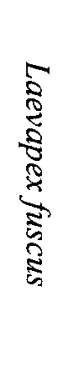 & 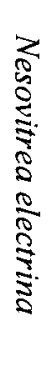 & 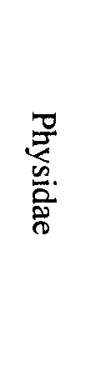 & 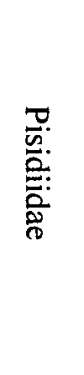 & 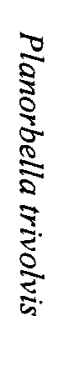 & 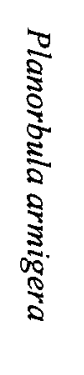 & 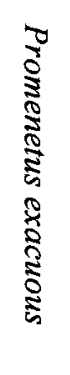 \\
\hline $\begin{array}{c}\text { ASSEMBLAGE } \\
\text { CODES }\end{array}$ & $\mathrm{L}$ & $\mathrm{F}$ & $\mathrm{F}$ & $\mathrm{F}$ & $\mathrm{F}$ & $\mathrm{L}$ & $\mathrm{L}$ & $\mathrm{L}$ & $\mathrm{F}$ & $\mathrm{L}$ & $\mathrm{F}$ & $\mathrm{F}$ & $\mathrm{F}$ & $\mathrm{F}$ & $\mathrm{F}$ \\
\hline RNT & $P$ & $P$ & $*$ & $\mathrm{P}$ & * & $P$ & $*$ & $\mathrm{P}$ & * & $*$ & $P$ & $\mathrm{P}$ & $\bar{P}$ & * & $P$ \\
\hline RTB & 19 & * & * & 1 & $*$ & 60 & 2 & $*$ & * & $*$ & 2 & 4 & $*$ & * & $*$ \\
\hline RTA & $*$ & * & * & 1 & * & 29 & 2 & $*$ & * & $*$ & 17 & 1 & 1 & * & $*$ \\
\hline BDL & 6 & 224 & * & $*$ & * & * & * & $*$ & $*$ & $*$ & 7 & 39 & * & $*$ & $*$ \\
\hline CL2 & $*$ & $*$ & $*$ & 4 & * & 7 & * & $*$ & * & $*$ & * & $*$ & * & $*$ & $*$ \\
\hline CLl & $*$ & $*$ & $*$ & 2 & * & * & * & $*$ & * & $*$ & * & 7 & * & * & $*$ \\
\hline BD2 & 3 & $*$ & * & 3 & $*$ & * & * & $*$ & $*$ & $*$ & * & * & * & $*$ & $*$ \\
\hline JQB & * & * & * & 4 & * & 7 & * & * & * & $*$ & $*$ & 4 & * & $*$ & 2 \\
\hline JQA & $*$ & * & * & 158 & * & 69 & * & $*$ & 1 & $*$ & 52 & 13 & * & * & 55 \\
\hline M35 & $*$ & * & $*$ & 13 & $*$ & $*$ & * & $*$ & * & $*$ & 1 & 1 & * & * & $*$ \\
\hline SPB & * & * & * & * & * & * & * & $*$ & * & $*$ & 19 & * & * & * & $*$ \\
\hline SPA & $*$ & $*$ & $*$ & $*$ & $*$ & $*$ & * & $*$ & $*$ & * & 64 & * & * & * & $*$ \\
\hline CR7 & * & * & * & 522 & 2 & 38 & * & * & * & $*$ & 33 & 1 & * & 48 & 134 \\
\hline $\mathrm{CO} 3 \mathrm{~B}$ & $*$ & $*$ & $*$ & 1090 & 35 & 93 & 4 & $*$ & $*$ & 5 & 162 & 47 & 9 & 160 & 754 \\
\hline $\mathrm{CO} 3 \mathrm{~A}$ & * & * & * & 3 & $*$ & $*$ & 3 & $*$ & * & 16 & $*$ & $*$ & $*$ & $*$ & $*$ \\
\hline $\mathrm{CH} 4$ & * & * & * & * & $*$ & 32 & 6 & $*$ & * & $*$ & * & * & * & * & 1 \\
\hline CHY & * & * & 130 & * & 11 & 100 & * & $*$ & * & 30 & 244 & 340 & * & * & $*$ \\
\hline PMA & * & * & * & 4853 & $*$ & 420 & * & $*$ & * & $*$ & 178 & 1 & * & * & 388 \\
\hline BIB & $*$ & * & 13 & * & * & 2664 & $*$ & 3 & * & $*$ & $*$ & $*$ & * & $*$ & $*$ \\
\hline $\mathrm{X} 1 \mathrm{E}$ & $*$ & * & $*$ & * & $*$ & 169 & 43 & $*$ & * & $*$ & * & * & * & * & $*$ \\
\hline $\mathrm{X} 2 \mathrm{~B}$ & * & * & * & 3484 & * & 5 & * & 2 & * & * & 2356 & * & * & * & $*$ \\
\hline $\mathrm{R} 1 \mathrm{~A}$ & $*$ & $*$ & $*$ & 353 & $*$ & 77 & $*$ & $*$ & $*$ & $*$ & 42 & $*$ & $*$ & $*$ & $*$ \\
\hline RYA & $*$ & $*$ & $*$ & $*$ & * & 144 & * & * & * & * & 3 & $*$ & $*$ & $*$ & $*$ \\
\hline RFX & * & * & 7130 & $*$ & * & 397 & * & * & * & * & 1482 & * & * & * & $*$ \\
\hline TFC & $*$ & $*$ & $*$ & * & * & 6 & * & $*$ & * & $*$ & 303 & $*$ & $*$ & * & $*$ \\
\hline FAL & $*$ & $*$ & * & 3065 & $*$ & * & * & $*$ & * & $*$ & 3027 & $*$ & * & * & $*$ \\
\hline $\mathrm{AGO}$ & $*$ & $*$ & $*$ & $*$ & $*$ & 282 & * & $*$ & * & $*$ & $*$ & $*$ & $*$ & * & $*$ \\
\hline
\end{tabular}




\section{Appendix 5 Continued}

\begin{tabular}{|c|c|c|c|c|c|c|c|c|c|c|c|c|c|c|c|}
\hline$\underset{D}{\vec{x}}$ & 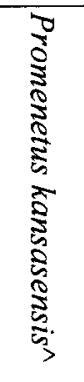 & 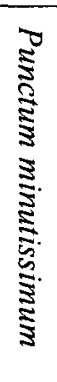 & 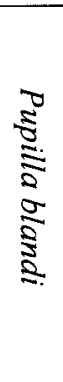 & 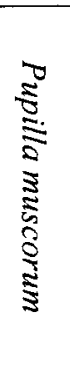 & 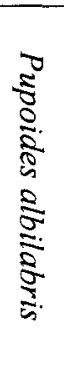 & 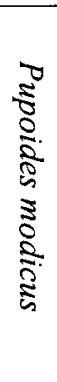 & 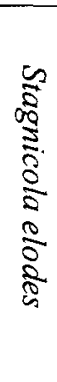 & 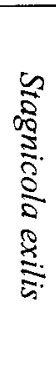 & 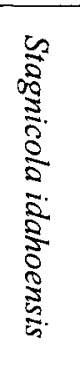 & 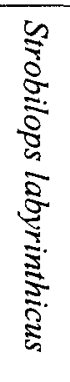 & 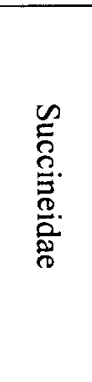 & 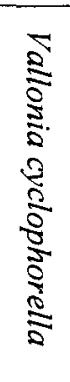 & 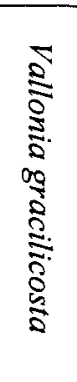 & 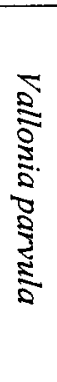 & 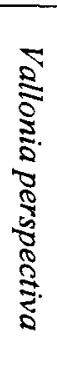 \\
\hline $\begin{array}{c}\text { ASSEMBLAGE } \\
\text { CODES }\end{array}$ & $\mathrm{F}$ & $\mathrm{L}$ & $\mathrm{L}$ & $\mathrm{L}$ & $\mathrm{L}$ & $\mathrm{L}$ & $\mathrm{F}$ & $\mathrm{F}$ & $F$ & $\mathrm{~L}$ & $\mathrm{~L}$ & $\mathrm{~L}$ & $\mathrm{~L}$ & $\mathrm{~L}$ & $\mathrm{~L}$ \\
\hline RNT & * & * & * & * & $\mathrm{P}$ & * & $*$ & * & * & $*$ & $\mathrm{P}$ & * & * & $*$ & $*$ \\
\hline rB & * & $*$ & 1 & * & $*$ & $*$ & $*$ & $*$ & * & 39 & 42 & $*$ & 8 & $*$ & 6 \\
\hline RTA & $*$ & $*$ & 7 & $*$ & $*$ & 1 & $*$ & $*$ & $*$ & * & 17 & $*$ & 6 & $*$ & 1 \\
\hline BDL & $*$ & $*$ & $*$ & 9 & * & $*$ & $*$ & * & $*$ & * & 1942 & 6 & 12 & $*$ & $*$ \\
\hline CL2 & * & $*$ & $*$ & $*$ & 10 & 11 & $*$ & $*$ & $*$ & $*$ & 10 & * & * & $*$ & 10 \\
\hline CL1 & * & * & $*$ & 2 & $*$ & $*$ & $*$ & * & $*$ & * & 10 & $*$ & 3 & $*$ & $*$ \\
\hline BD2 & * & $*$ & 36 & 18 & * & $*$ & $*$ & $*$ & * & $*$ & 45 & $*$ & 27 & $*$ & $*$ \\
\hline $\mathrm{JQB}$ & $*$ & $*$ & $*$ & $*$ & 1 & $*$ & * & * & * & $*$ & $*$ & $*$ & 6 & 12 & $*$ \\
\hline JQA & 8 & $*$ & $*$ & $*$ & 6 & $*$ & $*$ & $*$ & $*$ & $*$ & 4 & $*$ & 10 & 16 & $*$ \\
\hline M35 & * & $*$ & $*$ & $*$ & * & $*$ & $*$ & * & $*$ & * & 93 & * & $*$ & $*$ & * \\
\hline SPB & $*$ & $*$ & 7 & $*$ & $*$ & $*$ & 1 & * & $*$ & $*$ & 1041 & * & $*$ & $*$ & $*$ \\
\hline SPA & $*$ & $*$ & 39 & $*$ & $*$ & $*$ & $*$ & $*$ & $*$ & $*$ & 774 & $*$ & * & $*$ & $*$ \\
\hline $\mathrm{CR} 7$ & 48 & $*$ & $*$ & $*$ & 6 & * & $*$ & $*$ & $*$ & $*$ & 19 & * & $*$ & $*$ & 1 \\
\hline $\mathrm{CO} 3 \mathrm{~B}$ & 230 & 7 & $*$ & $*$ & * & * & * & * & * & 1 & 84 & * & 9 & $*$ & 11 \\
\hline $\mathrm{CO} 3 \mathrm{~A}$ & $*$ & 72 & $*$ & $*$ & $*$ & $*$ & $*$ & $*$ & $*$ & $*$ & 29 & $*$ & 47 & $*$ & 13 \\
\hline $\mathrm{CH} 4$ & * & 37 & * & $*$ & * & $*$ & $*$ & $*$ & * & $*$ & 36 & 6 & 53 & $*$ & 50 \\
\hline $\mathrm{CHY}$ & * & 8 & $*$ & 176 & $*$ & * & * & * & $*$ & 119 & 425 & 173 & 843 & $*$ & $*$ \\
\hline PMA & 35 & $*$ & * & $*$ & 24 & $*$ & $*$ & $*$ & 190 & $*$ & 252 & $*$ & $*$ & $*$ & $*$ \\
\hline B & $*$ & $*$ & $*$ & $*$ & 29 & $*$ & $*$ & $*$ & $*$ & $*$ & 17 & * & * & 3 & $*$ \\
\hline$X$ & * & $*$ & $*$ & $*$ & $*$ & * & $*$ & $*$ & * & 12 & 25 & * & $*$ & $*$ & $*$ \\
\hline $\mathrm{X} 2 \mathrm{~B}$ & * & $*$ & $*$ & * & 1 & $*$ & $*$ & $*$ & $*$ & $*$ & 14 & $*$ & $*$ & $*$ & $*$ \\
\hline $\mathrm{R} 1 \mathrm{~A}$ & * & $*$ & $*$ & $*$ & * & * & $*$ & * & $*$ & * & 5 & $*$ & $*$ & $*$ & $*$ \\
\hline RYA & * & * & $*$ & * & * & * & * & * & * & * & 1 & * & $*$ & $*$ & $*$ \\
\hline RFX & $*$ & $*$ & $*$ & $*$ & * & $*$ & $*$ & * & * & * & 4 & * & * & $*$ & * \\
\hline TFC & * & $*$ & $*$ & $*$ & $*$ & $*$ & $*$ & 11 & * & $*$ & 2 & * & * & $*$ & ${ }^{*}$ \\
\hline FAL & $*$ & $*$ & * & $*$ & * & $*$ & $*$ & $*$ & $*$ & $*$ & 1 & $*$ & * & $*$ & * \\
\hline AGO & * & * & $*$ & * & $*$ & * & * & $*$ & $*$ & * & $*$ & * & $*$ & $*$ & $*$ \\
\hline
\end{tabular}




\section{Appendix 5 Continued}

\begin{tabular}{|c|c|c|c|c|c|c|c|c|}
\hline$\underset{d}{\vec{x}}$ & 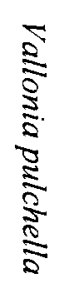 & $\begin{array}{l}5 \\
5 \\
\vdots \\
\vdots \\
\vdots \\
\vdots \\
\vdots \\
\vdots \\
\vdots \\
\vdots \\
\vdots\end{array}$ & 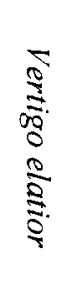 & 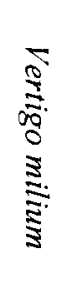 & 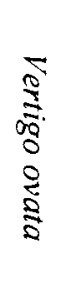 & 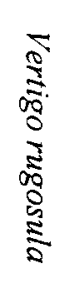 & 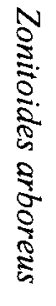 & \\
\hline $\begin{array}{c}\text { ASSEMBLAGE } \\
\text { CODES }\end{array}$ & $\mathrm{L}$ & $\mathrm{F}$ & $\mathrm{L}$ & $\mathrm{L}$ & $\mathrm{L}$ & $\mathrm{L}$ & $\mathrm{L}$ & $\begin{array}{l}\text { TOTAL } \\
\text { SHELLS }\end{array}$ \\
\hline RNT & $*$ & $*$ & $*$ & $*$ & $P$ & * & $*$ & $P$ \\
\hline RTB & * & $*$ & 1 & 13 & $*$ & 7 & 2 & 365 \\
\hline RTA & * & $*$ & 5 & 3 & $*$ & * & $*$ & 134 \\
\hline BDL & $*$ & $*$ & $*$ & 163 & 183 & 149 & $*$ & 3359 \\
\hline CL2 & * & $*$ & $*$ & $*$ & $*$ & 1 & $*$ & 183 \\
\hline CL1 & $*$ & $*$ & 8 & 3 & * & * & $*$ & 85 \\
\hline BD2 & $*$ & $*$ & $*$ & 1 & 1 & * & $*$ & 439 \\
\hline JQB & $*$ & 3 & $*$ & * & 2 & * & $*$ & 62 \\
\hline JQA & $*$ & 54 & $*$ & $*$ & 11 & $*$ & $*$ & 556 \\
\hline M35 & $*$ & $*$ & $*$ & * & * & * & $*$ & 124 \\
\hline SPB & * & $*$ & $*$ & * & * & * & $*$ & 1299 \\
\hline SPA & $*$ & $*$ & * & * & 1 & * & * & 921 \\
\hline CR7 & $*$ & $*$ & $*$ & $*$ & * & 4 & $*$ & 978 \\
\hline $\mathrm{CO} 3 \mathrm{~B}$ & 13 & $*$ & $*$ & $*$ & 35 & 15 & $*$ & 3054 \\
\hline $\mathrm{CO} 3 \mathrm{~A}$ & 31 & $*$ & $*$ & $*$ & * & * & $*$ & 441 \\
\hline $\mathrm{CH} 4$ & $*$ & $*$ & $*$ & $*$ & $*$ & $*$ & 2 & 460 \\
\hline CHY & 37 & $*$ & 165 & 976 & 89 & 75 & 8 & 11545 \\
\hline PMA & $*$ & $*$ & * & 50 & 1 & 1 & $*$ & 7419 \\
\hline $\mathrm{B} 1 \mathrm{~B}$ & $*$ & $*$ & $*$ & 461 & * & * & * & 5038 \\
\hline$X 1 E$ & * & $*$ & * & 166 & * & * & $*$ & 1029 \\
\hline $\mathrm{X} 2 \mathrm{~B}$ & $*$ & $*$ & $*$ & $*$ & $*$ & $*$ & $*$ & 6022 \\
\hline $\mathrm{R} 1 \mathrm{~A}$ & * & * & $*$ & $*$ & $*$ & $*$ & $*$ & 631 \\
\hline RYA & $*$ & * & $*$ & 3 & $*$ & $*$ & $*$ & 699 \\
\hline RFX & * & $*$ & $*$ & $*$ & $*$ & $*$ & $*$ & 12970 \\
\hline TFC & * & $*$ & $*$ & $*$ & $*$ & $*$ & $*$ & 464 \\
\hline FAL & * & $*$ & $*$ & $*$ & $*$ & $*$ & $*$ & 14585 \\
\hline $\mathrm{AGO}$ & $*$ & $*$ & * & 604 & $*$ & 2 & $*$ & 2256 \\
\hline
\end{tabular}


Appendix 6

Assemblage Turnover. Jaccard Index values generated by comparing each assemblage to every other assemblage. The diagonal of ones (1.00) results from each assemblage being compared to itself, which must equal one by definition. Asterisk $\left({ }^{*}\right)$ no data/redundant number.

\begin{tabular}{ccccccccccccccc}
\hline & RNT & RTB & RTA & BDL & CL2 & CL1 & BD2 & JQB & JQA & M35 & SPB & SPA & CR7 & CO3B \\
\hline RNT & $\mathbf{1 . 0 0}$ & 0.29 & 0.31 & 0.29 & 0.19 & 0.18 & 0.21 & 0.35 & 0.38 & 0.27 & 0.21 & 0.23 & 0.39 & 0.35 \\
RTB & $*$ & $\mathbf{1 . 0 0}$ & 0.53 & 0.38 & 0.29 & 0.42 & 0.18 & 0.30 & 0.33 & 0.23 & 0.18 & 0.19 & 0.30 & 0.46 \\
RTA & $*$ & $*$ & $\mathbf{1 . 0 0}$ & 0.27 & 0.26 & 0.40 & 0.24 & 0.23 & 0.39 & 0.30 & 0.29 & 0.26 & 0.32 & 0.41 \\
BDL & $*$ & $*$ & $*$ & $\mathbf{1 . 0 0}$ & 0.08 & 0.45 & 0.32 & 0.24 & 0.29 & 0.20 & 0.19 & 0.28 & 0.21 & 0.31 \\
CL2 & $*$ & $*$ & $*$ & $*$ & $\mathbf{1 . 0 0}$ & 0.14 & 0.11 & 0.23 & 0.24 & 0.18 & 0.05 & 0.06 & 0.35 & 0.20 \\
CL1 & $*$ & $*$ & $*$ & $*$ & $*$ & $\mathbf{1 . 0 0}$ & 0.29 & 0.27 & 0.23 & 0.24 & 0.16 & 0.18 & 0.14 & 0.26 \\
BD2 & $*$ & $*$ & $*$ & $*$ & $*$ & $*$ & $\mathbf{1 . 0 0}$ & 0.14 & 0.18 & 0.21 & 0.20 & 0.23 & 0.12 & 0.15 \\
JQB & $*$ & $*$ & $*$ & $*$ & $*$ & $*$ & $*$ & $\mathbf{1 . 0 0}$ & 0.39 & 0.21 & 0.04 & 0.10 & 0.21 & 0.29 \\
JQA & $*$ & $*$ & $*$ & $*$ & $*$ & $*$ & $*$ & $*$ & $\mathbf{1 . 0 0}$ & 0.28 & 0.22 & 0.24 & 0.43 & 0.42 \\
M35 & $*$ & $*$ & $*$ & $*$ & $*$ & $*$ & $*$ & $*$ & $*$ & $\mathbf{1 . 0 0}$ & 0.31 & 0.25 & 0.23 & 0.19 \\
SPB & $*$ & $*$ & $*$ & $*$ & $*$ & $*$ & $*$ & $*$ & $*$ & $*$ & $\mathbf{1 . 0 0}$ & 0.60 & 0.22 & 0.18 \\
SPA & $*$ & $*$ & $*$ & $*$ & $*$ & $*$ & $*$ & $*$ & $*$ & $*$ & $*$ & $\mathbf{1 . 0 0}$ & 0.18 & 0.16 \\
CR7 & $*$ & $*$ & $*$ & $*$ & $*$ & $*$ & $*$ & $*$ & $*$ & $*$ & $*$ & $*$ & $\mathbf{1 . 0 0}$ & 0.48 \\
CO3B & $*$ & $*$ & $*$ & $*$ & $*$ & $*$ & $*$ & $*$ & $*$ & $*$ & $*$ & $*$ & $*$ & $\mathbf{1 . 0 0}$ \\
CO3A & $*$ & $*$ & $*$ & $*$ & $*$ & $*$ & $*$ & $*$ & $*$ & $*$ & $*$ & $*$ & $*$ & $*$ \\
CH4 & $*$ & $*$ & $*$ & $*$ & $*$ & $*$ & $*$ & $*$ & $*$ & $*$ & $*$ & $*$ & $*$ & $*$ \\
CHY & $*$ & $*$ & $*$ & $*$ & $*$ & $*$ & $*$ & $*$ & $*$ & $*$ & $*$ & $*$ & $*$ & $*$ \\
PMA & $*$ & $*$ & $*$ & $*$ & $*$ & $*$ & $*$ & $*$ & $*$ & $*$ & $*$ & $*$ & $*$ & $*$ \\
B1B & $*$ & $*$ & $*$ & $*$ & $*$ & $*$ & $*$ & $*$ & $*$ & $*$ & $*$ & $*$ & $*$ & $*$ \\
X1E & $*$ & $*$ & $*$ & $*$ & $*$ & $*$ & $*$ & $*$ & $*$ & $*$ & $*$ & $*$ & $*$ & $*$ \\
X2B & $*$ & $*$ & $*$ & $*$ & $*$ & $*$ & $*$ & $*$ & $*$ & $*$ & $*$ & $*$ & $*$ & $*$ \\
R1A & $*$ & $*$ & $*$ & $*$ & $*$ & $*$ & $*$ & $*$ & $*$ & $*$ & $*$ & $*$ & $*$ & $*$ \\
RYA & $*$ & $*$ & $*$ & $*$ & $*$ & $*$ & $*$ & $*$ & $*$ & $*$ & $*$ & $*$ & $*$ & $*$ \\
RFX & $*$ & $*$ & $*$ & $*$ & $*$ & $*$ & $*$ & $*$ & $*$ & $*$ & $*$ & $*$ & $*$ & $*$ \\
TFC & $*$ & $*$ & $*$ & $*$ & $*$ & $*$ & $*$ & $*$ & $*$ & $*$ & $*$ & $*$ & $*$ & $*$ \\
FAL & $*$ & $*$ & $*$ & $*$ & $*$ & $*$ & $*$ & $*$ & $*$ & $*$ & $*$ & $*$ & $*$ & $*$ \\
AGO & $*$ & $*$ & $*$ & $*$ & $*$ & $*$ & $*$ & $*$ & $*$ & $*$ & $*$ & $*$ & $*$ & $*$ \\
\hline & & & & & & & & & & & & &
\end{tabular}




\section{Appendix 6 Continued}

\begin{tabular}{|c|c|c|c|c|c|c|c|c|c|c|c|c|c|}
\hline & $\mathrm{CO} 3 \mathrm{~A}$ & $\mathrm{CH} 4$ & $\mathrm{CHY}$ & PMA & $\mathrm{B} 1 \mathrm{~B}$ & $\mathrm{X} 1 \mathrm{E}$ & $\mathrm{X} 2 \mathrm{~B}$ & $\mathrm{R} 1 \mathrm{~A}$ & RYA & RFX & TFC & FAL & AGO \\
\hline RNT & 0.19 & 0.20 & 0.20 & 0.34 & 0.29 & 0.18 & 0.38 & 0.26 & 0.23 & 0.26 & 0.26 & 0.17 & 0.17 \\
\hline RTB & 0.41 & 0.38 & 0.36 & & 0.17 & 0.37 & 0.32 & 0.22 & 0.19 & 0.14 & 0.27 & 0.11 & 0.24 \\
\hline RTA & 0.44 & .31 & 0.28 & 0.24 & 0.18 & 0.35 & 0.21 & & & 0.19 & 0.19 & & 0.12 \\
\hline BDL & 0.22 & 0.19 & 0.41 & 0.40 & 0.17 & 0.21 & 0.21 & 0.19 & 0.21 & 0.19 & & & 0.21 \\
\hline CL2 & 0.21 & 0.22 & 0.08 & 0.29 & 0.15 & 0.09 & 0.32 & 0.40 & 0.12 & 0.24 & 0.17 & 0.27 & 0.19 \\
\hline CL1 & 0.36 & 0.26 & 0.35 & 0.28 & 0.20 & 0.24 & 0.24 & 0.16 & 0.18 & 0.10 & 0.22 & 0.11 & 0.18 \\
\hline BD2 & & 0.09 & 0.19 & 0.12 & 0.11 & 0.10 & 0.10 & 0.20 & 0.14 & 0.13 & 0.06 & 0.23 & 0.07 \\
\hline JQB & & 0.24 & 0.19 & 0.31 & 0.24 & 0.12 & 0.33 & 0.20 & 0.10 & 0.09 & 0.14 & .05 & 0.16 \\
\hline JQA & 0 & 0.21 & 0.2 & 0.3 & 0.21 & 0.28 & 0.28 & 0 . & 0.15 & 0.22 & 0.22 & 0.19 & 0.07 \\
\hline M35 & & 0.09 & 0.1 & 0.2 & 0.12 & 0.11 & 0.31 & 0. & 0.15 & 0.21 & 0.21 & .36 & 0.07 \\
\hline SPB & & 0.09 & 0.15 & 0.1 & 0.18 & 0.22 & 0.16 & 0.20 & 0.23 & 0.29 & 0.29 & .23 & 0.07 \\
\hline SPA & & 0.10 & 0.16 & 0.2 & 0.20 & 0.25 & 0.18 & 0. & 0.27 & 0.23 & 0.33 & 17 & 0.08 \\
\hline CR7 & & $0.1^{\prime}$ & 0.2 & 0.4 & 0.15 & 0.19 & 0.23 & 0.2 & 0.18 & 0.27 & 0.27 & 4 & 0.13 \\
\hline $\mathrm{CO} 3 \mathrm{~B}$ & 0.4 & 0.35 & 0.44 & 0.3 & 0.11 & 0.26 & 0.23 & 0.22 & 0.12 & 0.18 & 0.26 & 0.16 & 0.16 \\
\hline $\mathrm{CO} 3 \mathrm{~A}$ & 1.00 & 0.50 & 0.3 & 0.1 & 0.12 & 0.25 & 0.20 & 0.1 & 0.09 & 0.13 & 0.18 & 4 & 0.09 \\
\hline $\mathrm{CH} 4$ & . & 1.00 & 0.25 & $0.1^{\prime}$ & 0.17 & 0.21 & 0.16 & 0.14 & 0.15 & 0.14 & 0.19 & 0.05 & 0.15 \\
\hline $\mathrm{CHY}$ & * & 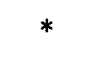 & 1.00 & 0.26 & 0.18 & 0.24 & 0.20 & 0.15 & 0.16 & 0.19 & 0.19 & 0.09 & 0.16 \\
\hline PMA & * & $*$ & 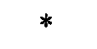 & 1.00 & 0.30 & 0.19 & 0.33 & 0.33 & 0.24 & 0.27 & 0.33 & .24 & 0.30 \\
\hline $\mathrm{B} 1 \mathrm{~B}$ & * & * & * & * & 1.00 & 0.26 & 0.33 & 0.18 & 0.38 & 0.33 & 0.25 & 0.06 & 0.29 \\
\hline $\mathrm{X} 1 \mathrm{E}$ & * & * & $*$ & * & $*$ & 1.00 & 0.30 & 0.10 & 0.25 & 0.16 & 0.29 & 0.05 & 0.25 \\
\hline $\mathrm{X} 2 \mathrm{~B}$ & $*$ & $*$ & $*$ & $*$ & * & $*$ & 1.00 & 0.47 & 0.25 & 0.29 & 0.38 & 0.25 & 0.33 \\
\hline $\mathrm{R} 1 \mathrm{~A}$ & * & $*$ & * & $*$ & * & $*$ & $*$ & 1.0 & 0.33 & 0.64 & 0.38 & 0.60 & 0.23 \\
\hline RYA & $*$ & * & * & * & * & $*$ & $*$ & $*$ & 1.00 & 0.45 & 0.33 & 0.27 & 0.27 \\
\hline RFX & * & * & $*$ & * & $*$ & * & $*$ & * & $*$ & 1.00 & 0.38 & 0.45 & 0.23 \\
\hline TFC & $*$ & * & $*$ & $*$ & $*$ & * & * & * & $*$ & $*$ & 1.00 & 0.23 & 0.33 \\
\hline FAL & $*$ & $*$ & $*$ & $*$ & $*$ & * & * & * & $*$ & * & $*$ & 1.00 & 0.08 \\
\hline AGO & * & $*$ & $*$ & $*$ & * & * & * & * & * & * & $*$ & $*$ & 1.00 \\
\hline
\end{tabular}




\section{Appendix 7}

Appendix 7a. Summary of taxa and their environmental tolerances. Species names are abbreviated see Appendix 3 for the full names. ELEVTN - elevation, MinT - mean minimum temperature for January, MaxT-mean maximum temperature for July, PRECIP - mean annual precipitation, $\mathrm{n}$-number of counties a taxon is known from, $\mathrm{R}$-range displayed using the format "smallest value;largest value", $\mathbf{M}-$ mean value. See Appendix 1 for the meaning of the Vegetation codes.

\begin{tabular}{|c|c|c|c|c|c|c|c|c|c|c|}
\hline \multirow{2}{*}{ TAXA } & \multirow[b]{2}{*}{$\mathbf{n}$} & \multicolumn{2}{|c|}{$\operatorname{ELEVTN}(\mathrm{m})$} & \multicolumn{2}{|c|}{$\operatorname{MinT}\left({ }^{\circ} \mathrm{C}\right)$} & \multicolumn{2}{|c|}{$\operatorname{MaxT}\left({ }^{\circ} \mathrm{C}\right)$} & \multicolumn{2}{|c|}{ PRECIP $(\mathrm{cm})$} & \multirow{2}{*}{ VEGETATION } \\
\hline & & $\mathrm{R}$ & $\mathbf{M}$ & $\mathrm{R}$ & $\mathbf{M}$ & $\mathrm{R}$ & $\mathbf{M}$ & $\mathrm{R}$ & $\mathbf{M}$ & \\
\hline A. granum & 13 & 5,459 & 249 & $-14 ;-2$ & -9 & $26 ; 31$ & 28 & $76 ; 122$ & 100 & 2113211422122320 \\
\hline C. decisum & 192 & $5 ; 816$ & 209 & $-19 ; 5$ & -7 & $24 ; 35$ & 30 & $48 ; 137$ & 102 & $\begin{array}{c}21112112211321142211 \\
22122213221422152311 \\
2320251125122531\end{array}$ \\
\hline C. exiguum & 267 & $1 ; 1525$ & 257 & $-24 ; 16$ & -7 & $21 ; 37$ & 30 & $25 ; 157$ & 93 & $\begin{array}{l}21112112211321142211 \\
22122213221422152311 \\
23202511251225222523 \\
25312532253331123113 \\
321132124110 \\
\end{array}$ \\
\hline C. nannodes & 109 & $148 ; 1127$ & 363 & $-8 ; 2$ & -2 & $24 ; 34$ & 31 & $76 ; 168$ & 119 & 22112212221422152320 \\
\hline C. cincinnatiensis & 115 & $5 ; 638$ & 271 & $.22 ; 3$ & -9 & $25 ; 35$ & 31 & $38 ; 127$ & 87 & $\begin{array}{c}211321142211122122213 \\
22142215231223202511 \\
251225312532\end{array}$ \\
\hline C. mica & 1 & $31 ; 31$ & 31 & $6 ; 6$ & 6 & $33 ; 33$ & 33 & $127 ; 127$ & 127 & 2311 \\
\hline C. lubrica & 415 & $2 ; 3077$ & 424 & $-24 ; 6$ & -8 & $21 ; 39$ & 29 & $5 ; 147$ & 87 & $\begin{array}{c}21112112211321142211 \\
22122213221422152320 \\
25112531253225332610 \\
31113112311331403211 \\
32213222 \text { M2112 M2413 } \\
\text { M2414 M2610 M2620 } \\
\text { M3112 M3113 M3120 } \\
\text { P3131 P3132 }\end{array}$ \\
\hline D. laeve & 327 & $0 ; 2637$ & 361 & $-31 ; 23$ & -5 & $8 ; 39$ & 30 & $5 ; 348$ & 95 & $\begin{array}{c}12102111211321142211 \\
22122213221422152311 \\
23122320241025112512 \\
25212523253125332610 \\
31113112311331313133 \\
3221 \mathrm{~A} 3141 \mathrm{~A} 3142 \mathrm{M} 1310 \\
\mathrm{M} 2112 \mathrm{M} 2410 \mathrm{M} 2411 \\
\mathrm{M} 2412 \mathrm{M} 2413 \mathrm{M} 2414 \\
\mathrm{M} 2415 \mathrm{M} 2610 \mathrm{M} 2620 \\
\mathrm{M} 3112 \mathrm{M} 3113 \mathrm{M} 3120\end{array}$ \\
\hline D. whitneyi & 433 & $2 ; 2637$ & 478 & $-24 ; 3$ & -9 & $12 ; 39$ & 29 & $5 ; 274$ & 83 & $\begin{array}{c}21112112211321142211 \\
22122213221422152320 \\
25112512253125332610 \\
31113112311331313133 \\
314032113221 \text { A3141 } \\
\text { A3142 M1310 M2112 } \\
\text { M2410 M2411 M2610 } \\
\text { M3112 M3113 M3120 } \\
\text { P3131 P3132 }\end{array}$ \\
\hline E. fraternum & 557 & $5 ; 863$ & 263 & $-23 ; 2$ & -7 & $23 ; 36$ & 30 & $61 ; 168$ & 100 & $\begin{array}{l}21112112211321142211 \\
22122213221422152312 \\
23202511251225312533\end{array}$ \\
\hline E. fulvus & 449 & $5 ; 2637$ & 549 & $-24 ; 4$ & -8 & $12 ; 39$ & 30 & $5 ; 274$ & 83 & $\begin{array}{c}21112112211321142211 \\
22122213221422152320 \\
24102511251225312532 \\
25332610311131123113 \\
31313133313431403211 \\
321232213222 \mathrm{~A} 3141 \\
\mathrm{~A} 3142 \mathrm{M} 1310 \mathrm{M} 2112 \\
\mathrm{M} 2410 \mathrm{M} 2411 \mathrm{M} 2415 \\
\mathrm{M} 2610 \mathrm{M} 3112 \mathrm{M} 3113 \\
\mathrm{M} 3120 \mathrm{P} 3131 \mathrm{P} 3132\end{array}$ \\
\hline F. fragilis & 52 & $1: 1074$ & 193 & $-16: 4$ & -5 & $21: 34$ & 31 & $43 ; 274$ & 109 & $\begin{array}{c}21132114221122122213 \\
22142215231223202410 \\
251125313113 \mathrm{M} 2411\end{array}$ \\
\hline
\end{tabular}




\section{Appendix 7 Continued}

\begin{tabular}{|c|c|c|c|c|c|c|c|c|c|c|}
\hline \multirow{2}{*}{ TAXA } & \multirow{2}{*}{$\mathbf{n}$} & \multicolumn{2}{|c|}{ ELEVTN $(\mathrm{m})$} & \multicolumn{2}{|c|}{$\operatorname{MinT}\left({ }^{\circ} \mathrm{C}\right)$} & \multicolumn{2}{|c|}{$\operatorname{MaxT}\left({ }^{\circ} \mathrm{C}\right)$} & \multicolumn{2}{|c|}{ PRECIP (cm) } & \multirow{2}{*}{ VEGETATION } \\
\hline & & & & $\mathrm{R}$ & $\mathbf{M}$ & $\mathrm{R}$ & $\mathbf{M}$ & $\mathrm{R}$ & M & \\
\hline F. bulimoides & 103 & $12: 2652$ & 874 & $-22 ; 8$ & -7 & $23 ; 41$ & 33 & $5 ; 117$ & 57 & $\begin{array}{c}21112511251225222523 \\
25312533311332113212 \\
32213222 \mathrm{~A} 3142 \mathrm{M} 3112 \\
\mathrm{M} 3113 \mathrm{P} 3131 \mathrm{P} 3132\end{array}$ \\
\hline F. dalli & 37 & $167 ; 2185$ & 461 & $-23 ;-1$ & -8 & $26 ; 36$ & 33 & $15 ; 107$ & 73 & $\begin{array}{c}21112113221222142511 \\
25122531253225333111 \\
3113 \text { A314l } \mathrm{M} 3113\end{array}$ \\
\hline F. humilis & 126 & $1 ; 2837$ & 399 & $-21 ; 11$ & -6 & $18 ; 39$ & 31 & $5 ; 178$ & 91 & $\begin{array}{c}21122113211422112212 \\
22132214221523112312 \\
23202410251125122521 \\
25312533311131123113 \\
32123221 \mathrm{M} 2410 \mathrm{M} 2414 \\
\mathrm{M} 3112 \mathrm{M} 3113 \\
\end{array}$ \\
\hline F. modicella & 118 & $1 ; 2185$ & 358 & $-22 ;-1$ & -9 & $25 ; 37$ & 30 & $15 ; 127$ & 87 & $\begin{array}{c}21112112211321142212 \\
22132214221523202511 \\
25122521253125333111 \\
311331313134 \mathrm{M} 3112 \\
\mathrm{M} 3113 \\
\end{array}$ \\
\hline F. obrussa & 205 & $5 ; 2770$ & 678 & $-24 ; 8$ & -10 & $19 ; 37$ & 30 & $15 ; 142$ & 73 & $\begin{array}{c}21112112211321142212 \\
22132214221523122320 \\
25112512252325312532 \\
25333111311231133134 \\
\text { A3141 A3142 M2414 } \\
\text { M3112 M3113 M3120 } \\
\text { P3131 }\end{array}$ \\
\hline$F . p a r v a$ & 152 & $5 ; 3077$ & 884 & $-22 ;-1$ & -10 & $22 ; 36$ & 31 & $15 ; 127$ & 69 & $\begin{array}{c}21112113211422122213 \\
22142215232025112512 \\
25312533311131123113 \\
31313140 \mathrm{~A} 3141 \mathrm{~A} 3142 \\
\mathrm{M} 2112 \mathrm{M} 3112 \mathrm{M} 3113 \\
\mathrm{M} 3120 \mathrm{P} 3131\end{array}$ \\
\hline G. armifera & 640 & $3 ; 2026$ & 312 & $-23 ; 7$ & -5 & $26: 37$ & 32 & $25 ; 168$ & 96 & $\begin{array}{c}21112113211422112212 \\
22132214221523112312 \\
23202511251225212522 \\
2523253125322533311 \\
3112311332113212 \\
\text { M3113 P3132 }\end{array}$ \\
\hline G. contracta & 893 & $0 ; 1491$ & 226 & $-24 ; 16$ & -4 & $24 ; 38$ & 32 & $25 ; 168$ & 102 & $\begin{array}{c}21112112211321142211 \\
22122213221422152311 \\
23122320251125122521 \\
25222523253125322533 \\
3113321132124110 \\
\end{array}$ \\
\hline G. cristata & 139 & $1 ; 2026$ & 497 & $-10 ; 11$ & -2 & $24 ; 38$ & 34 & $15 ; 127$ & 74 & $\begin{array}{c}22142215232025112512 \\
25212522252325312533 \\
311332113212 \quad \mathrm{P} 3132\end{array}$ \\
\hline G. holzingeri & 224 & $11 ; 2131$ & 398 & $-24 ; 4$ & -9 & $24 ; 38$ & 32 & $25 ; 147$ & 78 & $\begin{array}{c}21112112211322122213 \\
22142215232025112512 \\
25212522253125322533 \\
311231133211 \mathrm{M} 3113 \\
\mathrm{P} 3132 \\
\end{array}$ \\
\hline
\end{tabular}


Appendix 7 Continued

\begin{tabular}{|c|c|c|c|c|c|c|c|c|c|c|}
\hline \multirow{2}{*}{ TAXA } & \multirow{2}{*}{$n$} & \multicolumn{2}{|c|}{$\operatorname{ELEVTN}(\mathrm{m})$} & \multicolumn{2}{|c|}{$\operatorname{MinT}\left({ }^{\circ} \mathrm{C}\right)$} & \multicolumn{2}{|c|}{$\operatorname{MaxT}\left({ }^{\circ} \mathrm{C}\right)$} & \multicolumn{2}{|c|}{ PRECIP $(\mathrm{cm})$} & \multirow{2}{*}{ VEGETATION } \\
\hline & & $\mathrm{R}$ & $\mathbf{M}$ & $\mathrm{R}$ & $\mathbf{M}$ & $\mathrm{R}$ & $\mathbf{M}$ & $\mathrm{R}$ & $\mathbf{M}$ & \\
\hline G. pellucida & 182 & $1 ; 2131$ & 469 & $-14 ; 16$ & 1 & $27 ; 41$ & 34 & $5 ; 168$ & 82 & $\begin{array}{c}2215231123122320 \\
2511251225212522 \\
2523253125333112 \\
3113314032113212 \\
32224110 \mathrm{M} 3113 \\
\text { M3120 P3131 P3132 }\end{array}$ \\
\hline G. pentodon & 684 & $1 ; 2405$ & 249 & $-24 ; 16$ & -4 & $21 ; 39$ & 31 & $5 ; 168$ & 103 & 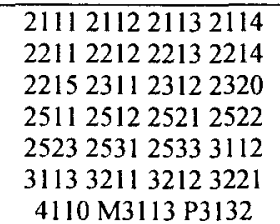 \\
\hline G. procera & 393 & $0 ; 2026$ & 342 & $-16 ; 11$ & -3 & $26 ; 38$ & 33 & $18 ; 168$ & 91 & $\begin{array}{c}2113221122122213 \\
2214221523112312 \\
2320251125122521 \\
2522252325312533 \\
3111311231133211 \\
3212 \text { P } 3132\end{array}$ \\
\hline G. riograndensis & 6 & $12 ; 1491$ & 623 & $-3 ; 11$ & 5 & $28 ; 37$ & 34 & $25 ; 66$ & 45 & 252332113212 \\
\hline G. rupicola & 71 & $0 ; 373$ & 38 & $-8 ; 16$ & 7 & $28 ; 34$ & 32 & $76 ; 168$ & 133 & $\begin{array}{c}2113221422152311 \\
2312232025112512 \\
25314110\end{array}$ \\
\hline G. tappaniana & 512 & $1 ; 1341$ & 225 & $-24 ; 14$ & -4 & $21 ; 37$ & 32 & $25 ; 168$ & 99 & 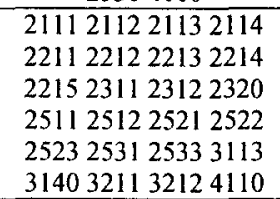 \\
\hline G. circumstriatus & 86 & $15 ; 3095$ & 999 & $-24 ; 8$ & -12 & $22 ; 39$ & 30 & $5 ; 112$ & 57 & $\begin{array}{c}2111211321142212 \\
2213221425112512 \\
2523253225333111 \\
311231133221 \mathrm{~A} 3141 \\
\text { A3142 M3112 M3113 } \\
\text { P3131 }\end{array}$ \\
\hline G. deflectus & 129 & $3 ; 2105$ & 256 & $-24 ; 3$ & -10 & $24 ; 36$ & 29 & $38 ; 127$ & 90 & $\begin{array}{c}2111211221132114 \\
2212221322142215 \\
2320251125312533 \\
3112 \mathrm{M} 3120 \\
\end{array}$ \\
\hline G. parvus & 366 & $1 ; 3095$ & 606 & $-31 ; 16$ & -10 & $8 ; 39$ & 30 & $5 ; 183$ & 74 & $\begin{array}{c}1210122021112112 \\
2113211422112212 \\
2213221422152311 \\
2312232025112512 \\
2521252225232531 \\
2532253331113112 \\
3113313132123221 \\
4110 \text { A3141 A3142 } \\
\text { M2410 M2620 M3112 } \\
\text { M3113 M3120 P3131 } \\
\text { P3132 } \\
\end{array}$ \\
\hline H. minuscula & 826 & $0 ; 2428$ & 296 & $-24 ; 23$ & -3 & $19 ; 41$ & 32 & $5 ; 348$ & 100 & $\begin{array}{c}2111211221132114 \\
2211221222132214 \\
2215231123122320 \\
2511251225212522 \\
2523253125333111 \\
3112311331343140 \\
3211321232213222 \\
4110 \mathrm{M} 2112 \mathrm{M} 2413 \\
\mathrm{M} 2414 \mathrm{M} 2620 \mathrm{M} 3112 \\
\mathrm{M} 3113 \mathrm{M} 3120 \mathrm{M} 4210 \\
\mathrm{P} 3131 \mathrm{P} 3132\end{array}$ \\
\hline
\end{tabular}


Appendix 7 Continued

\begin{tabular}{|c|c|c|c|c|c|c|c|c|c|c|}
\hline \multirow{2}{*}{ TAXA } & \multirow{2}{*}{$n$} & \multicolumn{2}{|c|}{ ELEVTN $(m)$} & \multicolumn{2}{|c|}{$\operatorname{Min} T\left({ }^{\circ} \mathrm{C}\right)$} & \multicolumn{2}{|c|}{$\operatorname{MaxT}\left({ }^{\circ} \mathrm{C}\right)$} & \multicolumn{2}{|c|}{ PRECIP $(\mathrm{cm})$} & VEGETATION \\
\hline & & & & & & & $\mathbf{M}$ & $\mathrm{R}$ & $\mathbf{M}$ & 2111211221132114 \\
\hline H. parallelus & 852 & $1 ; 1989$ & 237 & $-24 ; 13$ & -4 & $21 ; 38$ & 31 & $15 ; 168$ & 104 & $\begin{array}{c}2211221222132214 \\
2215231123122320 \\
2511251225212523 \\
2531253331123113 \\
32113212 \mathrm{M} 3113 \quad \mathrm{P} 3132\end{array}$ \\
\hline H. singleyanus & 175 & $2 ; 1960$ & 408 & $-16 ; 11$ & -3 & $24 ; 38$ & 33 & $15 ; 152$ & 82 & $\begin{array}{c}2211221222132214 \\
2215231223202511 \\
2512252125222523 \\
2531253331123113 \\
314032113212 \mathrm{M} 3113 \\
\text { P3132 }\end{array}$ \\
\hline L. fuscus & 104 & $1 ; 633$ & 185 & $-22 ; 6$ & -6 & $26 ; 34$ & 30 & $61 ; 168$ & 101 & $\begin{array}{l}2111211321142212 \\
2213221422152311 \\
231223202511\end{array}$ \\
\hline N. electrina & 375 & $2 ; 2770$ & 335 & $-24: 1$ & -9 & $21 ; 38$ & 29 & $15: 213$ & 90 & $\begin{array}{c}2111211221132114 \\
2211221222132214 \\
2215232024102511 \\
2512253125333112 \\
311331313211 \text { A3141 } \\
\text { A } 3142 \mathrm{M} 2413 \mathrm{M} 2415 \\
\text { M2610 M3111 M3112 } \\
\text { M3113 P3131 P3132 }\end{array}$ \\
\hline Physidae & 958 & $0 ; 3095$ & 483 & $-31: 23$ & -7 & $8 ; 39$ & 31 & $5 ; 348$ & 84 & $\begin{array}{c}1210122021112112 \\
2113211422112212 \\
2213221422152311 \\
2312232024102511 \\
2512252125222523 \\
2531253225333111 \\
3112311331313133 \\
3134314032113212 \\
322132224110 \mathrm{~A} 3141 \\
\mathrm{~A} 3142 \mathrm{M} 2111 \mathrm{M} 2112 \\
\mathrm{M} 2411 \mathrm{M} 2413 \mathrm{M} 2414 \\
\mathrm{M} 2415 \mathrm{M} 2620 \mathrm{M} 3111 \\
\mathrm{M} 3112 \mathrm{M} 3113 \mathrm{M} 3120 \\
\mathrm{M} 4210 \mathrm{P} 3131 \mathrm{P} 3132\end{array}$ \\
\hline Pisidiidae & 610 & $0 ; 3095$ & 488 & $-33 ; 16$ & -5 & $8: 39$ & 31 & $5 ; 274$ & 90 & $\begin{array}{c}1210122013202111 \\
2112211321142211 \\
2212221322142215 \\
2311231223202410 \\
2511251225212522 \\
2531253225332610 \\
3111311231133120 \\
3131313331403212 \\
32214110 \mathrm{~A} 3141 \mathrm{~A} 3142 \\
\mathrm{M} 1310 \mathrm{M} 2111 \mathrm{M} 2112 \\
\mathrm{M} 2410 \mathrm{M} 2411 \mathrm{M} 2413 \\
\mathrm{M} 2414 \mathrm{M} 2610 \mathrm{M} 2620 \\
\mathrm{M} 3112 \mathrm{M} 3113 \mathrm{M} 3120 \\
\mathrm{M} 4210 \mathrm{P} 3131\end{array}$ \\
\hline P. trivolvis & 492 & $1 ; 2956$ & 414 & $-33 ; 16$ & -8 & $21 ; 39$ & 31 & $5: 157$ & 83 & $\begin{array}{c}1320211121122113 \\
2114221122122213 \\
2214221523112312 \\
2320241025112512 \\
2521252325312532 \\
2533311231133131 \\
3134321232214110 \\
\text { A3141 A3142 M3112 } \\
\text { M } 3113 \mathrm{M} 3120\end{array}$ \\
\hline
\end{tabular}


Appendix 7 Continued

\begin{tabular}{|c|c|c|c|c|c|c|c|c|c|c|}
\hline \multirow{2}{*}{ TAXA } & \multirow{2}{*}{$\mathrm{n}$} & \multicolumn{2}{|c|}{ ELEVTN $(m)$} & \multicolumn{2}{|c|}{$\operatorname{MinT}\left({ }^{\circ} \mathrm{C}\right)$} & \multicolumn{2}{|c|}{$\operatorname{MaxT}\left({ }^{\circ} \mathrm{C}\right)$} & \multicolumn{2}{|c|}{ PRECIP $(\mathrm{cm})$} & \multirow{2}{*}{ VEGETATION } \\
\hline & & $\mathrm{R}$ & $\mathbf{M}$ & $\mathrm{R}$ & $\mathbf{M}$ & $\mathrm{R}$ & $\mathbf{M}$ & $\mathrm{R}$ & $\mathbf{M}$ & \\
\hline P. armigera & 131 & $1 ; 582$ & 226 & $-24: 11$ & -10 & $25 ; 36$ & 29 & $43 ; 127$ & 88 & $\begin{array}{c}2111211221132114 \\
2212221322142215 \\
2312232025112512 \\
2522252325312532 \\
2533\end{array}$ \\
\hline P. exacuous & 157 & $5 ; 2610$ & 410 & $-24 ;-1$ & -12 & $25 ; 36$ & 29 & $25 ; 127$ & 80 & $\begin{array}{l}2111211221132114 \\
2212221322142215 \\
2320251125312532 \\
2533311231133131 \\
\mathrm{~A} 3142 \mathrm{M} 3112 \mathrm{M} 3113 \\
\end{array}$ \\
\hline P. minutissimum & 480 & $2 ; 2610$ & 315 & $-24 ; 11$ & -5 & $21 ; 37$ & 30 & $25 ; 168$ & 100 & $\begin{array}{c}2111211221132114 \\
2211221222132214 \\
2215231123122320 \\
2511251225222523 \\
2531253331113112 \\
3113313132113212 \\
\text { A3142 M2412 M2414 } \\
\text { M2620 M3112 M3113 } \\
\text { M3120 P3131 P3132 }\end{array}$ \\
\hline P. blandi & 81 & $259 ; 3095$ & 1691 & $-22 ;-1$ & -11 & $22 ; 38$ & 30 & $15 ; 96$ & 40 & $\begin{array}{c}2511251225333111 \\
3112311331313133 \\
3134314032113212 \\
\text { A3141 A3142 M3112 } \\
\text { M3113 M3120 P3131 } \\
\text { P3132 }\end{array}$ \\
\hline P. muscorum & 103 & $2 ; 3095$ & 786 & $-23 ; 1$ & -10 & $22 ; 37$ & 29 & $15 ; 127$ & 72 & $\begin{array}{c}2111211321142212 \\
2213221422152320 \\
2511253225333111 \\
3112311331403211 \\
\text { A3141 M3112 M3113 } \\
\text { P3131 P3132 }\end{array}$ \\
\hline P. albilabris & 677 & $-12 ; 2026$ & 296 & $-16 ; 12$ & -3 & $24 ; 42$ & 32 & $5: 168$ & 99 & $\begin{array}{c}2113211422112212 \\
2213221422152311 \\
2312232025112512 \\
2521252225232531 \\
2533311231133140 \\
321132123222 \mathrm{M} 3113 \\
\text { P3131 P3132 }\end{array}$ \\
\hline P. modicus & 22 & 2,248 & 31 & $-6 ; 16$ & 10 & $31 ; 34$ & 33 & $96 ; 162$ & 133 & 221223114110 \\
\hline S. elodes & 173 & $13 ; 3095$ & 710 & $-23 ;-2$ & -13 & $22 ; 36$ & 29 & $15 ; 142$ & 68 & $\begin{array}{c}21112112 \quad 21132114 \\
2212221322142312 \\
2511253125323112 \\
3113 \text { A3142 M2610 } \\
\text { M3112 M3113 P3131 }\end{array}$ \\
\hline S. exilis & 28 & $180 ; 502$ & 302 & $-24 ;-7$ & -14 & $26: 32$ & 29 & $53 ; 96$ & 76 & $\begin{array}{c}2111211322122213 \\
25112531\end{array}$ \\
\hline S. idahoensis & 2 & $1179 ; 1213$ & 1196 & $-14 ;-12$ & -13 & $28 ; 28$ & 28 & $61 ; 63$ & 62 & M2112 M3111 \\
\hline S. labyrinthicus & 612 & $1 ; 1232$ & 226 & $-24 ; 16$ & -5 & $21 ; 37$ & 31 & $28 ; 168$ & 102 & $\begin{array}{c}2111211221132114 \\
2211221222132214 \\
2215231123122320 \\
2511251225232531 \\
2533311231133212 \\
4110 \\
\end{array}$ \\
\hline
\end{tabular}


Appendix 7 Continued

\begin{tabular}{|c|c|c|c|c|c|c|c|c|c|c|}
\hline \multirow{2}{*}{ TAXA } & \multirow{2}{*}{$n$} & \multicolumn{2}{|c|}{$\operatorname{ELEVTN}(\mathrm{m})$} & \multicolumn{2}{|c|}{$\operatorname{MinT}\left({ }^{\circ} \mathrm{C}\right)$} & \multicolumn{2}{|c|}{$\operatorname{MaxT}\left({ }^{\circ} \mathrm{C}\right)$} & \multicolumn{2}{|c|}{ PRECIP $(\mathrm{cm})$} & \multirow{2}{*}{ VEGETATION } \\
\hline & & $\mathrm{R}$ & $\mathbf{M}$ & $\mathrm{R}$ & $\mathbf{M}$ & $\mathrm{R}$ & $\mathbf{M}$ & $\mathrm{R}$ & M & \\
\hline Succineidae & 1296 & $0 ; 3095$ & 339 & $-31 ; 23$ & -5 & $8 ; 41$ & 31 & $5 ; 348$ & 95 & $\begin{array}{c}1210122021112112 \\
2113211422112212 \\
2213221422152311 \\
2312232024102511 \\
2512252125222523 \\
2531253225332610 \\
3111311231133131 \\
3134314032113212 \\
322132224110 \mathrm{~A} 3141 \\
\mathrm{~A} 3142 \mathrm{M} 1310 \mathrm{M} 2112 \\
\mathrm{M} 2410 \mathrm{M} 2412 \mathrm{M} 2414 \\
\mathrm{M} 2610 \mathrm{M} 2620 \mathrm{M} 3112 \\
\mathrm{M} 3113 \mathrm{M} 3120 \mathrm{M} 4210 \\
\mathrm{P} 3131 \mathrm{P} 3132\end{array}$ \\
\hline V. cyclophorella & 76 & $76 ; 3077$ & 1591 & $-22 ; 3$ & -10 & $23: 39$ & 30 & $5 ; 84$ & 38 & $\begin{array}{c}2213261031123113 \\
3120313131333134 \\
3140321132213222 \\
\text { A3141 M2112 M2415 } \\
\text { M2610 M2620 M3112 } \\
\text { M3113 M3120 P3131 } \\
\text { P3132 }\end{array}$ \\
\hline$V$. gracilicosta & 114 & $10 ; 2637$ & 1015 & $-24 ;-1$ & -11 & $24: 38$ & 31 & $15 ; 112$ & 49 & $\begin{array}{c}2111211221132114 \\
2213221425112512 \\
2521253125322533 \\
3111311231133131 \\
3211 \mathrm{~A} 3141 \mathrm{M} 2610 \\
\mathrm{M} 3112 \mathrm{M} 3113 \mathrm{P} 3131 \\
\text { P3132 } \\
\end{array}$ \\
\hline V. parvula & 165 & 122,2026 & 462 & $-22 ; 4$ & -7 & $26 ; 37$ & 33 & $28 ; 127$ & 75 & $\begin{array}{c}2111211322122213 \\
2214221523202511 \\
2512252125222531 \\
2533311231133211 \\
3212 \text { P3132 }\end{array}$ \\
\hline V. perspectiva & 97 & $2 ; 2146$ & 656 & $-23 ; 3$ & -9 & $27 ; 38$ & 31 & $15 ; 147$ & 68 & $\begin{array}{c}2111211322112213 \\
2214221523202511 \\
2521253125323112 \\
3113314032113212 \\
3222 \mathrm{M} 3120 \mathrm{P} 3131 \\
\text { P3132 } \\
\end{array}$ \\
\hline V. pulchella & 343 & $1 ; 2837$ & 354 & $-24 ; 9$ & -8 & $21: 39$ & 30 & $5 ; 183$ & 86 & $\begin{array}{c}2111211221132114 \\
2211221222132214 \\
2215232025112512 \\
2531261031113112 \\
3113313432113212 \\
3221 \mathrm{~A} 3141 \mathrm{M} 2414 \\
\mathrm{M} 2610 \mathrm{M} 2620 \mathrm{M} 3112 \\
\text { M } 3113 \mathrm{P} 3132\end{array}$ \\
\hline V. tricarinata & 154 & $5: 1410$ & 296 & $-24 ; 3$ & -12 & $25 ; 36$ & 29 & $33 ; 137$ & 80 & $\begin{array}{c}2111211221132114 \\
2212221322142215 \\
2311231223202511 \\
2531253225333112 \\
3113 \mathrm{M} 3112 \\
\end{array}$ \\
\hline$V$. elatior & 122 & $6 ; 2058$ & 365 & $-24 ;-3$ & -12 & $24 ; 37$ & 29 & $15 ; 122$ & 78 & $\begin{array}{c}2111211221132114 \\
2211221222132214 \\
2511253125323112 \\
3211 \mathrm{M} 3112 \mathrm{M} 3113 \\
\text { P3132 }\end{array}$ \\
\hline$V$. milium & 384 & $1 ; 2341$ & 204 & $-23 ; 16$ & -3 & $23 ; 37$ & 32 & $28 ; 165$ & 105 & $\begin{array}{c}2111211321142211 \\
2212221322142215 \\
2311231223202511 \\
2512252225232531 \\
2533311231133140 \\
32124110 \mathrm{M} 3113\end{array}$ \\
\hline
\end{tabular}


Appendix 7 Continued

\begin{tabular}{|c|c|c|c|c|c|c|c|c|c|c|}
\hline \multirow{2}{*}{ TAXA } & \multirow{2}{*}{$\mathrm{n}$} & \multicolumn{2}{|c|}{$\operatorname{ELEVTN}(\mathbf{m})$} & \multicolumn{2}{|c|}{$\operatorname{MinT}\left({ }^{\circ} \mathrm{C}\right)$} & \multicolumn{2}{|c|}{$\operatorname{MaxT}\left({ }^{\circ} \mathrm{C}\right)$} & \multicolumn{2}{|c|}{ PRECIP $(\mathrm{cm})$} & \multirow{2}{*}{ VEGETATION } \\
\hline & & $\mathrm{R}$ & $\mathbf{M}$ & $\mathrm{R}$ & $\mathbf{M}$ & $\mathrm{R}$ & $\mathbf{M}$ & $\mathrm{R}$ & $\mathbf{M}$ & \\
\hline V. ovata & 467 & $1 ; 3095$ & 286 & $-24 ; 16$ & -5 & $18 ; 39$ & 31 & $5 ; 178$ & 97 & $\begin{array}{c}2111211221132114 \\
2211221222132214 \\
2215231123122320 \\
2511251225212522 \\
2523253125322533 \\
3113313331403211 \\
321232214110 \mathrm{M} 2410 \\
\mathrm{M} 2610 \mathrm{M} 3113 \mathrm{P} 3131 \\
\text { P3132 } \\
\end{array}$ \\
\hline$V \cdot$ rugosula & 76 & $1: 551$ & 125 & $-11 ; 9$ & 2 & $28 ; 36$ & 34 & $61 ; 168$ & 124 & $\begin{array}{c}2113221122152311 \\
2312232025112512 \\
25222533\end{array}$ \\
\hline Z. arboreus & 1527 & $0 ; 3095$ & 331 & $-24 ; 23$ & -4 & $19 ; 41$ & 31 & $5 ; 348$ & 100 & $\begin{array}{c}21111211221132114 \\
2211221222132214 \\
2215231123122320 \\
2410251125122521 \\
2522252325312532 \\
2533261031113112 \\
3113312031313134 \\
3140321132123221 \\
32224110 \mathrm{~A} 3141 \mathrm{~A} 3142 \\
\text { M2111 M2112 M2411 } \\
\text { M2412 M2413 M2414 } \\
\text { M2415 M2610 M2620 } \\
\text { M3111 M3112 M3113 } \\
\text { M3120 M4210 P3131 } \\
\text { P3132 }\end{array}$ \\
\hline All Counties & 3142 & $-12 ; 3095$ & 387 & $-33 ; 23$ & -5 & $8: 43$ & 31 & $5 ; 355$ & 93 & See Appendix 1 \\
\hline
\end{tabular}




\section{Appendix 7 Continued}
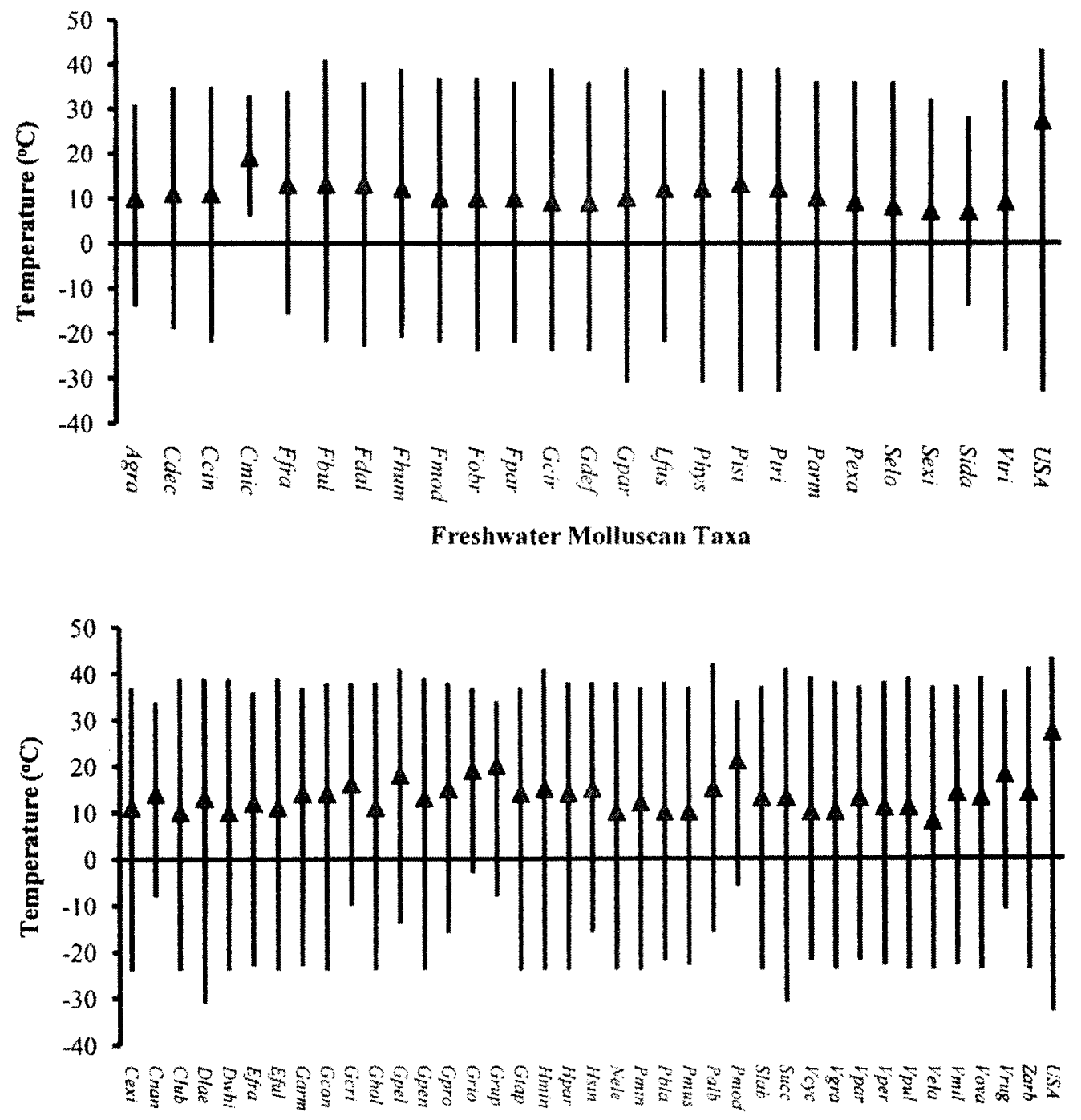

Land Molluscan Taxa

Appendix 7b. Temperature Ranges and Means. Graphs of temperature ranges and means for the freshwater (above) and land (below) molluscan taxa examined in this study. The ranges display the most minimum, minimum temperature and most maximum, maximum temperature, as well as the mean temperature calculated from all relevant temperature data in the Climate Database for each taxon. "All Counties" displays similar data for the entire United States for comparison. Species names were abbreviated by reducing the genus name to its first letter and reducing the specific name to its first three letters $($ Fdal $=$ Fossaria dalli $)$. Family names were abbreviated to the first four letters. All Counties was abbreviated as USA. 


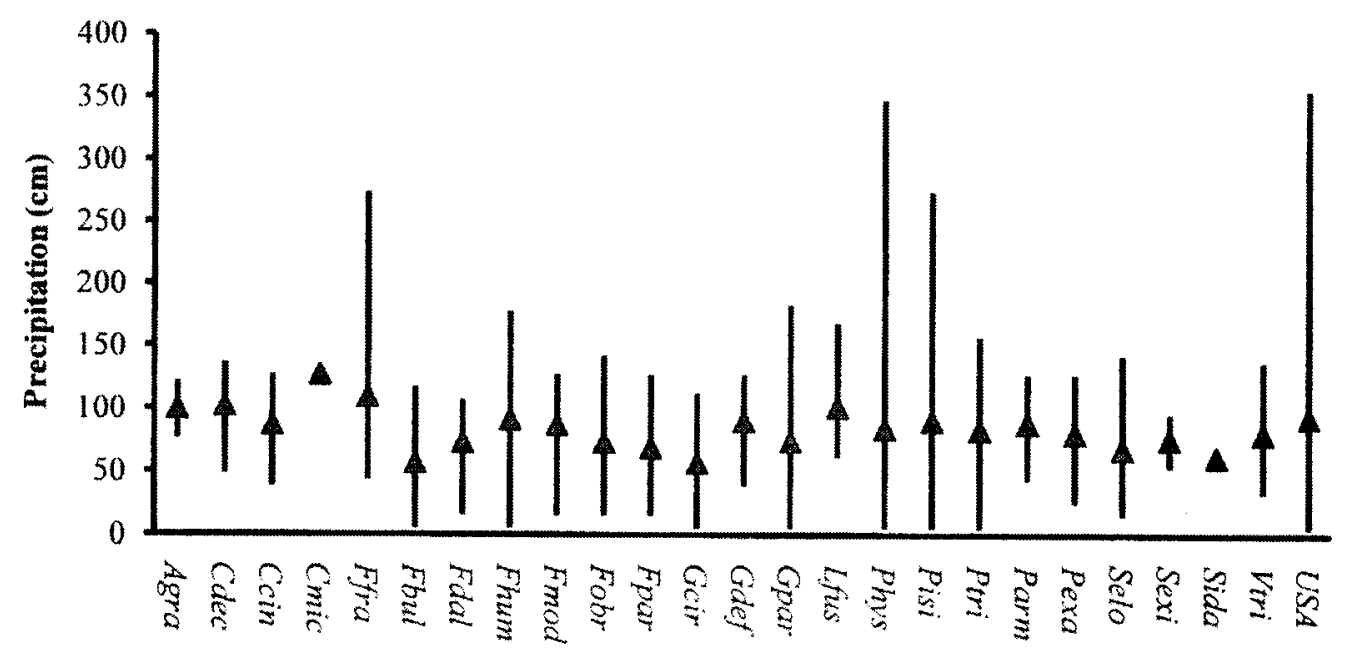

Freshwater Mollusean Taxa

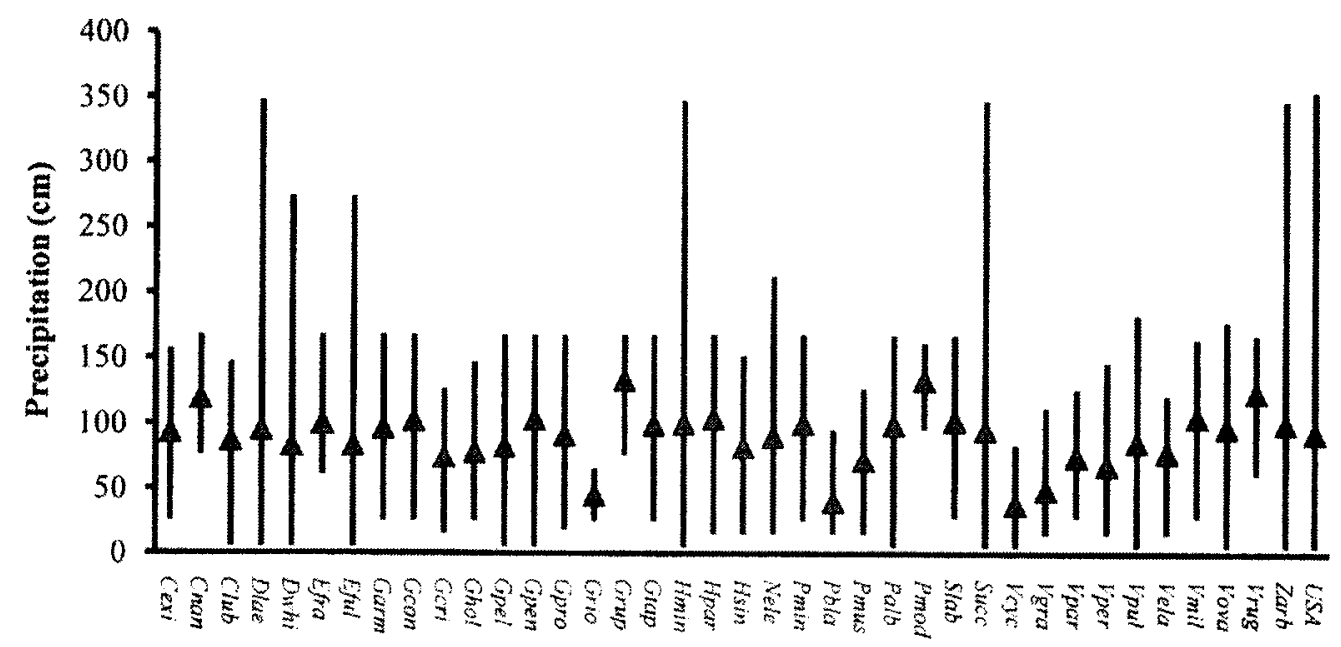

Land Molluscan Taxa

Appendix 7c. Precipitation Ranges and Means. Graphs of precipitation ranges and means for the freshwater (above) and land (below) molluscan taxa examined in this study. The ranges display the most minimum precipitation and most maximum precipitation, as well as the mean precipitation calculated from all relevant precipitation data in the Climate Database for each taxon. "All Counties" displays similar data for the entire United States for comparison. Species names were abbreviated by reducing the genus name to its first letter and reducing the specific name to its first three letters $(F d a l=$ Fossaria dalli). Family names were abbreviated to the first four letters. All Counties was abbreviated as USA. 
Appendix 8

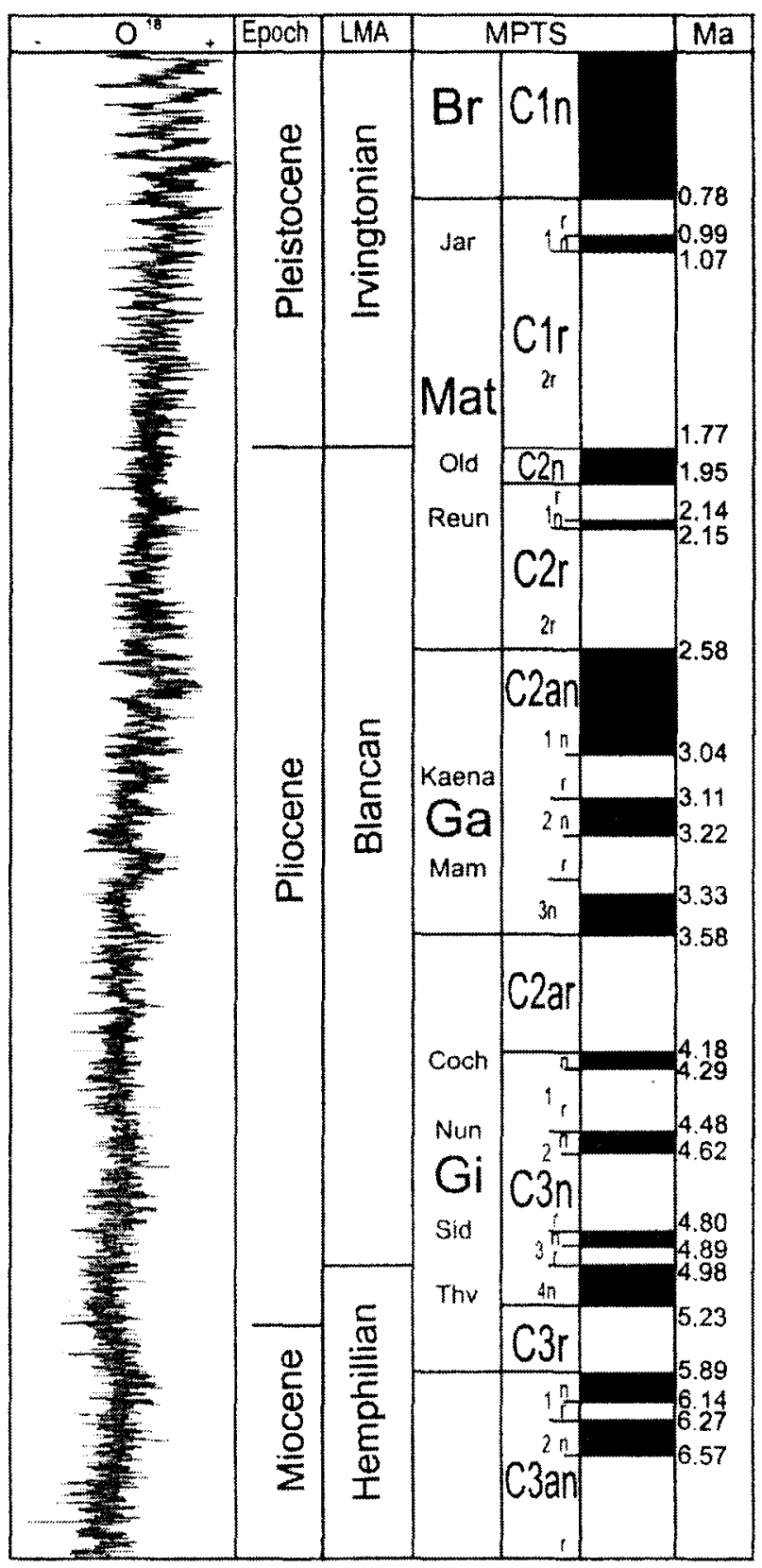

Oxygen isotopes. Oxygen isotope ratio data and magnetic reversal timescale for the late Cenozoic era (modified from Marcolini and Martin [2008], Fig. 1). The oxygen values reflect the ratio of oxygen-16 to oxygen- 18 isotopes in the calcite skeletons of benthic marine foraminifera. Positive trends in $\delta^{18} \mathrm{O}$ values indicate cooling of the deep sea, while negative trends in $\delta^{18} \mathrm{O}$ values indicate a warming of the sea. In the figure above, there is an overall cooling trend as the $\delta^{18} \mathrm{O}$ ratios become positive, but with many abrupt fluctuations. 


\section{GLOSSARY OF SELECTED TERMS}

Below are several terms which are used in this study and require clarification. The definitions are my own, except where indicated by italics.

Available - When used in the taxonomic sense (and only then), it indicates a name which was presumably constructed in accordance with the rules or customs of zoological nomenclature in effect at the time of a paper's publication date. Currently, to be available, a name must be constructed according to Article 1.3 and Articles 10 through 20 of the $4^{\text {th }}$ edition of the International Code of Zoological Nomenclature (ICZN, 1999).

Climate/paleoclimate - In this study climate refers to the ranges and means of temperature and precipitation of the United States and/or the ranges and means of temperature and precipitation experienced by the molluscan taxa examined in this study. Included in this definition are two climate related variables: elevation and vegetation. All climate and related data were collected at the county level so the term climate is regarded herein as synonymous with the term "macroclimate." "Microclimate," as might be experienced by gastropods as the difference in temperature/moisture under leaf litter or on a blade of grass in full sun a few meters away, was not addressed in this study. Paleoclimate is just the estimation of temperature and precipitation conditions (macroclimate) assumed to have existed when fossils were alive.

Extinction - The death of the last living member of a species (Bogan, 2006): "global extinction." Extirpation - The death of a local population of a more broadly distributed species (Bogan, 2006): "local extinction."

Ma - A unit of time. Million years, the "a" stands for annum (year) (Harland et al., 1990; Ogg et al., 2008) and the " $M$ " is the metric prefix for mega $\left(10^{6}\right)$ (Harland et al., 1990). This unit represents an instant in time (a numerical date), as opposed to a temporal range, and was determined via radiometric (isotopic) dating techniques. Absolute dating requires numeric dates.

Molluscan assemblage - Assemblages are equivalent to local faunas, described by Taylor (1960) as a suite 
of fossils found at a single stratigraphic location. The fossils within a local fauna are temporally equivalent and from a limited geographic area. An assemblage is comprised of the fossils which remained after a sample was washed and picked. A molluscan assemblage is equivalent to both a molluscan taxocene, an assemblage of taxonomically related organisms (Hutchinson, 1978), and a molluscan taphocoenosis, a taphonomically altered accumulation of dead shells (Martin, 1999). Assemblages are examined and interpreted similarly to living communities studied by ecologists and take their names from the samples from which they were derived. The term assemblage is used herein as a synonym for the term community, as would be used in ecology.

Molluscan fossil - An empty shell generated by the death and decay of the mollusc's soft anatomy. Fossils are Pleistocene or earlier in age (approximately $0.01 \mathrm{Ma}$ or older). Empty shells from the Holocene ( 0.01 Ma through the present day) were regarded as "modern," "recent," "extant" or "living" rather than as fossils. It is noted that not all researchers use this definition for fossils.

Paleoecology - That subdiscipline of paleontology which applies ecological principles and techniques to fossils.

Publication/literature - These two terms are used synonymously. With respect to the construction of the Molluscan Biogeography Database, the terms refer to articles published in scientific journals, scholarly books, surveys conducted on the behalf of government or other organizations, pamphlets privately printed by their authors, etc. Elsewhere in this study these terms are used in a more restricted sense to refer to journal articles published in scientific journals or scholarly books.

Sample - A volume of sediment and the fossils contained within it, removed from an outcrop for analysis. Samples are analogous in principle to dredged lake-bottom samples or leaf litter samples collected by an ecologist, but differ in that the samples used herein were more extensively time averaged-composed of multiple shells from multiple cohorts/historical ages, mixed and altered by biogeochemical processes (Fürsich and Aberhan, 1990) over geologically long time periods.

Taphonomy - the study of the formation of fossil deposits. This involves everything from the death of an organism to its collection by a paleontologist. Taphonomic processes which shape fossil deposits include disarticulation of the body by biotic/abiotic agents, transportation/removal/deposition of body parts by bioticlabiotic agents, fragmentation of body parts via breakage or erosion by biotic/abiotic agents, burial 
of body parts in sediments, chemical alteration/dissolution of body parts and mixing of body parts from different historical periods via bioturbation (time-averaging) (Martin, 1999). Taphonomic processes are thus responsible for the accumulation of fossils and the destruction of fossils depending on which processes are operating and how they operate. 


\section{CLIMATE AND BIOGEOGRAPHIC PLATES}

The following pages display the biogeographic range maps produced for each extant molluscan taxon in this study, using the data recorded in the MBD as well as maps of various climate and climaterelated variables recorded in the $\mathrm{CD}$. Each taxon has a biogeographic range map for the contiguous states and some taxa have range maps for Alaska and/or Hawaii as well. If a map for Alaska or Hawaii is not displayed for a given taxon, then that taxon does not occur in those states (as best as can be determined from the literature used to compile the MBD, given the procedures in the Methods section). Molluscan biogeographic ranges as displayed in these maps are tentative and likely depict the minimum ranges within the United States. The climate and climate-related variables (elevation, mean minimum temperature for January, mean maximum temperature for July and mean annual precipitation) are displayed on maps of the contiguous states, Alaska and Hawaii.

The names of the counties on the maps can be determined by consulting USGS (2006), Rand Mc.Nally (2009a, b, c) or any good travel atlas or state map. Note: the boundaries of coastal counties do not stop at the water's edge but extend into the water for some distance. This gives coastal counties a shape which is different from what is expected from the shape of the coast. 


\section{ELEVATION BY COUNTY \\ FOR THE CONTIGUOUS STATES}

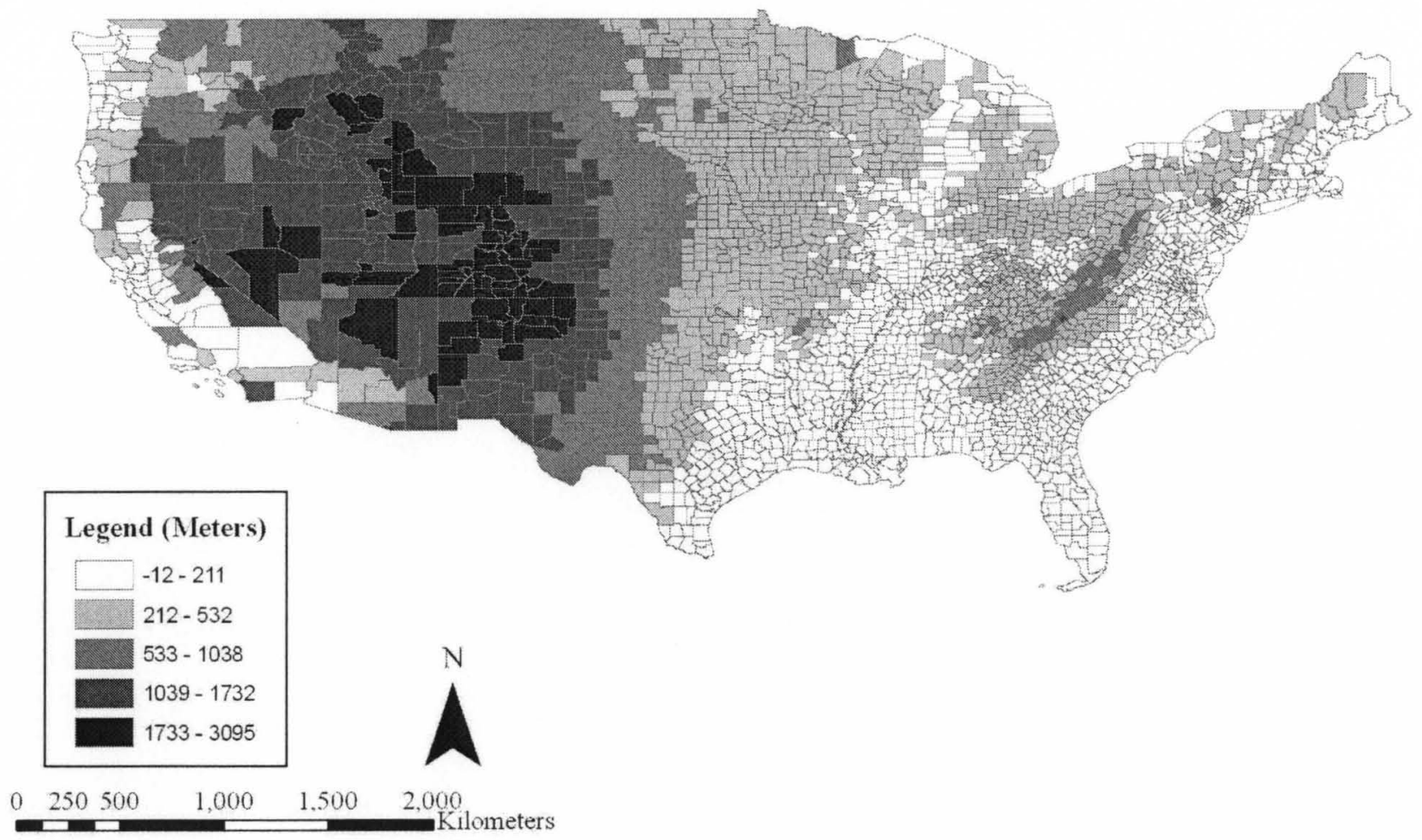




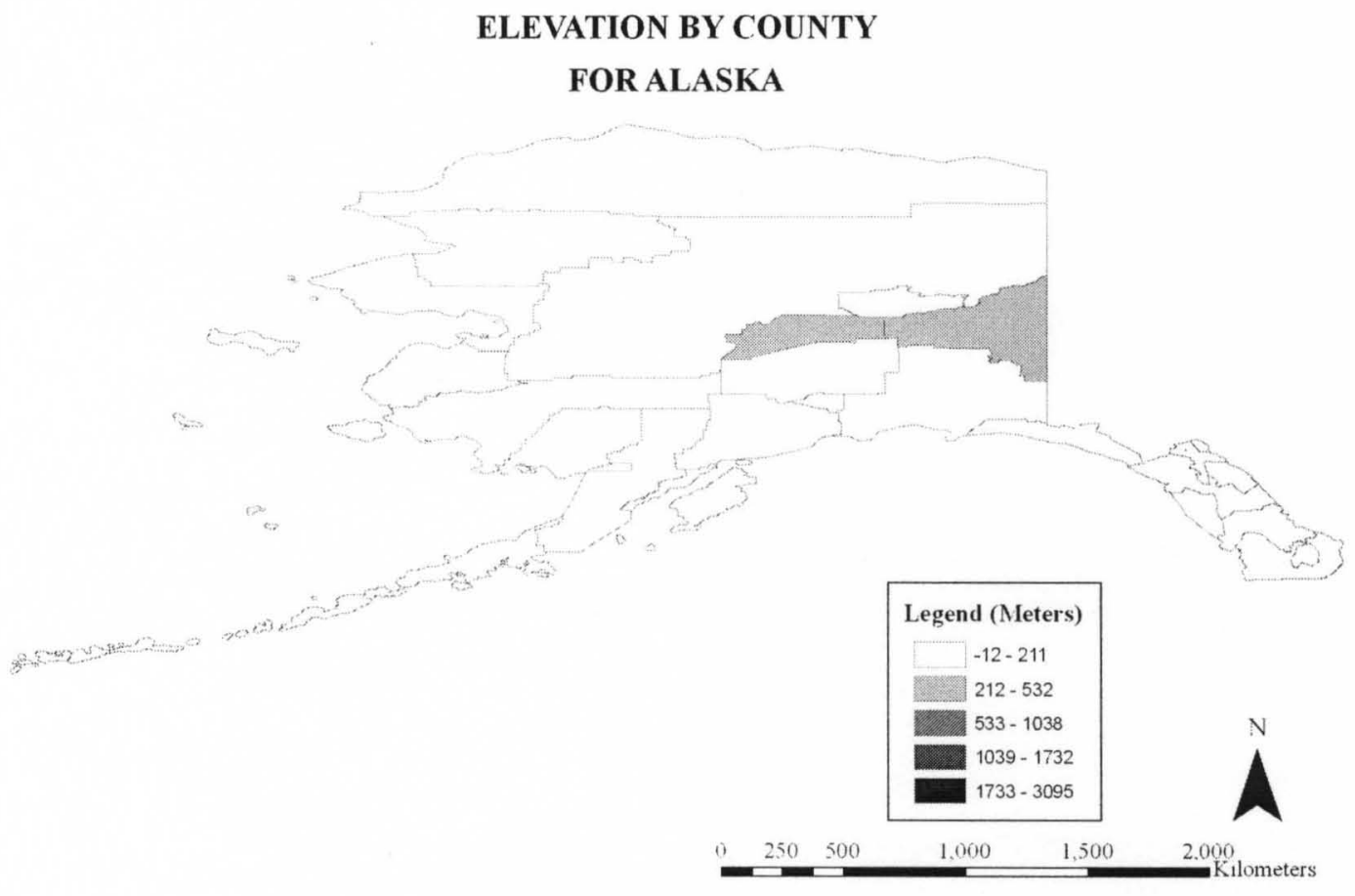

ELEVATION BY COUNTY

FOR HAWAII

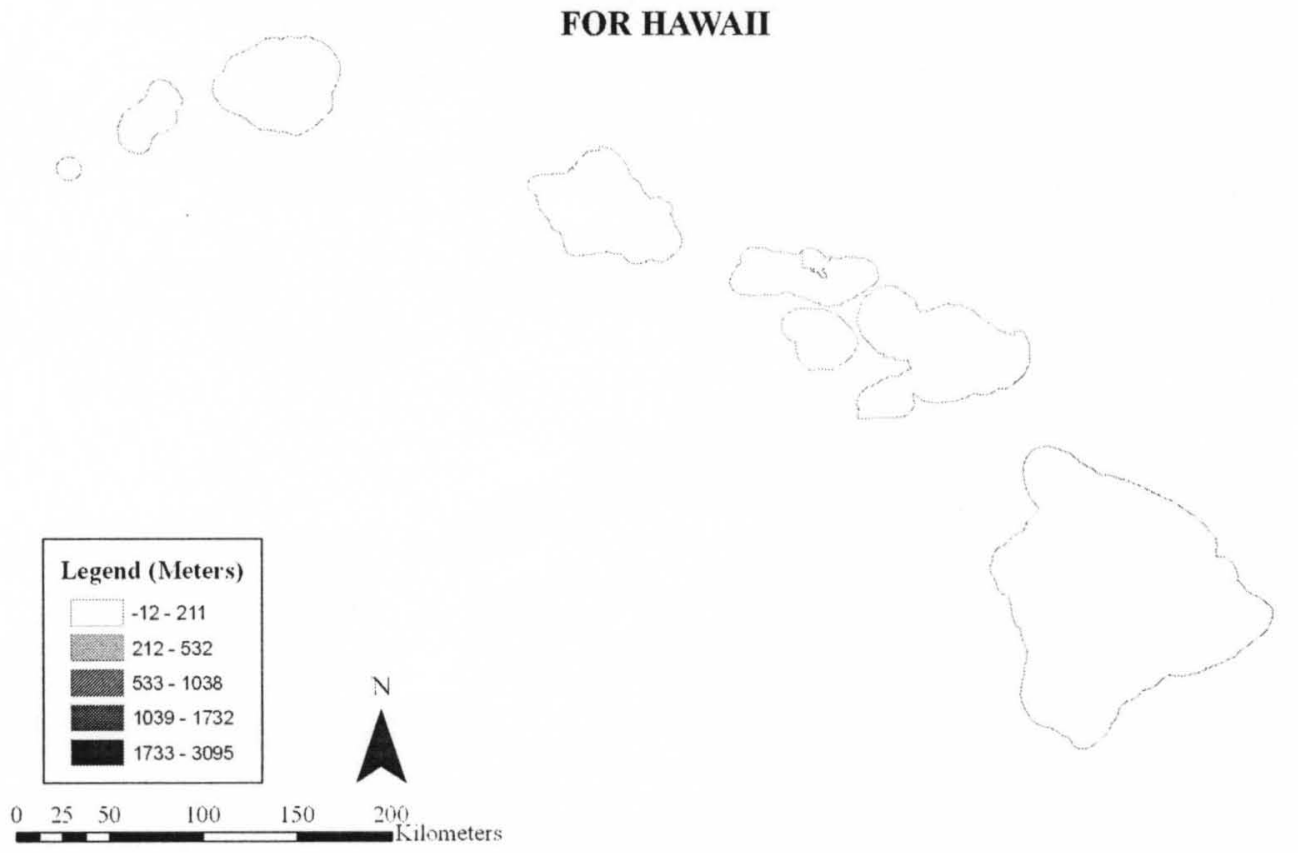




\section{MEAN MINIMUM TEMPERATURE FOR JANUARY BY COUNTY}

FOR THE CONTIGUOUS STATES

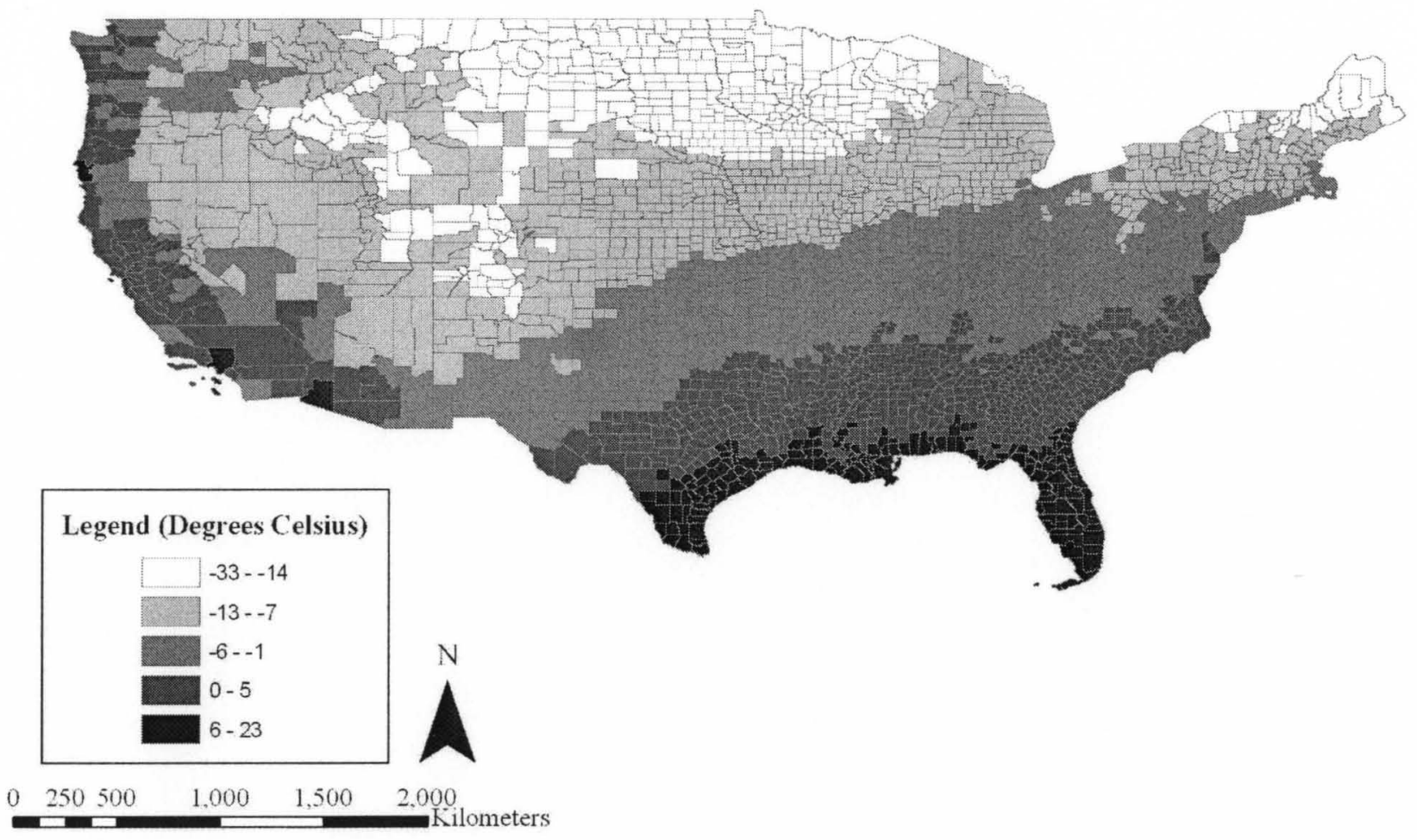




\section{MEAN MINIMUM TEMPERATURE FOR JANUARY BY COUNTY \\ FOR ALASKA}
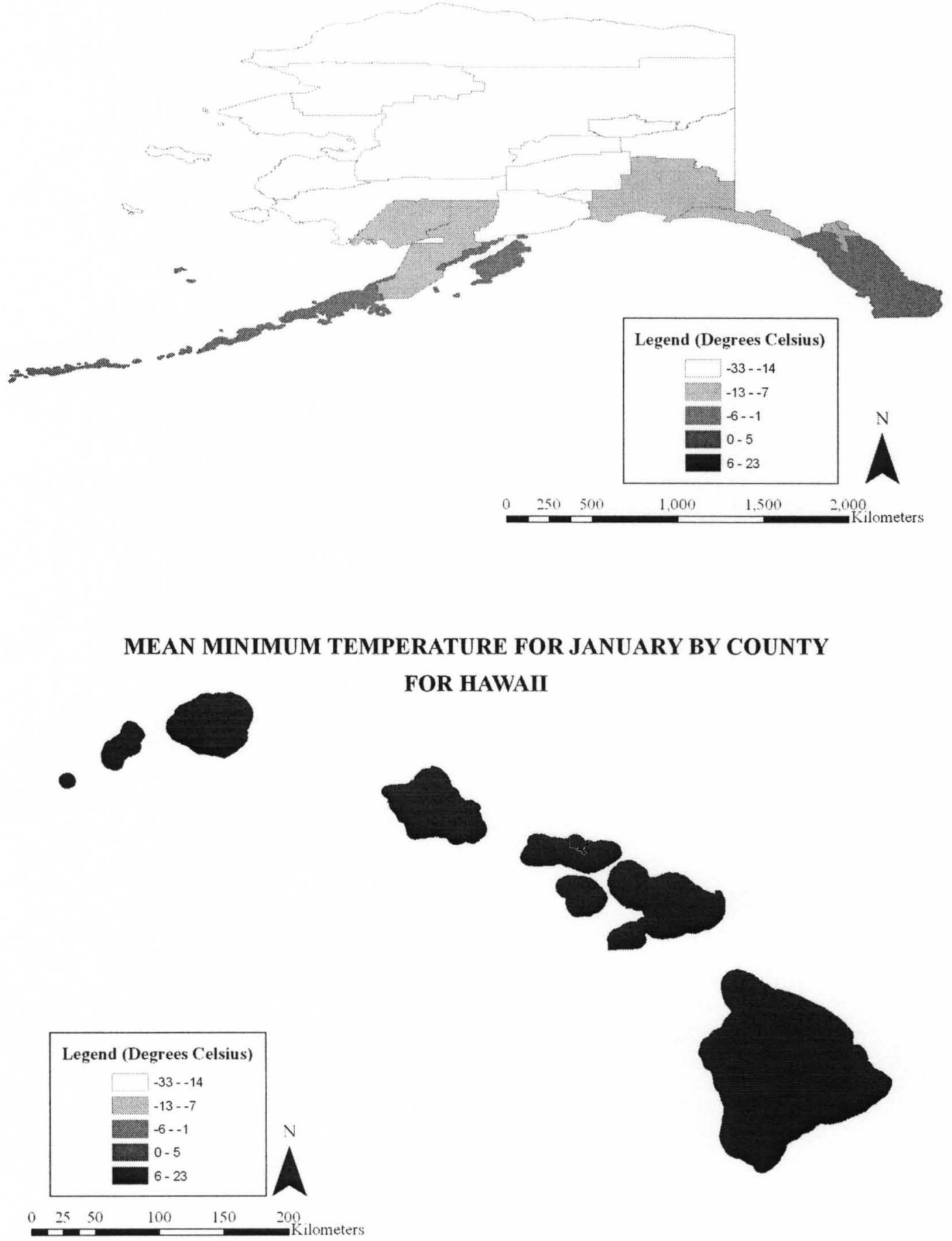
MEAN MAXIMUM TEMPERATURE FOR JULY BY COUNTY FOR THE CONTIGUOUS STATES

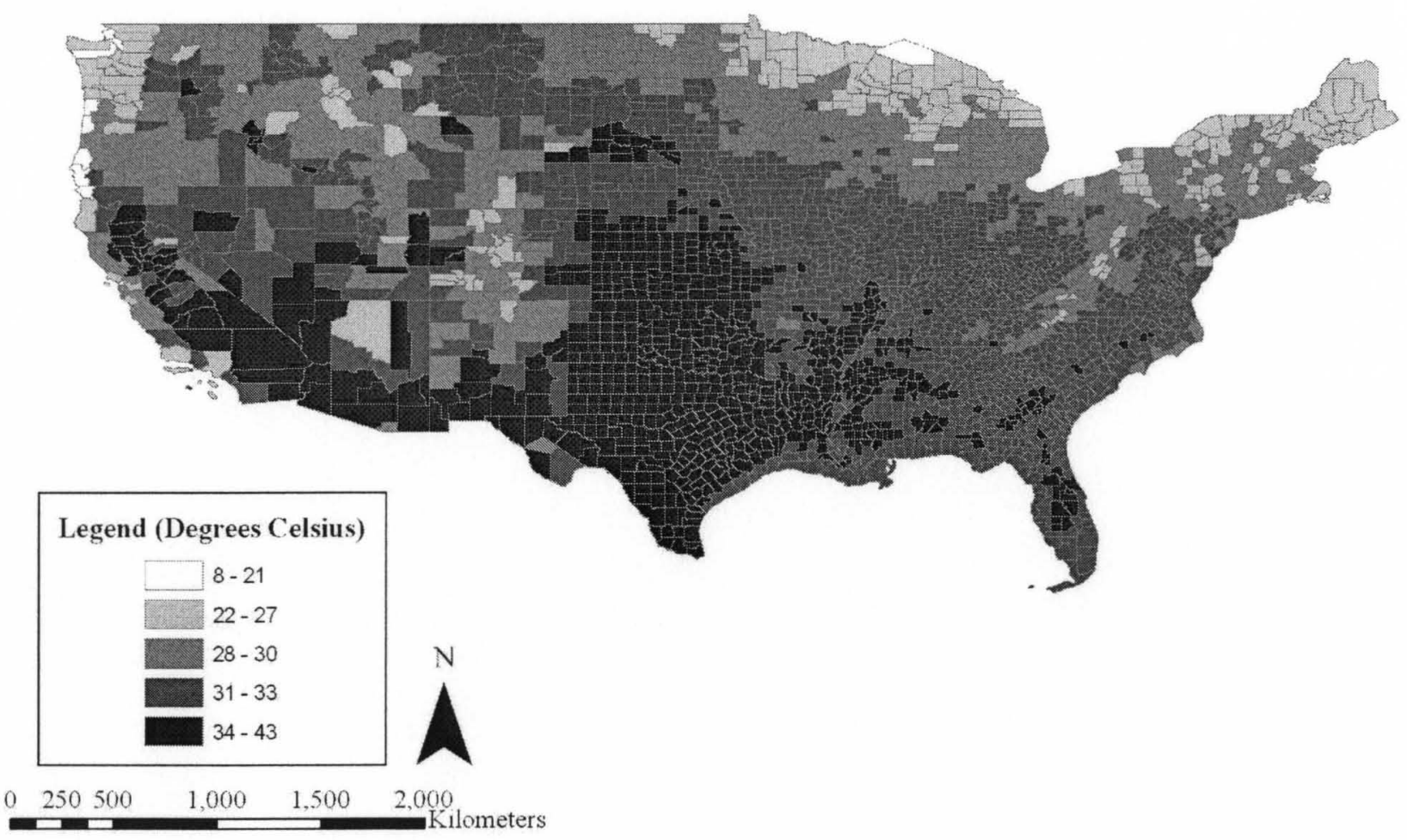




\section{MEAN MAXIMUM TEMPERATURE FOR JULY BY COUNTY}

FOR ALASKA

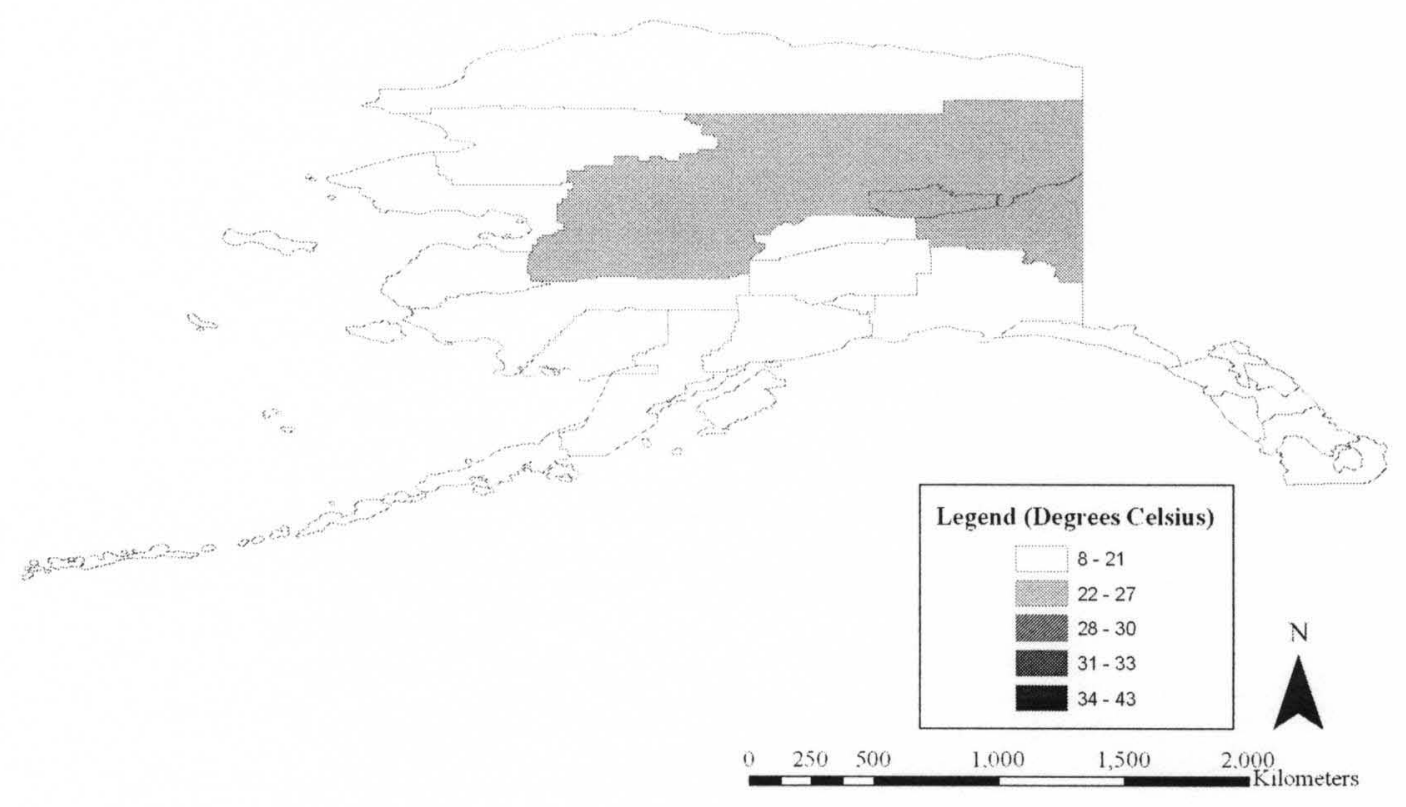

MEAN MAXIMUM TEMPERATURE FOR JULY BY COUNTY FOR HAWAII

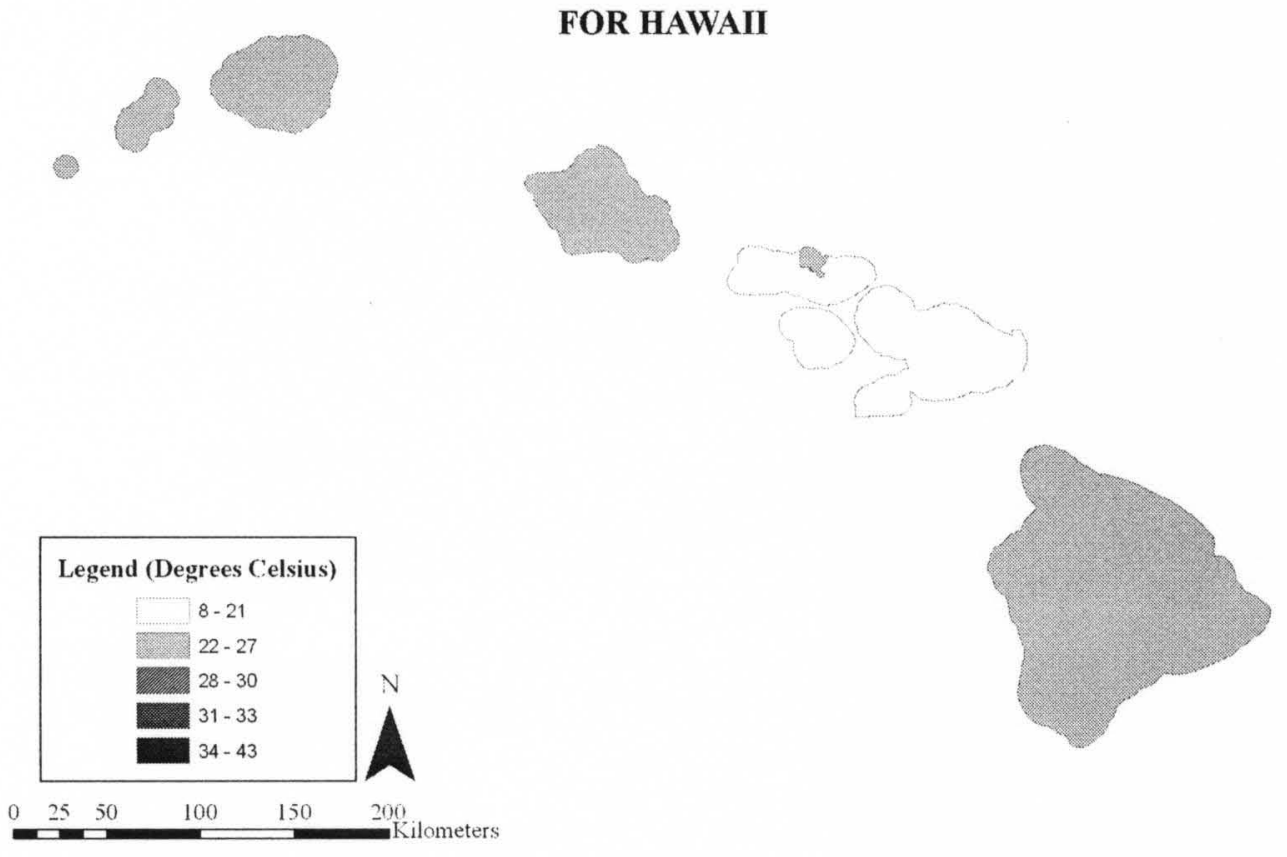


MEAN ANNUAL PRECIPITATION BY COUNTY FOR THE CONTIGUOUS STATES

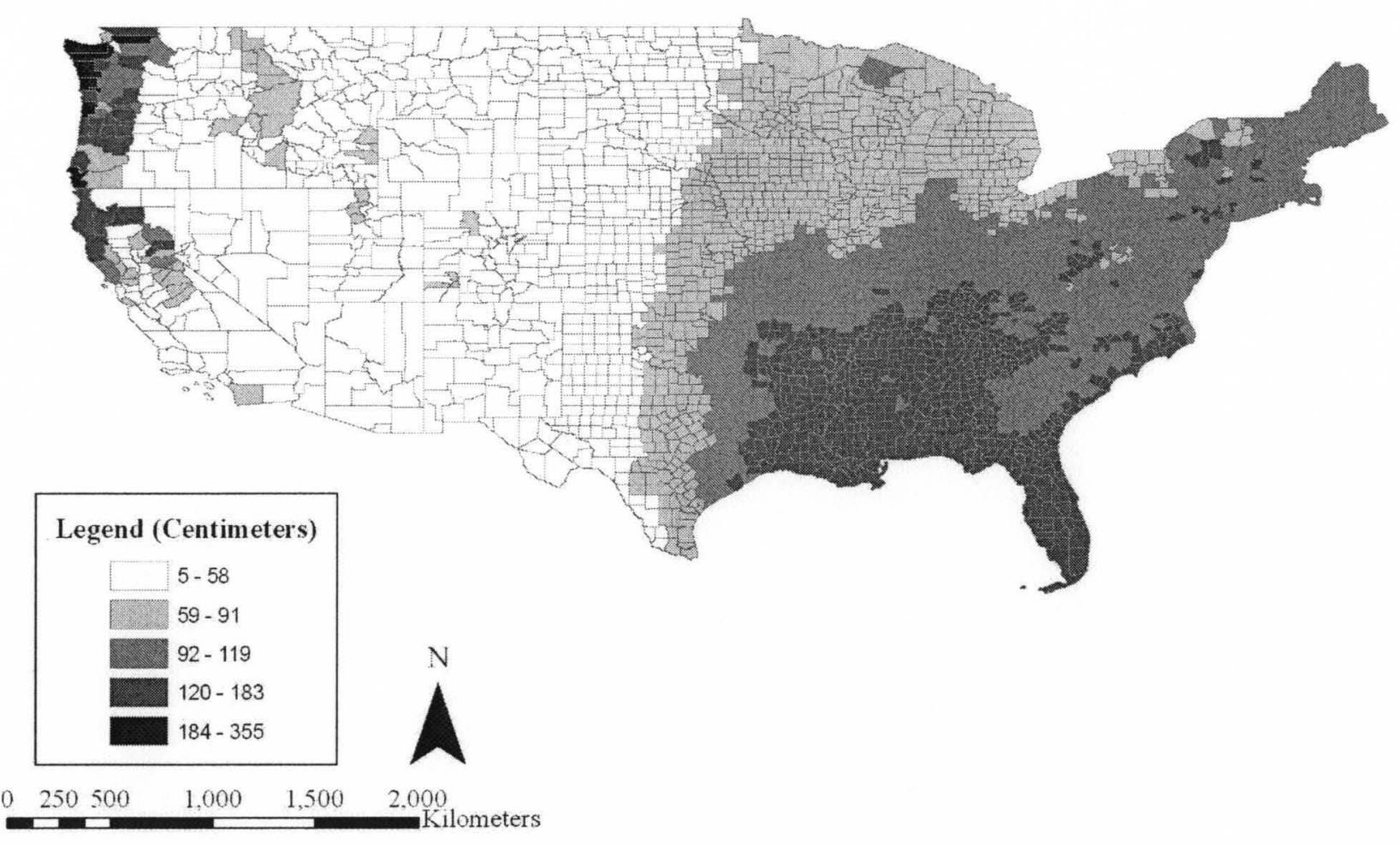



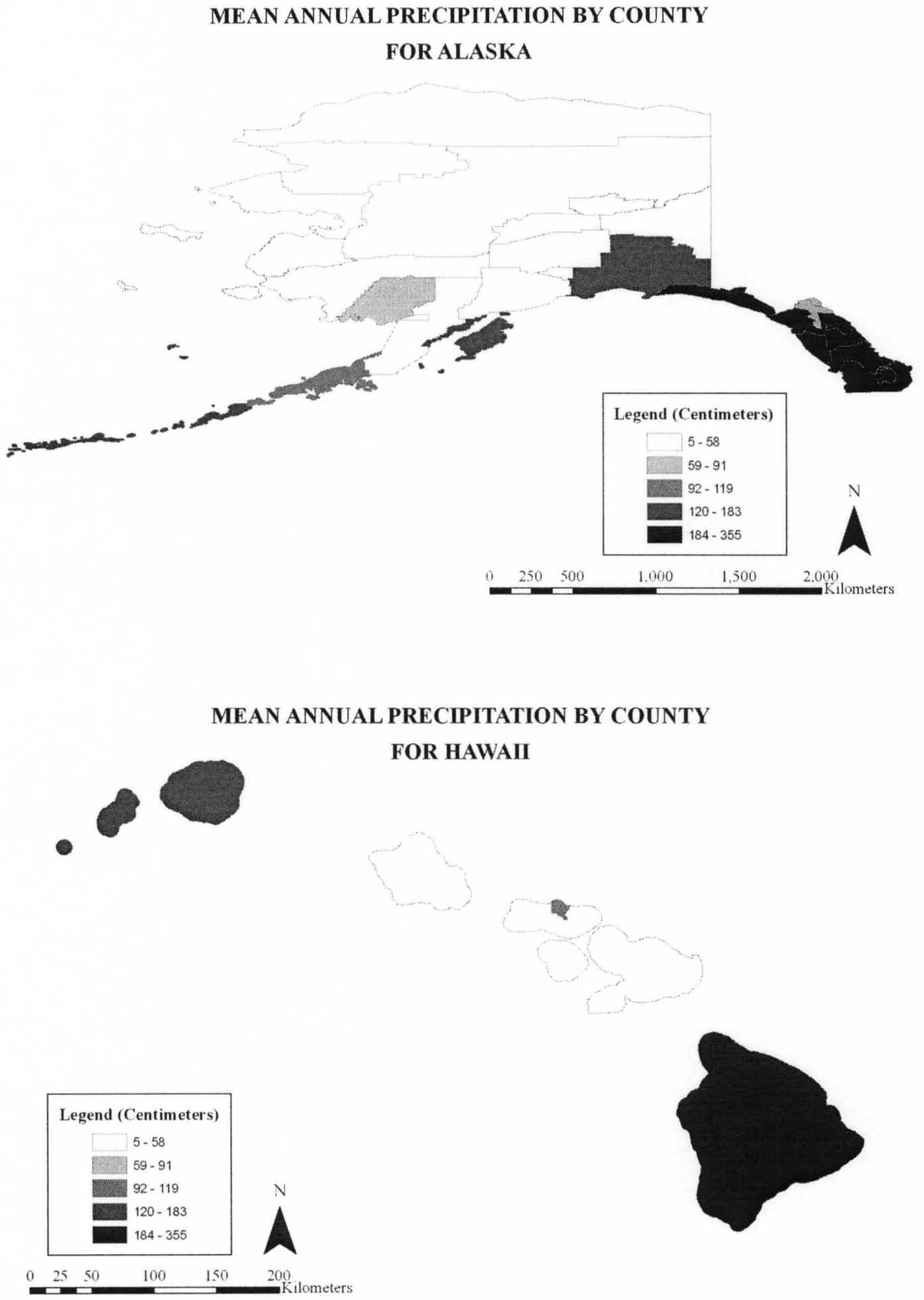


\section{BIOGEOGRAPHIC RANGE BY COUNTY IN THE CONTIGUOUS STATES}

Amnicola granum

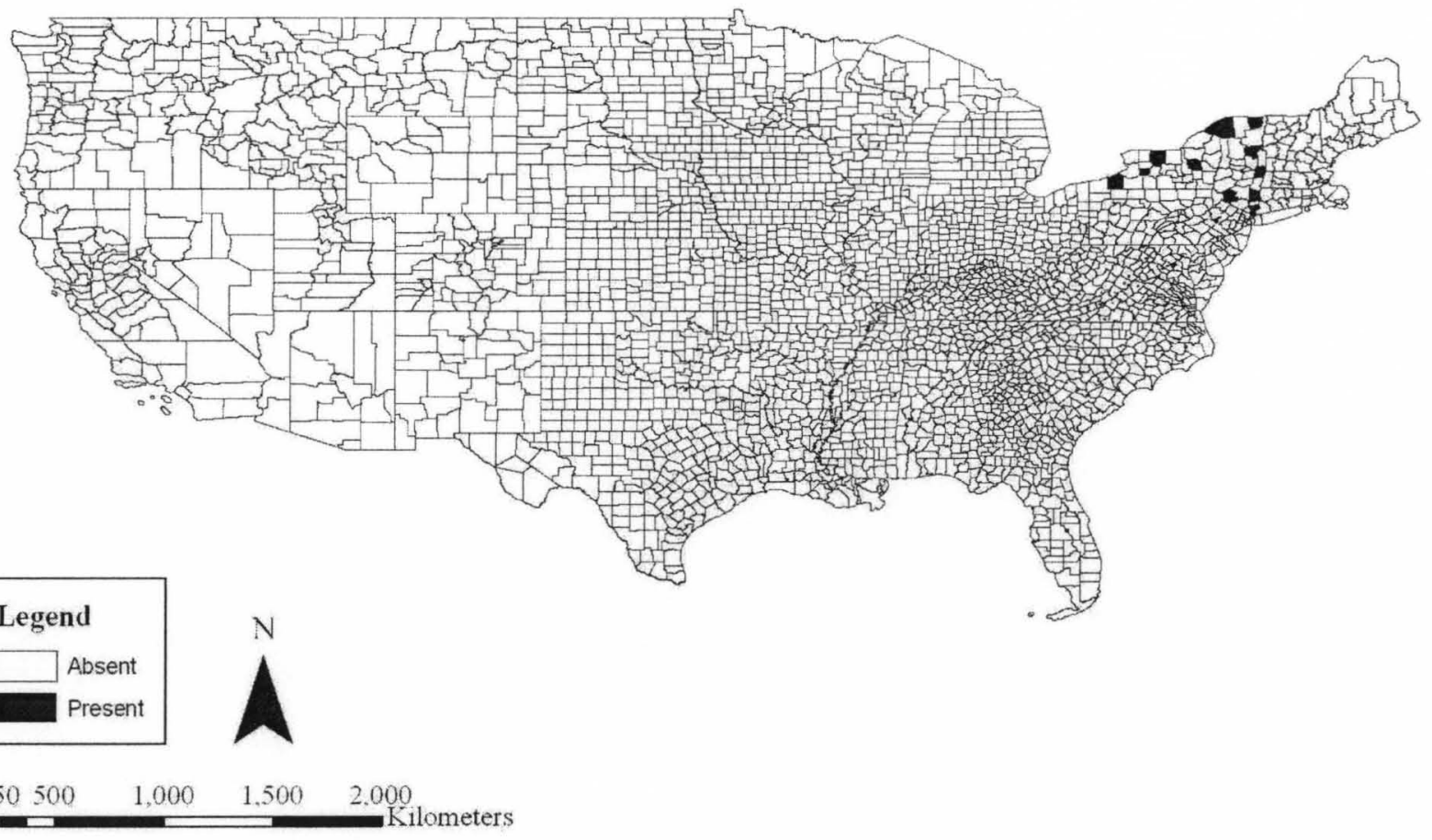


BIOGEOGRAPHIC RANGE BY COUNTY IN THE CONTIGUOUS STATES

Campeloma decisum

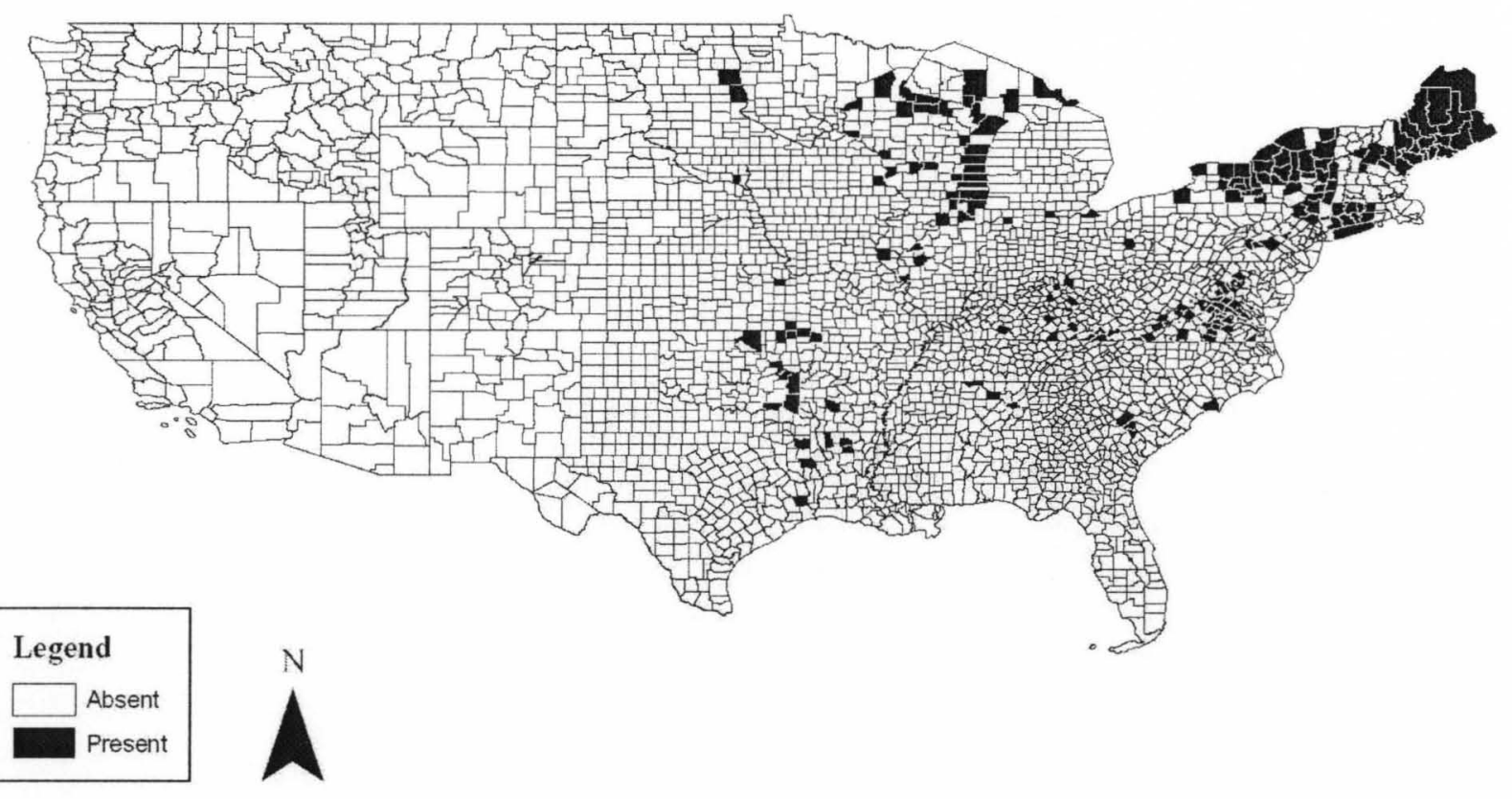

250500

1,000

Kilometers 


\section{BIOGEOGRAPHIC RANGE BY COUNTY IN THE CONTIGUOUS STATES}

Carychium exiguum

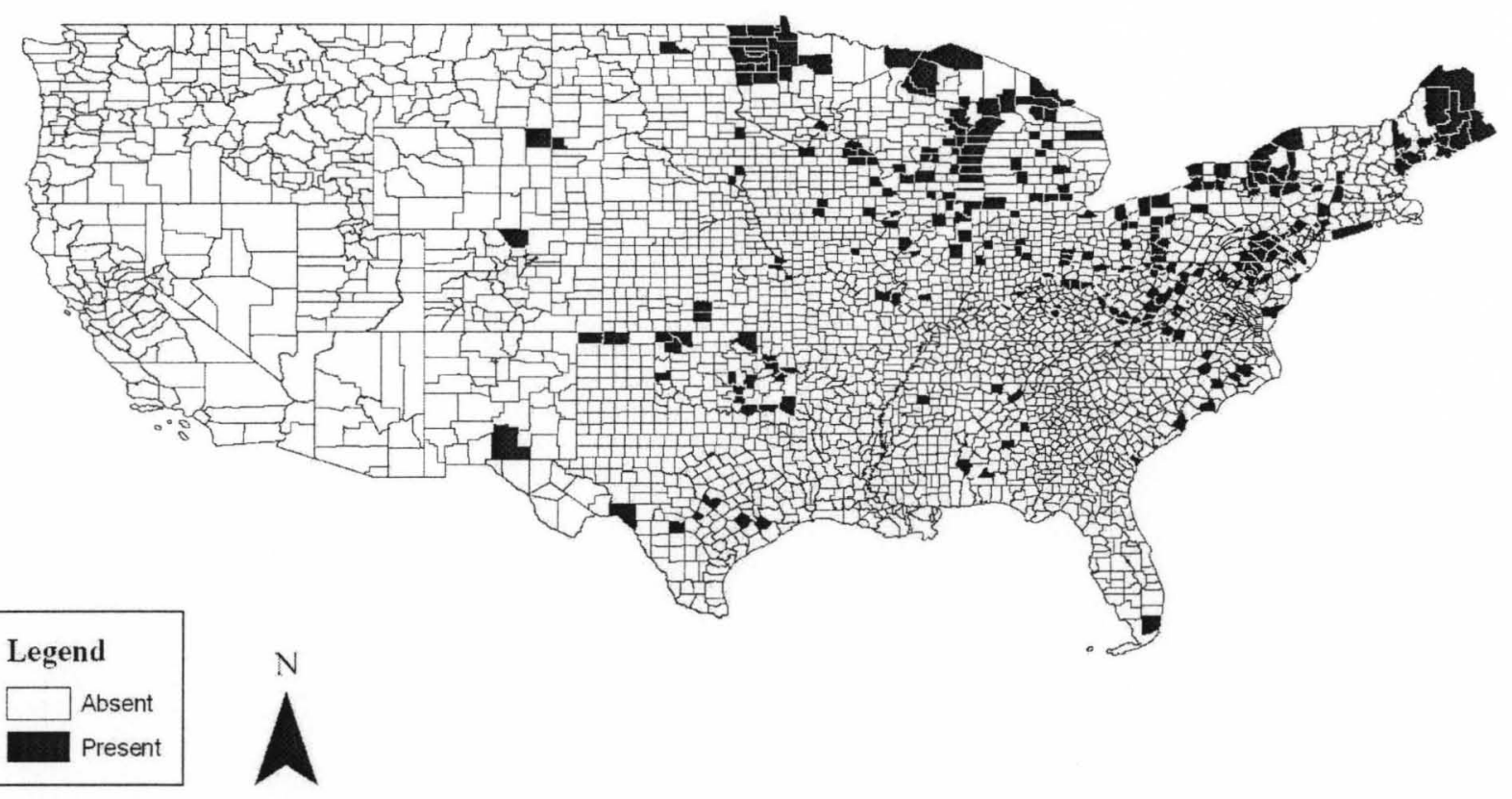

0 250500

$1,000 \quad 1,500$

Kilometers 


\section{BIOGEOGRAPHIC RANGE BY COUNTY IN THE CONTIGUOUS STATES}

Carychium nannodes

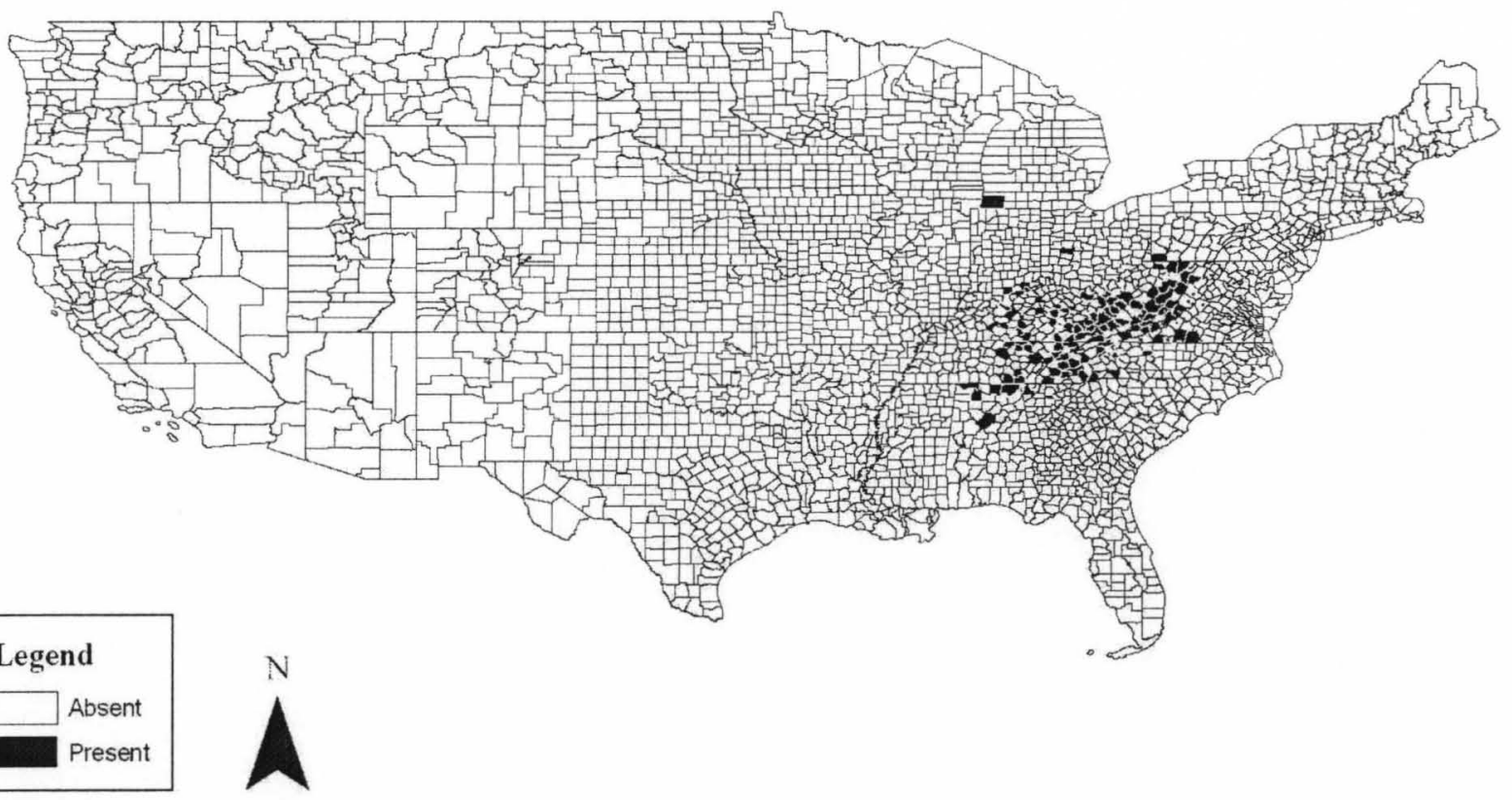

250500

1,000

, 500

$\begin{array}{llll}250500 \quad 1,000 & 1,500 \quad 2,000 \\ \mathbf{Z} & \text { Kilometers }\end{array}$ 


\section{BIOGEOGRAPHIC RANGE BY COUNTY IN THE CONTIGUOUS STATES}

Cincinnatia cincinnatiensis

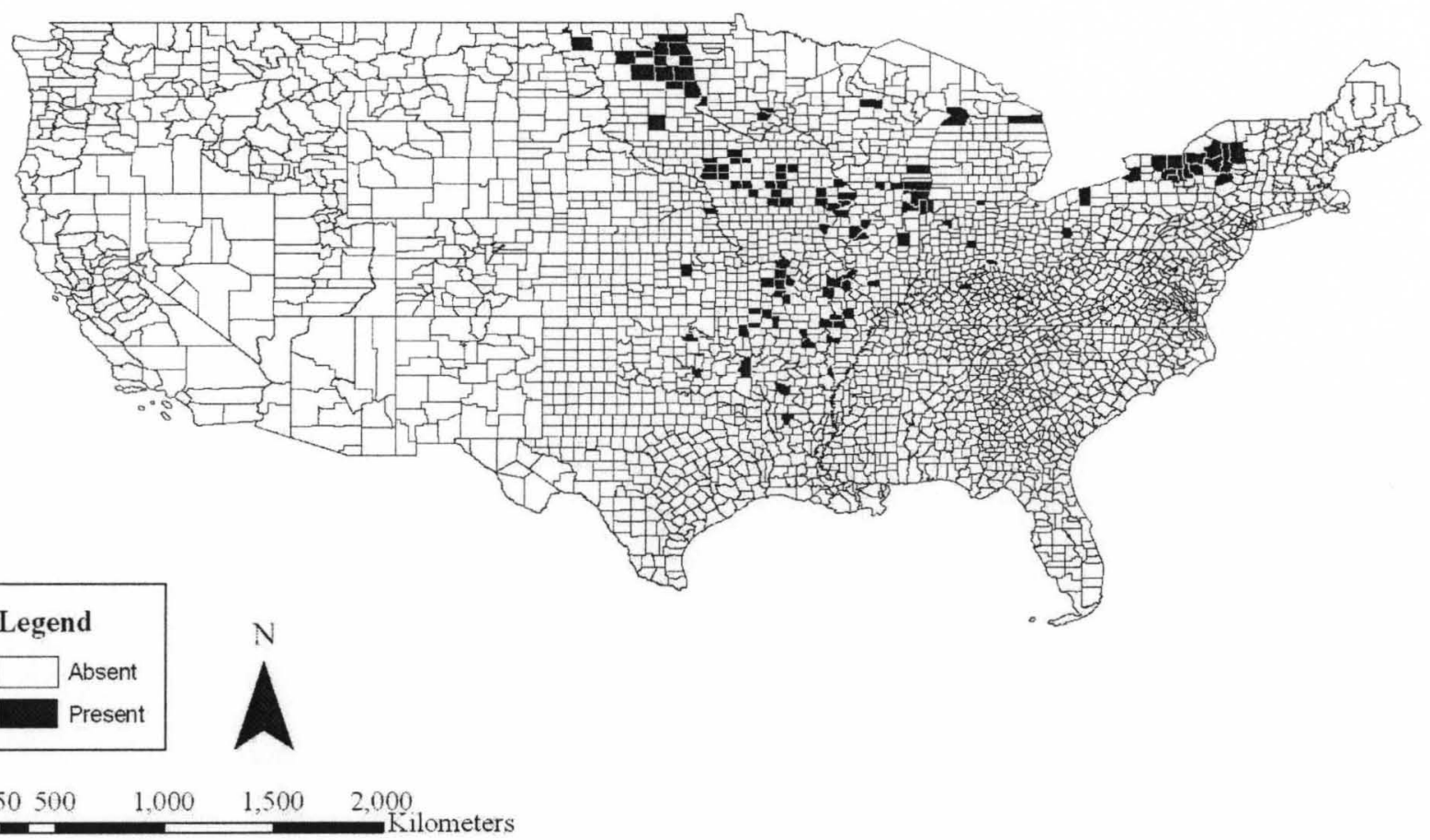




\section{BIOGEOGRAPHIC RANGE BY COUNTY IN THE CONTIGUOUS STATES}

Cincinnatia mica

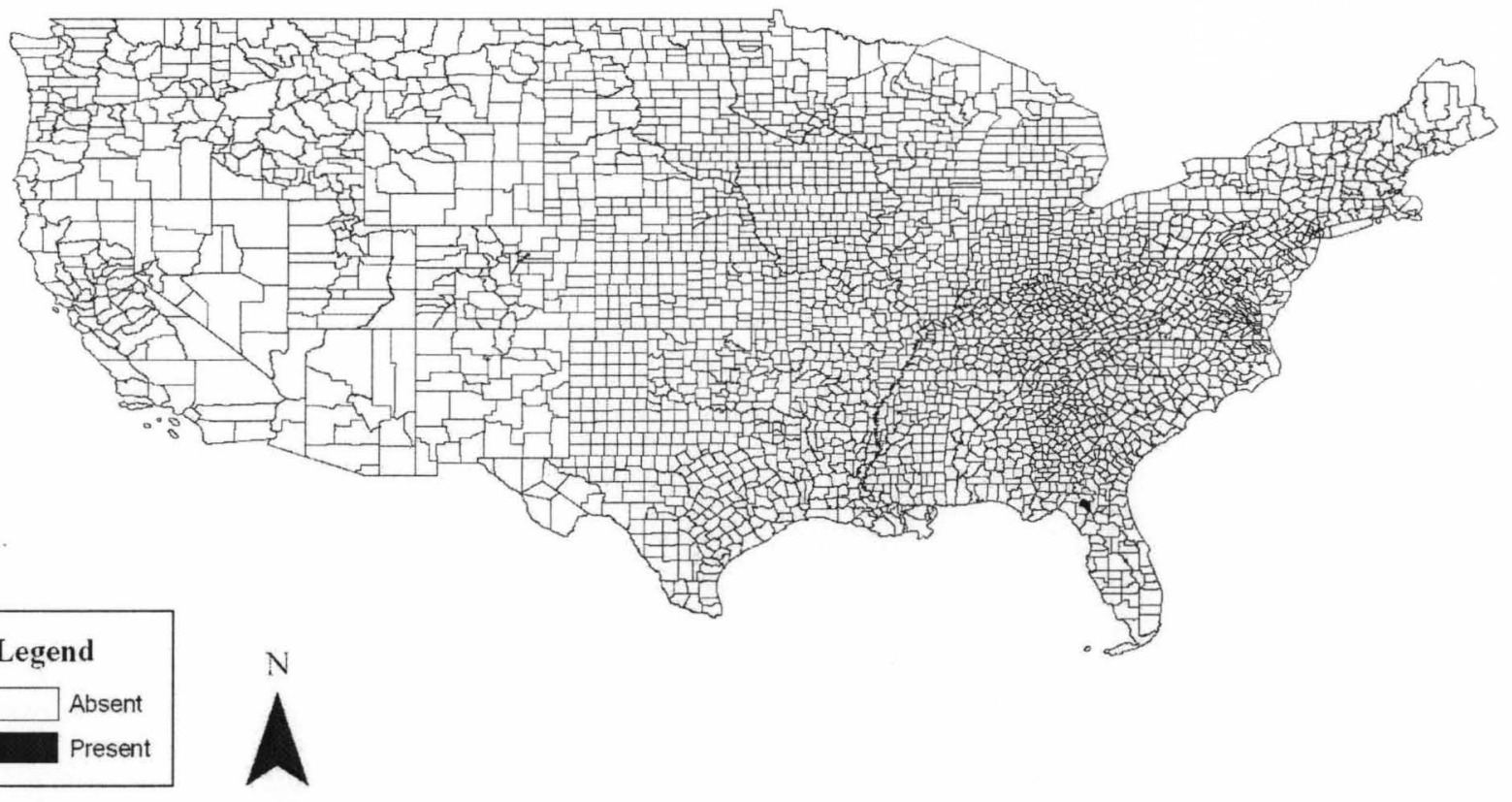

0 250500 


\section{BIOGEOGRAPHIC RANGE BY COUNTY IN THE CONTIGUOUS STATES}

Cionella lubrica

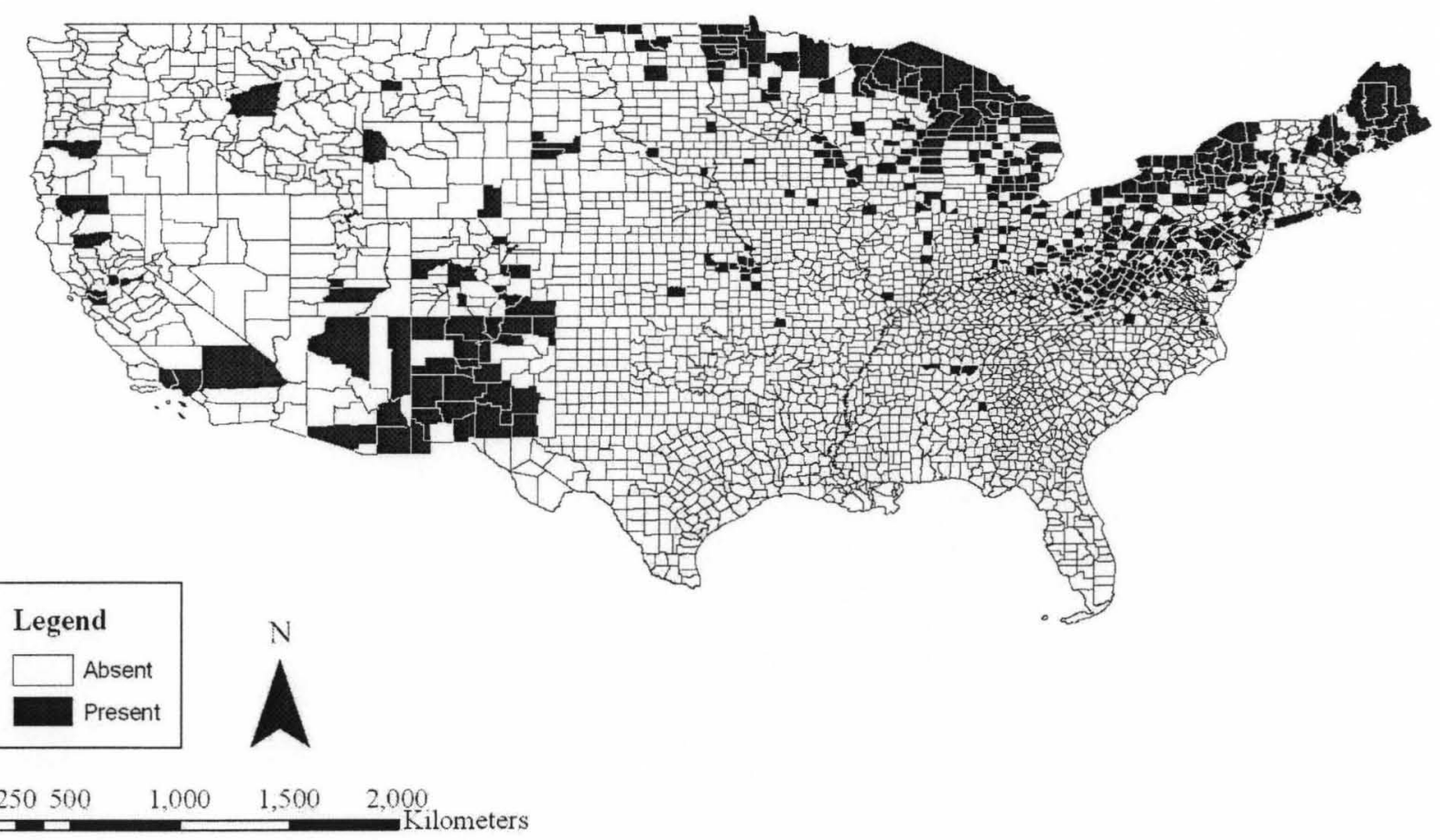


BIOGEOGRAPHIC RANGE BY COUNTY IN THE CONTIGUOUS STATES

Deroceras laeve

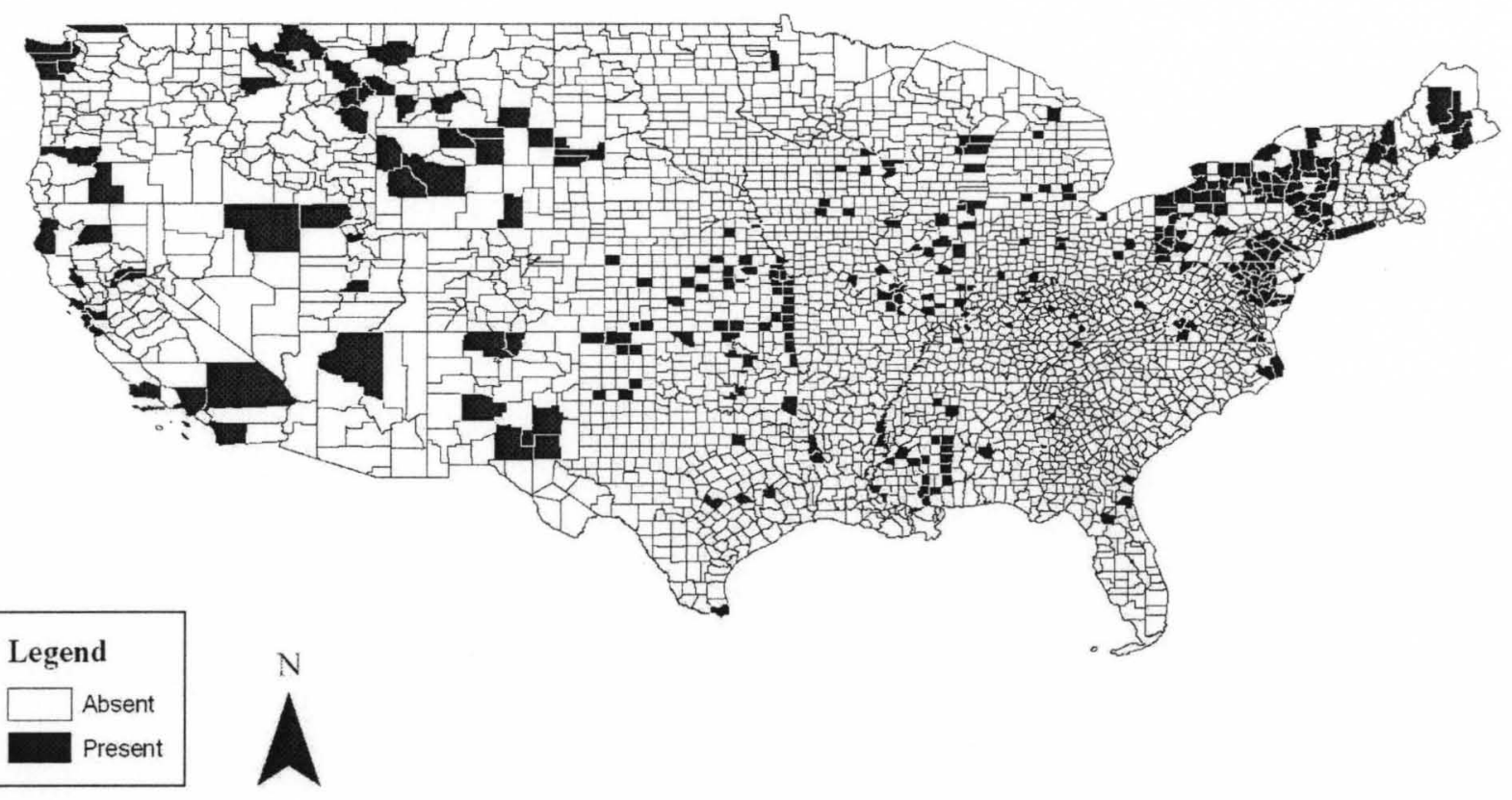

\begin{tabular}{lllll}
0 & 250500 & 1,000 & 1,500 & 2,000 \\
\hline
\end{tabular} 


\section{BIOGEOGRAPHIC RANGE BY COUNTY IN ALASKA}

Deroceras laeve

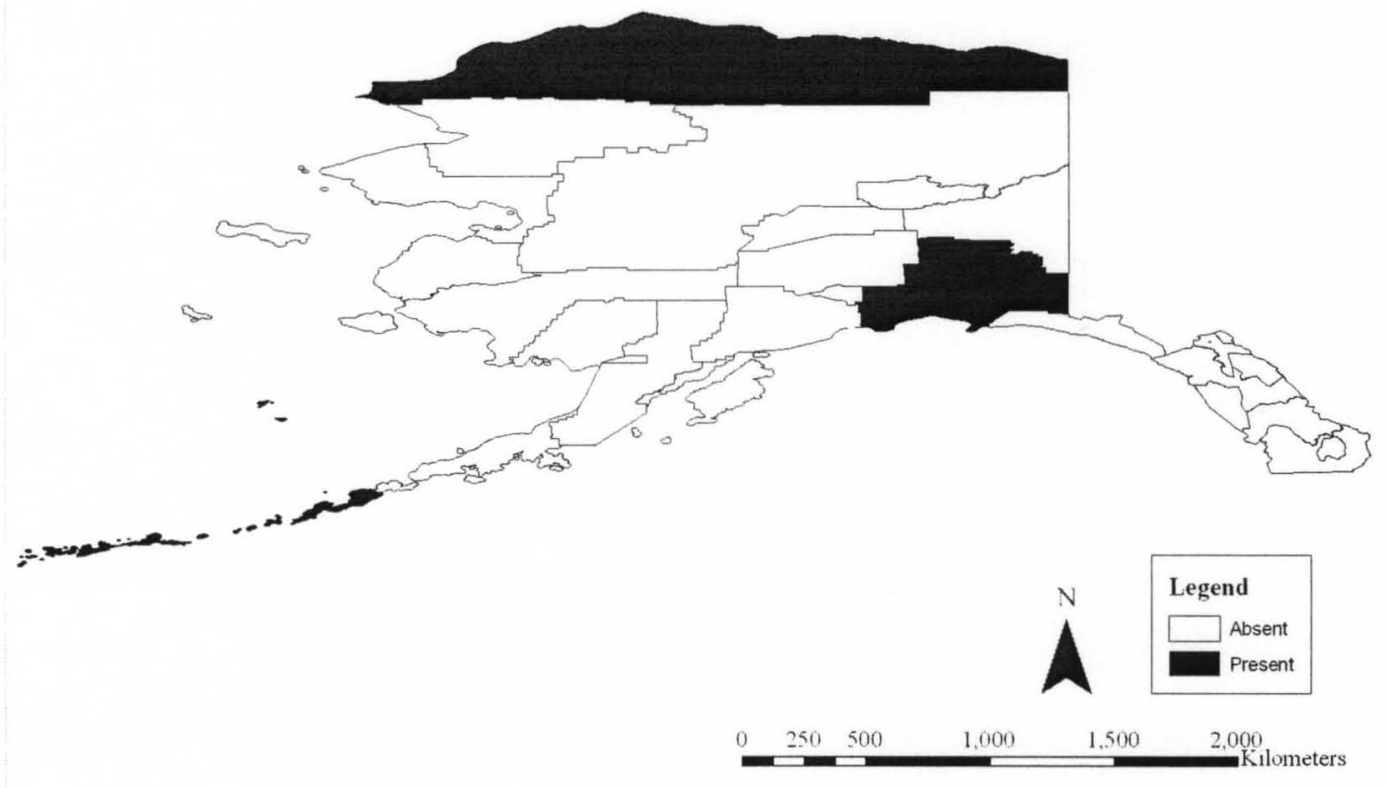

BIOGEOGRAPHIC RANGE BY COUNTY IN HAWAII

Deroceras laeve

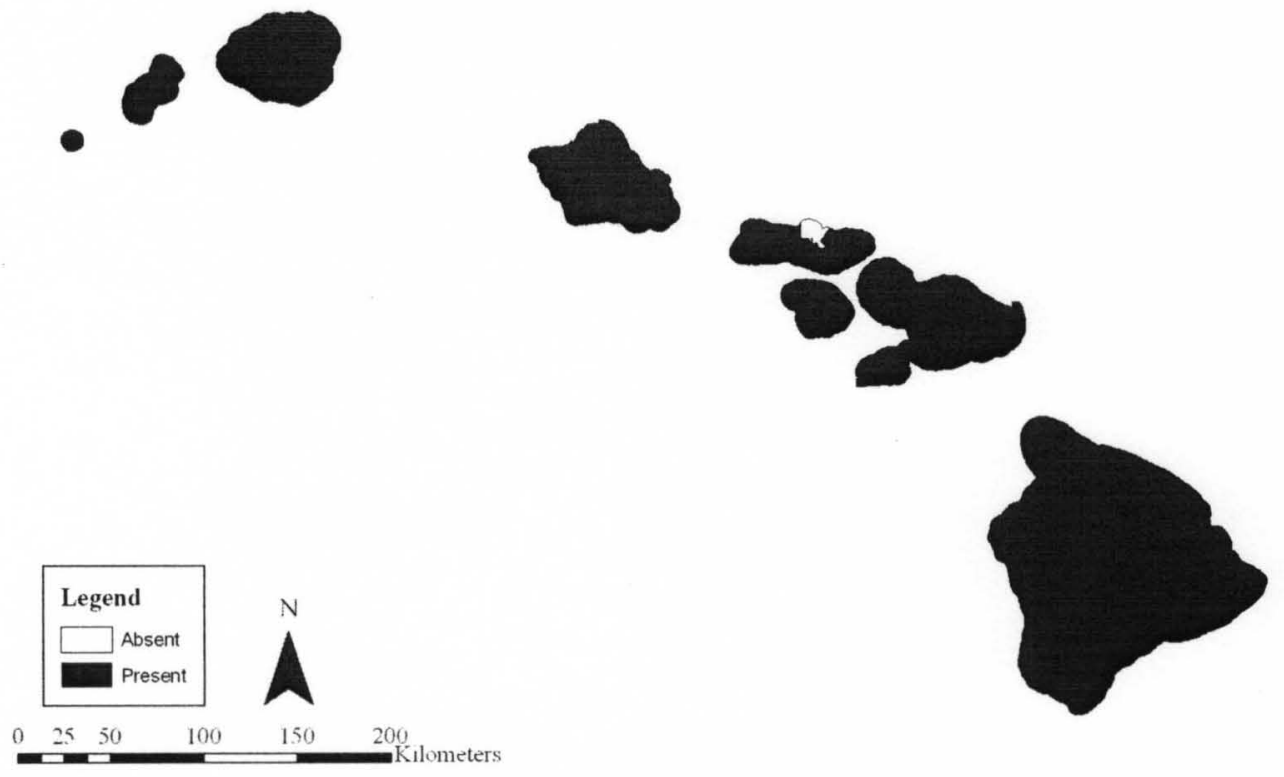


BIOGEOGRAPHIC RANGE BY COUNTY IN THE CONTIGUOUS STATES

Discus whitneyi

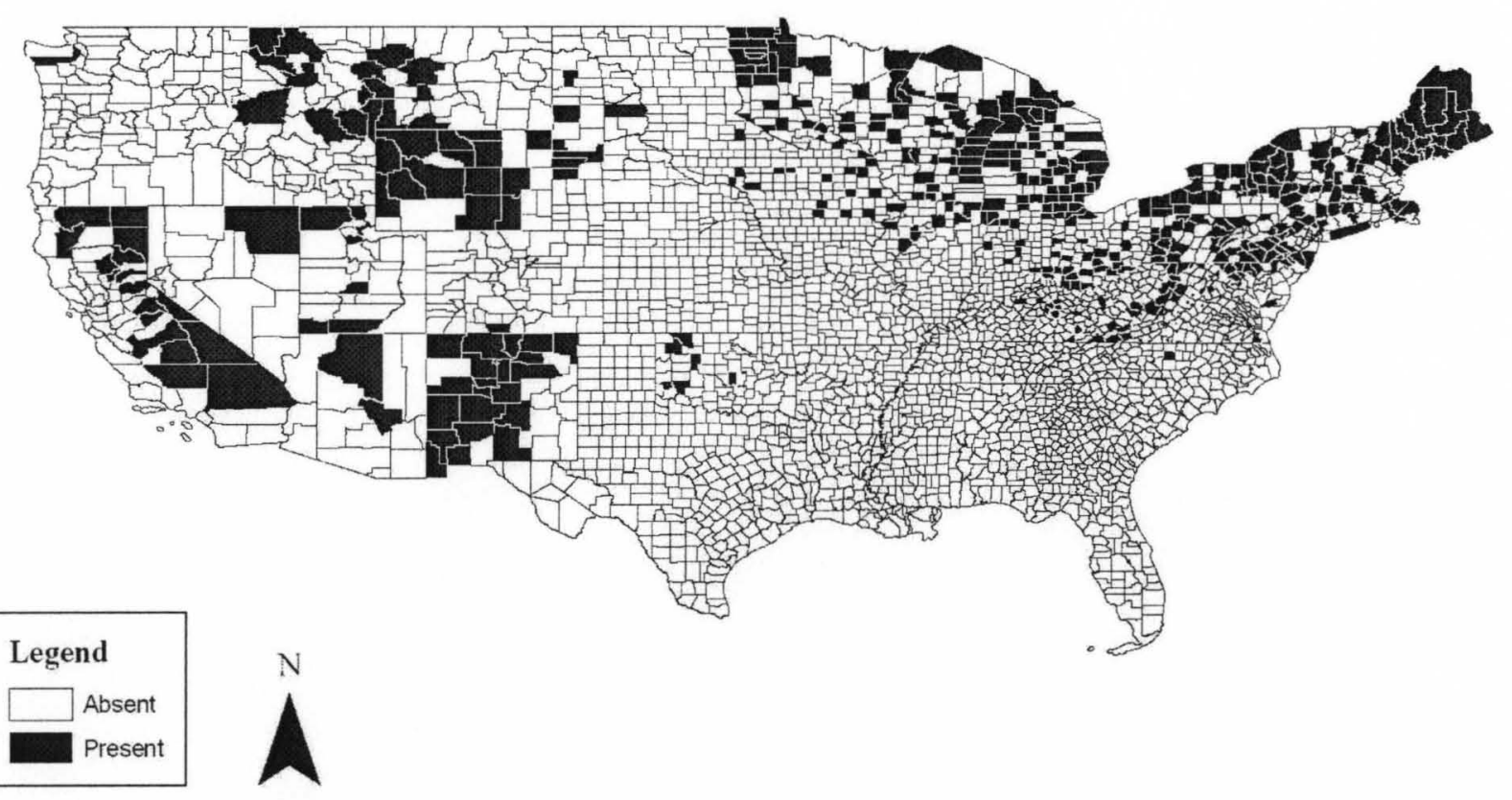

\begin{tabular}{llll}
$0 \quad 250 \quad 500 \quad 1,000$ & 1,500 & 2,000 \\
\hline
\end{tabular} 
BIOGEOGRAPHIC RANGE BY COUNTY IN ALASKA

Discus whitneyi

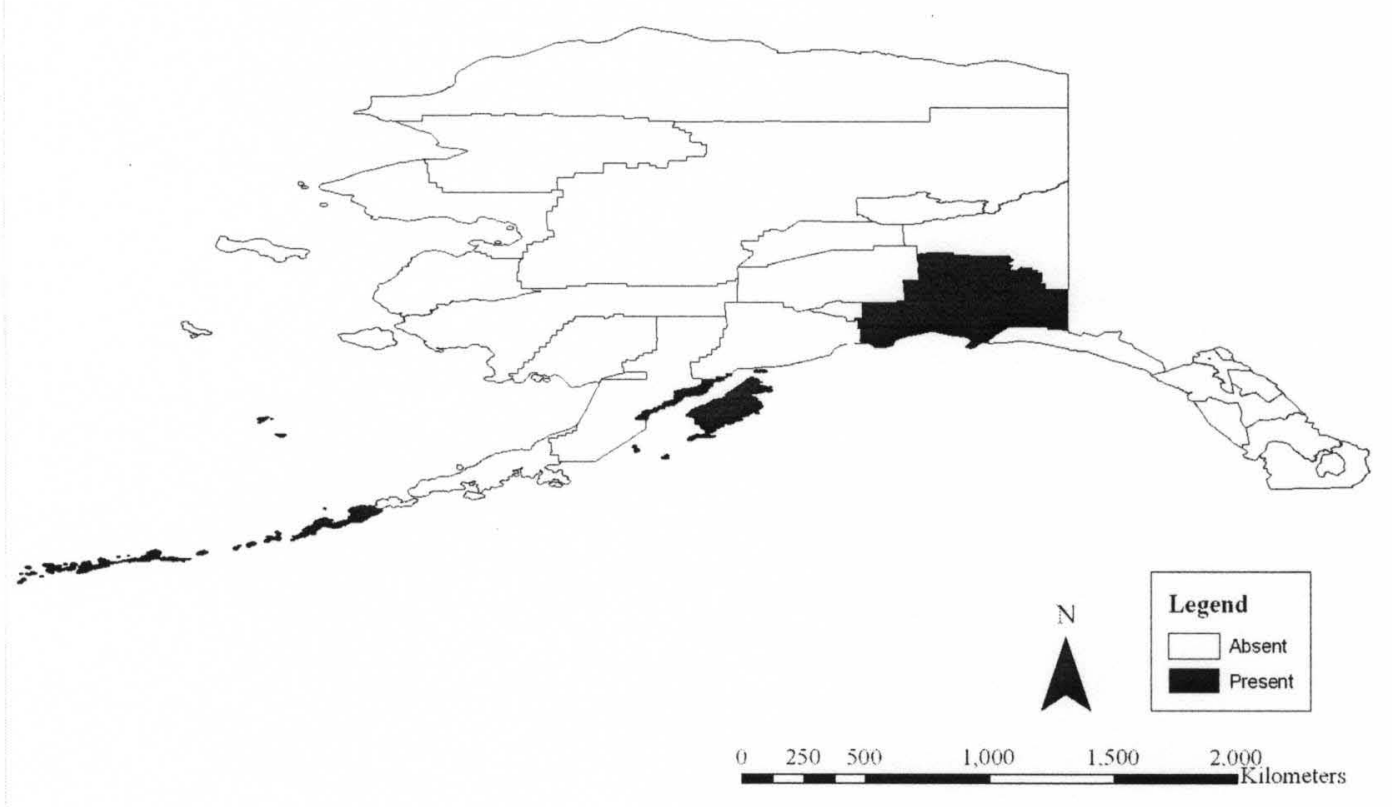




\section{BIOGEOGRAPHIC RANGE BY COUNTY IN THE CONTIGUOUS STATES}

Euchemotrema fraternum

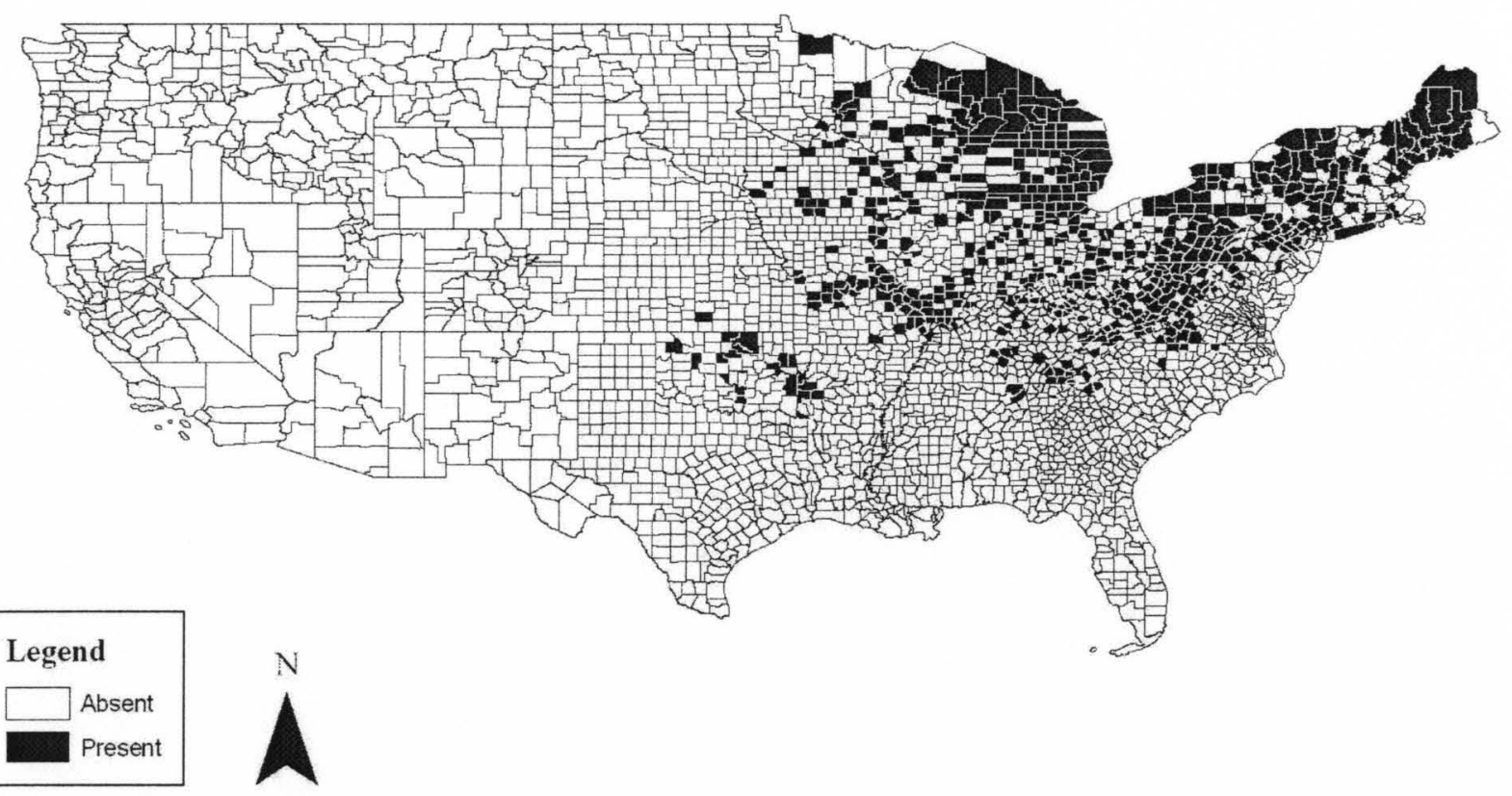

$0 \quad 250500$

$1,000 \quad 1,500$

Kilometers 


\section{BIOGEOGRAPHIC RANGE BY COUNTY IN THE CONTIGUOUS STATES}

Euconulus fulvus

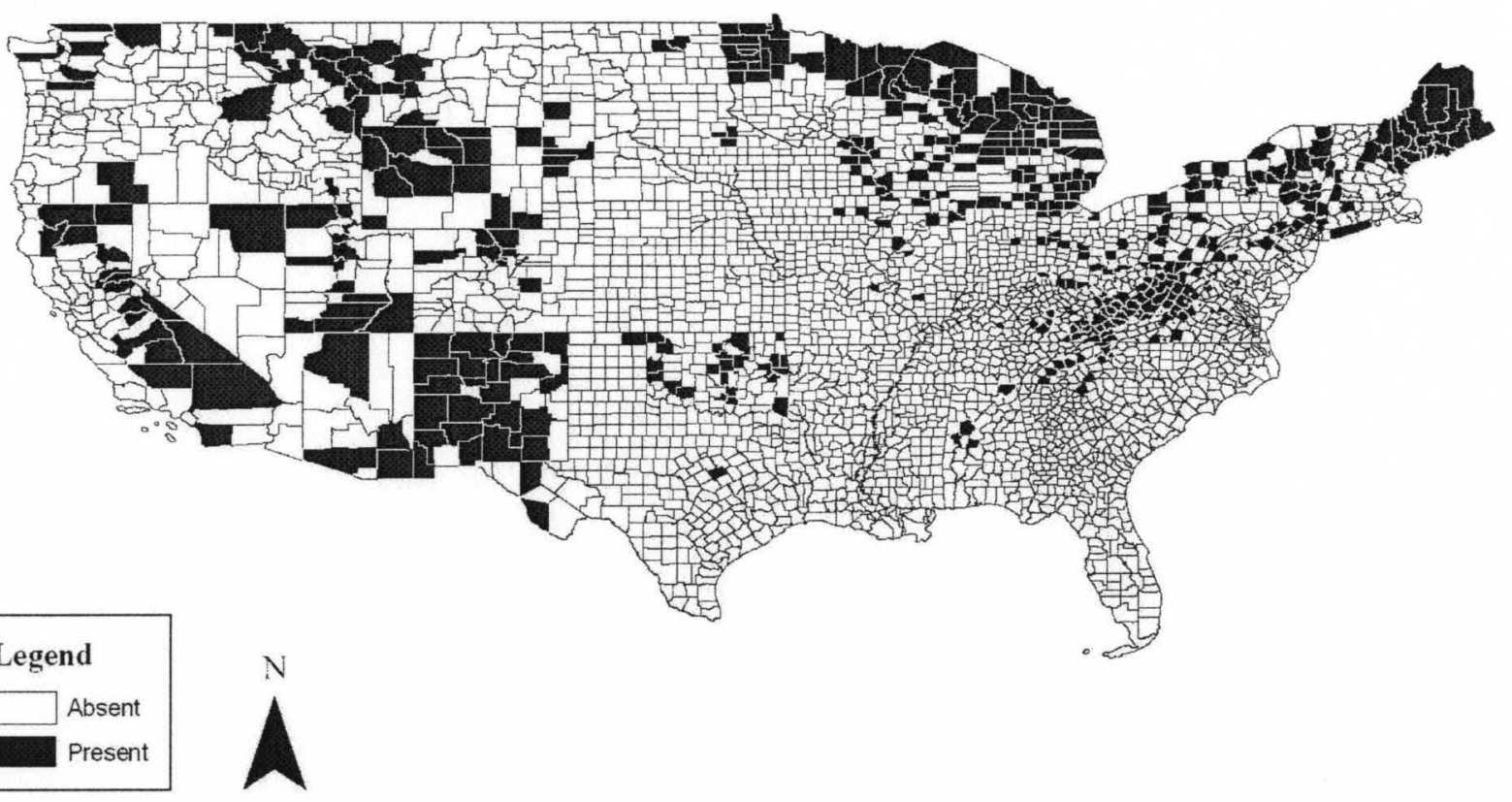

\begin{tabular}{lllll}
$0 \quad 250500 \quad 1,000$ & 1,500 & 2,000 \\
\hline
\end{tabular} 
BIOGEOGRAPHIC RANGE BY COUNTY IN ALASKA

Euconulus fulvus

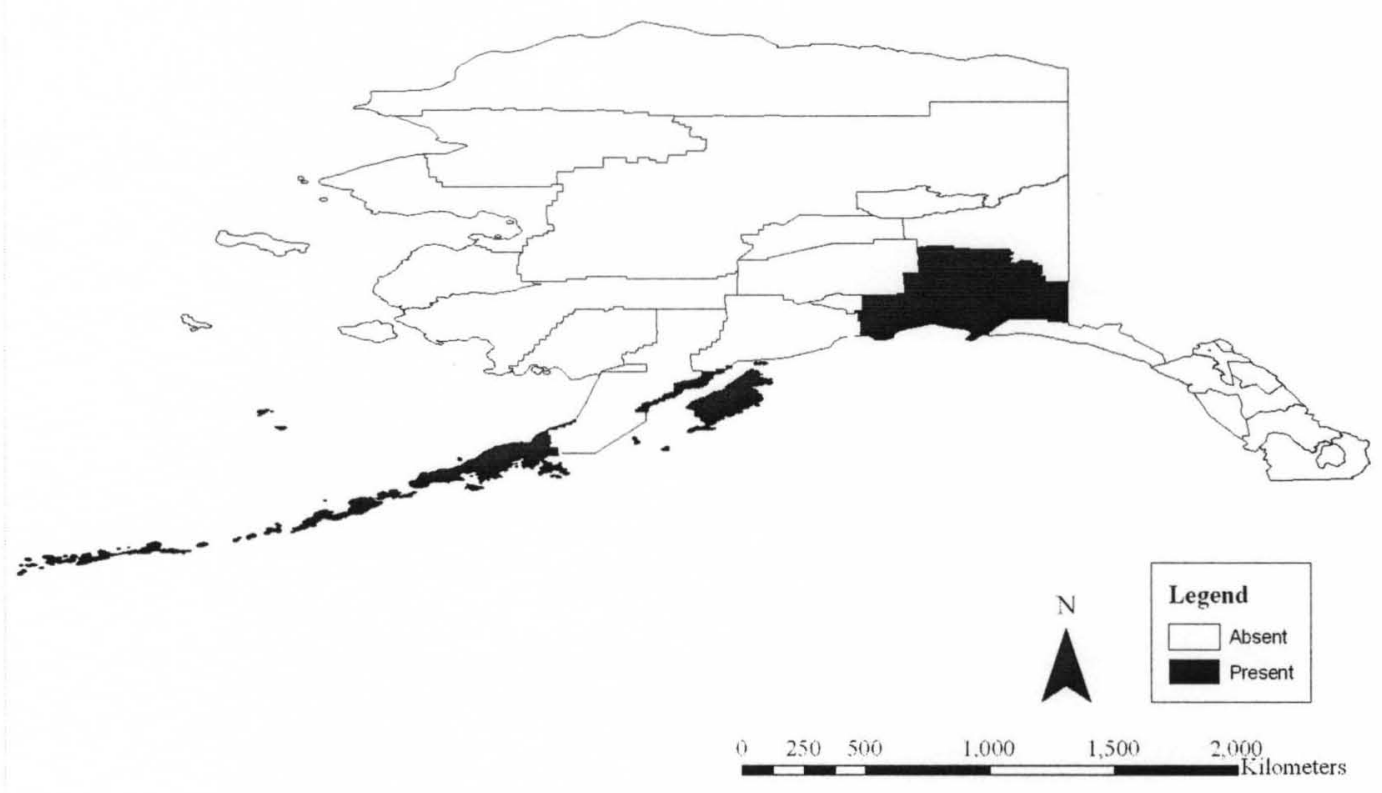


BIOGEOGRAPHIC RANGE BY COUNTY IN THE CONTIGUOUS STATES

Ferrissia fragilis

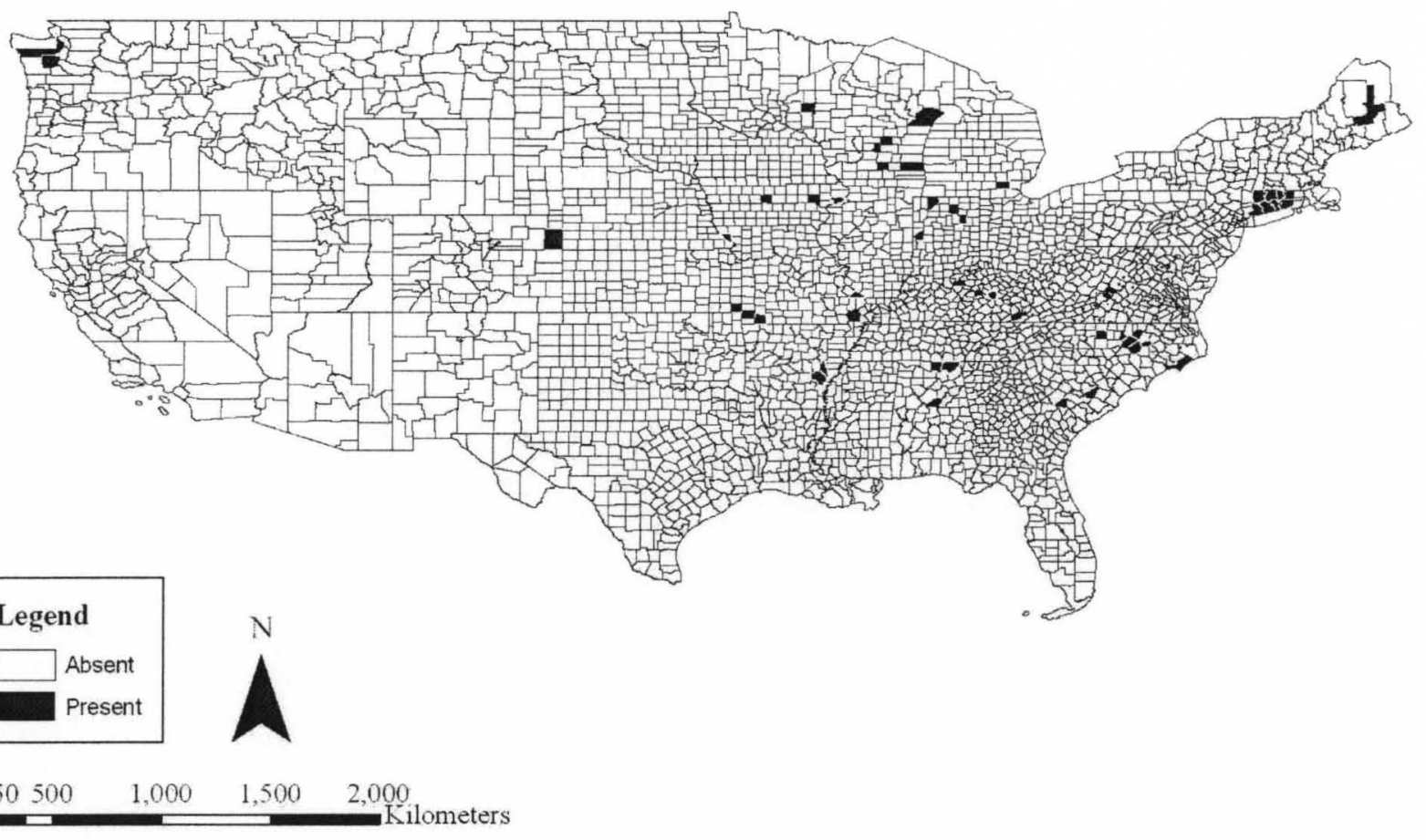


BIOGEOGRAPHIC RANGE BY COUNTY IN THE CONTIGUOUS STATES

Fossaria bulimoides

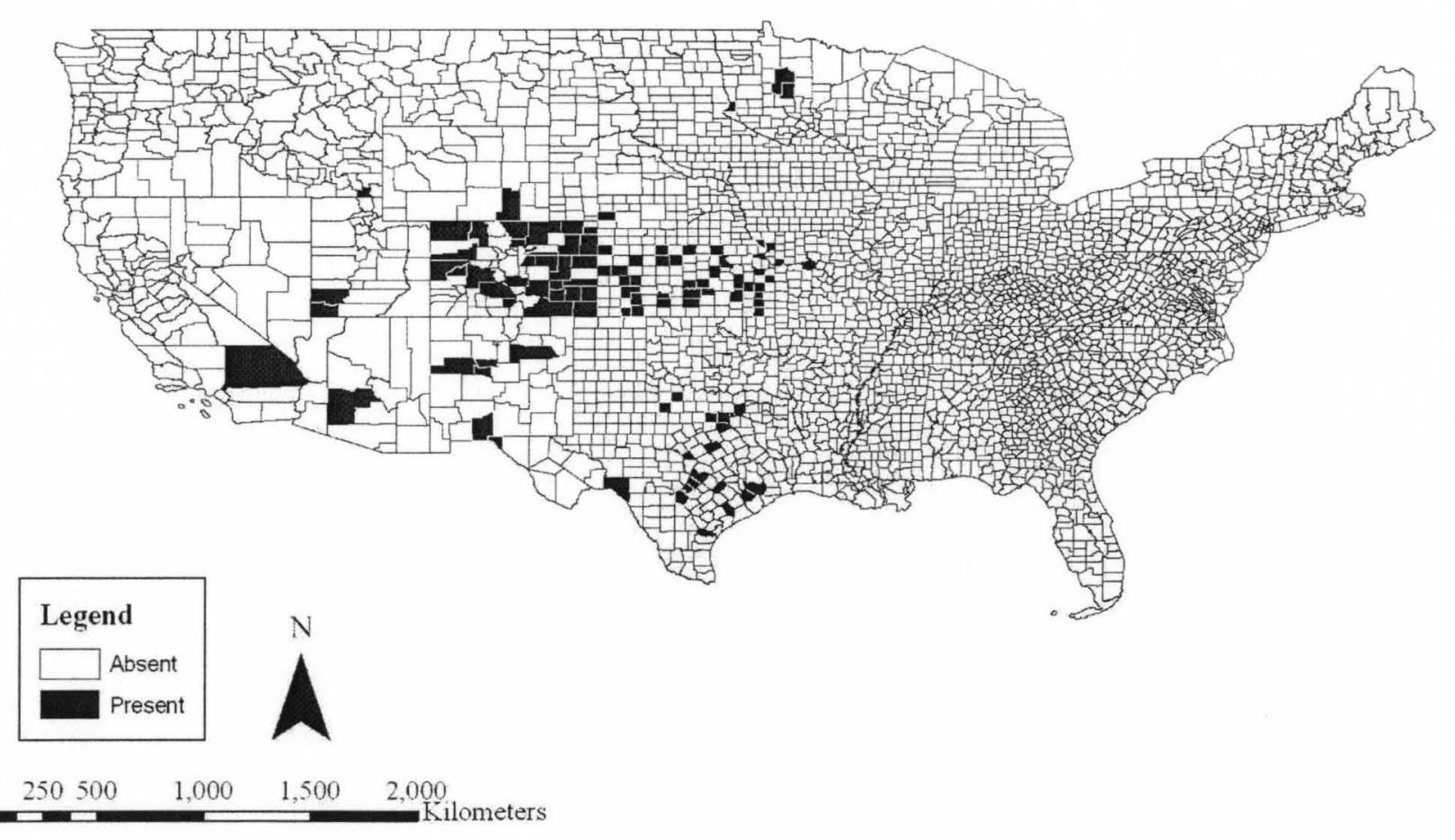


BIOGEOGRAPHIC RANGE BY COUNTY IN THE CONTIGUOUS STATES

Fossaria dalli

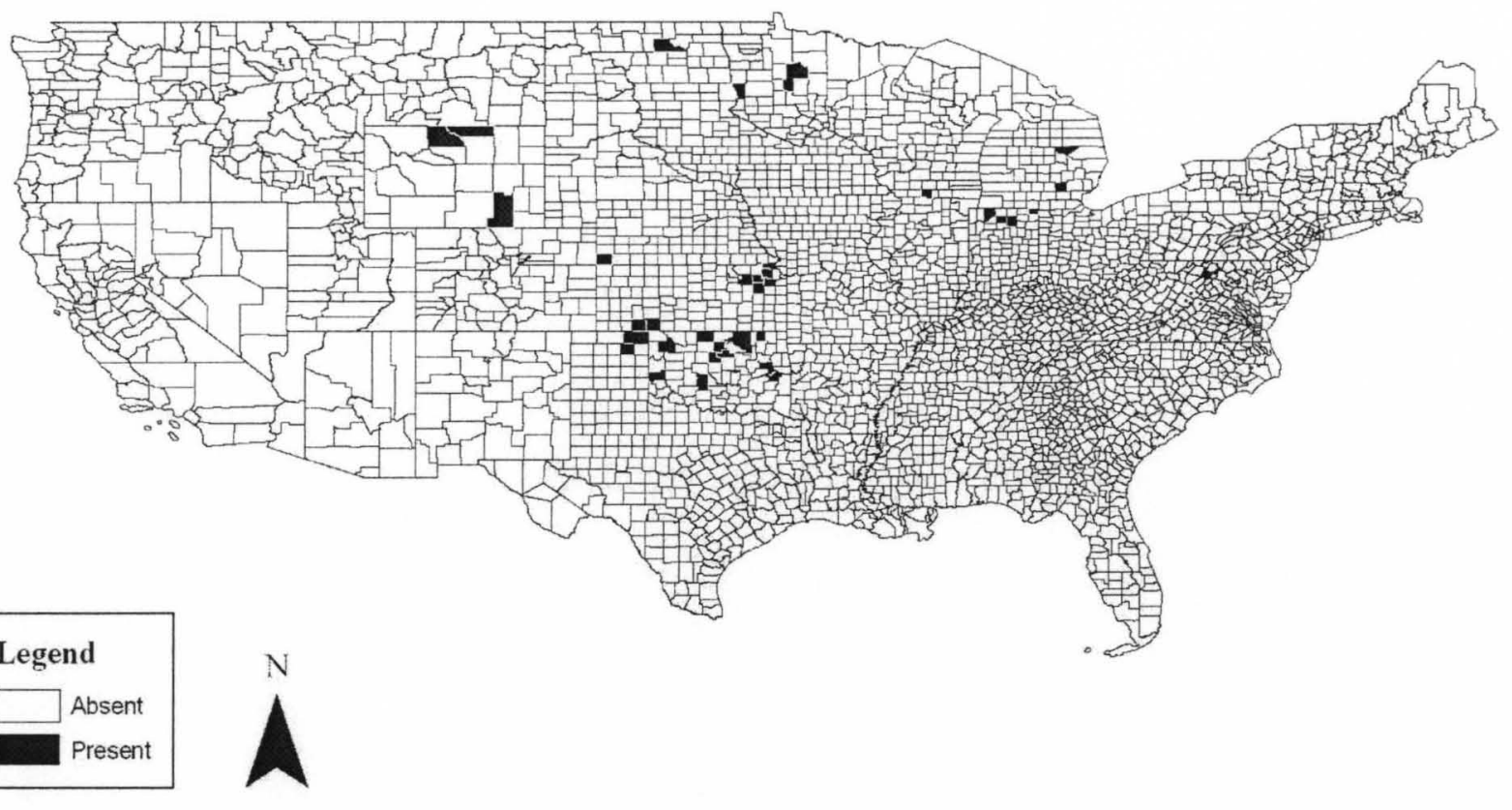

\begin{tabular}{lllll}
0 & $250500 \quad 1,000$ & $1,500 \quad 2,000$ \\
\hline
\end{tabular} 
BIOGEOGRAPHIC RANGE BY COUNTY IN THE CONTIGUOUS STATES

Fossaria humilis

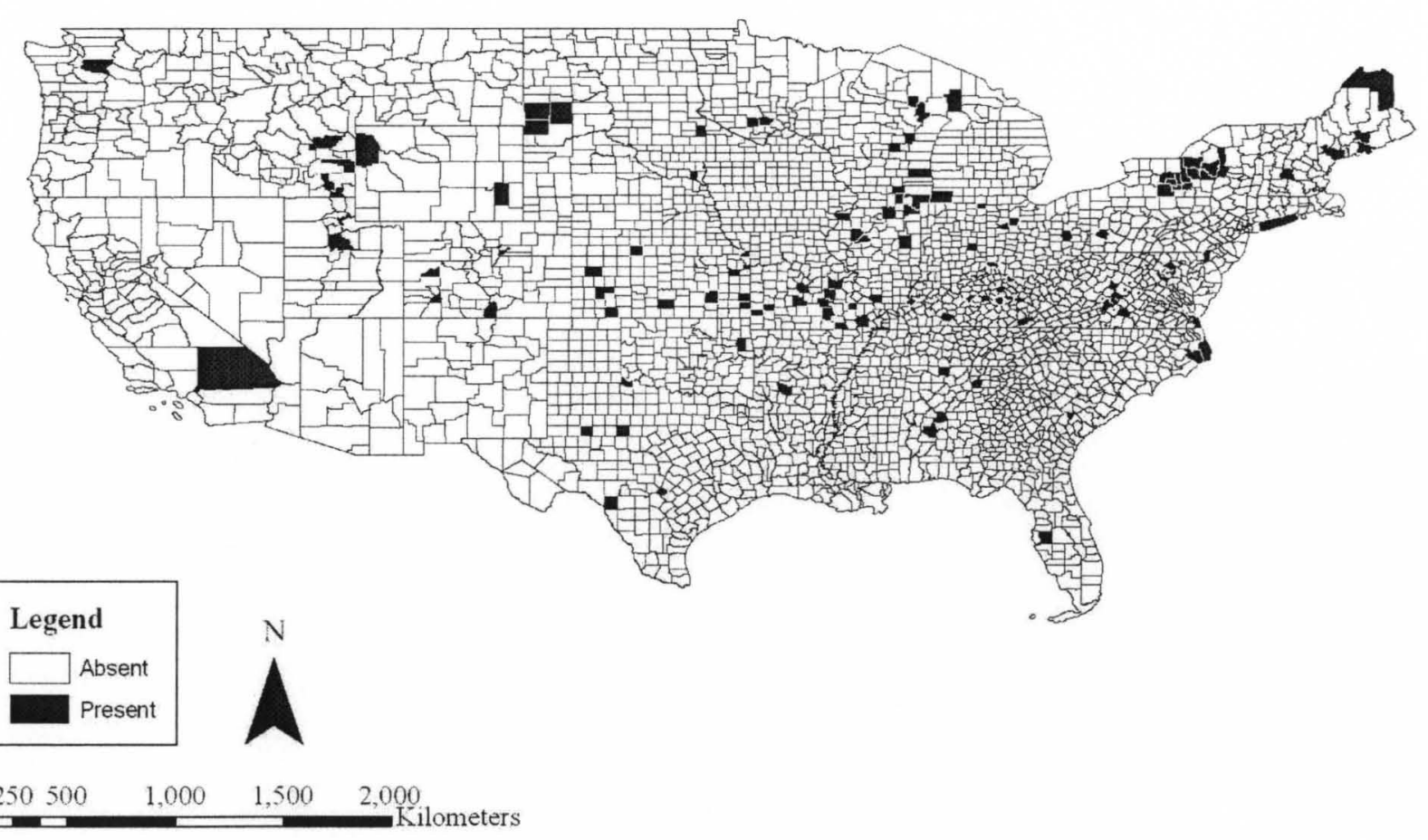


BIOGEOGRAPHIC RANGE BY COUNTY IN ALASKA

Fossaria humilis

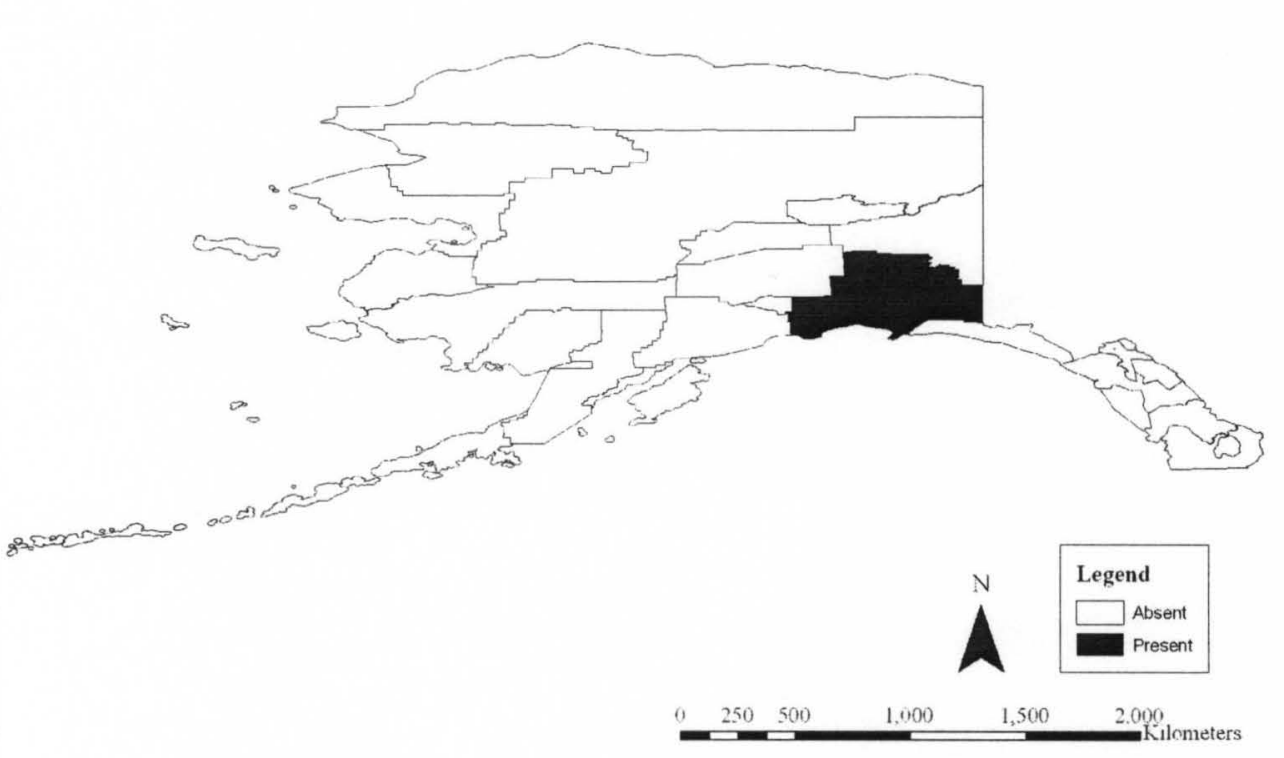


BIOGEOGRAPHIC RANGE BY COUNTY IN THE CONTIGUOUS STATES

Fossaria modicella

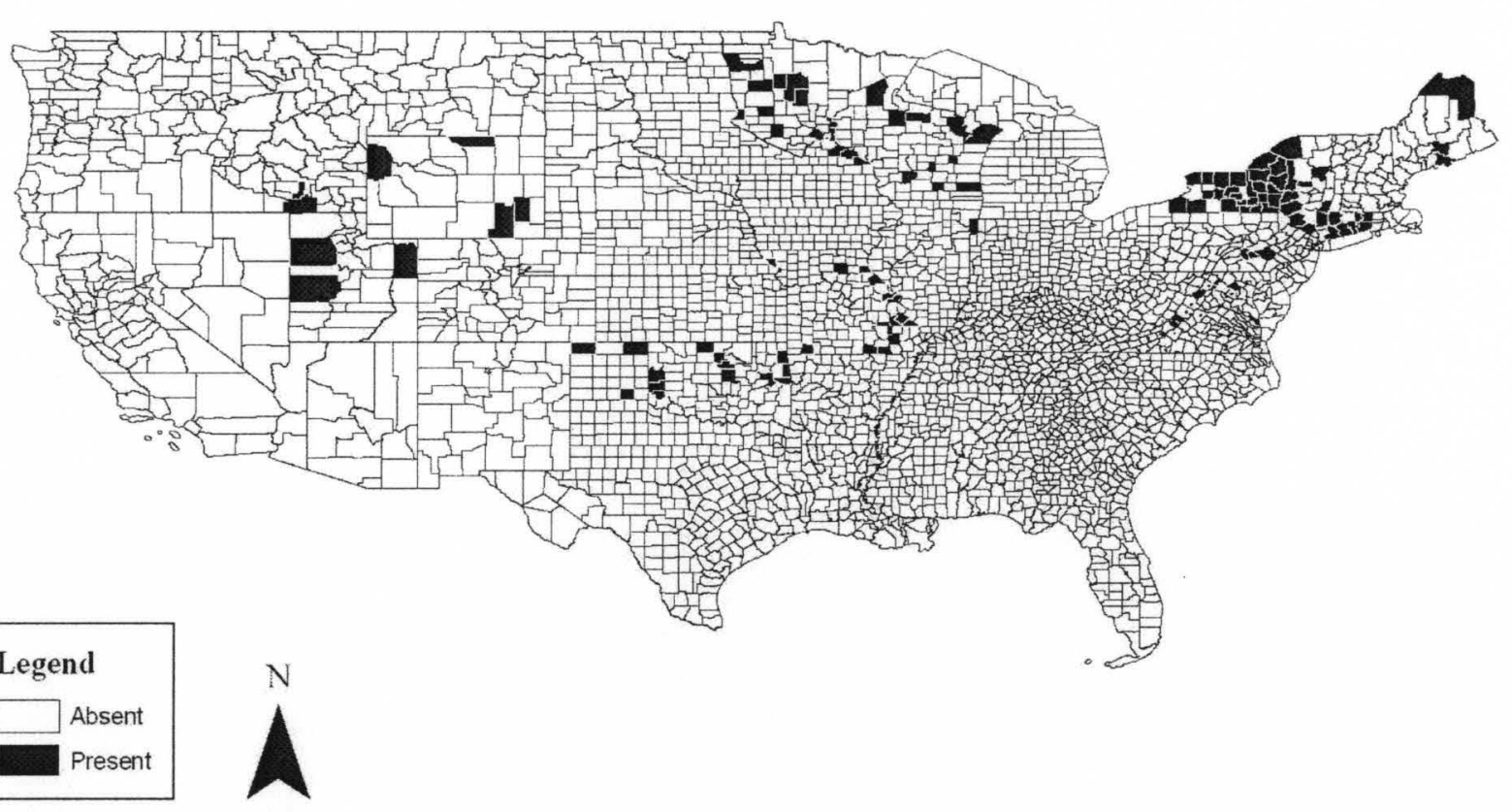

250500

1,000

2,000

Kilometers 
BIOGEOGRAPHIC RANGE BY COUNTY IN THE CONTIGUOUS STATES

Fossaria obrussa

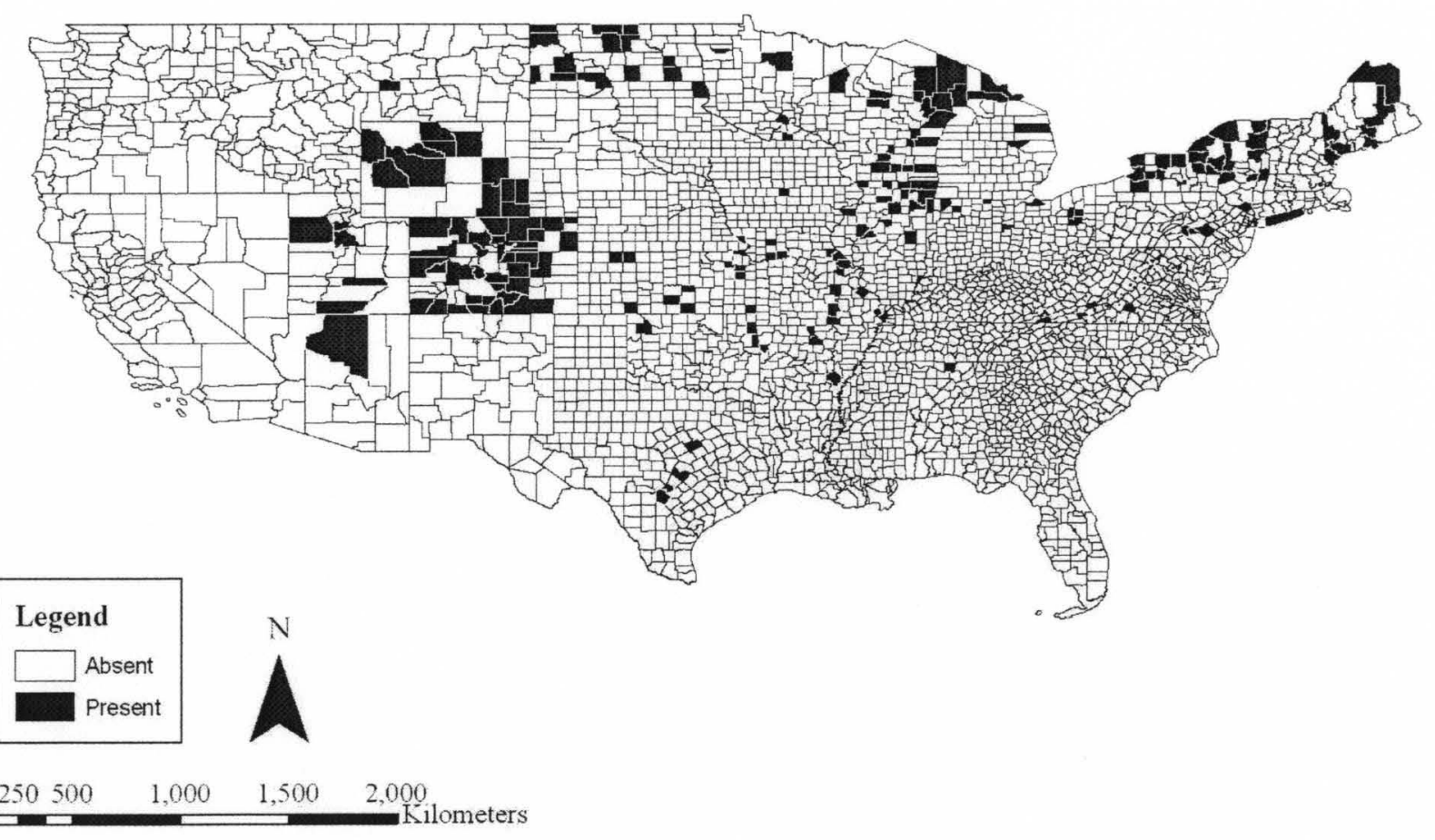



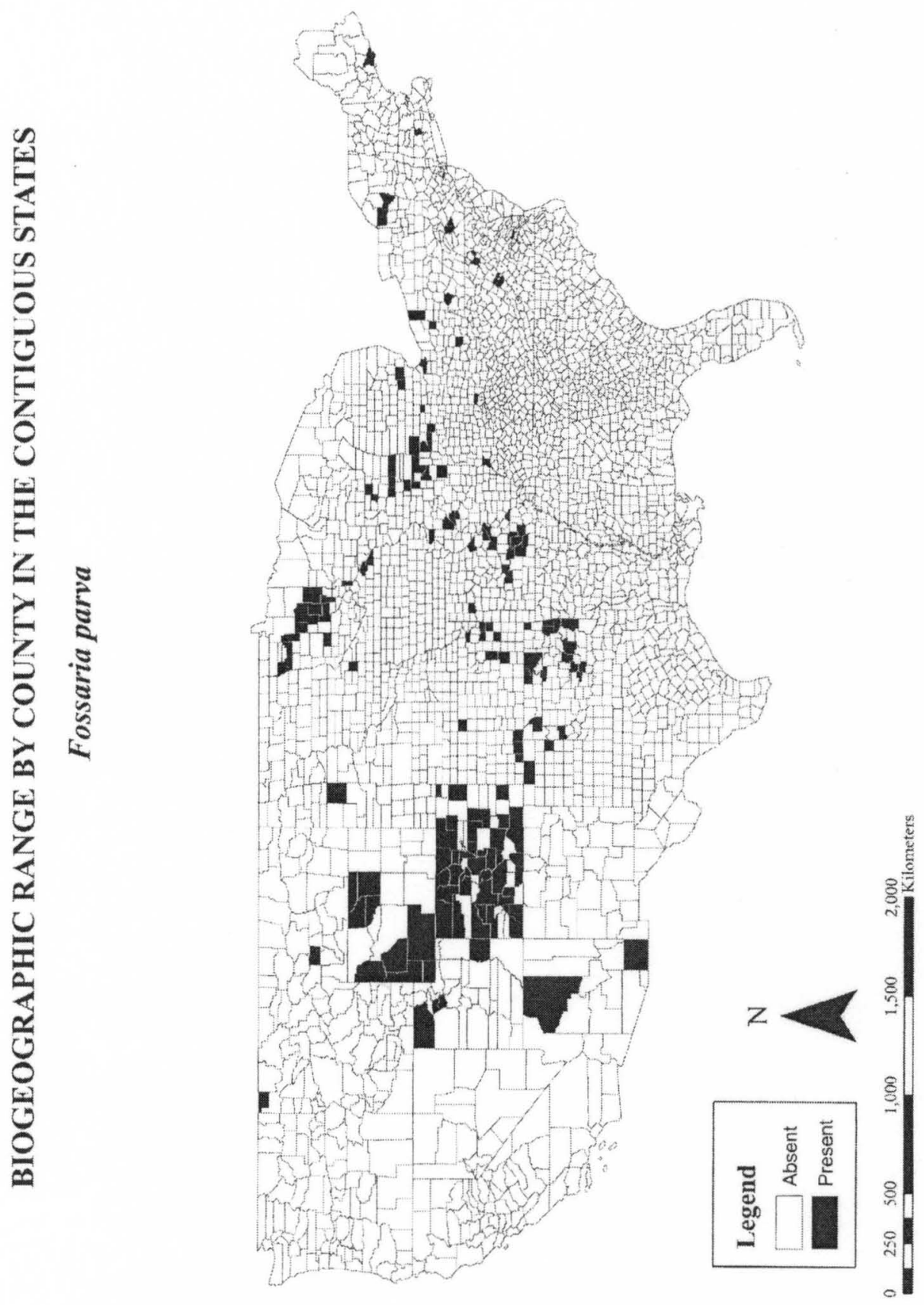


\section{BIOGEOGRAPHIC RANGE BY COUNTY IN THE CONTIGUOUS STATES}

Gastrocopta armifera

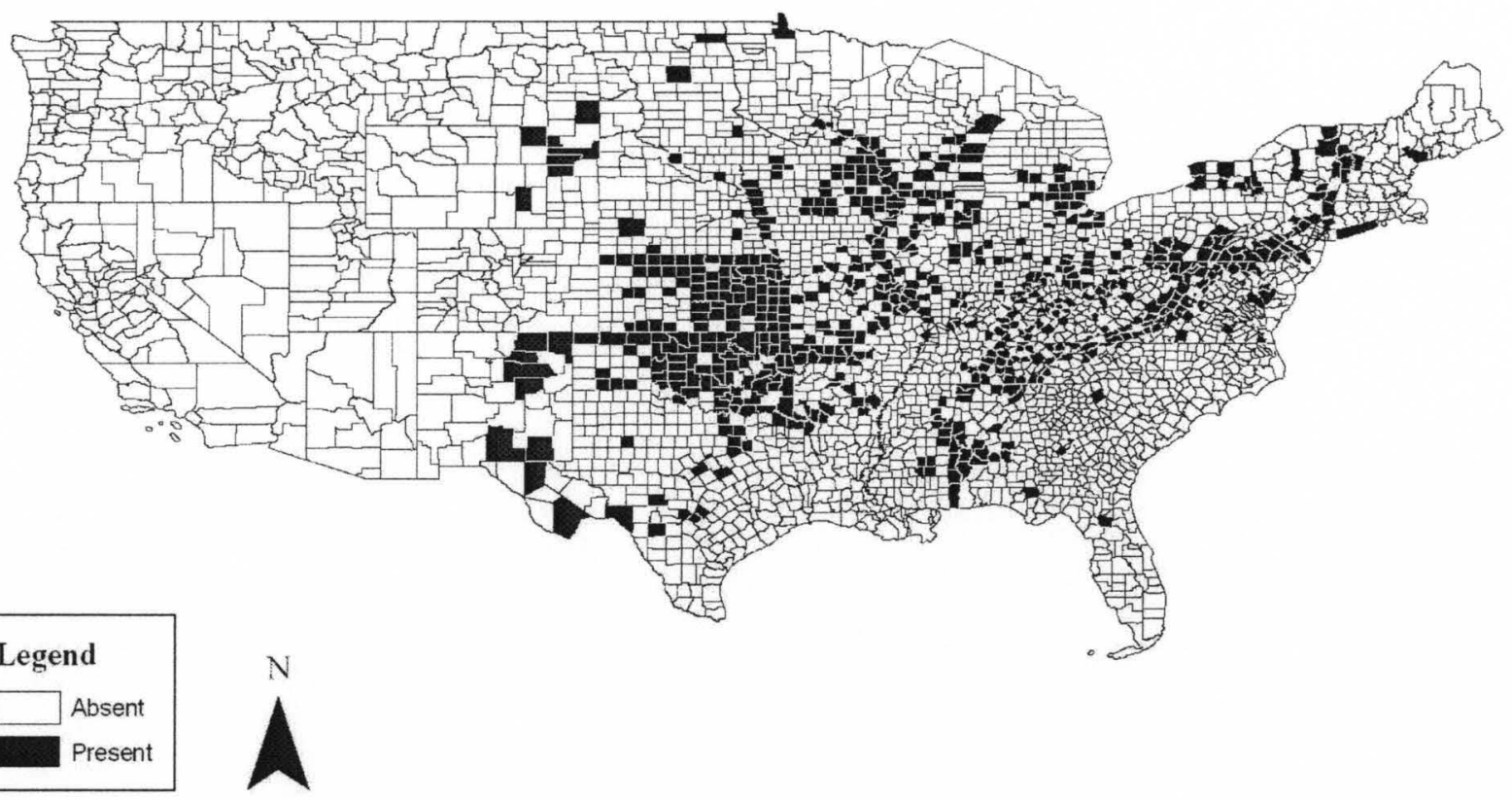

$0 \quad 250500$

$1,000 \quad 1,500 \quad 2,000$

Kilometers 
BIOGEOGRAPHIC RANGE BY COUNTY IN THE CONTIGUOUS STATES

Gastrocopta contracta

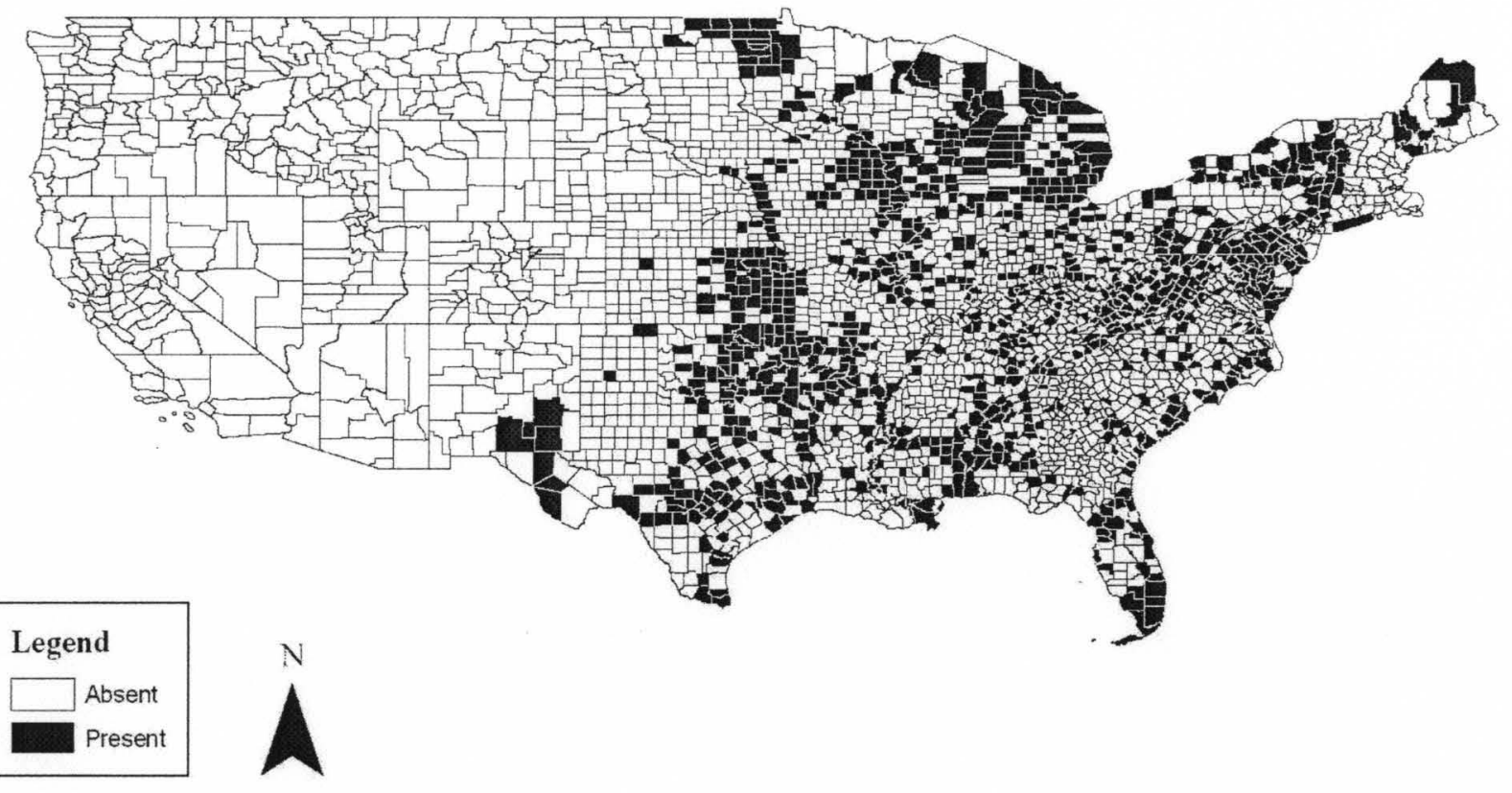

$0 \quad 250500$

$1,000 \quad 1,500$

2,000 Kilometers 
BIOGEOGRAPHIC RANGE BY COUNTY IN THE CONTIGUOUS STATES

Gastrocopta cristata

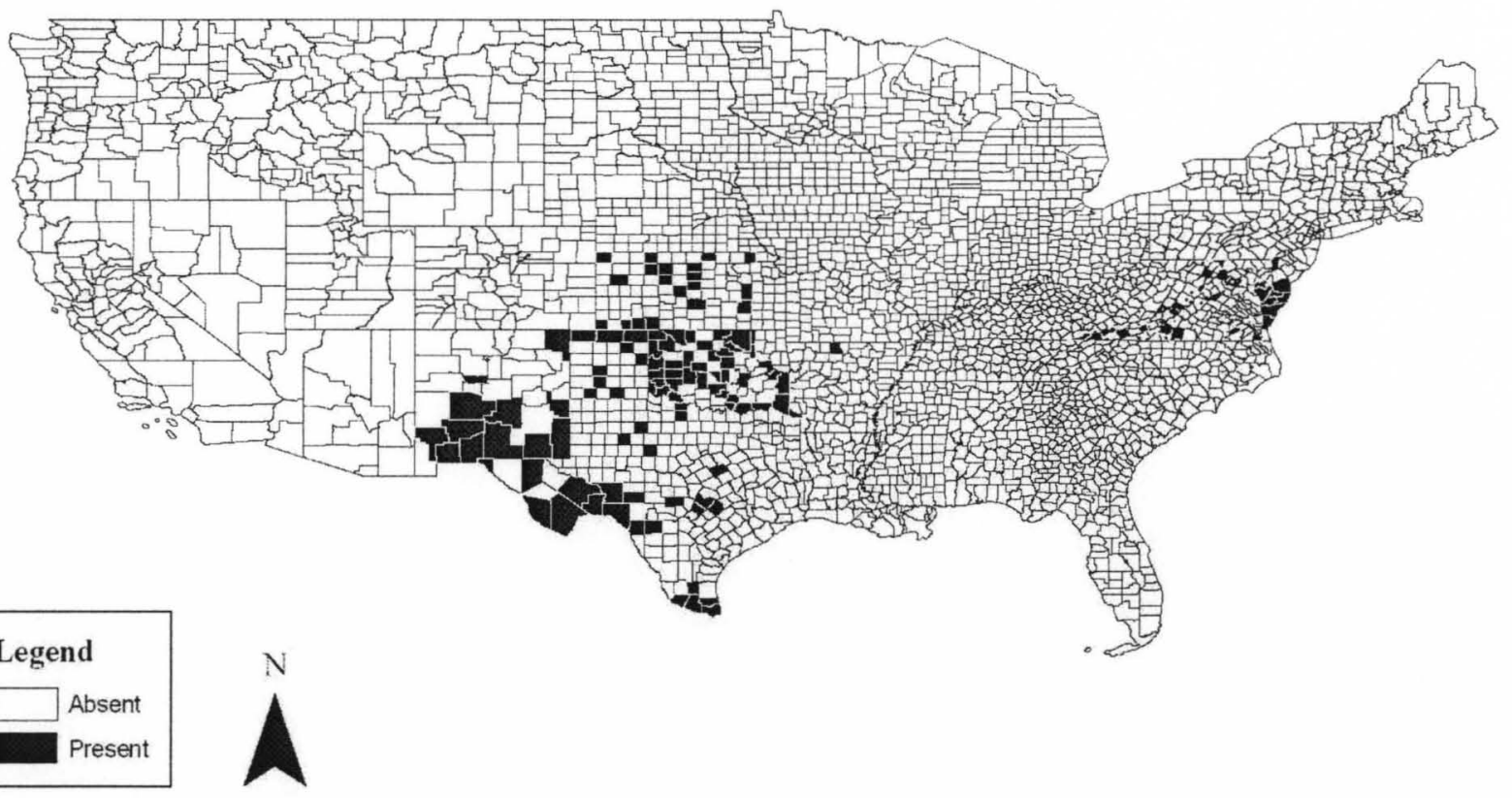

$0 \quad 250500$

$1,000 \quad 1,500 \quad 2000$

Kilometers 
BIOGEOGRAPHIC RANGE BY COUNTY IN THE CONTIGUOUS STATES

Gastrocopta holzingeri

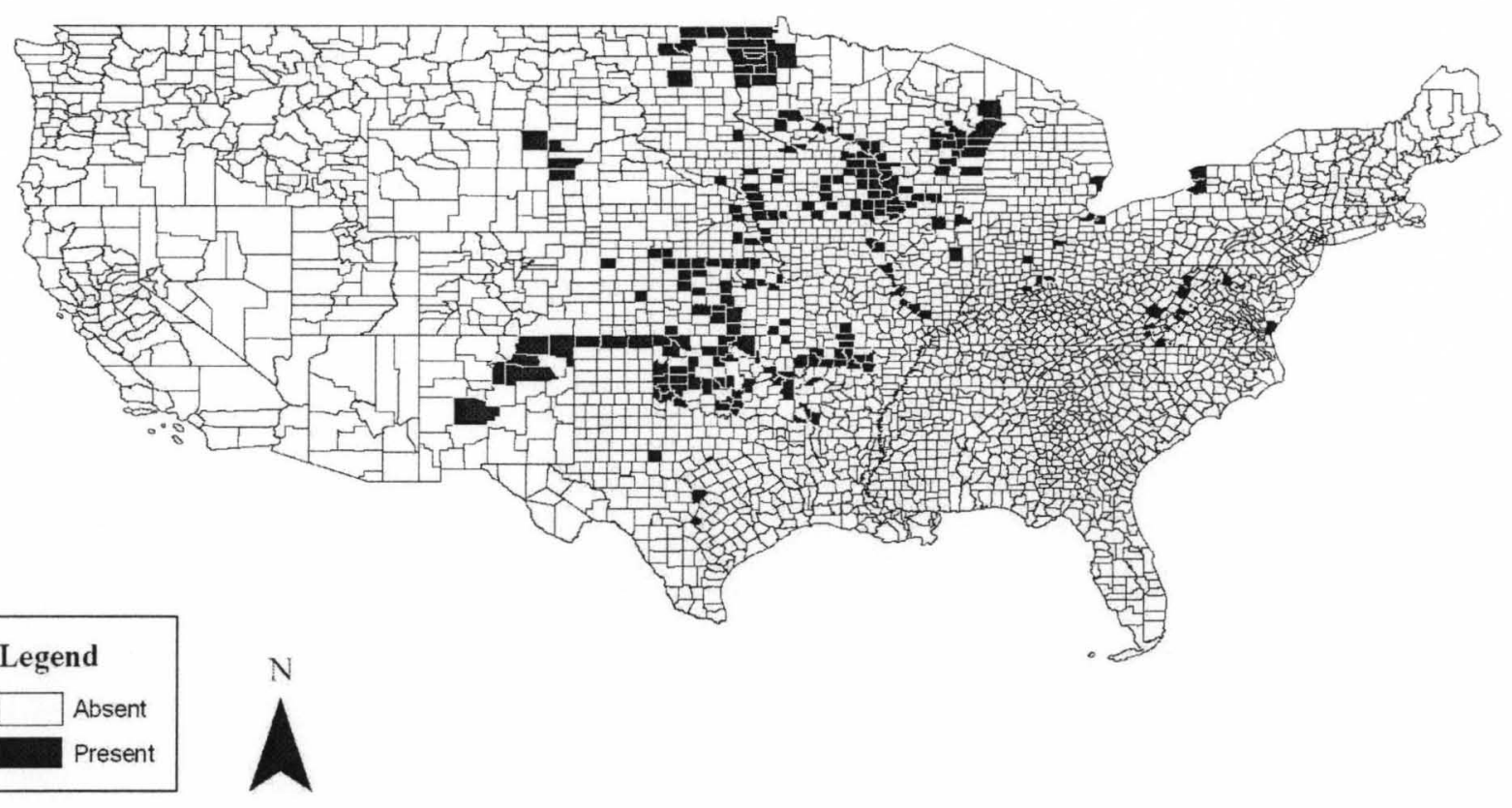

\begin{tabular}{llll}
250 & $500 \quad 1,000$ & 1,500 & 2,000 \\
\hline
\end{tabular} 


\section{BIOGEOGRAPHIC RANGE BY COUNTY IN THE CONTIGUOUS STATES}

Gastrocopta pellucida

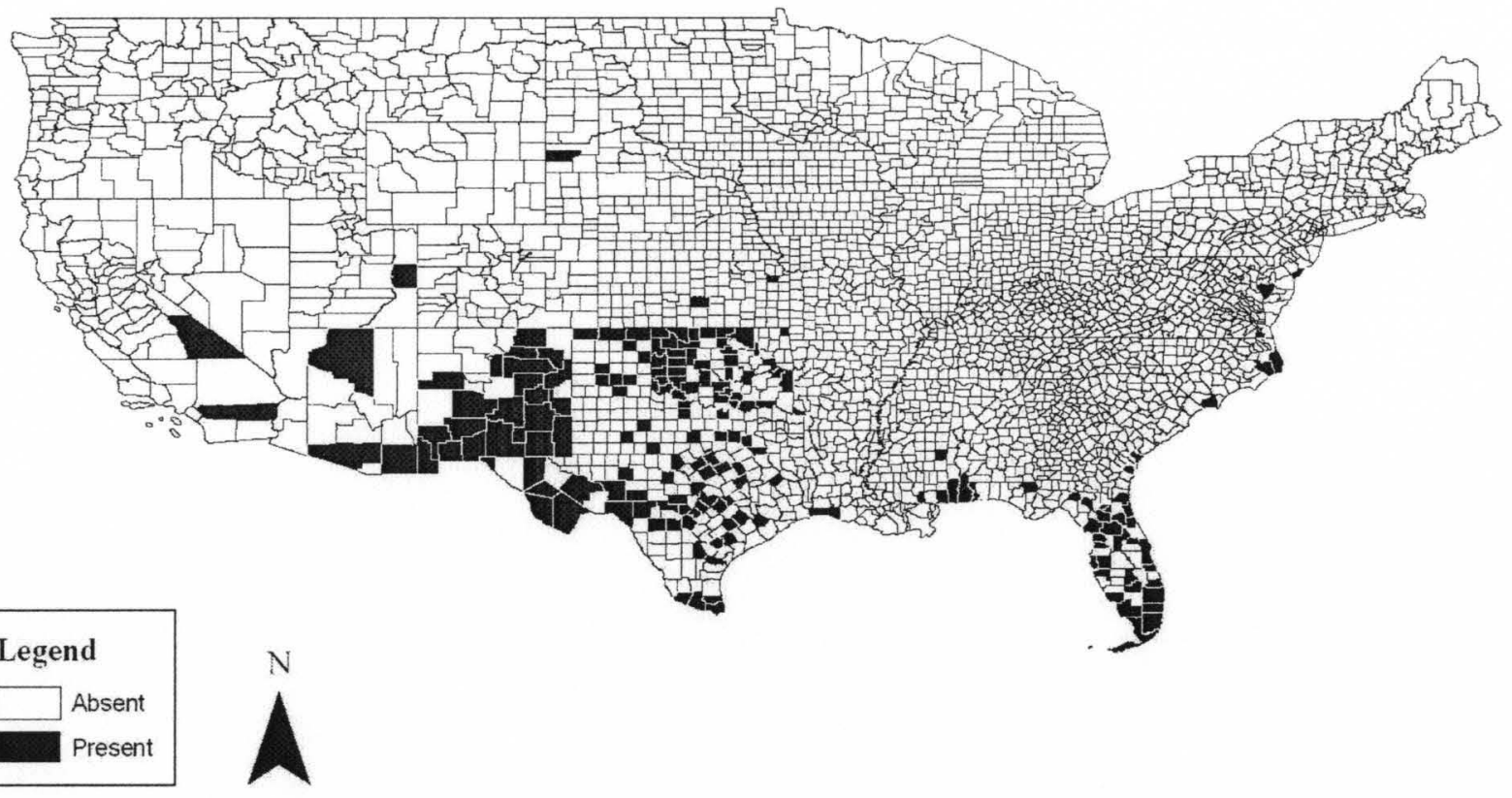

$0 \quad 250500$

$1,000 \quad 1,500 \quad 2,000$

Kilometers 
BIOGEOGRAPHIC RANGE BY COUNTY IN THE CONTIGUOUS STATES

Gastrocopta pentodon

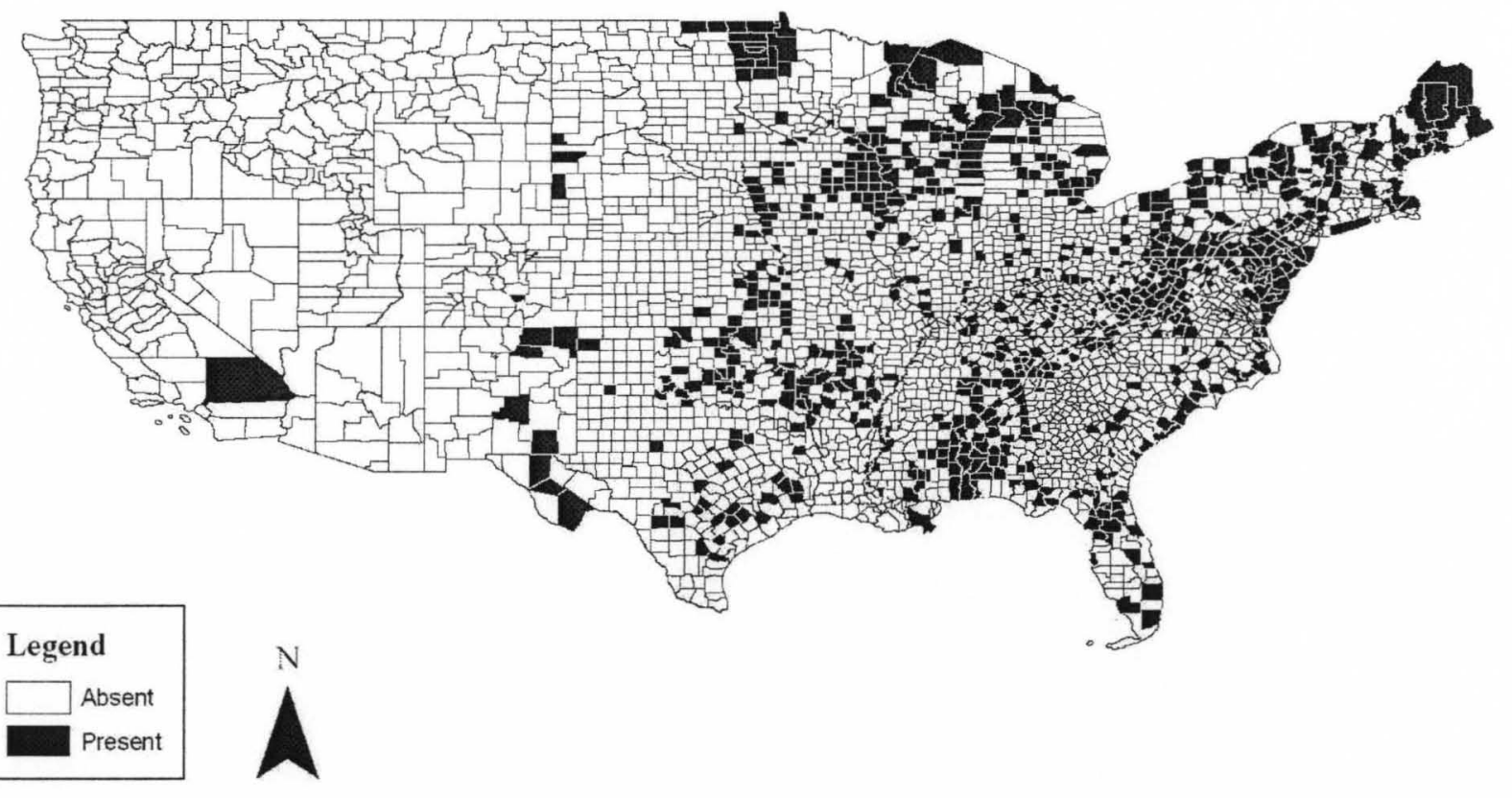

$0 \quad 250500$

$\begin{array}{lll}1,000 & 1,500 \quad 2000\end{array}$

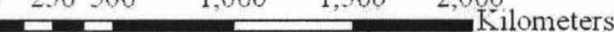


BIOGEOGRAPHIC RANGE BY COUNTY IN THE CONTIGUOUS STATES

Gastrocopta procera



- 250500

1,000 


\section{BIOGEOGRAPHIC RANGE BY COUNTY IN THE CONTIGUOUS STATES}

Gastrocopta riograndensis

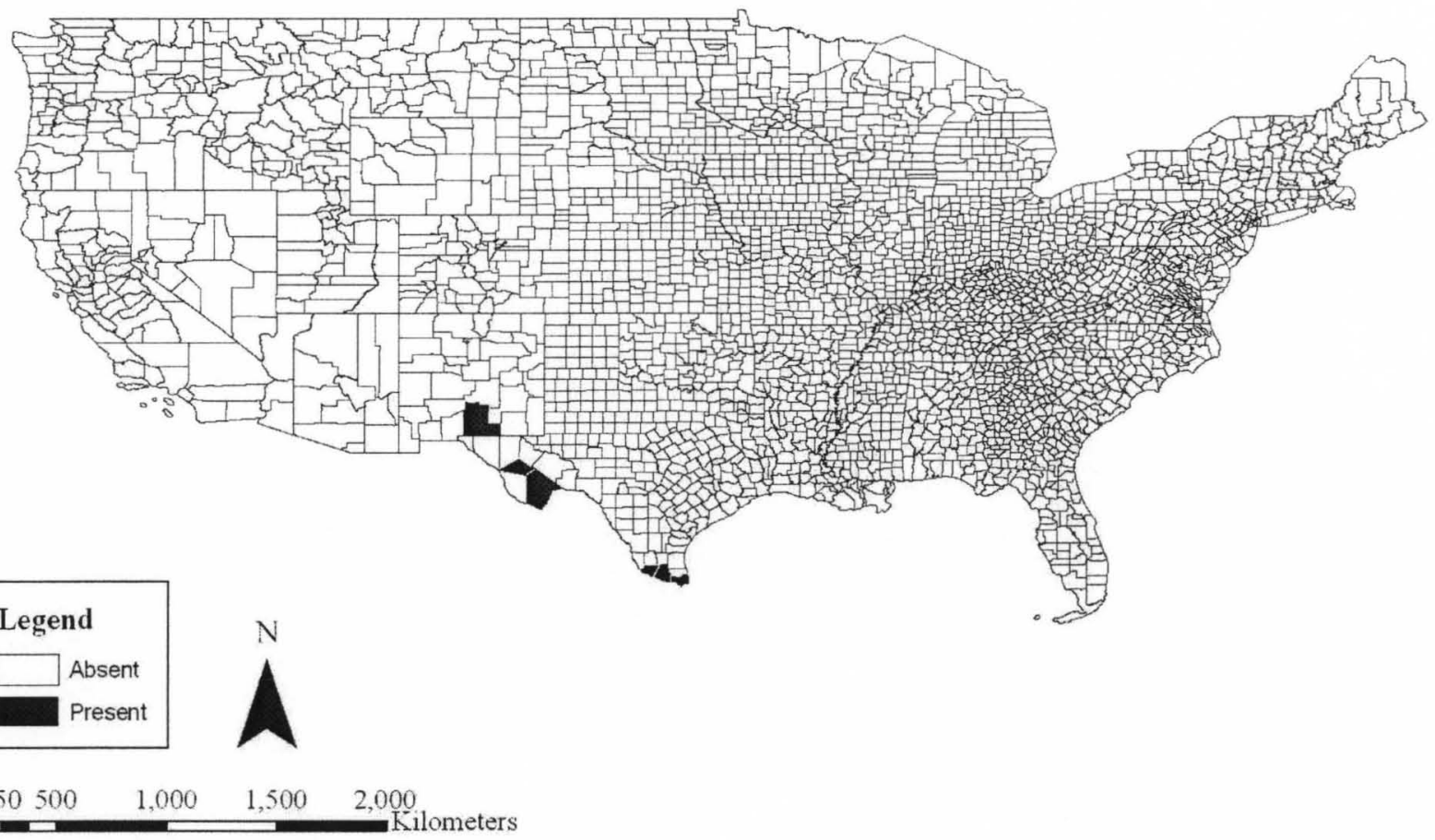




\section{BIOGEOGRAPHIC RANGE BY COUNTY IN THE CONTIGUOUS STATES}

Gastrocopta rupicola

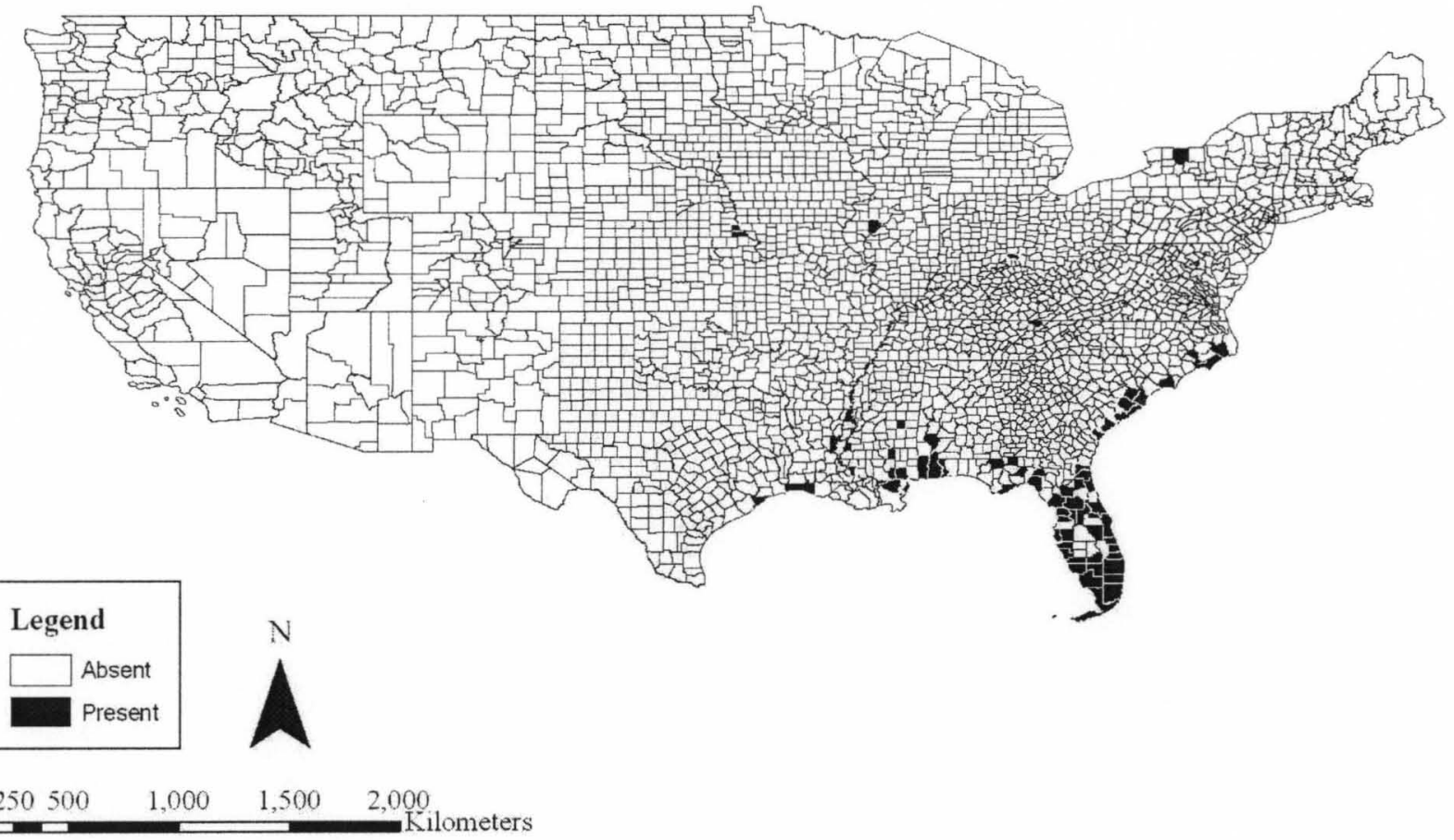




\section{BIOGEOGRAPHIC RANGE BY COUNTY IN THE CONTIGUOUS STATES}

Gastrocopta tappaniana

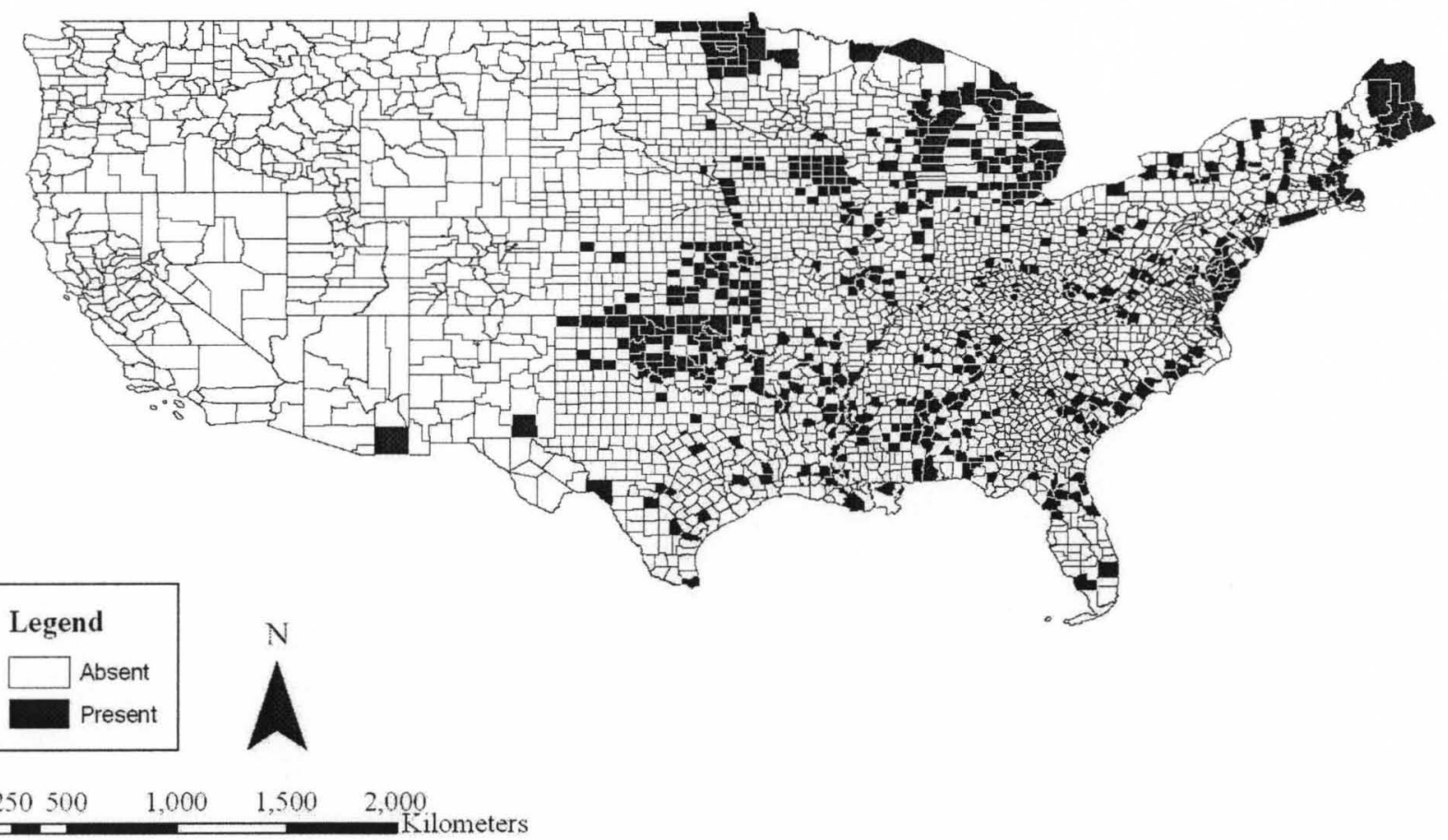


BIOGEOGRAPHIC RANGE BY COUNTY IN THE CONTIGUOUS STATES

Gyraulus circumstriatus

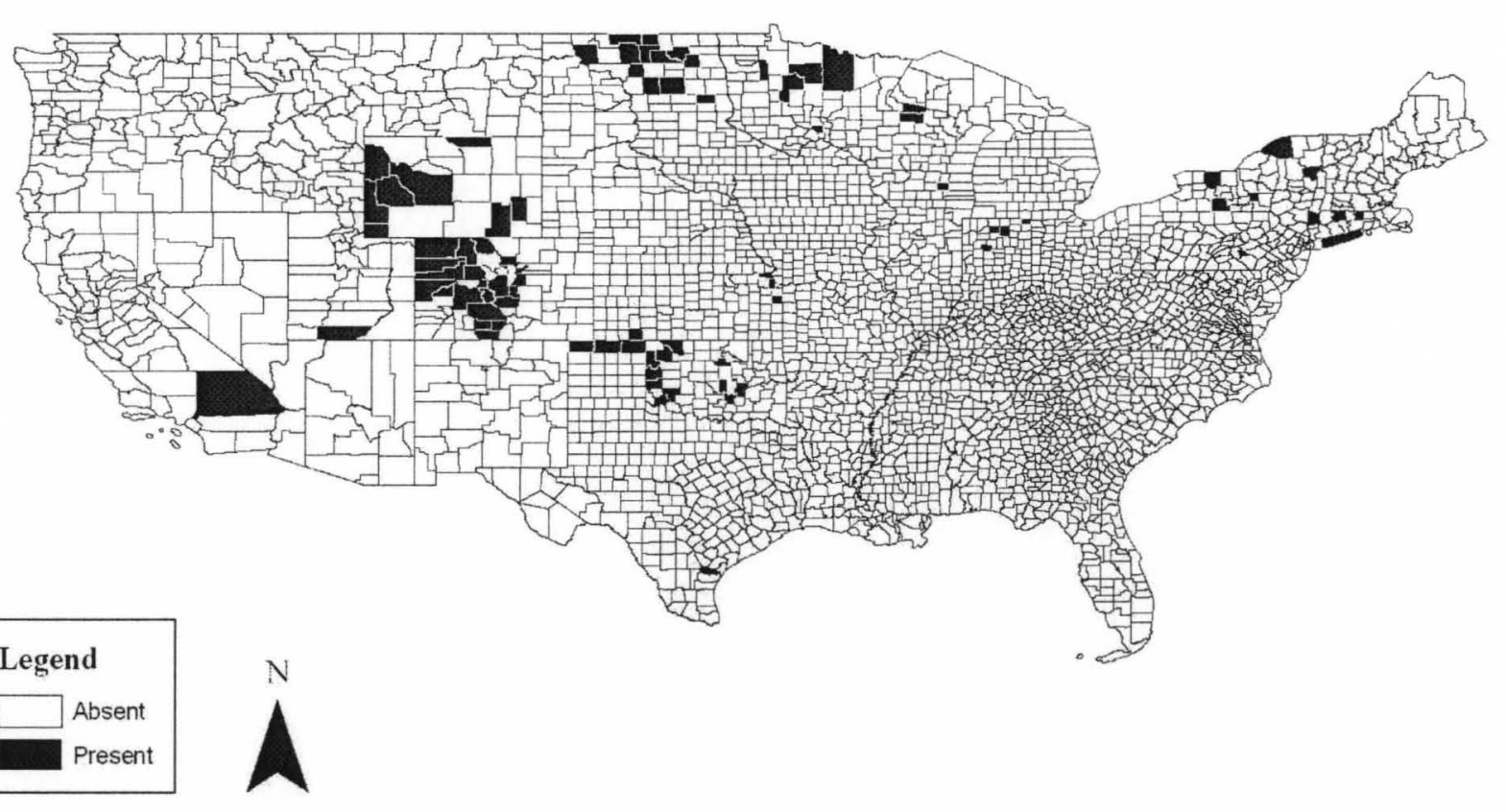

\begin{tabular}{llll}
0 & $250 \quad 500 \quad 1,000$ & 1,500 & 2,000 \\
\hline
\end{tabular} 
BIOGEOGRAPHIC RANGE BY COUNTY IN THE CONTIGUOUS STATES

Gyraulus deflectus

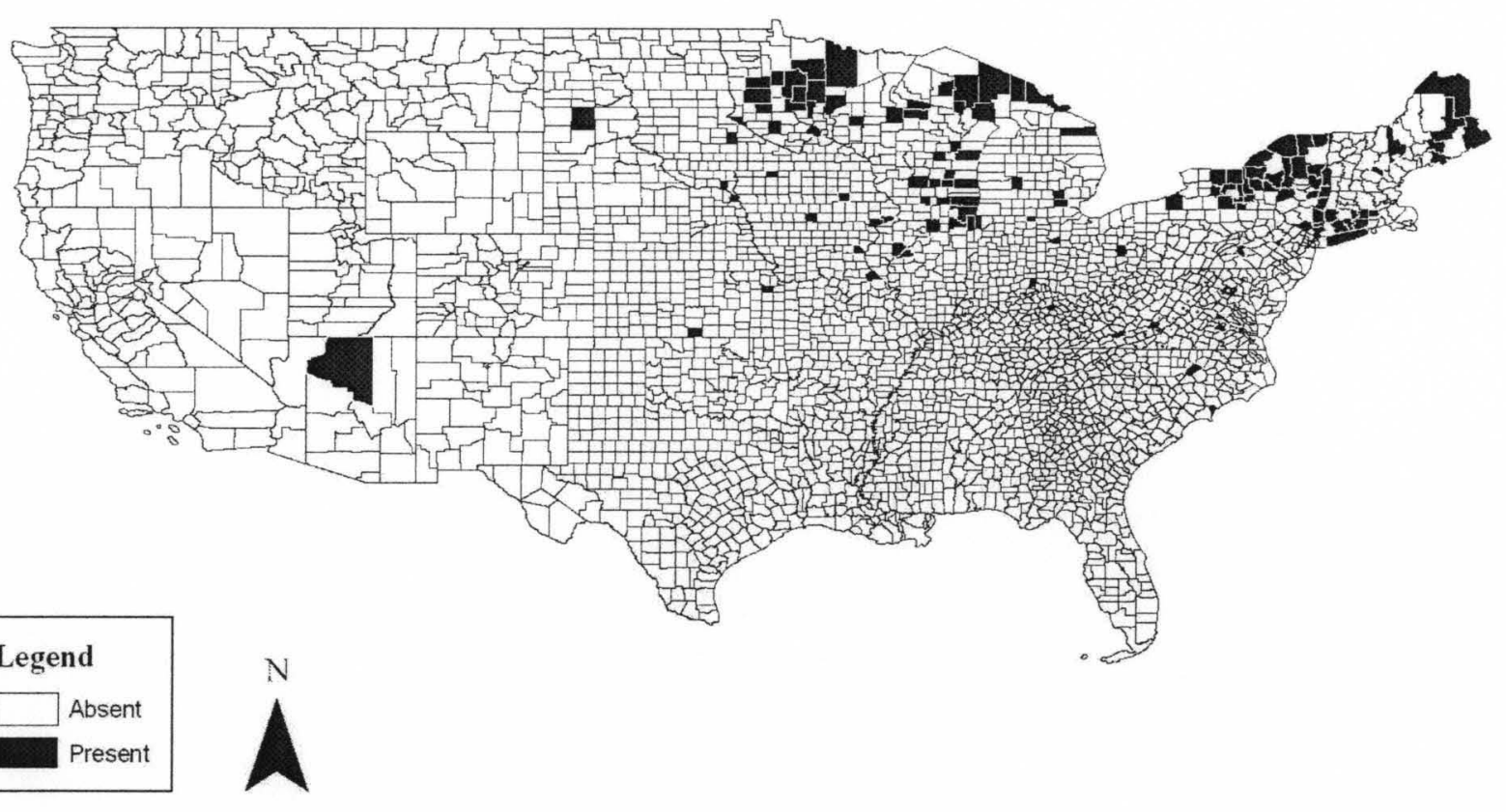

\begin{tabular}{llll}
250 & $500 \quad 1,000$ & 1,500 & 2,000 \\
\hline
\end{tabular} 
BIOGEOGRAPHIC RANGE BY COUNTY IN THE CONTIGUOUS STATES

Gyraulus parvus

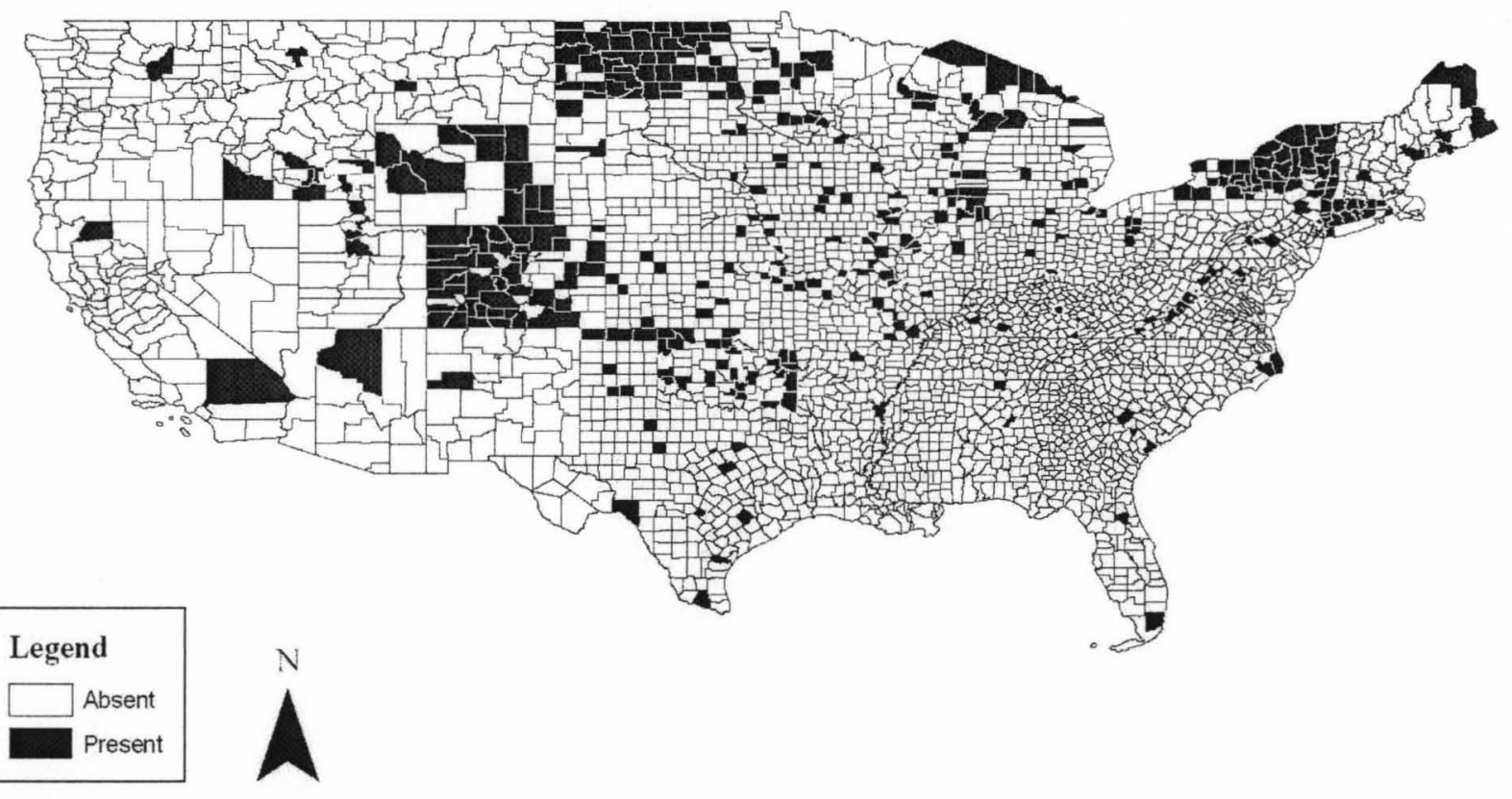

250500

$1,000 \quad 1,500 \quad 2,000$

Kilometers 


\section{BIOGEOGRAPHIC RANGE BY COUNTY IN ALASKA}

Gyraulus parvus

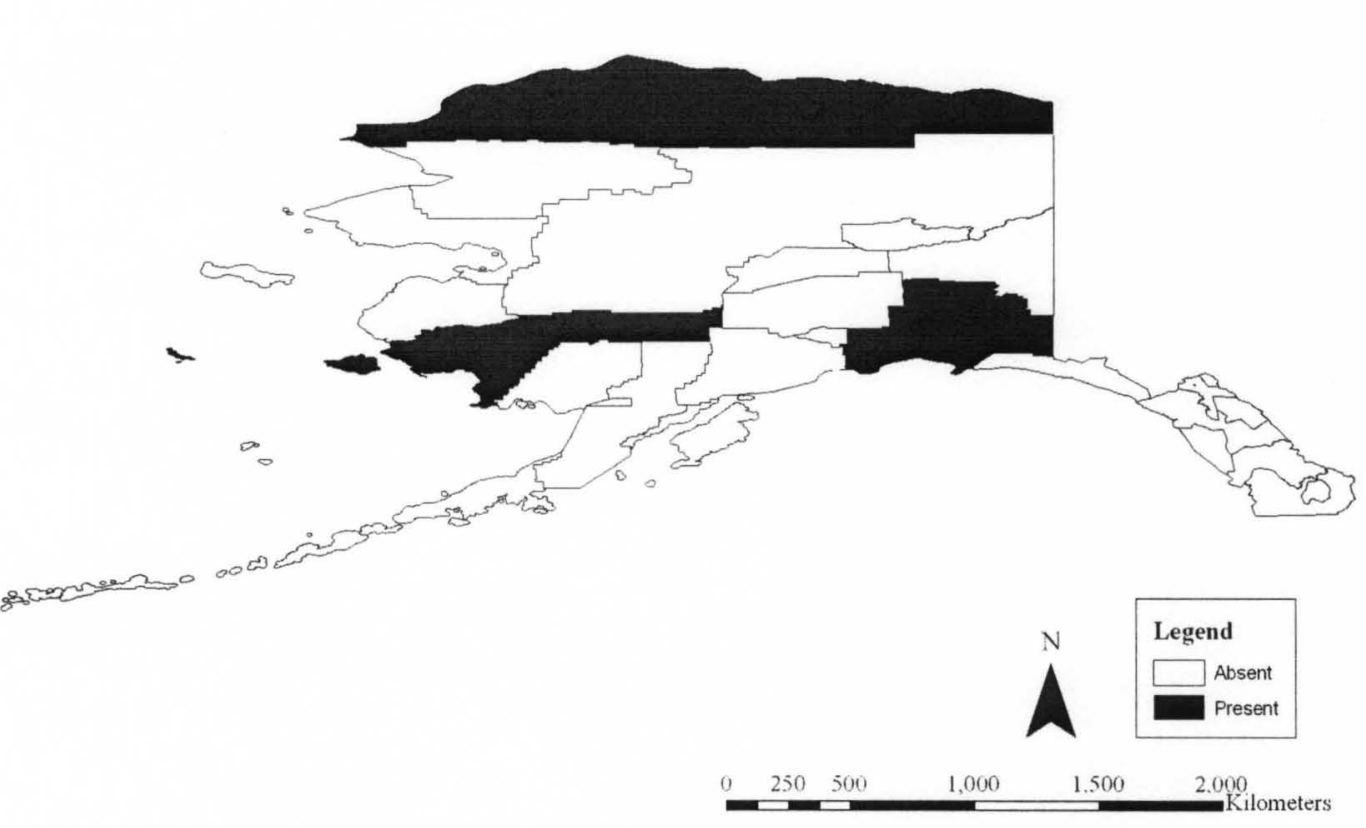


BIOGEOGRAPHIC RANGE BY COUNTY IN THE CONTIGUOUS STATES

Hawaiia minuscula

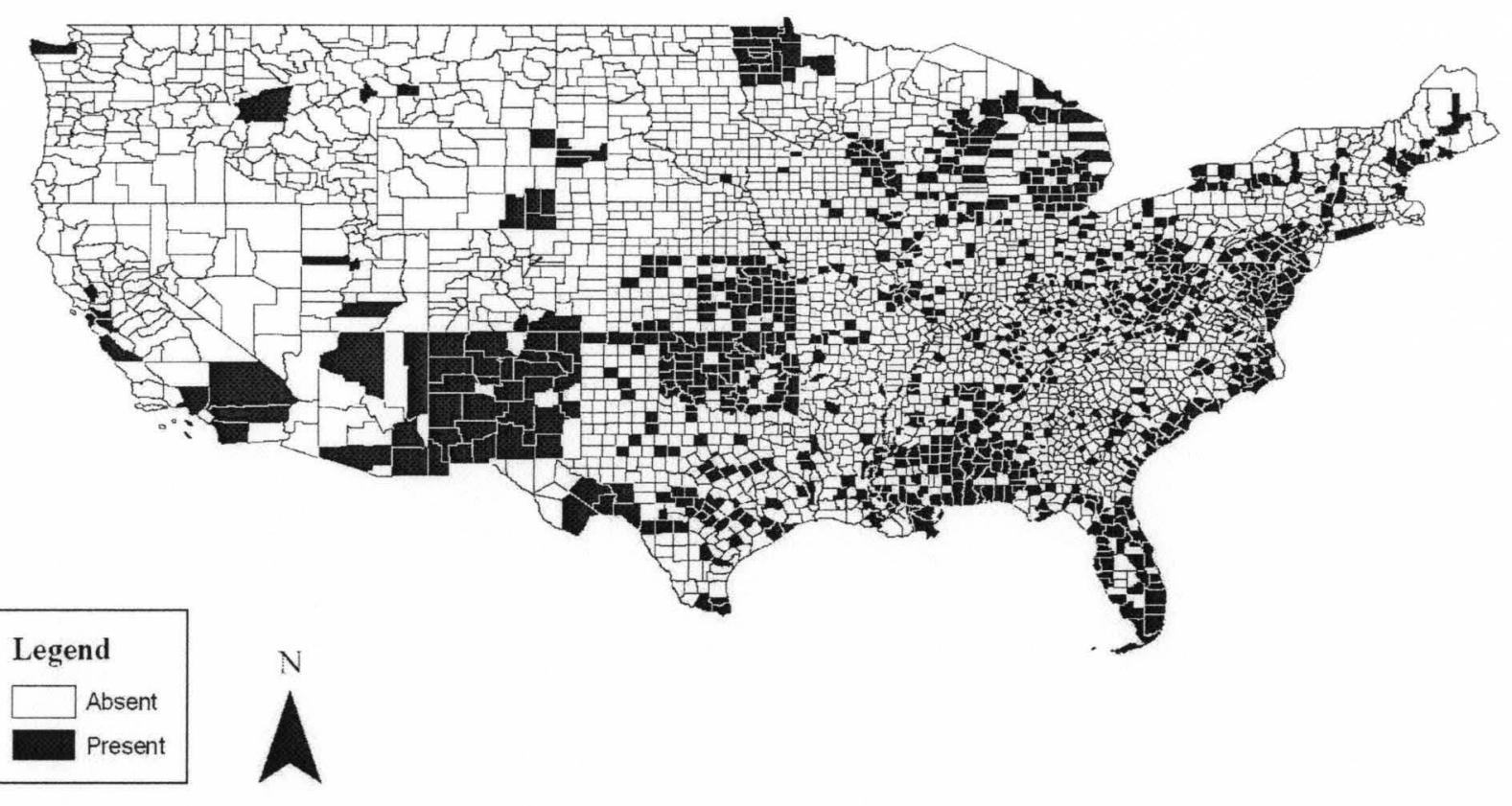

\begin{tabular}{lllll}
0 & $250500 \quad 1,000$ & 1,500 & 2,000 \\
\hline
\end{tabular} 
BIOGEOGRAPHIC RANGE BY COUNTY IN HAWAII

Hawaiia minuscula

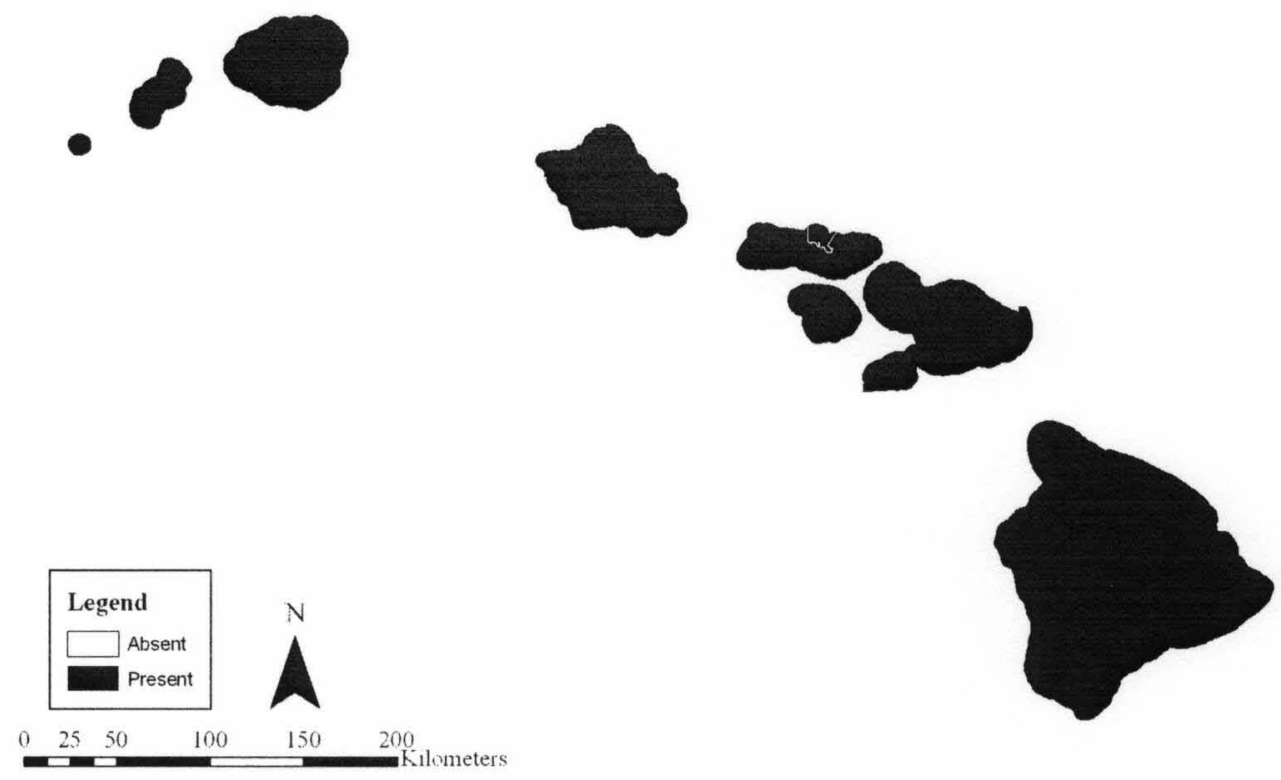


BIOGEOGRAPHIC RANGE BY COUNTY IN THE CONTIGUOUS STATES

Helicodiscus parallelus

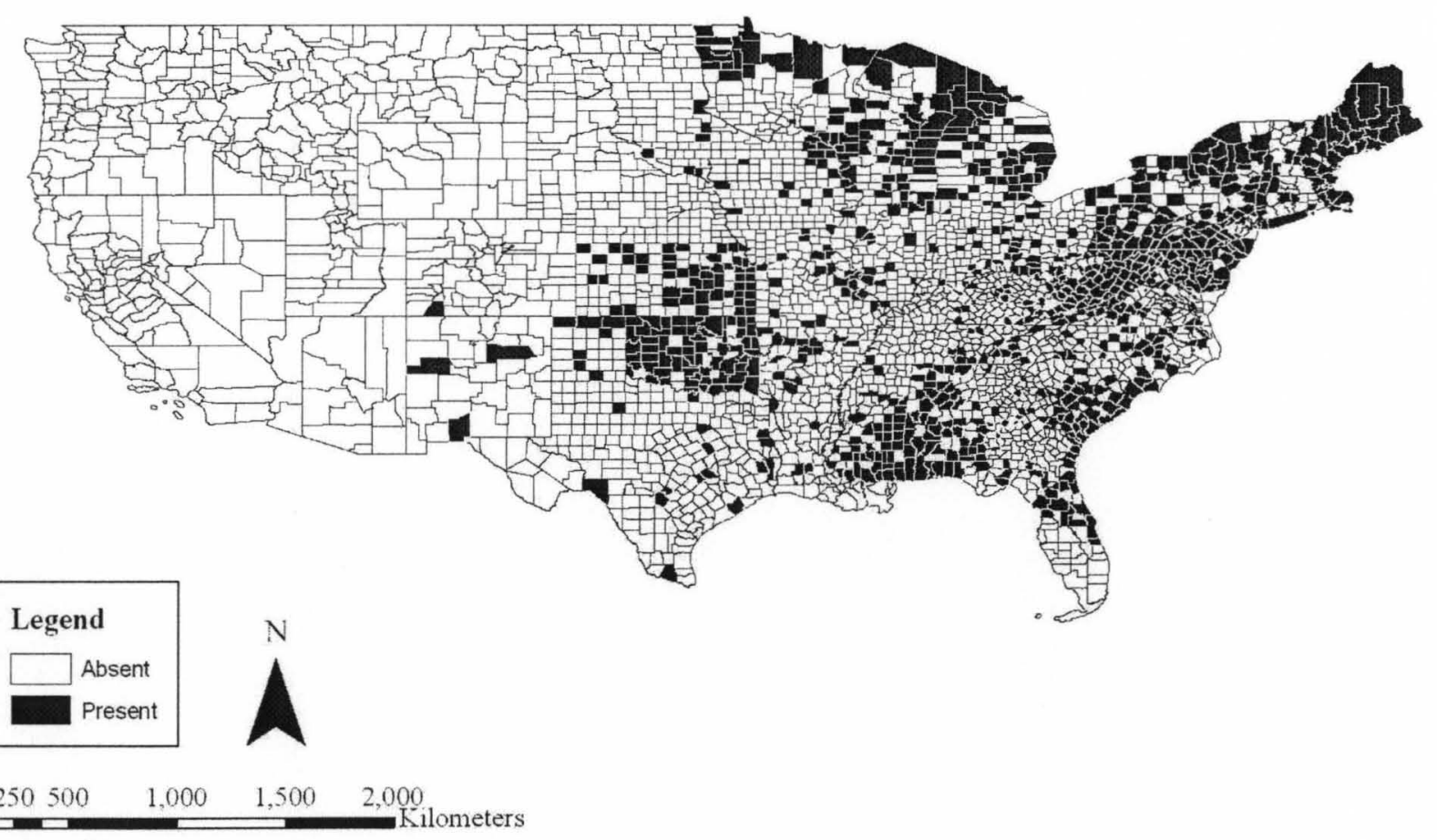


BIOGEOGRAPHIC RANGE BY COUNTY IN THE CONTIGUOUS STATES Helicodiscus singleyanus

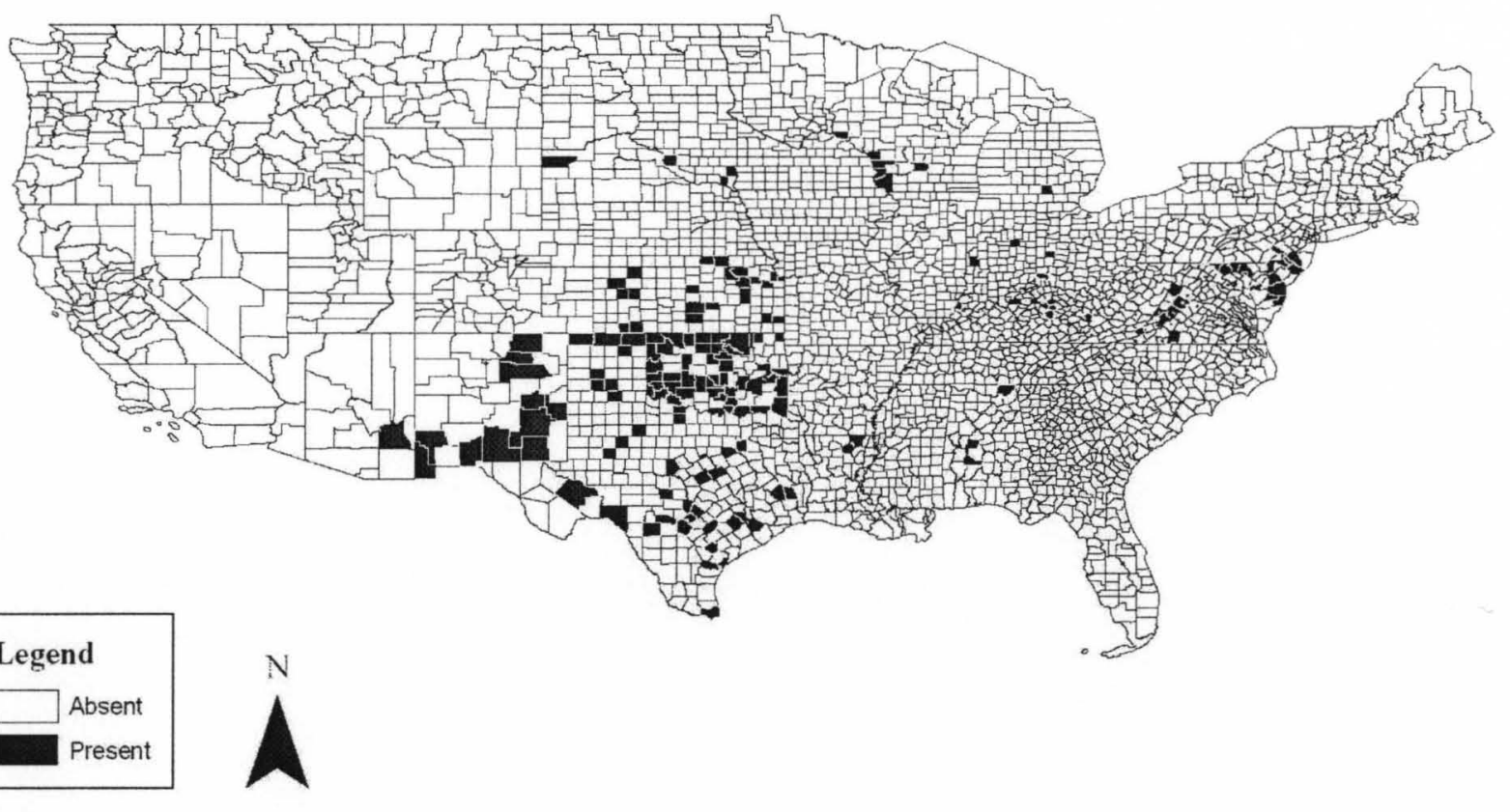

\begin{tabular}{llll}
$0 \quad 250 \quad 500 \quad 1,000 \quad 1,500 \quad 2,000$ \\
\hline
\end{tabular} 
BIOGEOGRAPHIC RANGE BY COUNTY IN THE CONTIGUOUS STATES

Laevapex fuscus

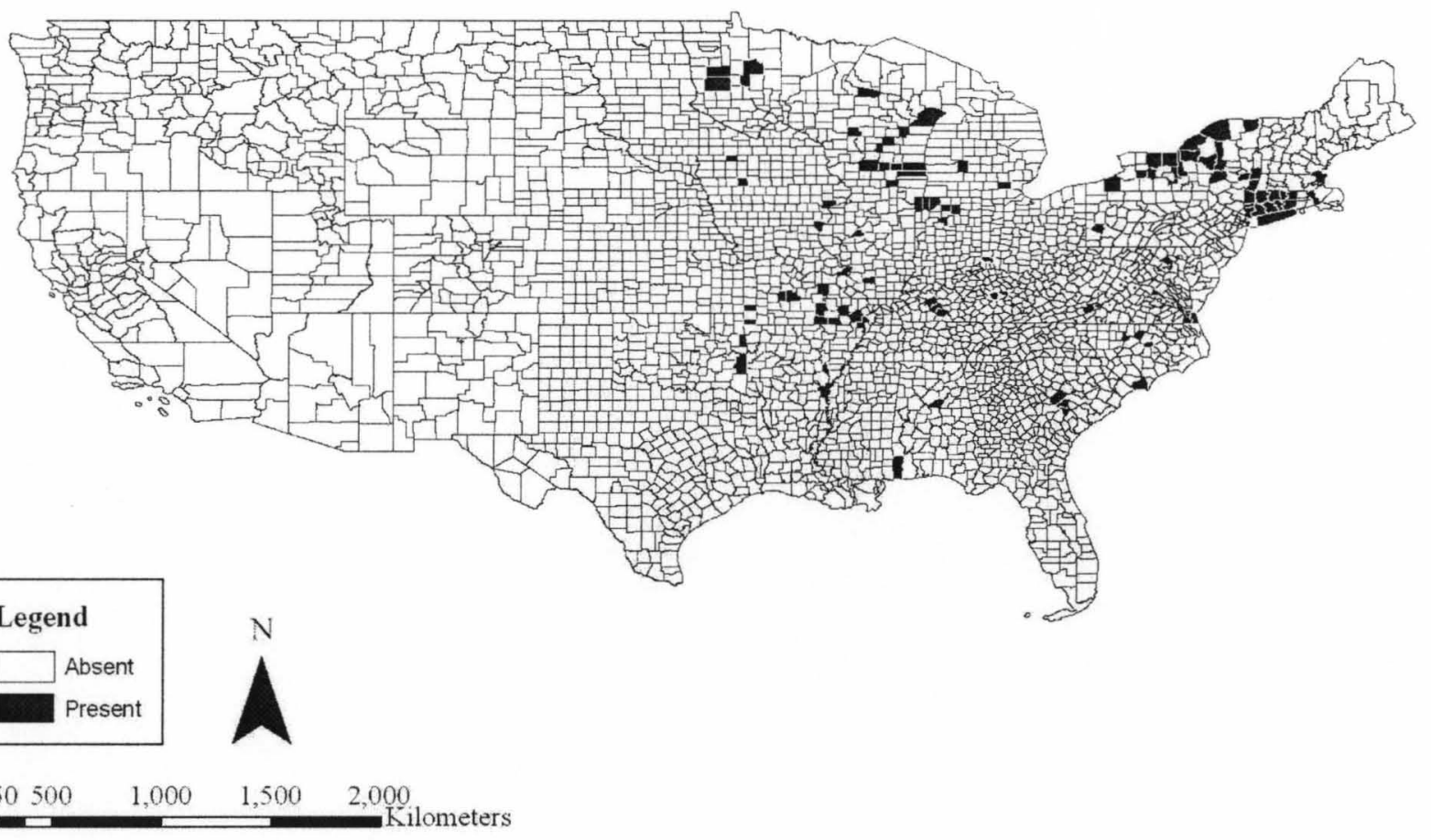


BIOGEOGRAPHIC RANGE BY COUNTY IN THE CONTIGUOUS STATES

Nesovitrea electrina

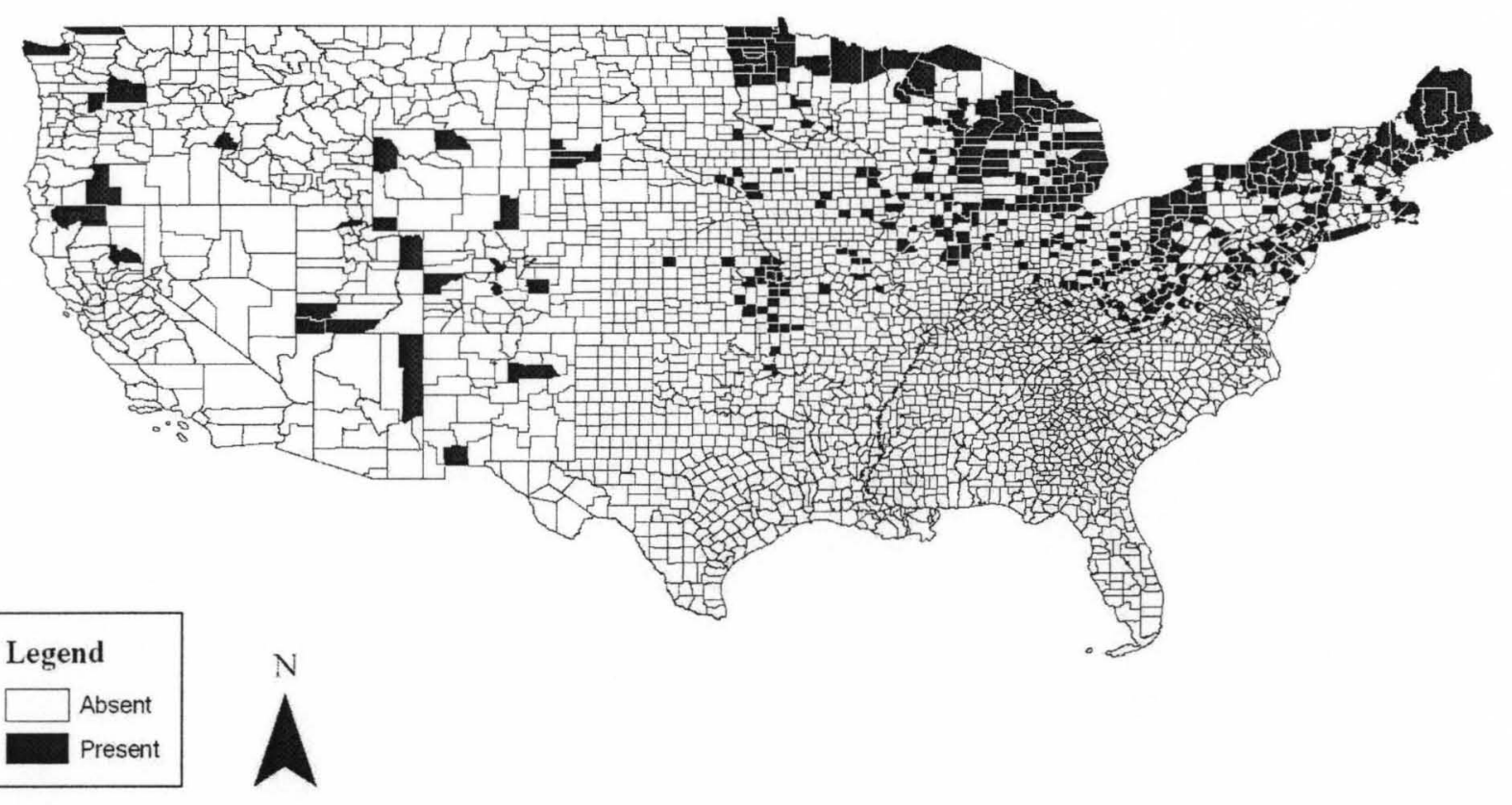

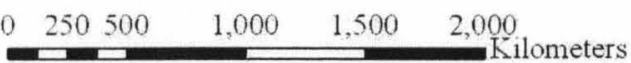


BIOGEOGRAPHIC RANGE BY COUNTY IN THE CONTIGUOUS STATES

Physidae

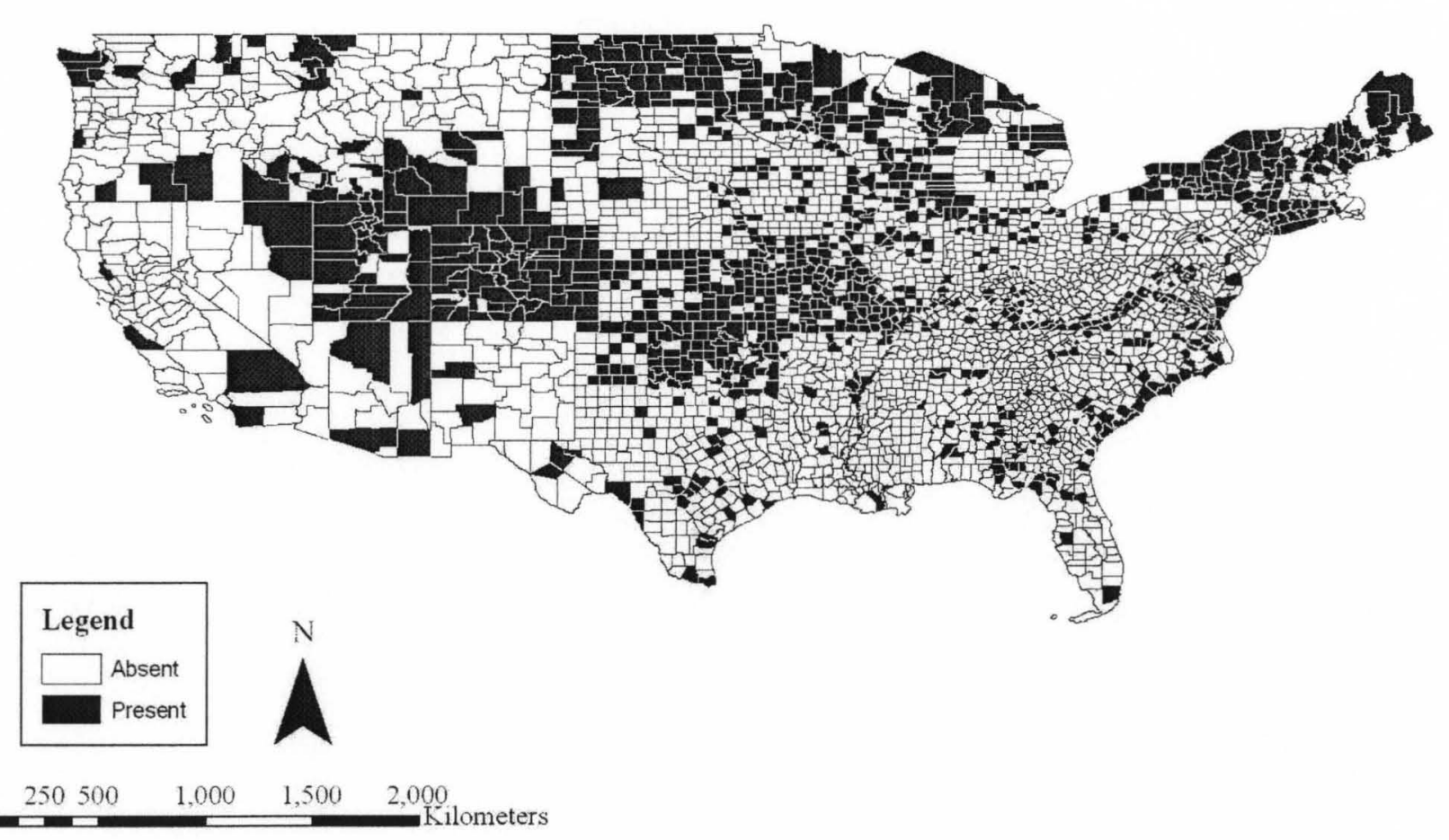


BIOGEOGRAPHIC RANGE BY COUNTY IN ALASKA

Physidae

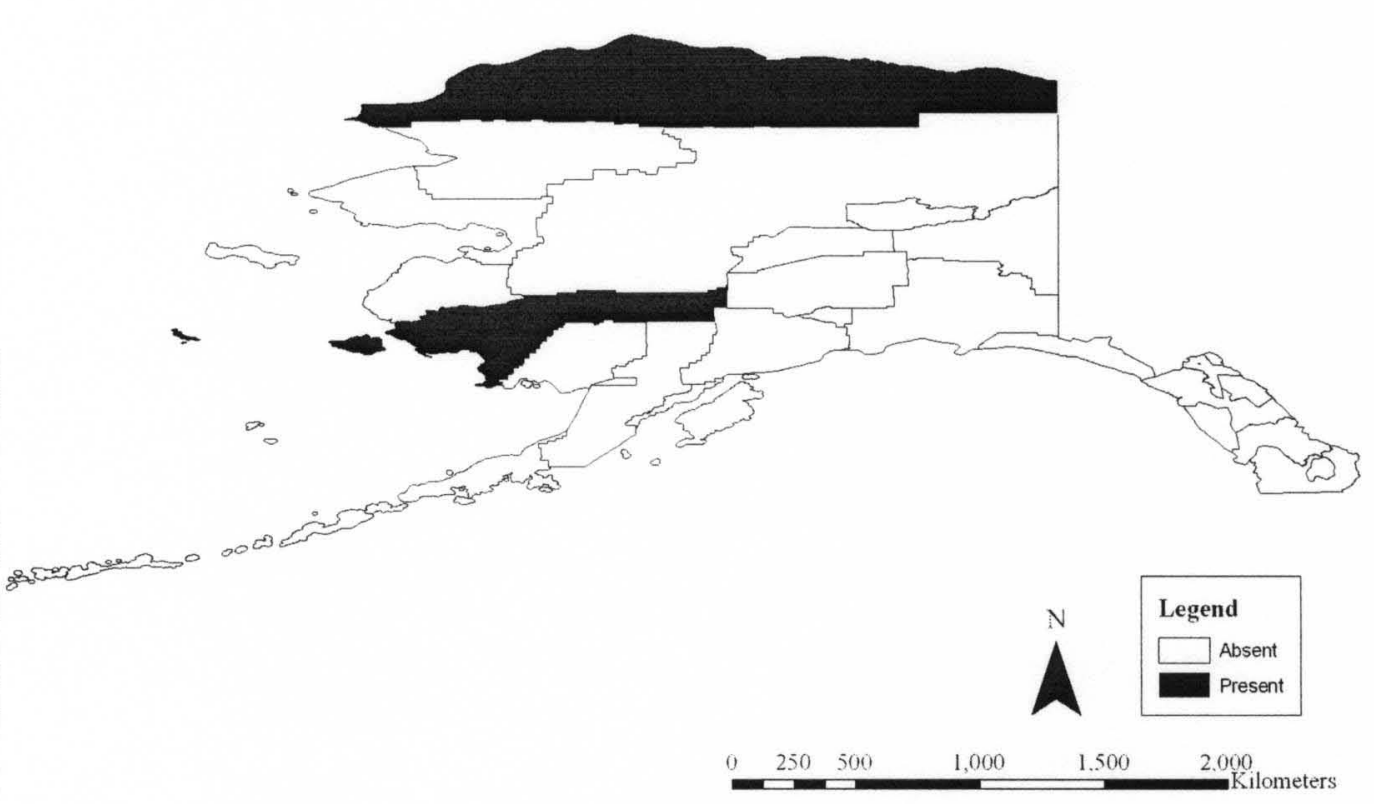

BIOGEOGRAPHIC RANGE BY COUNTY IN HAWAII

Physidae

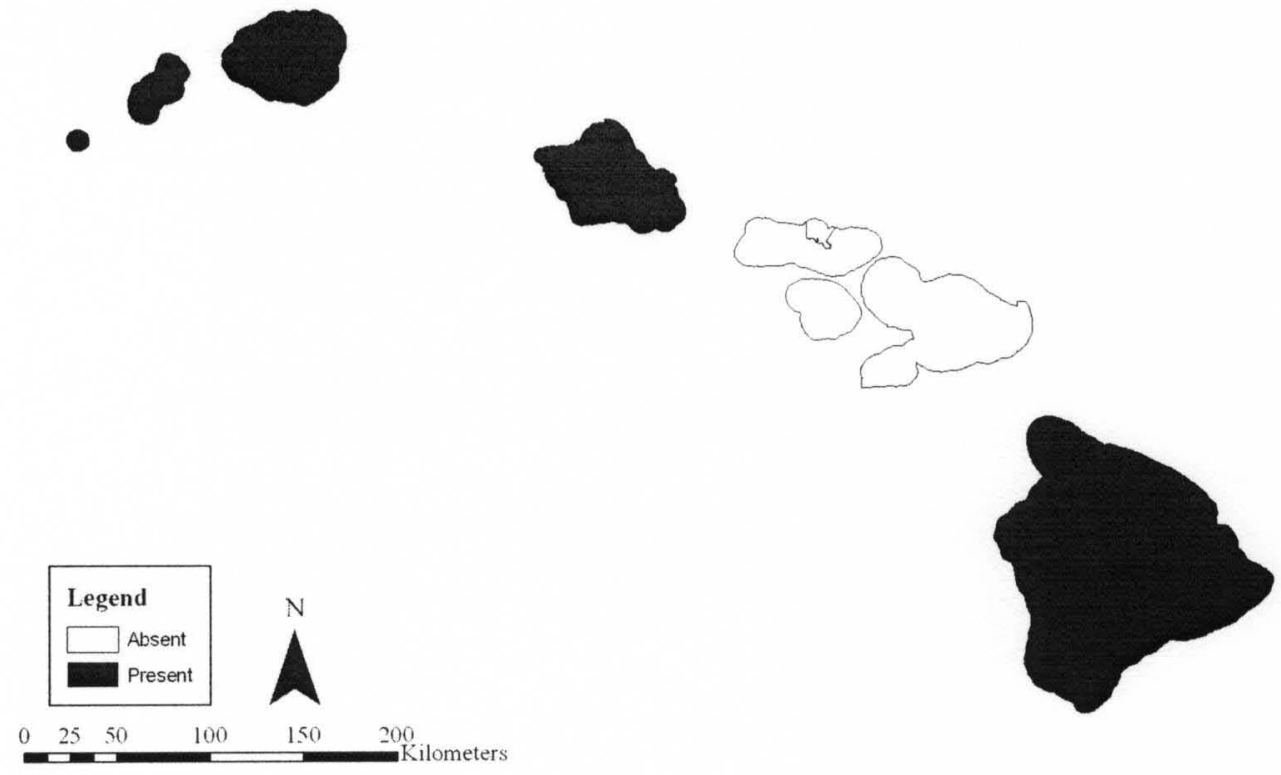


BIOGEOGRAPHIC RANGE BY COUNTY IN THE CONTIGUOUS STATES

Pisidiidae

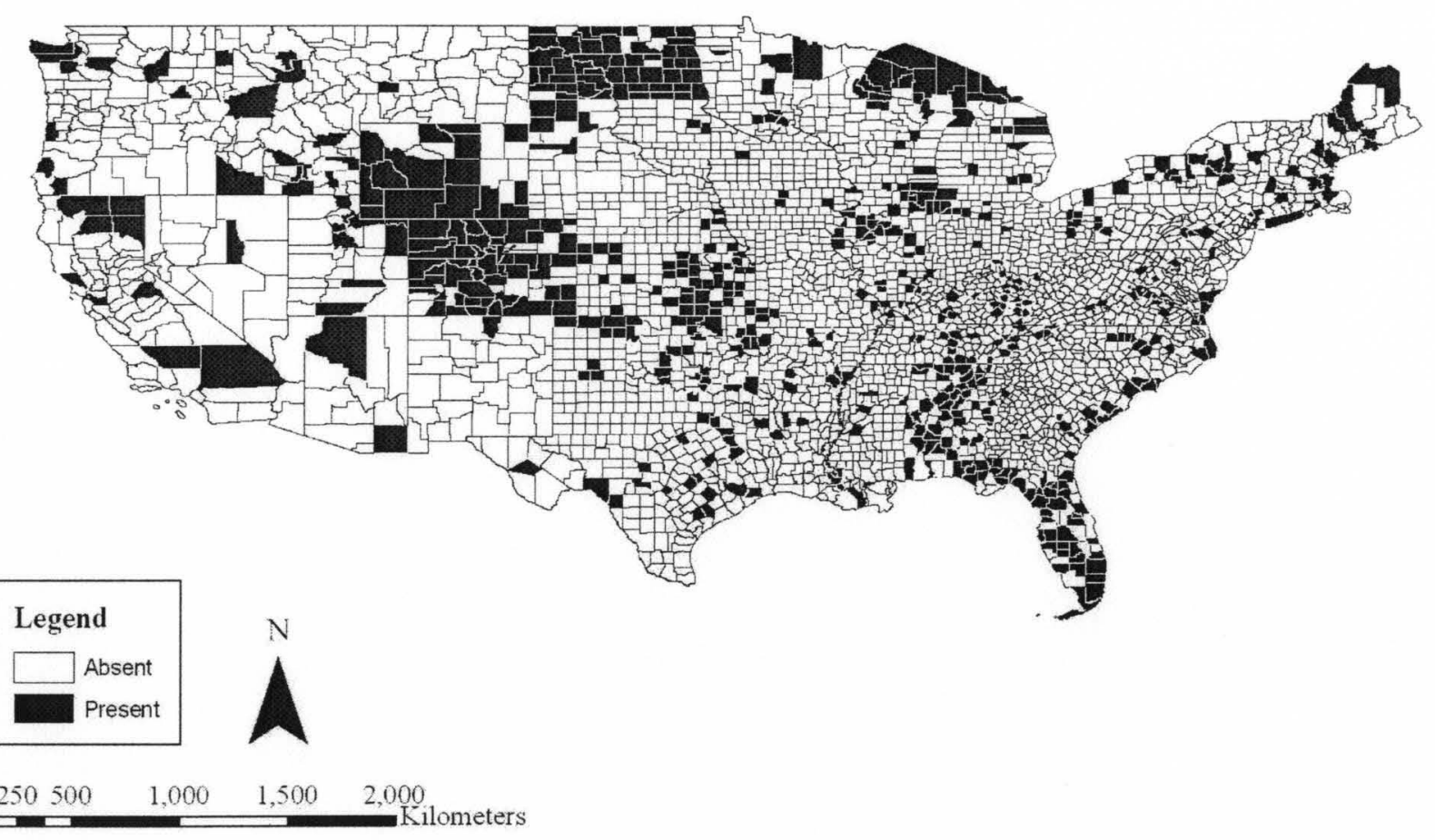


BIOGEOGRAPHIC RANGE BY COUNTY IN ALASKA

Pisidiidae

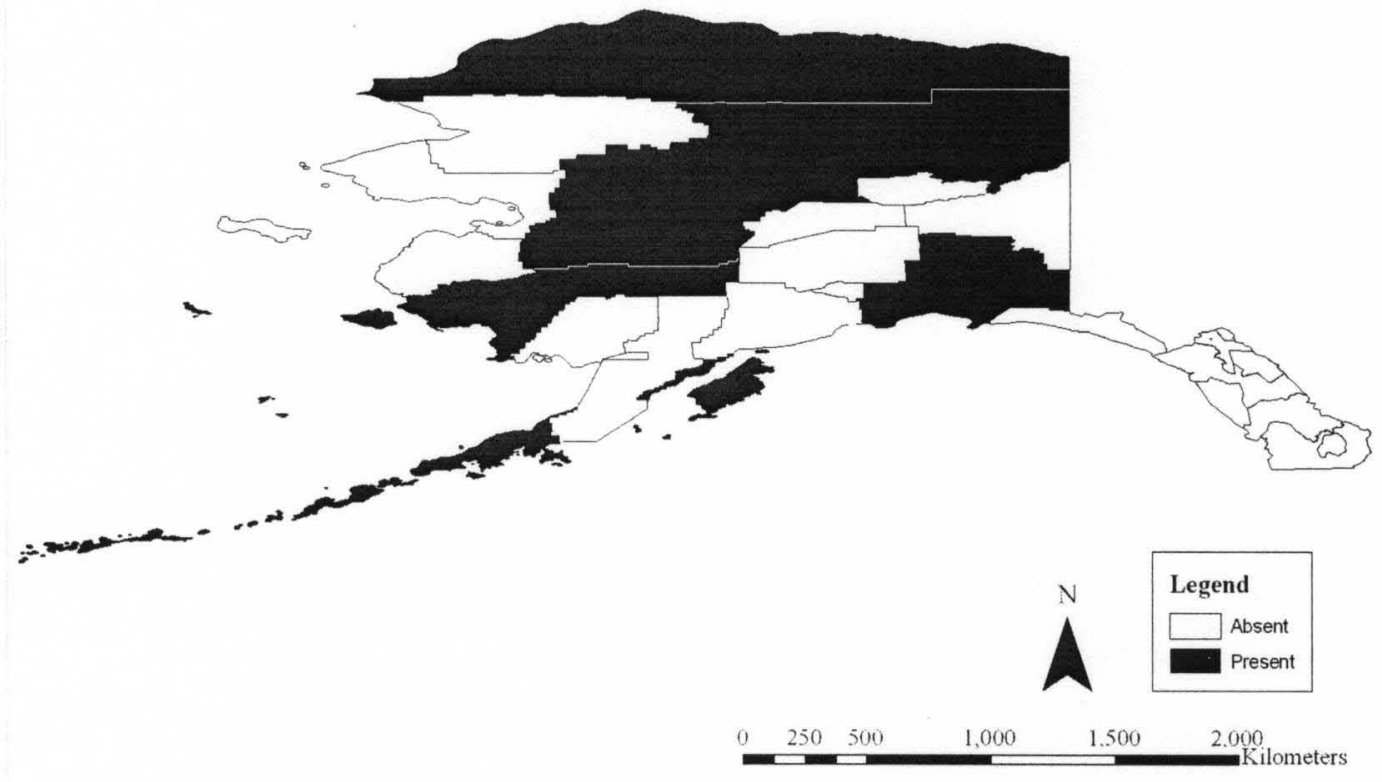

BIOGEOGRAPHIC RANGE BY COUNTY IN HAWAII

Pisidiidae

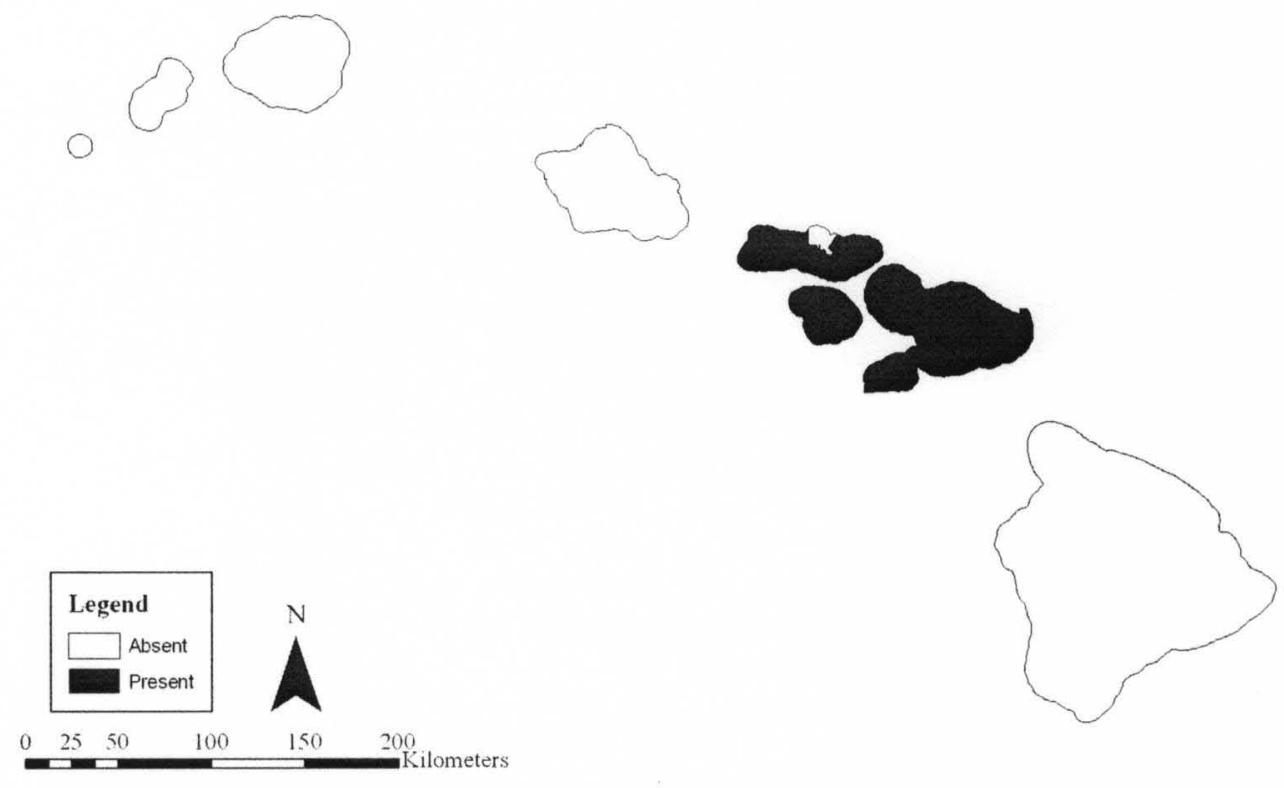


BIOGEOGRAPHIC RANGE BY COUNTY IN THE CONTIGUOUS STATES

Planorbella trivolvis

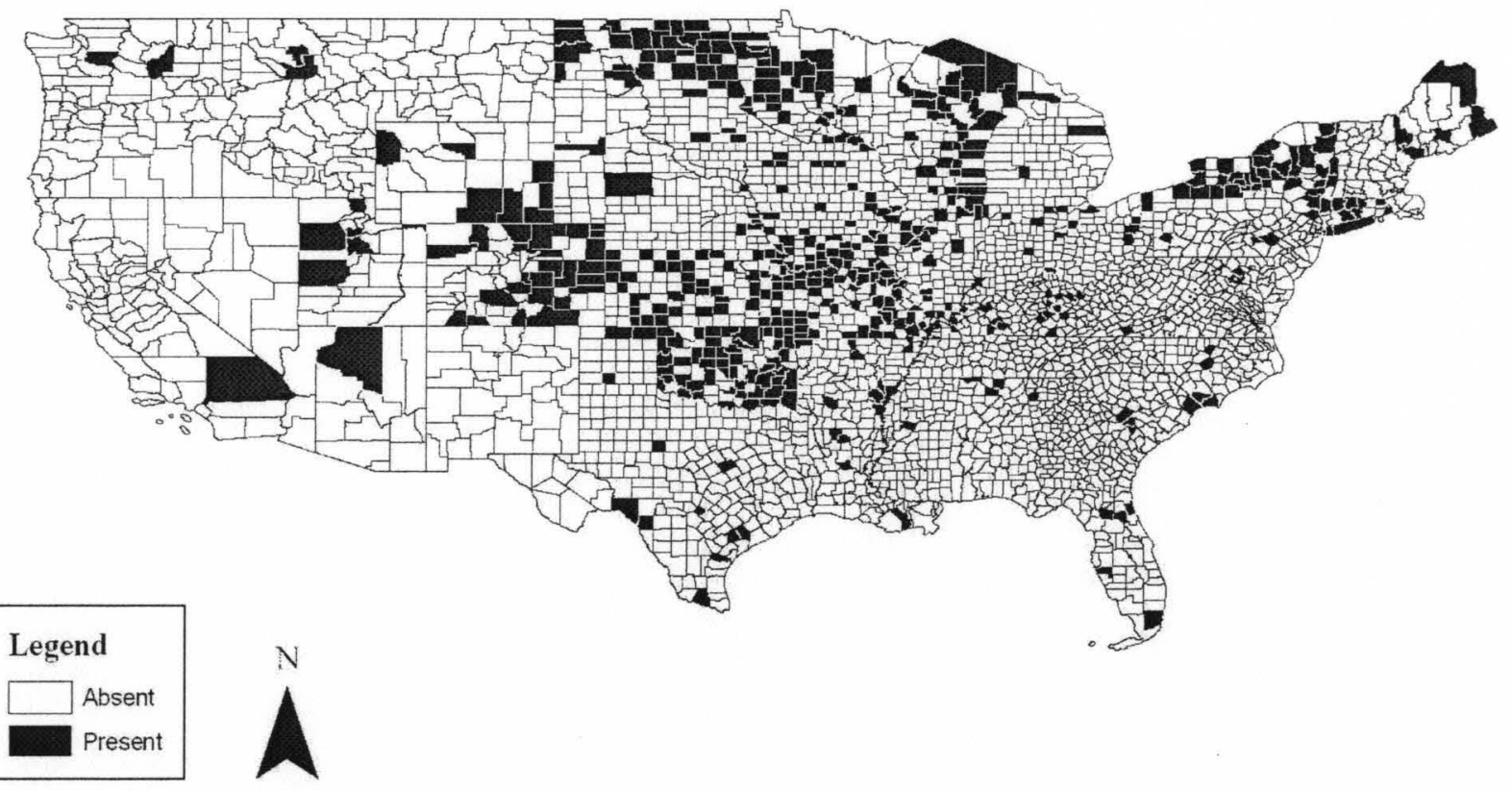

0 250500

$1,000 \quad 1,500 \quad 2,000$

Kilometers 


\section{BIOGEOGRAPHIC RANGE BY COUNTY IN ALASKA}

Planorbella trivolvis

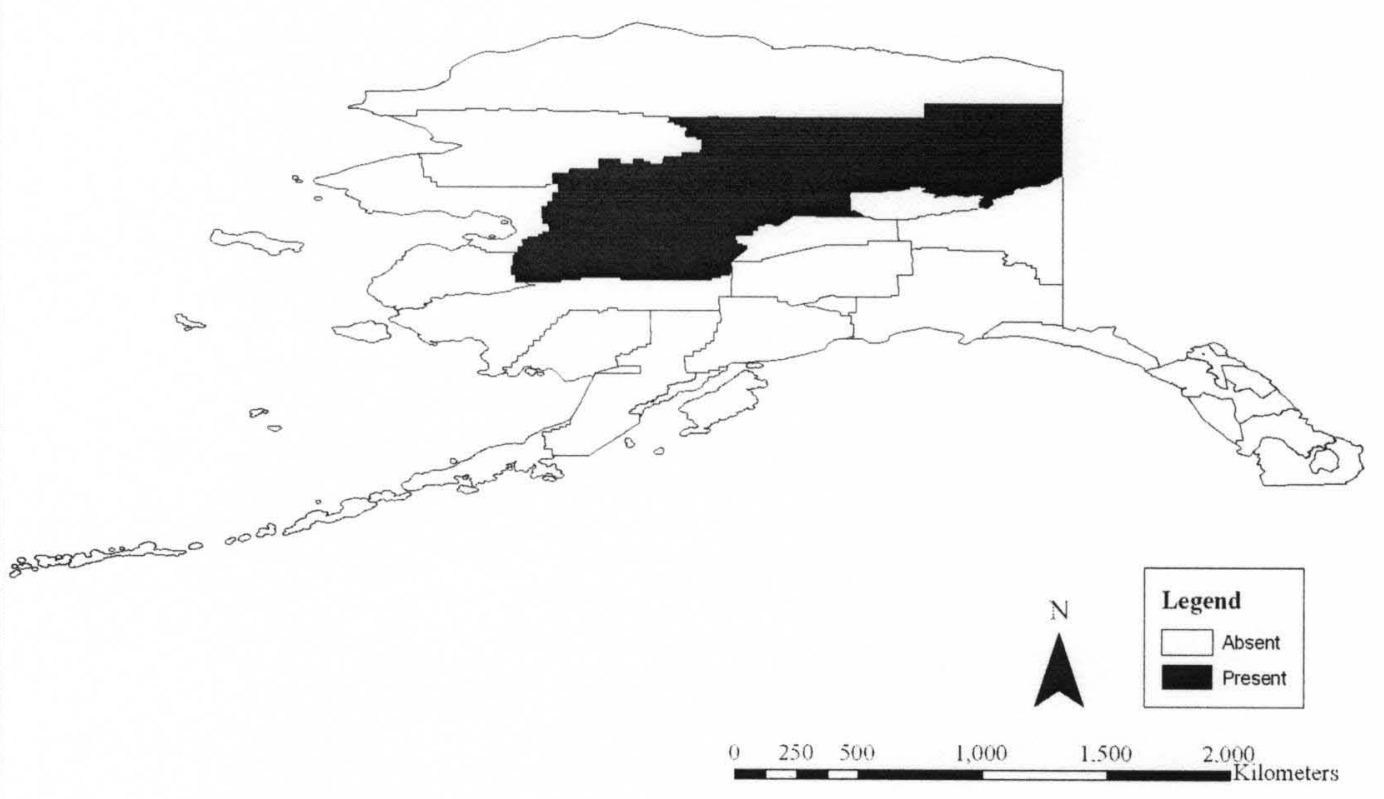




\section{BIOGEOGRAPHIC RANGE BY COUNTY IN THE CONTIGUOUS STATES}

Planorbula armigera

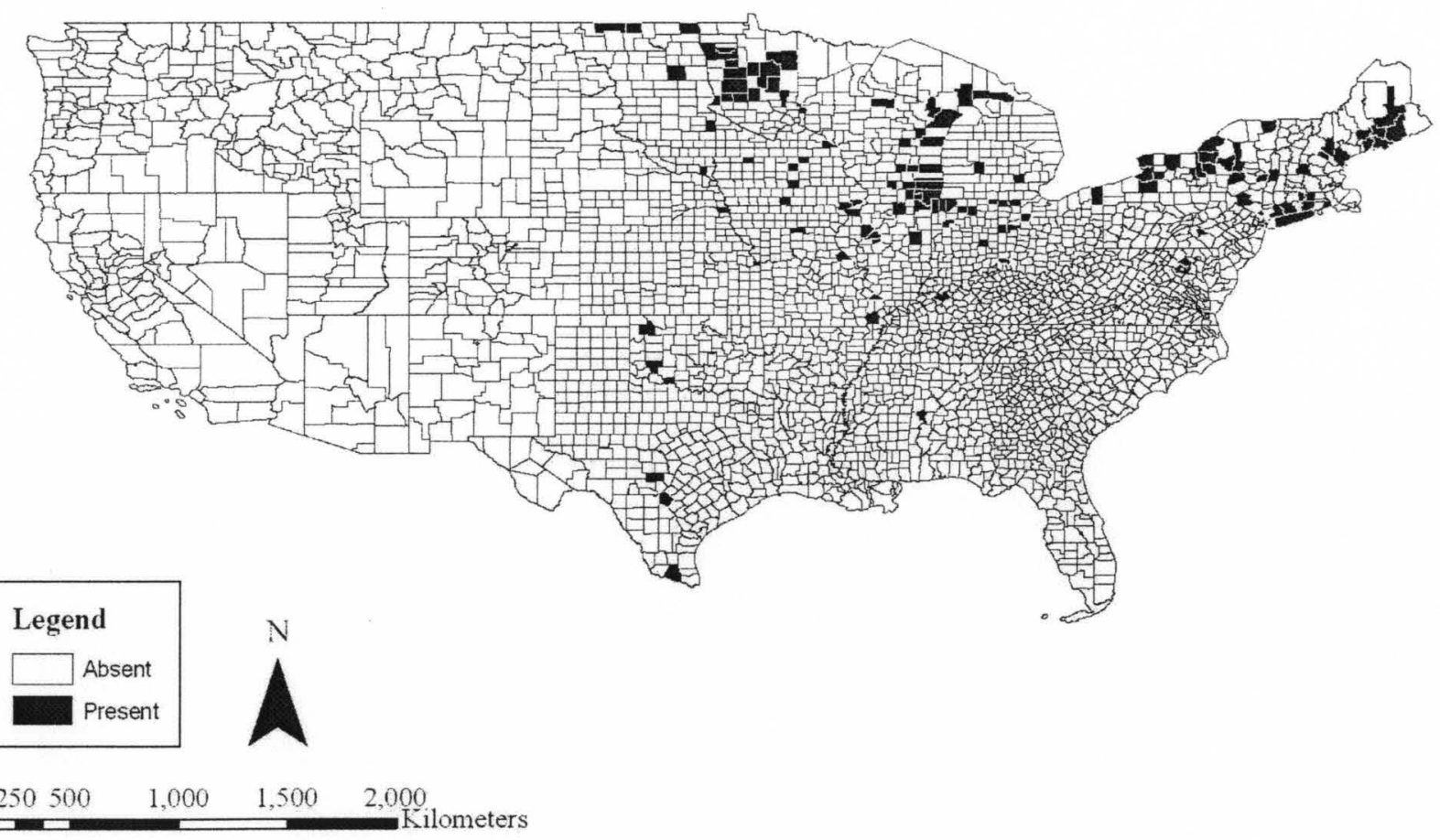




\section{BIOGEOGRAPHIC RANGE BY COUNTY IN THE CONTIGUOUS STATES}

Promenetus exacuous

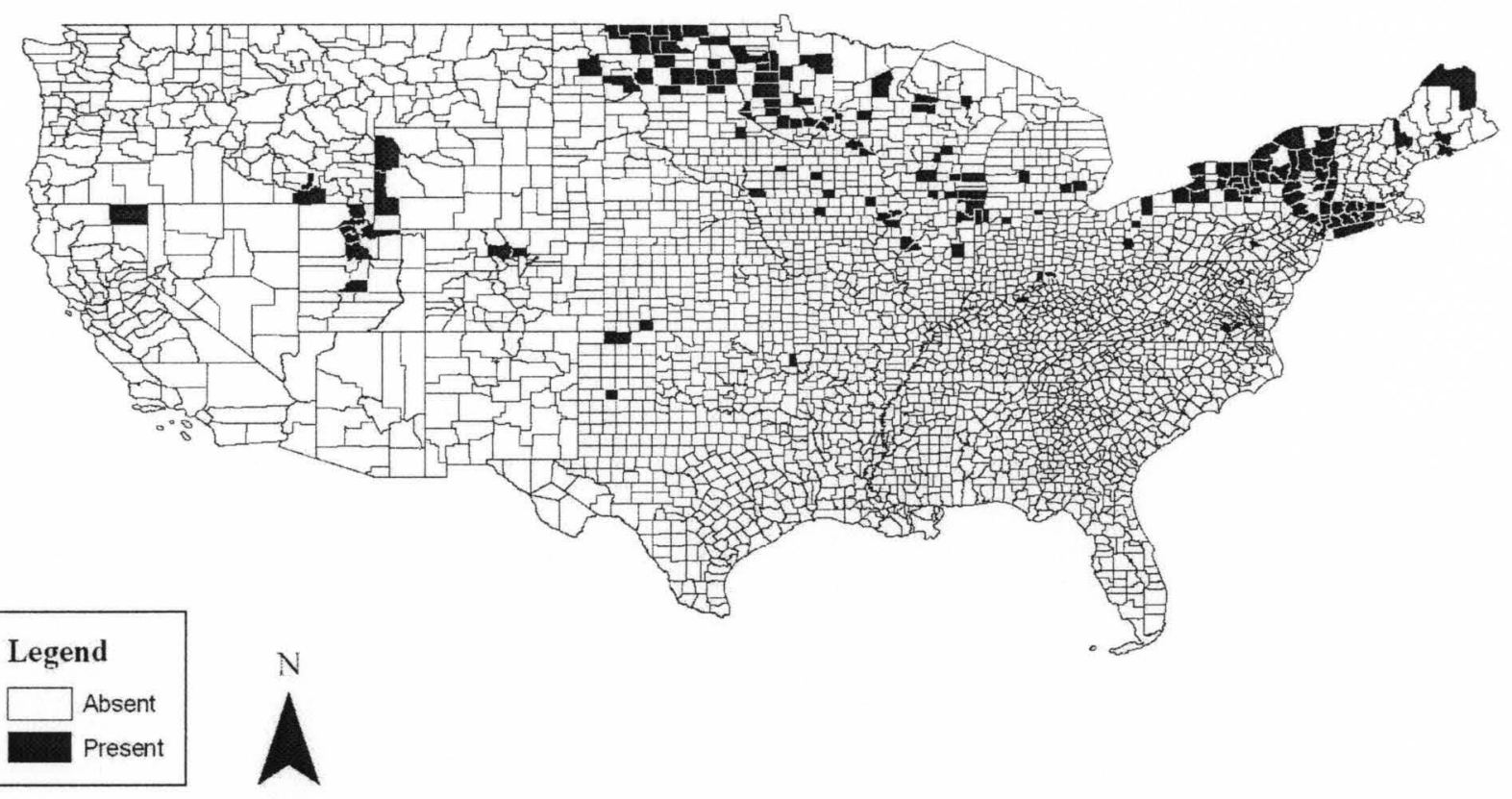

0 250500

$1,000 \quad 1,500 \quad 2,000$

Kilometers 
BIOGEOGRAPHIC RANGE BY COUNTY IN THE CONTIGUOUS STATES

Punctum minutissimum

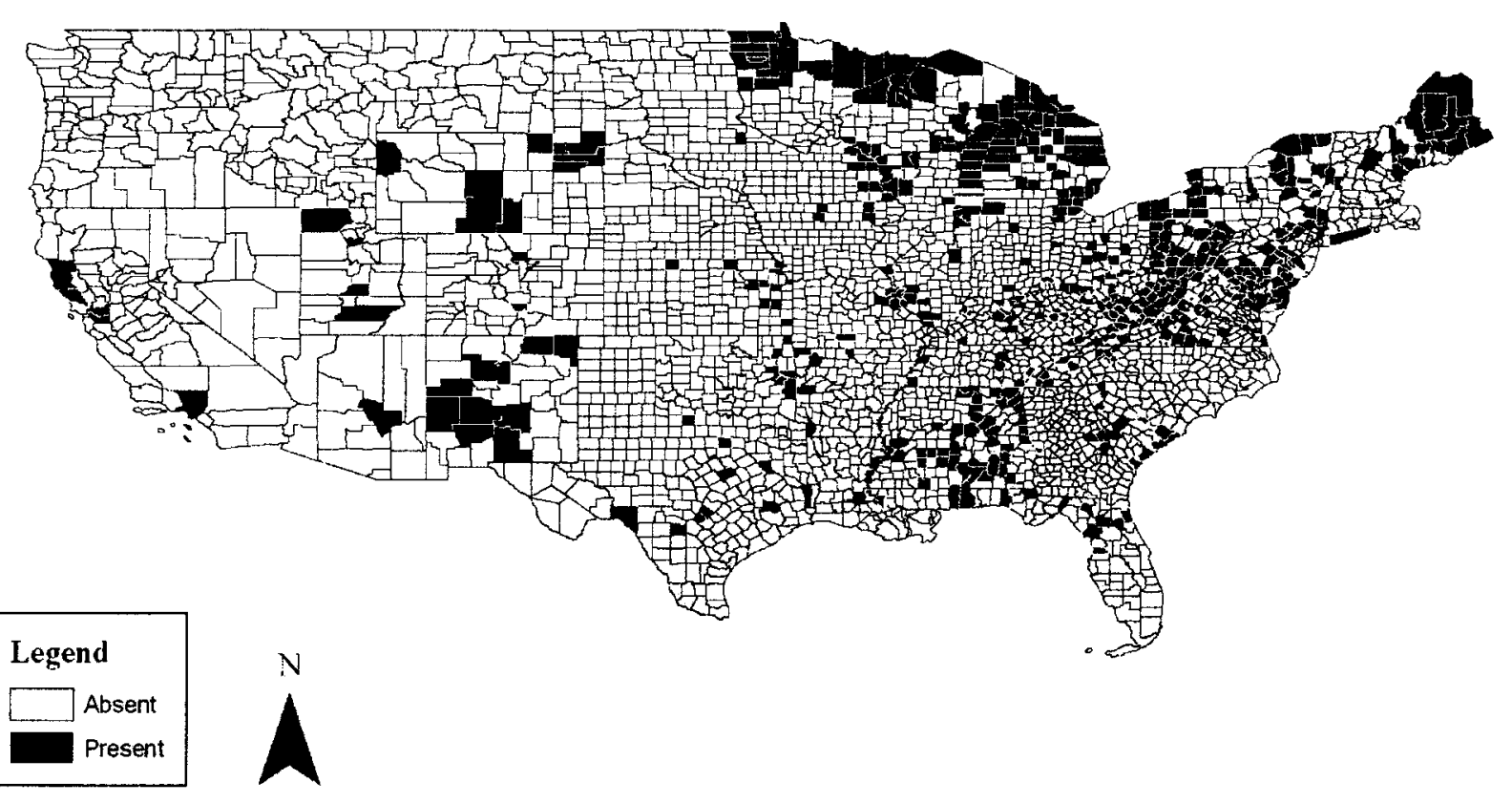

\begin{tabular}{lllll}
$0 \quad 250500 \quad 1,000 \quad 1,500 \quad 2,000$ \\
\hline
\end{tabular} 


\section{BIOGEOGRAPHIC RANGE BY COUNTY IN THE CONTIGUOUS STATES}

Pupilla blandi

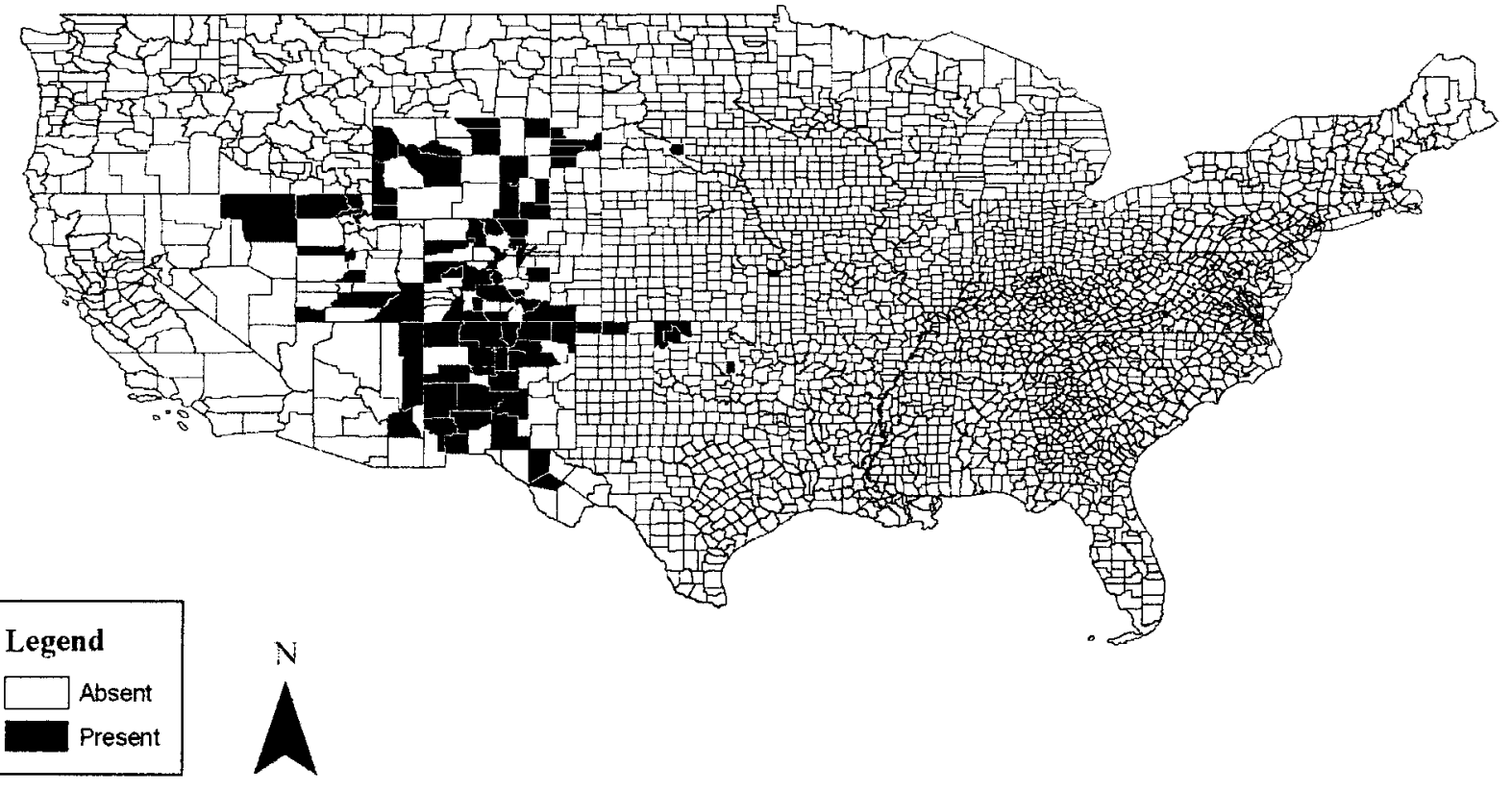

\begin{tabular}{llll}
$250500 \quad 1,000 \quad 1,500$ & 2,000 \\
\hline
\end{tabular} 


\section{BIOGEOGRAPHIC RANGE BY COUNTY IN THE CONTIGUOUS STATES}

Pupilla muscorum

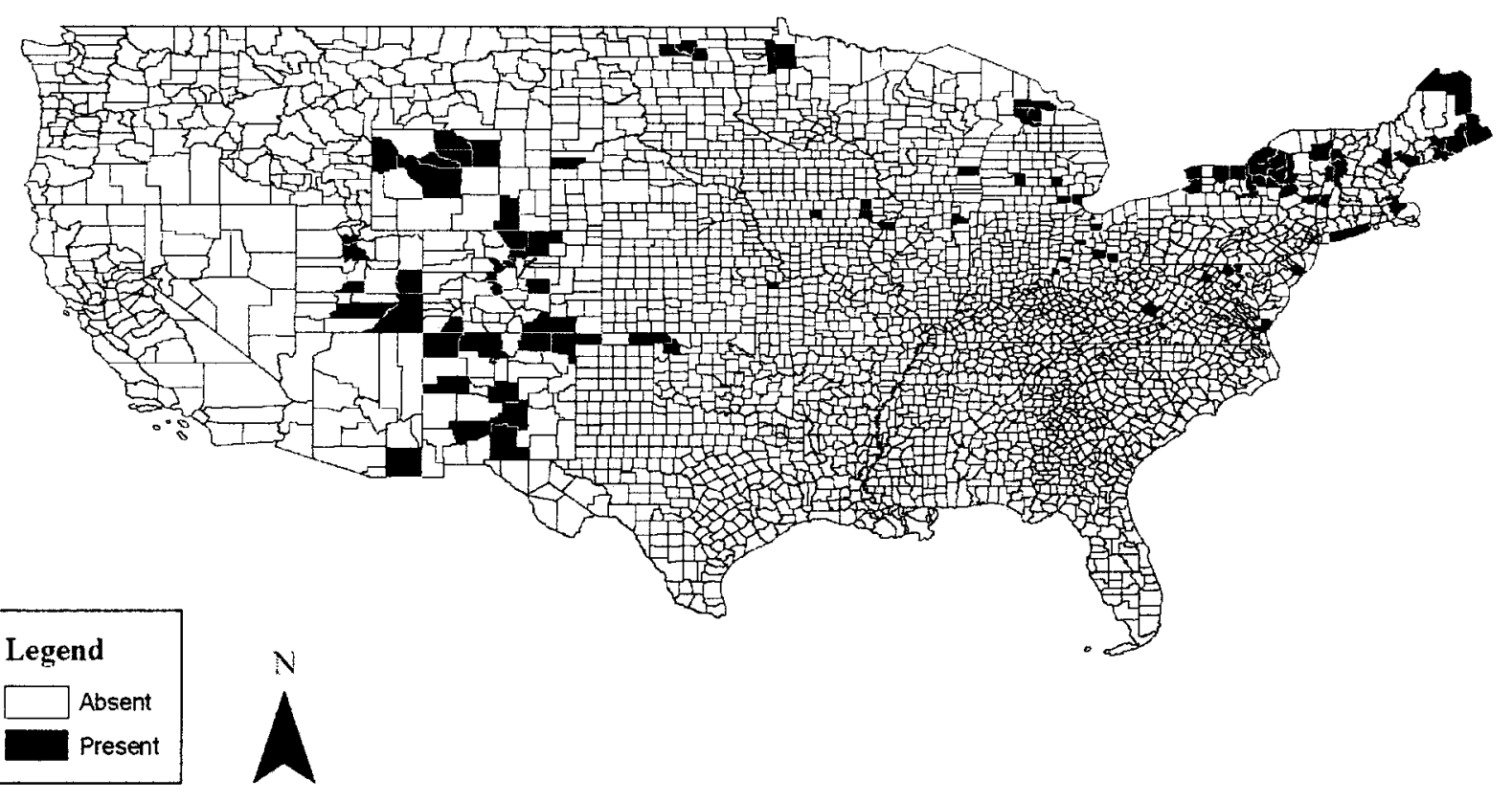




\section{BIOGEOGRAPHIC RANGE BY COUNTY IN THE CONTIGUOUS STATES}

Pupoides albilabris

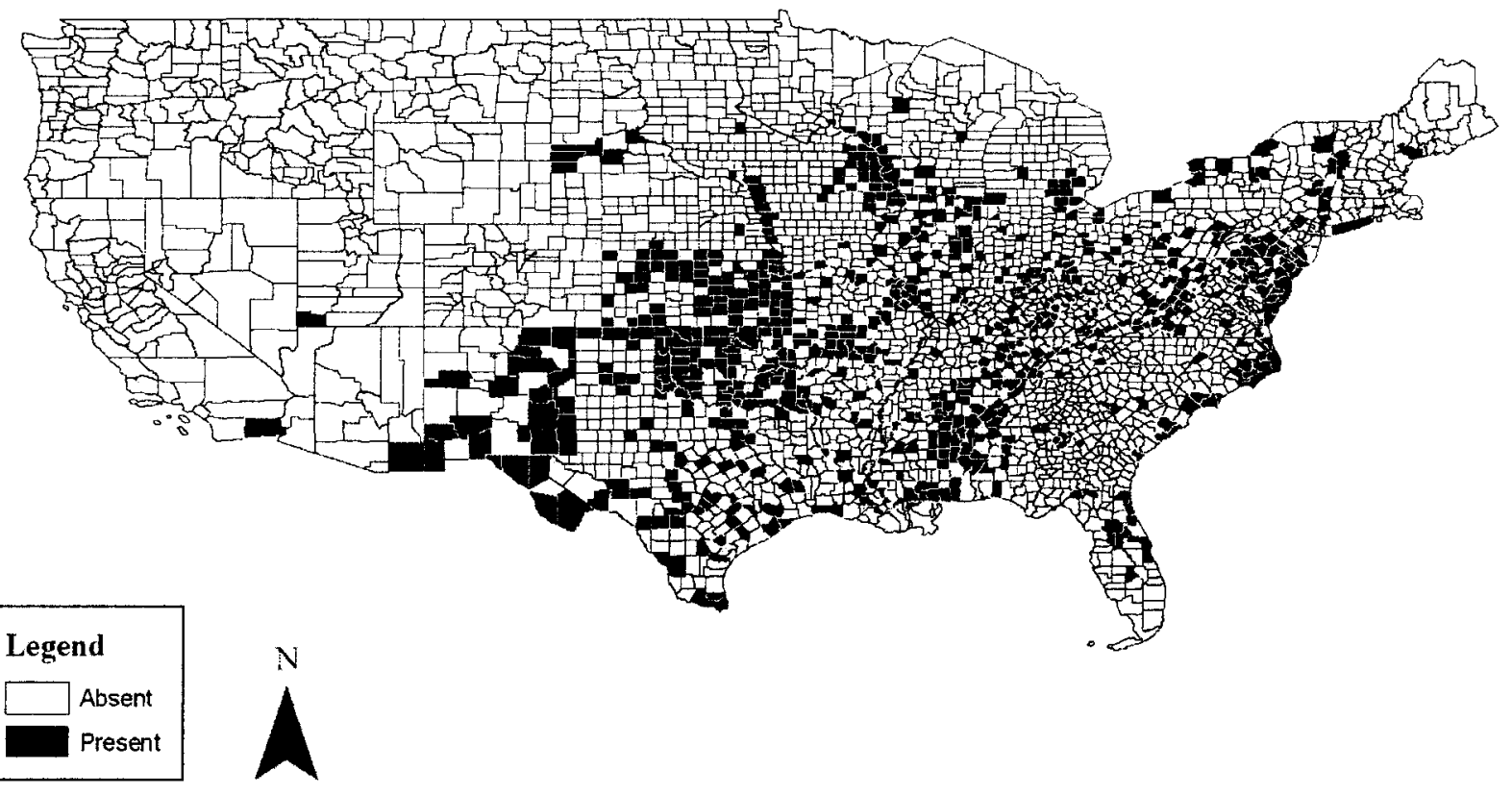




\section{BIOGEOGRAPHIC RANGE BY COUNTY IN THE CONTIGUOUS STATES}

Pupoides modicus

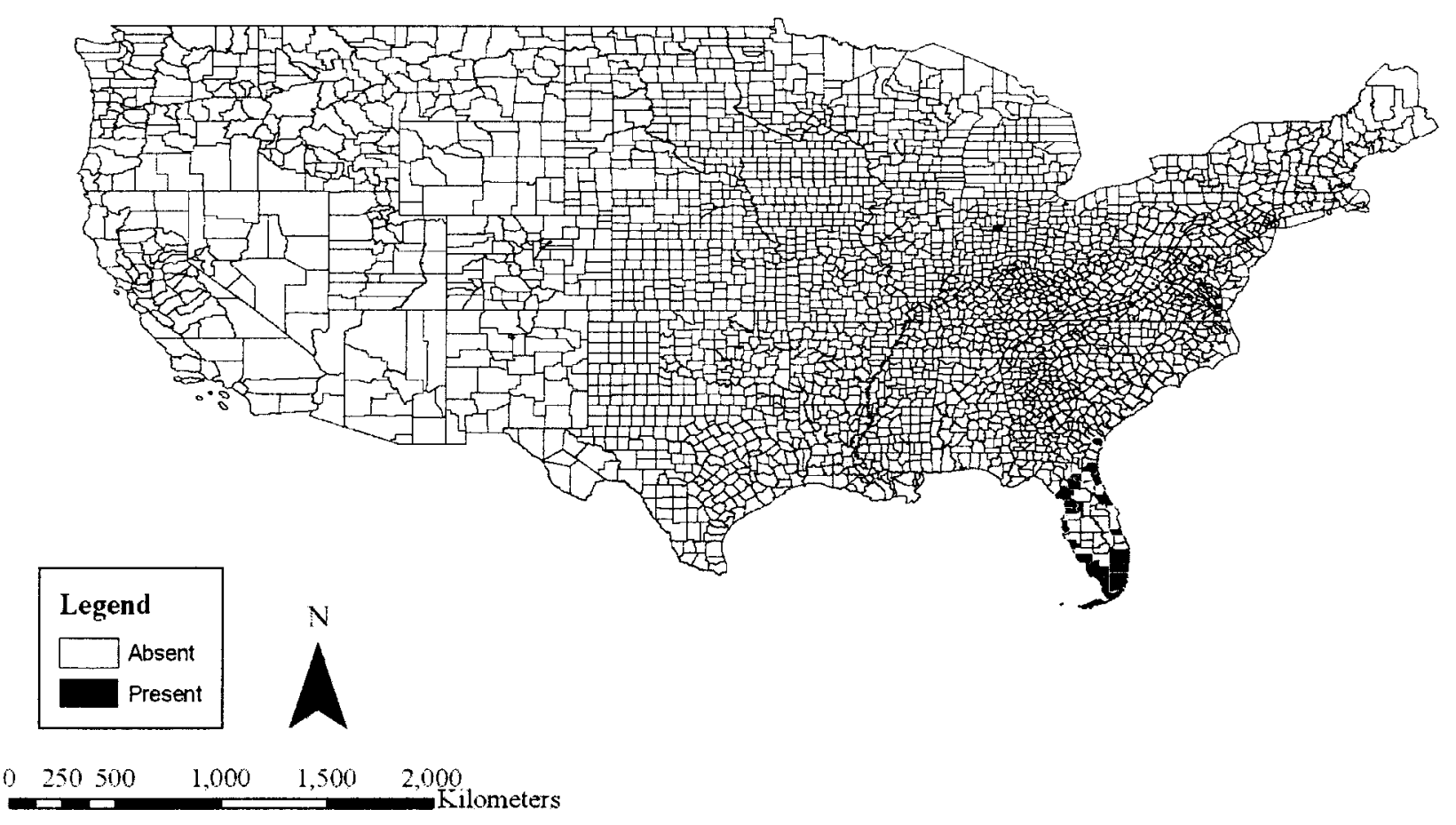


BIOGEOGRAPHIC RANGE BY COUNTY IN THE CONTIGUOUS STATES

Stagnicola elodes

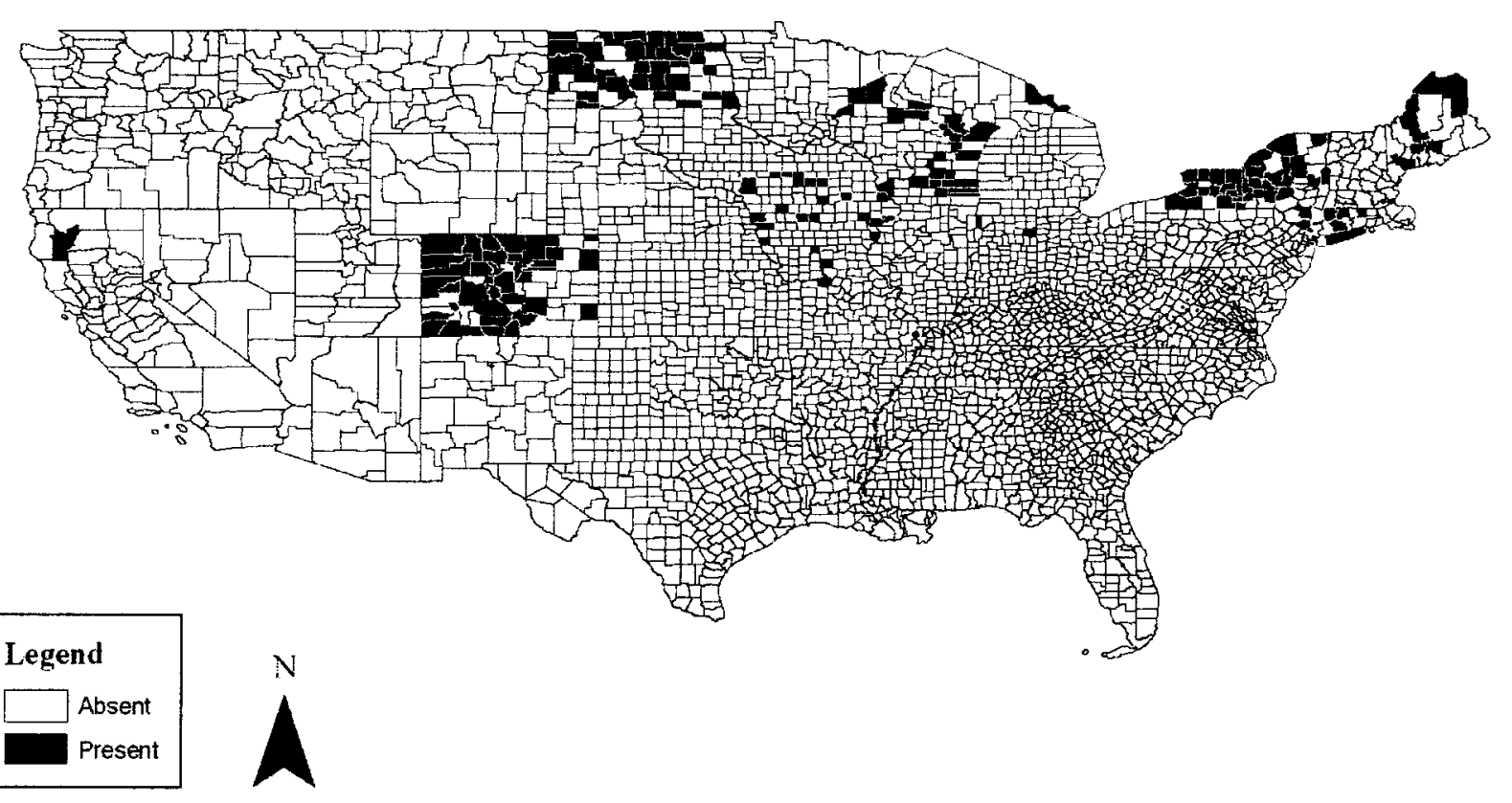

\begin{tabular}{llll}
0 & $250500 \quad 1,000 \quad 1,500 \quad 2,000$ \\
\hline
\end{tabular} 


\section{BIOGEOGRAPHIC RANGE BY COUNTY IN THE CONTIGUOUS STATES}

Stagnicola exilis

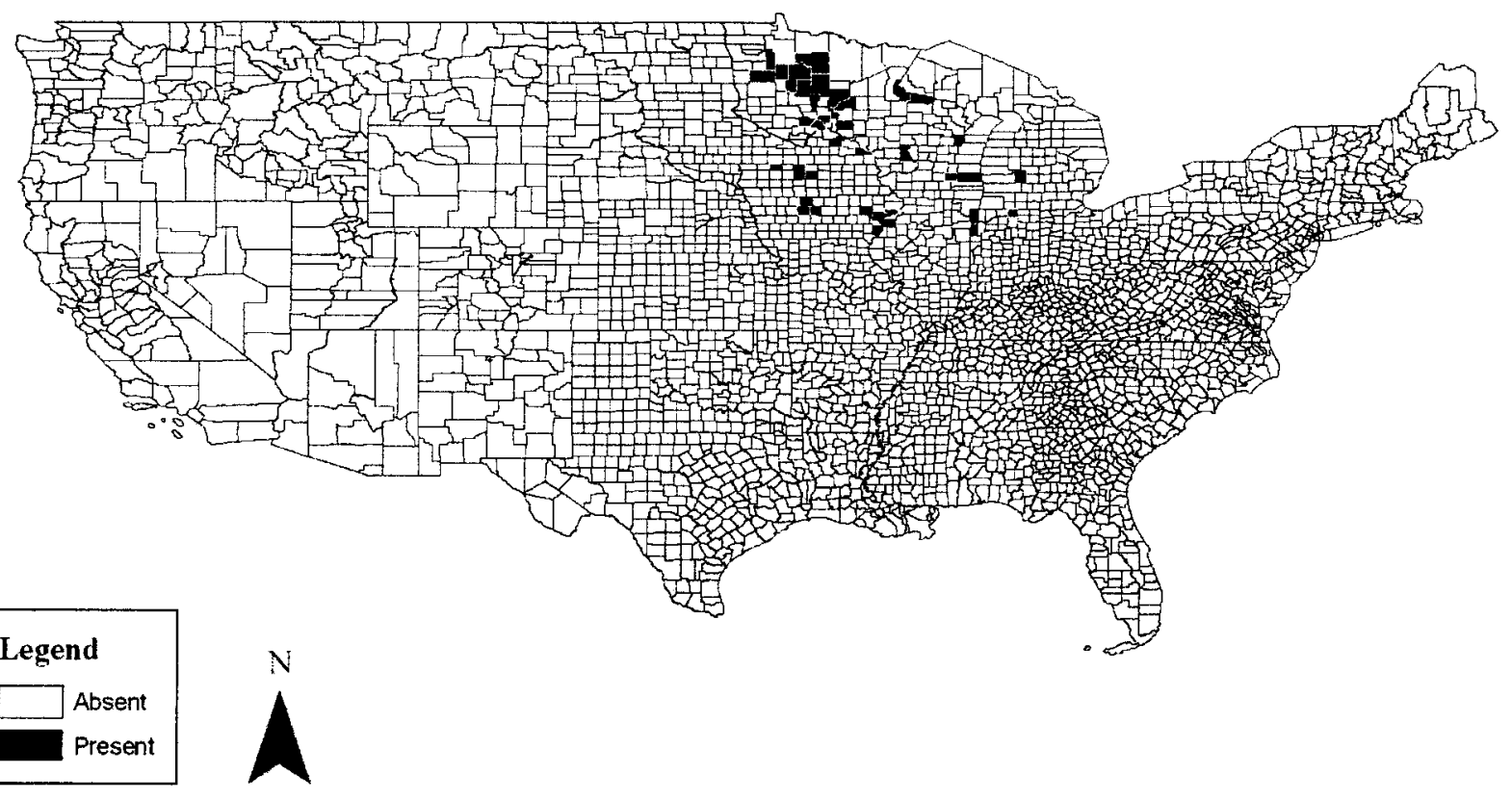

\begin{tabular}{llll}
$250500 \quad 1.000 \quad 1,500 \quad 2,000$ \\
\hline
\end{tabular} 

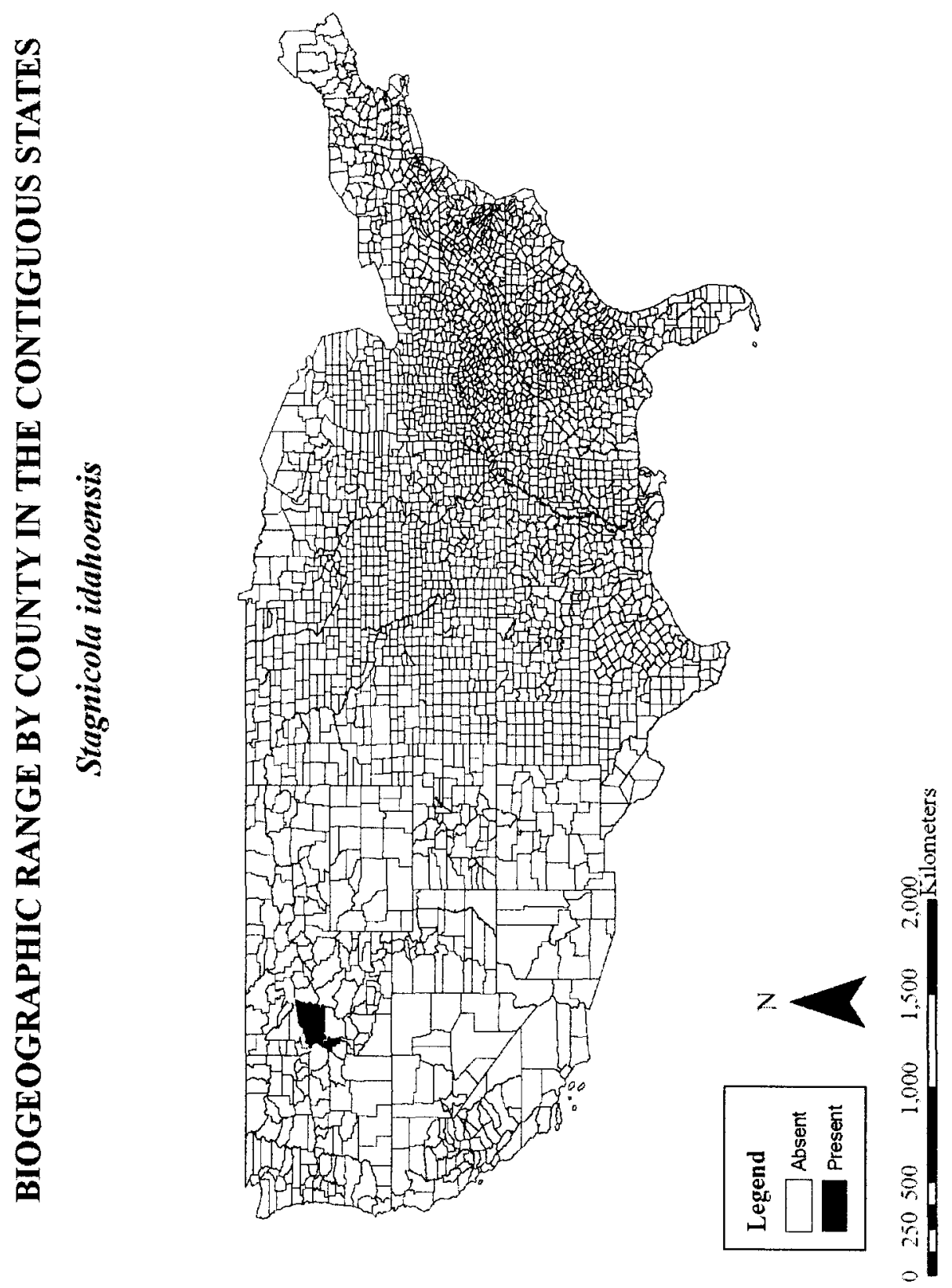
BIOGEOGRAPHIC RANGE BY COUNTY IN THE CONTIGUOUS STATES

Strobilops labyrinthicus

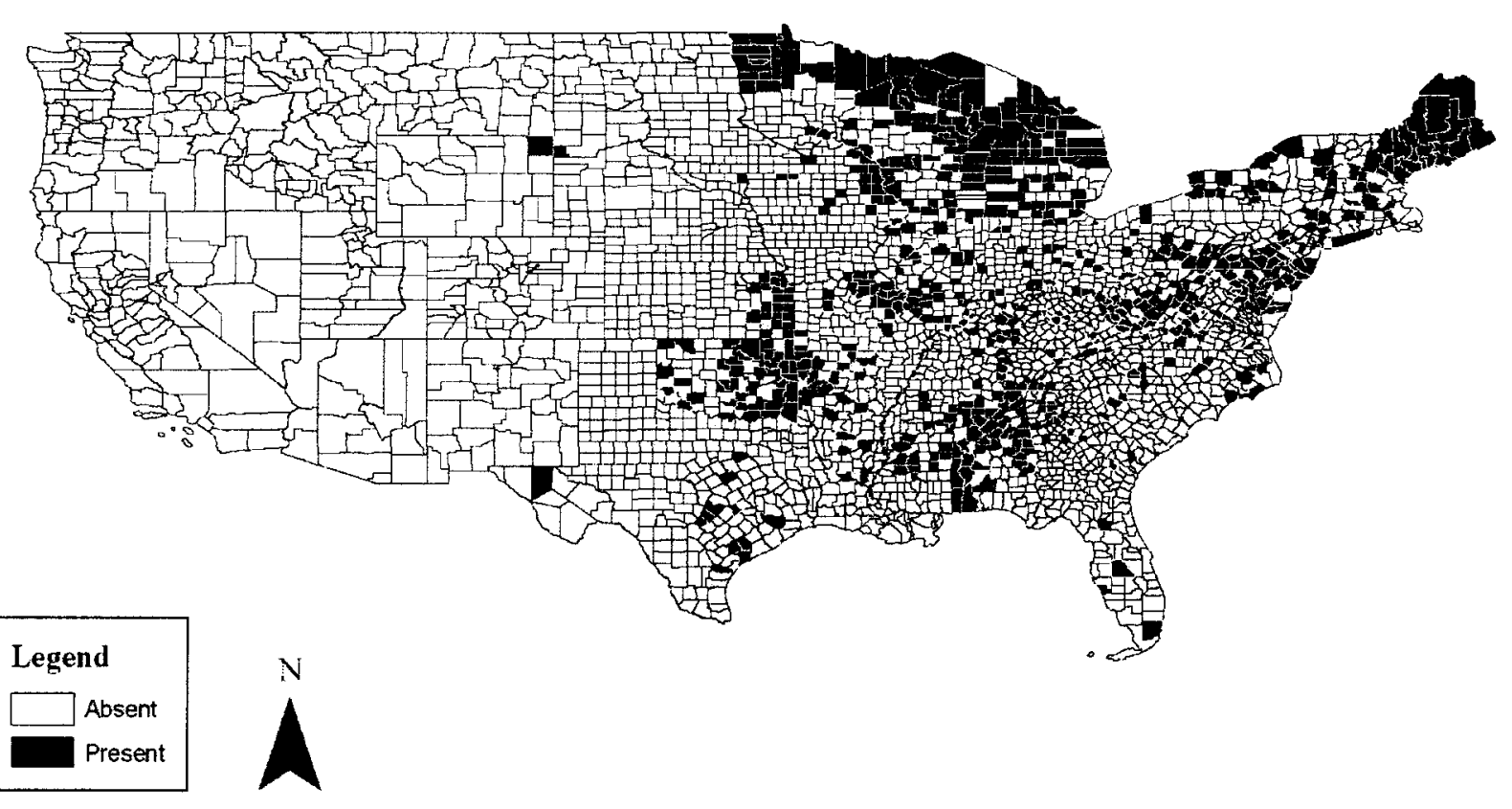

\begin{tabular}{llll}
0 & $250500 \quad 1,000 \quad 1,500 \quad 2,000$ \\
\hline
\end{tabular} 
BIOGEOGRAPHIC RANGE BY COUNTY IN THE CONTIGUOUS STATES

Succineidae

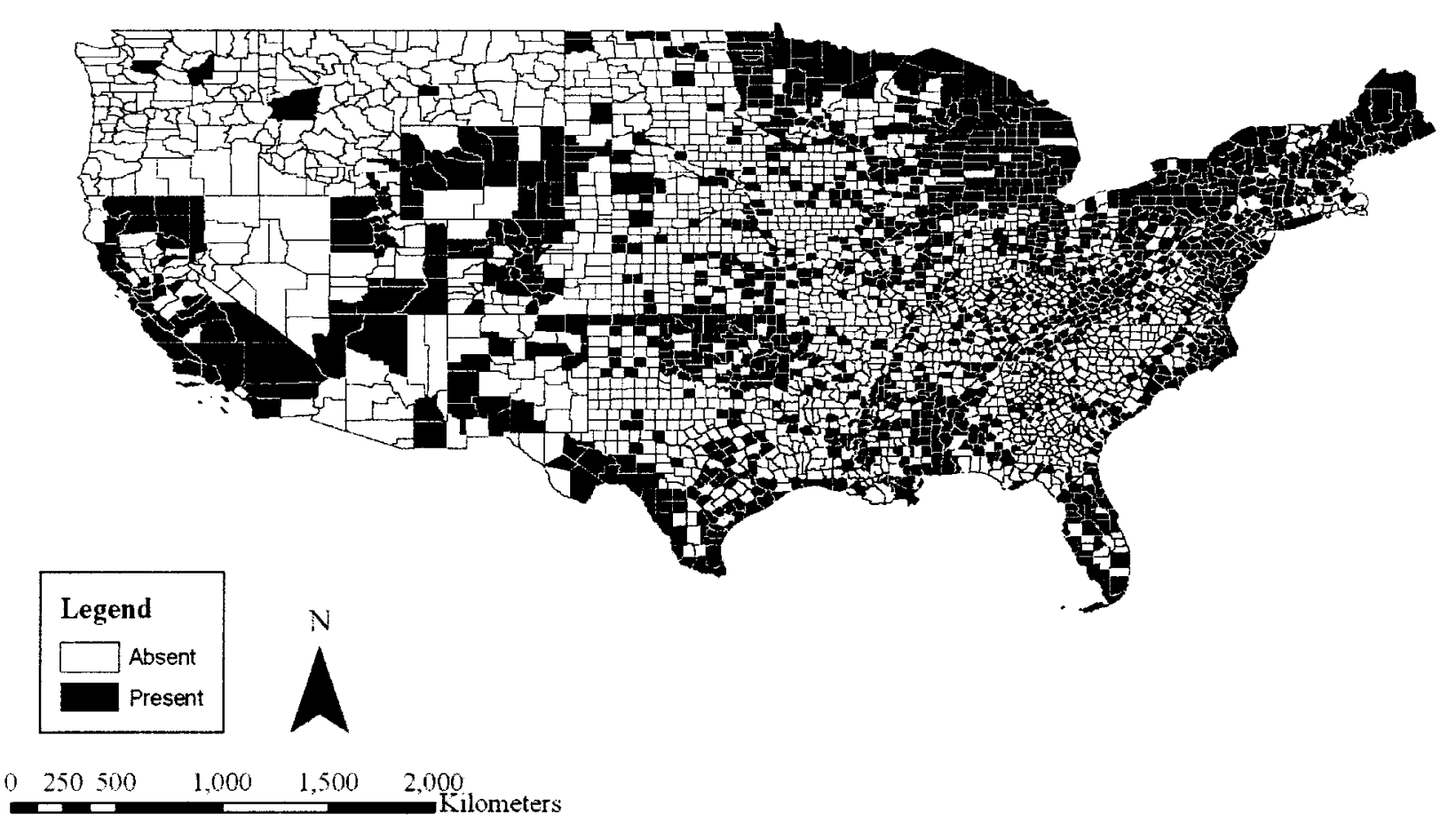




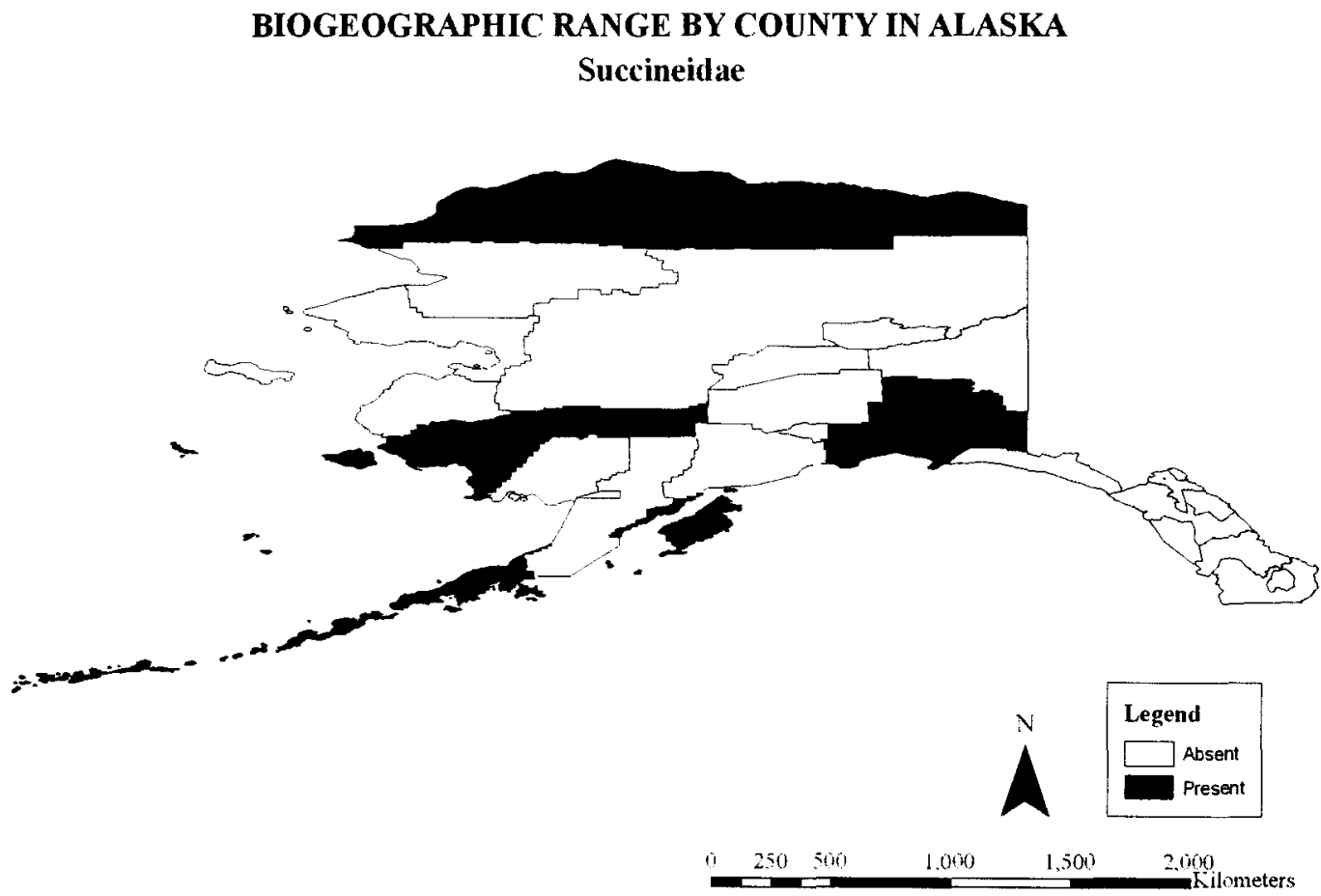

BIOGEOGRAPHIC RANGE BY COUNTY IN HAWAII

Succineidae
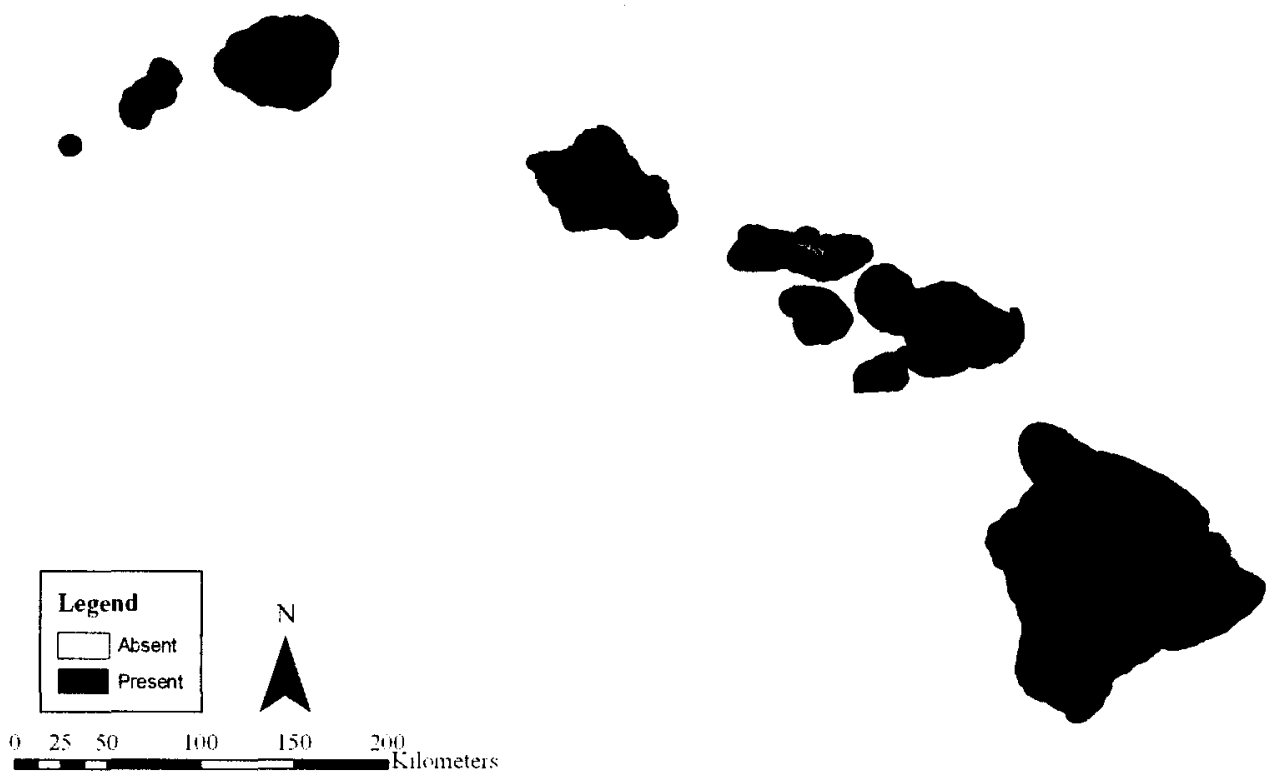


\section{BIOGEOGRAPHIC RANGE BY COUNTY IN THE CONTIGUOUS STATES}

Vallonia cyclophorella

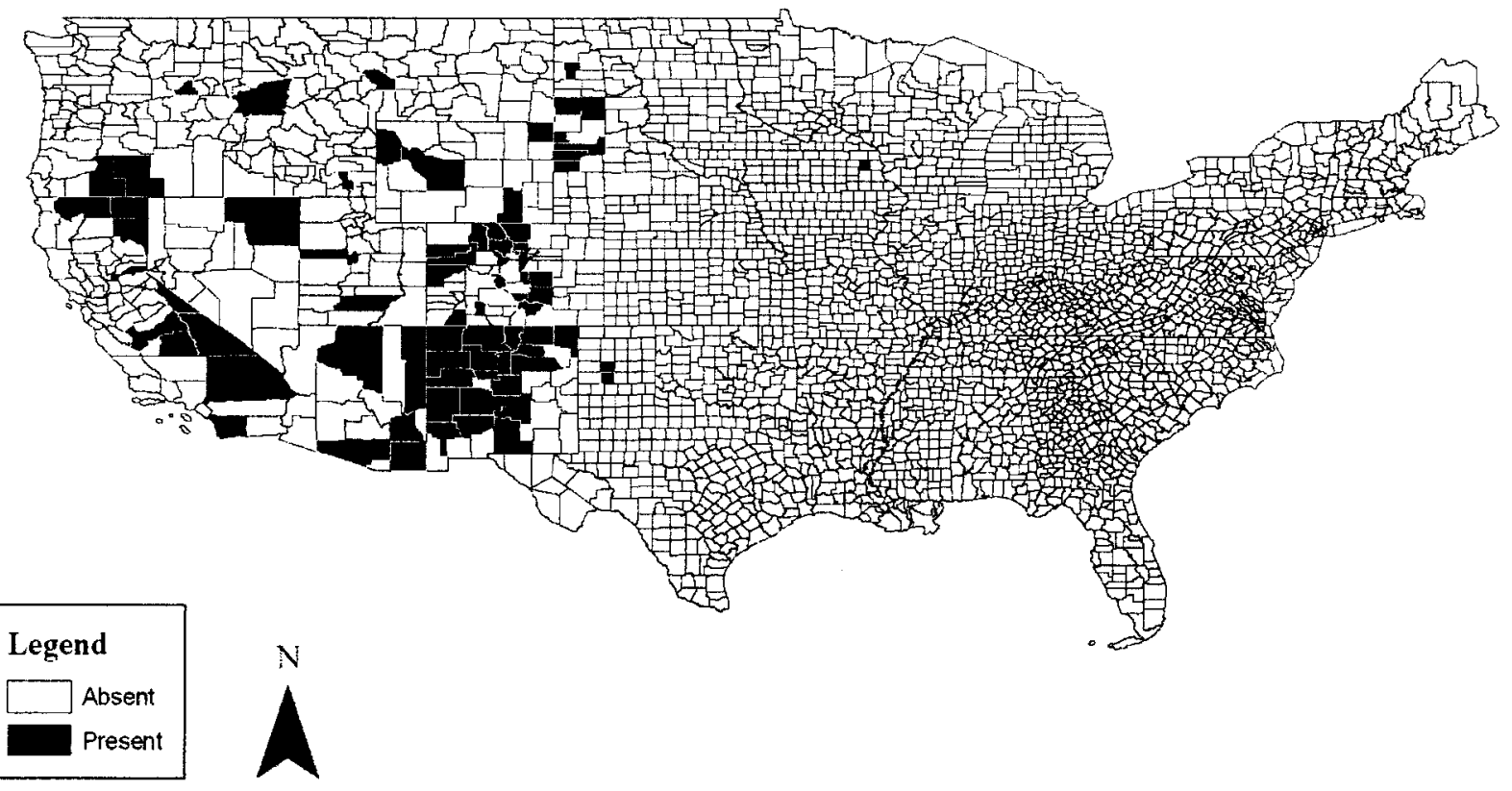

\begin{tabular}{llll}
250500 & $1,000 \quad 1,500 \quad 2,000$ \\
\hline
\end{tabular} 

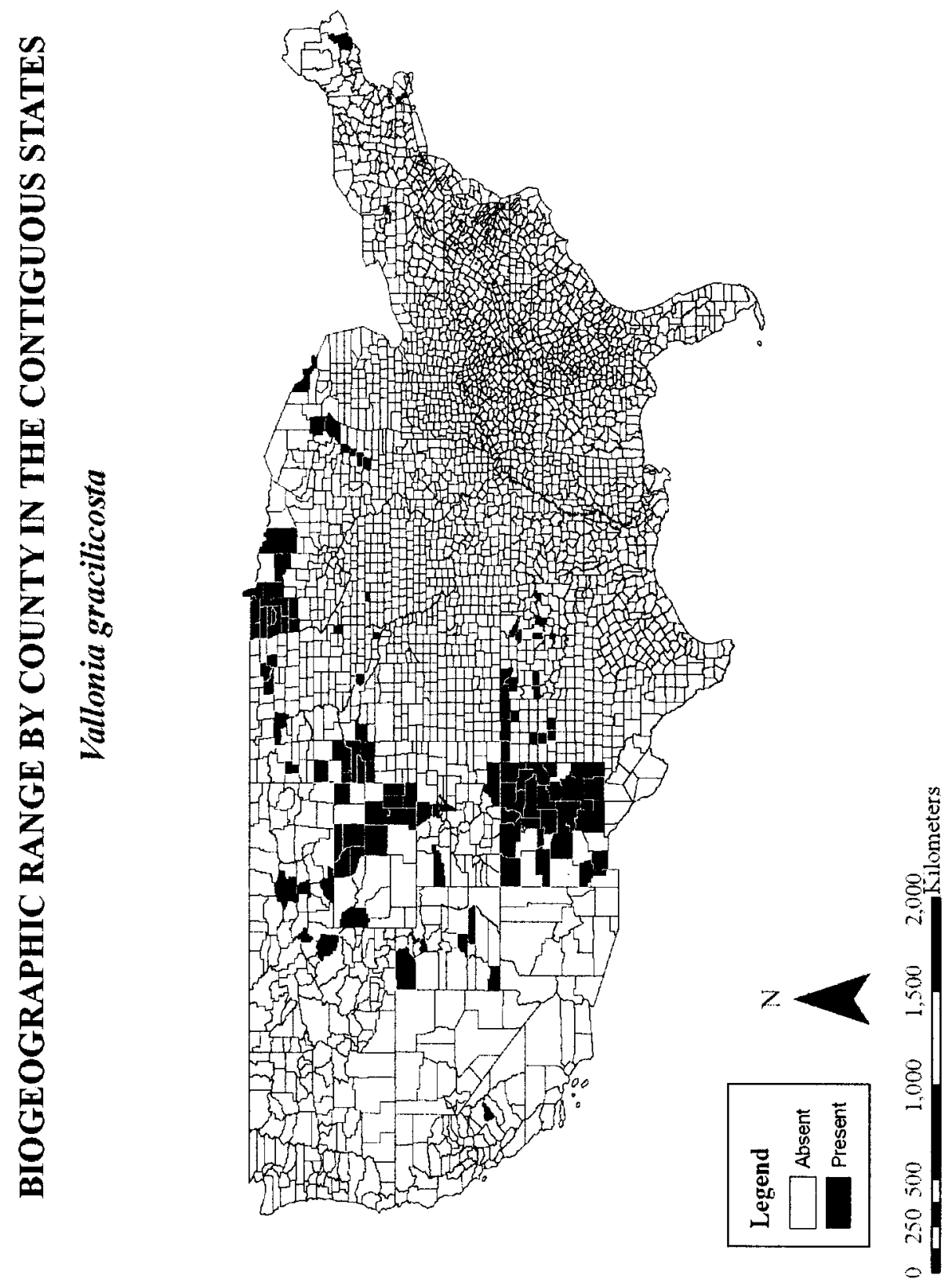


\section{BIOGEOGRAPHIC RANGE BY COUNTY IN THE CONTIGUOUS STATES}

Vallonia parvula

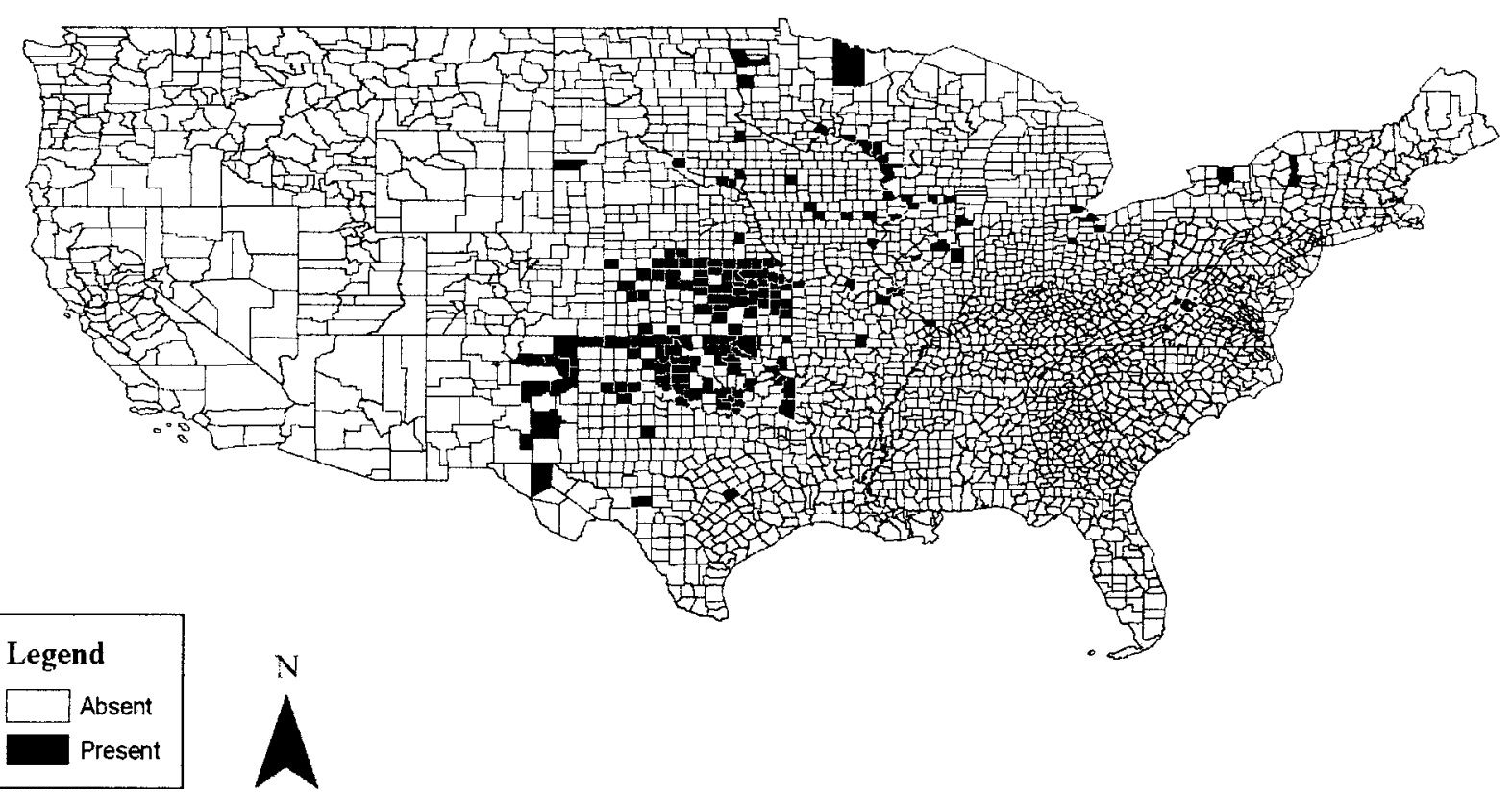

$0 \quad$\begin{tabular}{llll}
$250500 \quad 1,000 \quad 1,500 \quad 2,000$ \\
\hline
\end{tabular} 


\section{BIOGEOGRAPHIC RANGE BY COUNTY IN THE CONTIGUOUS STATES}

Vallonia perspectiva

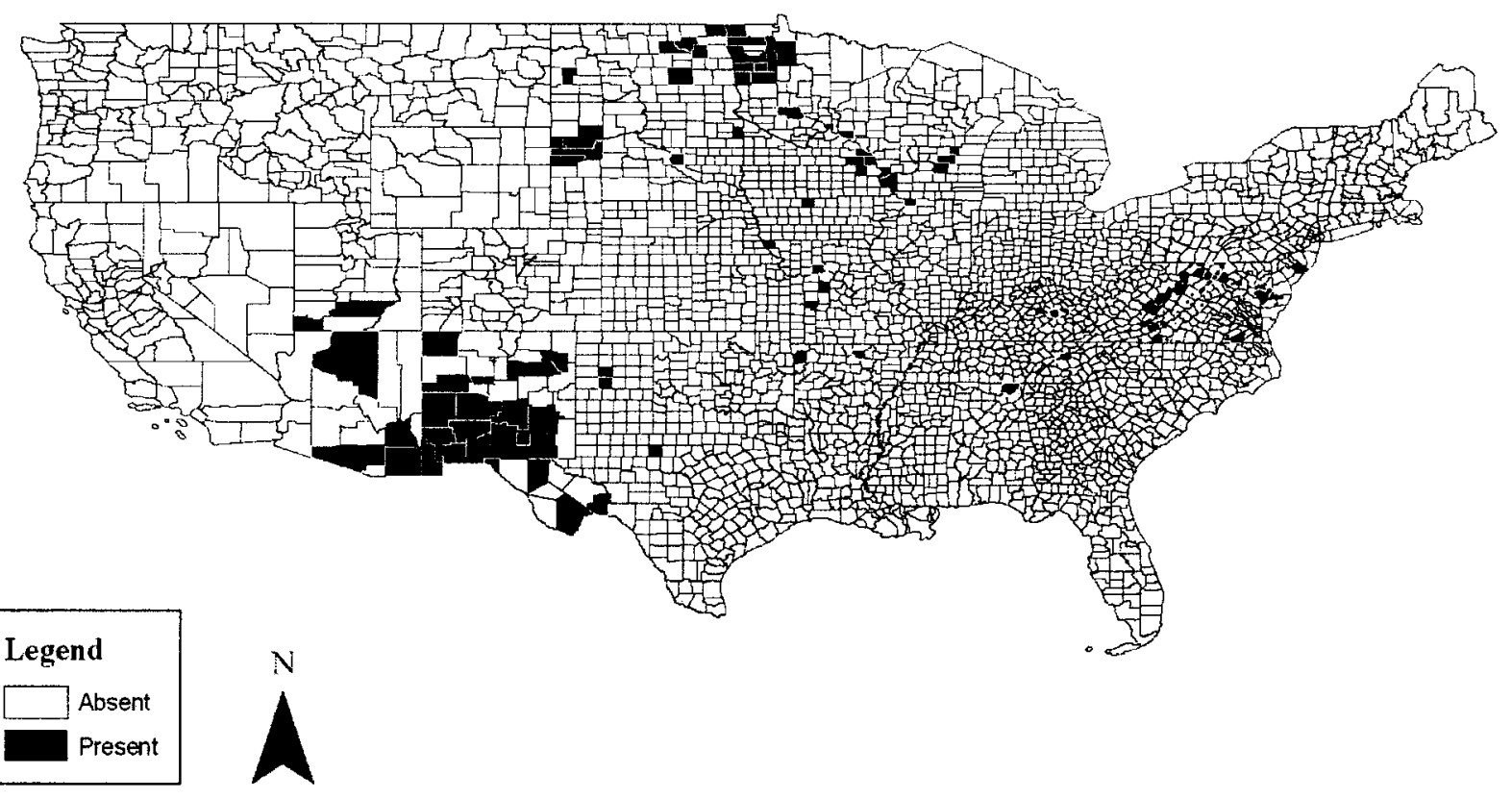

\begin{tabular}{llll}
$250500 \quad 1,000 \quad 1,500 \quad 2,000$ \\
\hline
\end{tabular} 


\section{BIOGEOGRAPHIC RANGE BY COUNTY IN THE CONTIGUOUS STATES}

Vallonia pulchella

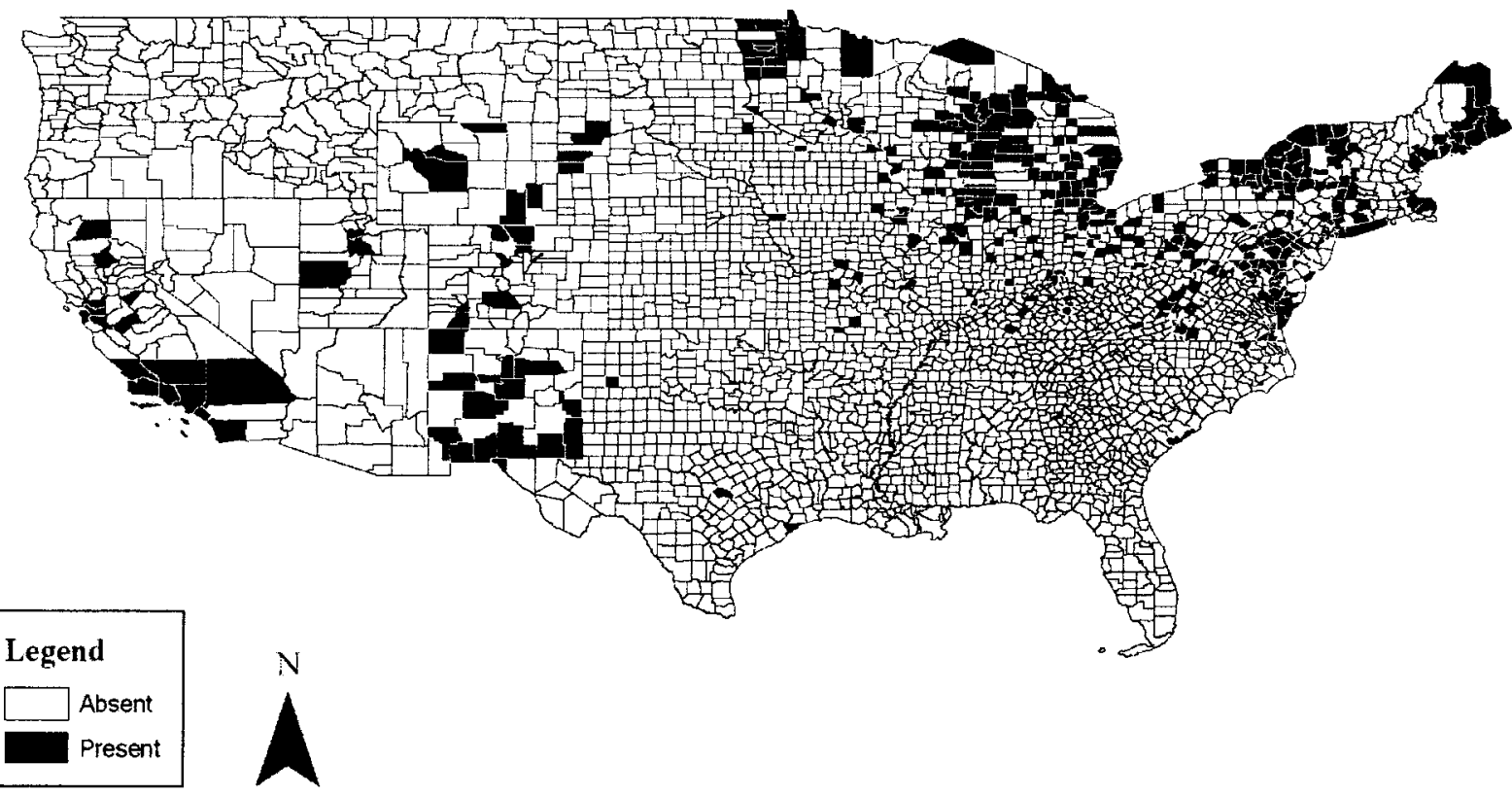

\begin{tabular}{llll}
$250 \quad 500$ & 1.000 & 1,500 & 2,000 \\
\hline
\end{tabular} 


\section{BIOGEOGRAPHIC RANGE BY COUNTY IN THE CONTIGUOUS STATES}

Valvata tricarinata

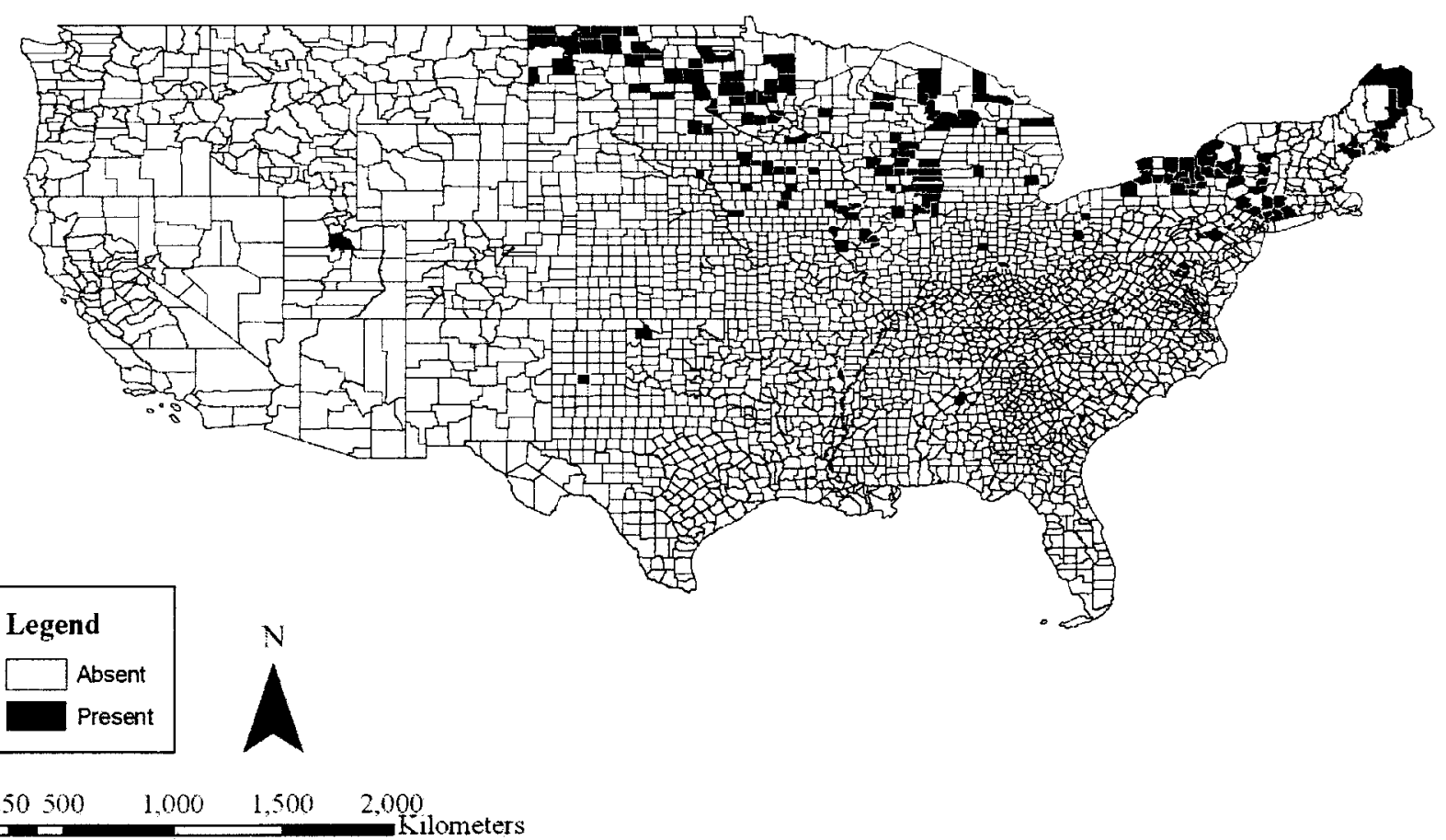




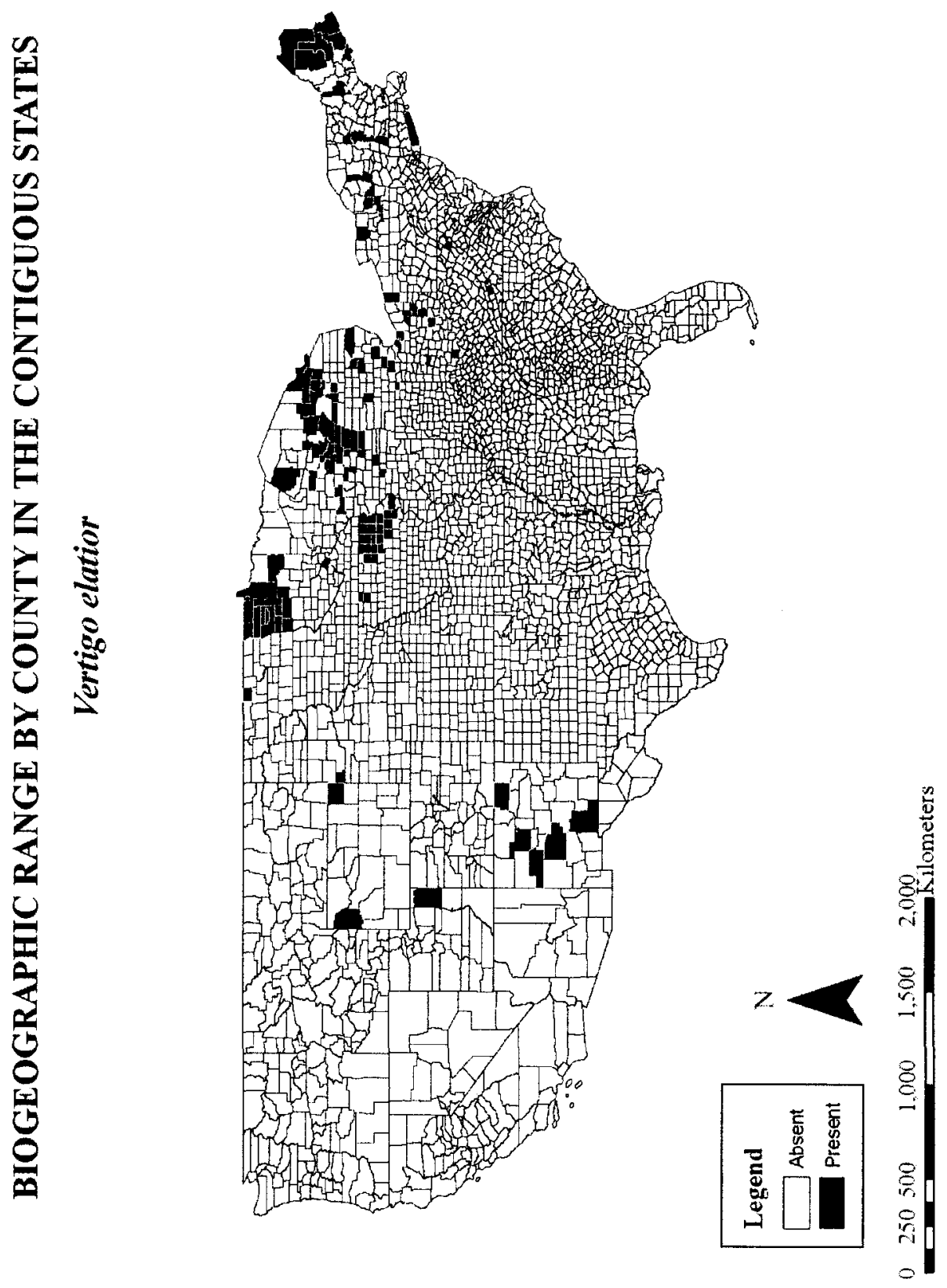



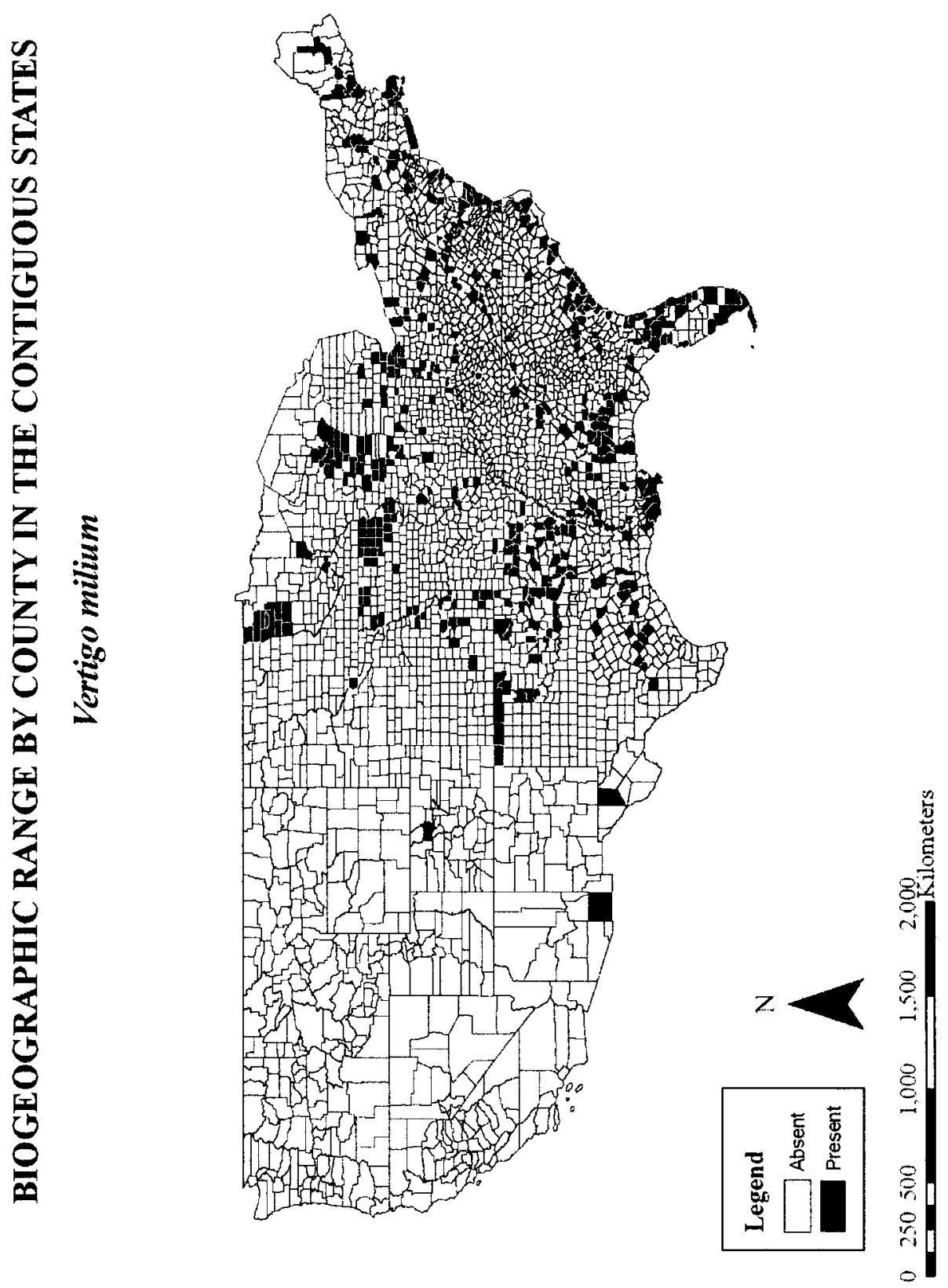
BIOGEOGRAPHIC RANGE BY COUNTY IN THE CONTIGUOUS STATES

Vertigo ovata

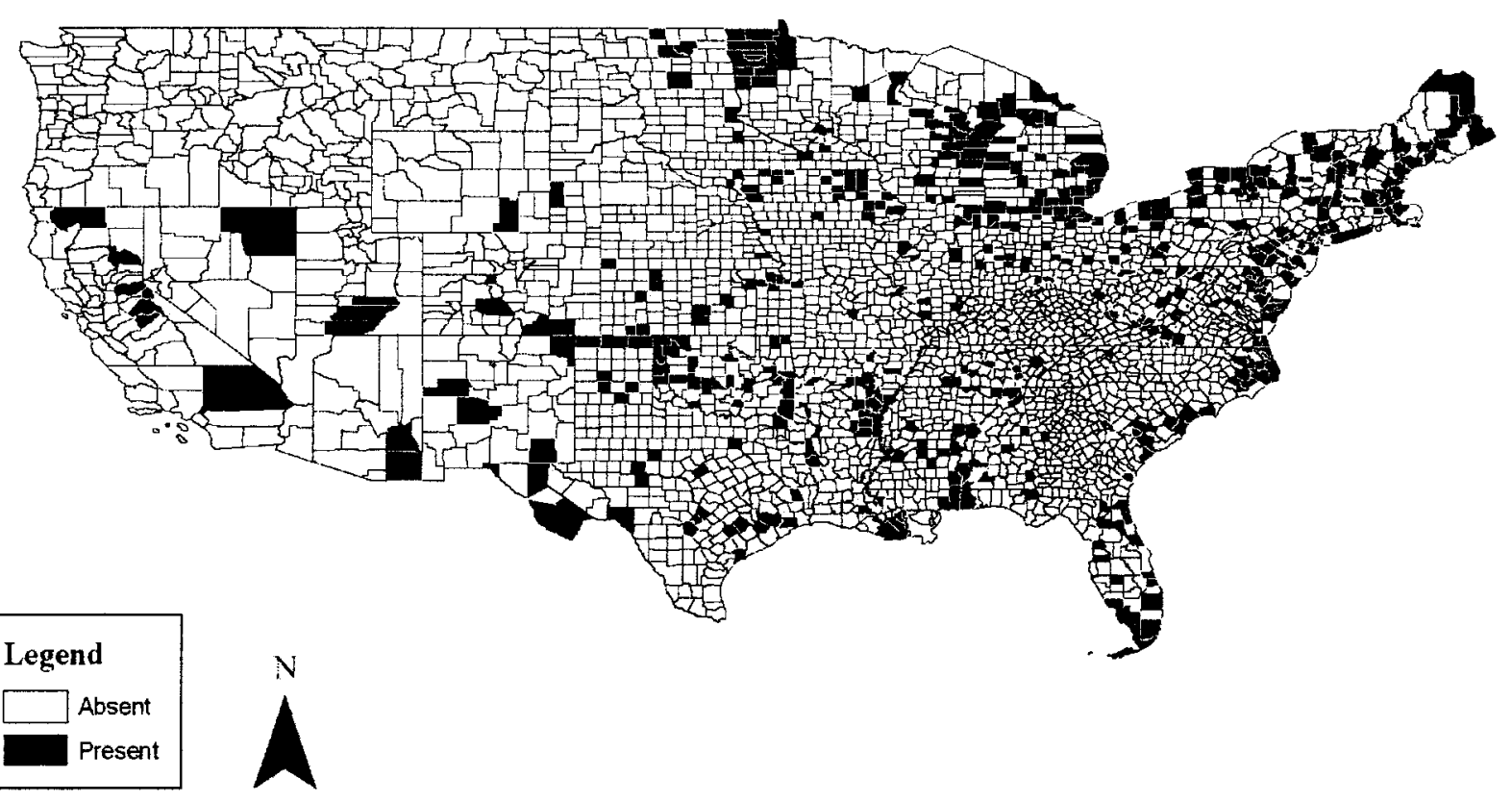

$0 \quad 250500 \quad 1,000 \quad 1,500 \quad 2,000$ Kilometers 
BIOGEOGRAPHIC RANGE BY COUNTY IN ALASKA

Vertigo ovata

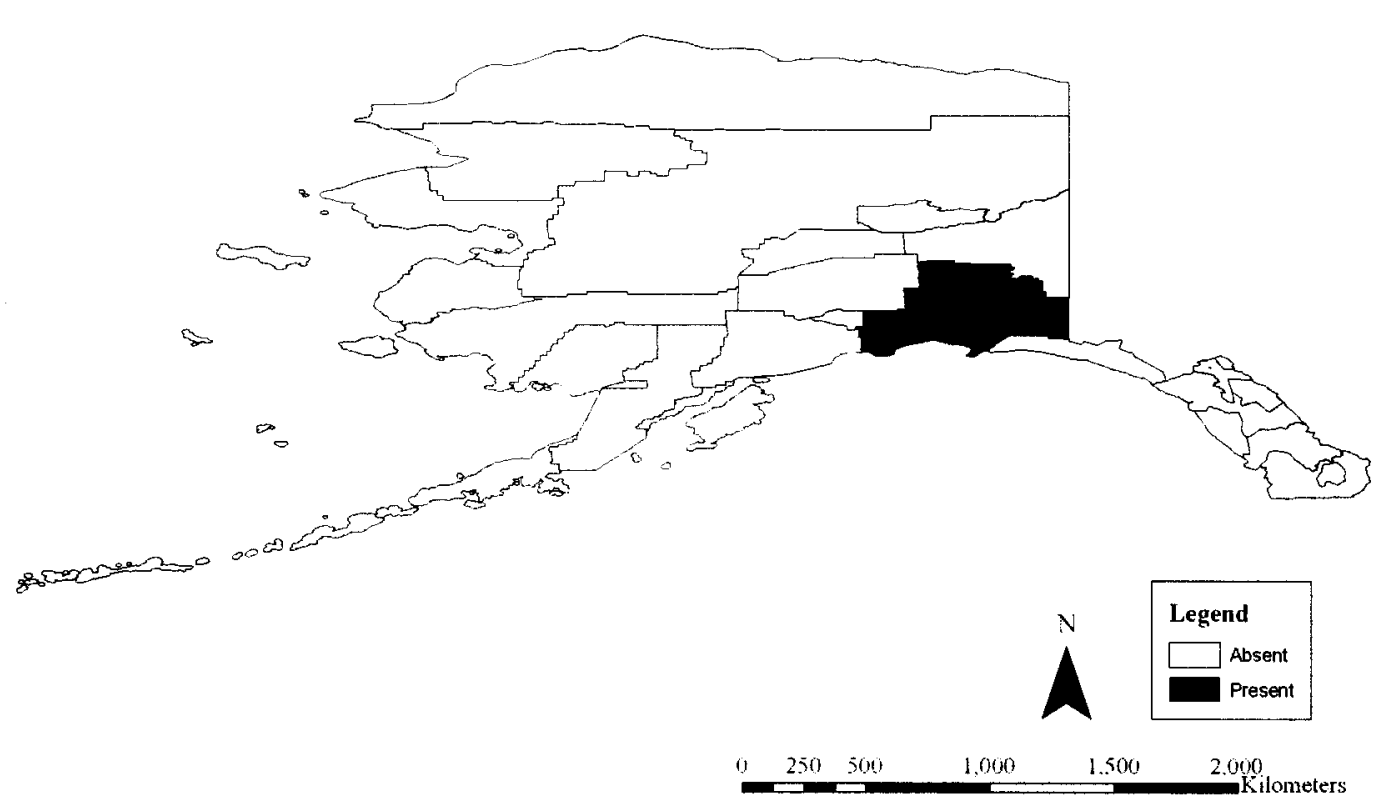




\section{BIOGEOGRAPHIC RANGE BY COUNTY IN THE CONTIGUOUS STATES}

Vertigo rugosula

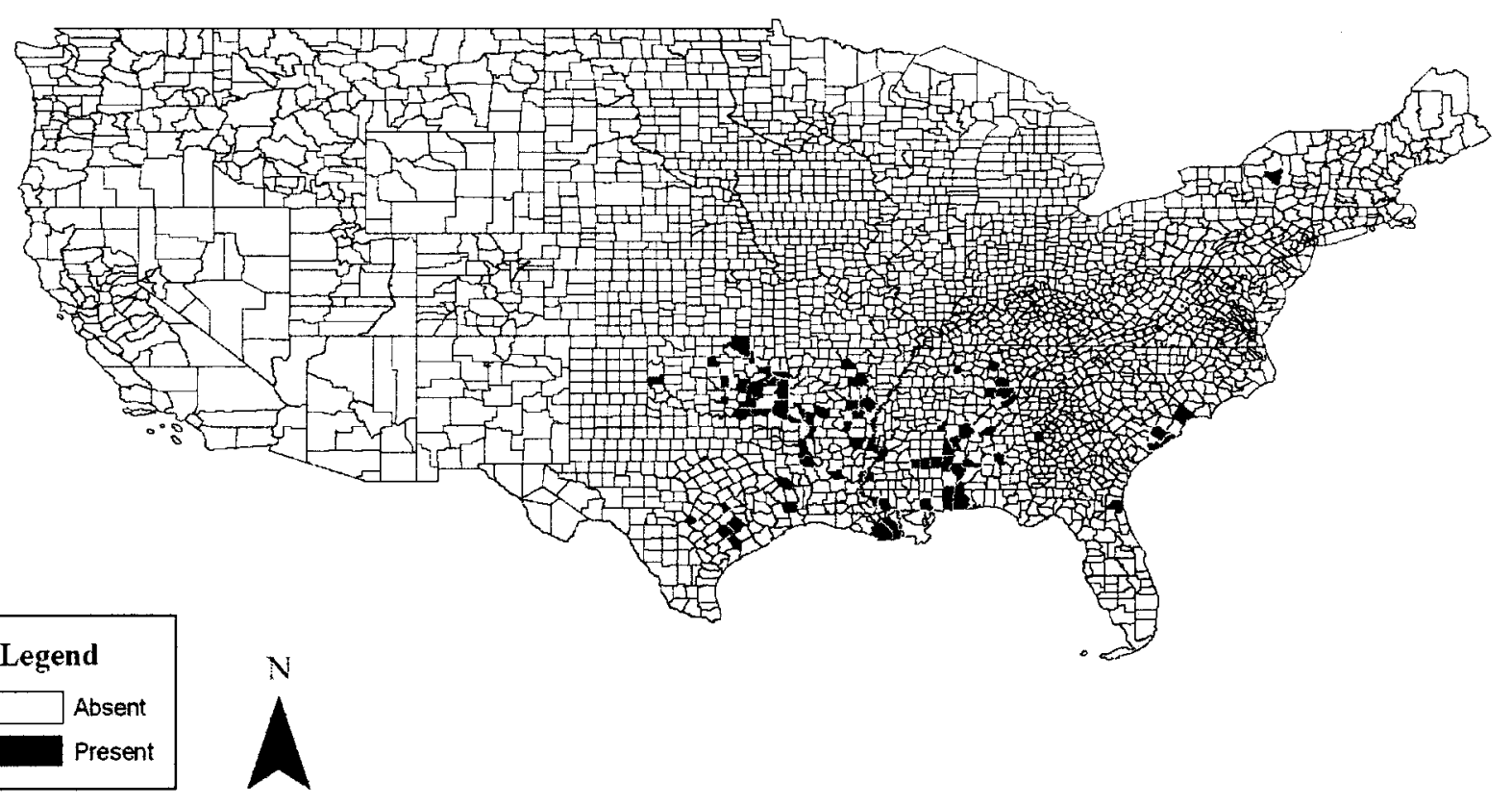


BIOGEOGRAPHIC RANGE BY COUNTY IN THE CONTIGUOUS STATES

Zonitoides arboreus

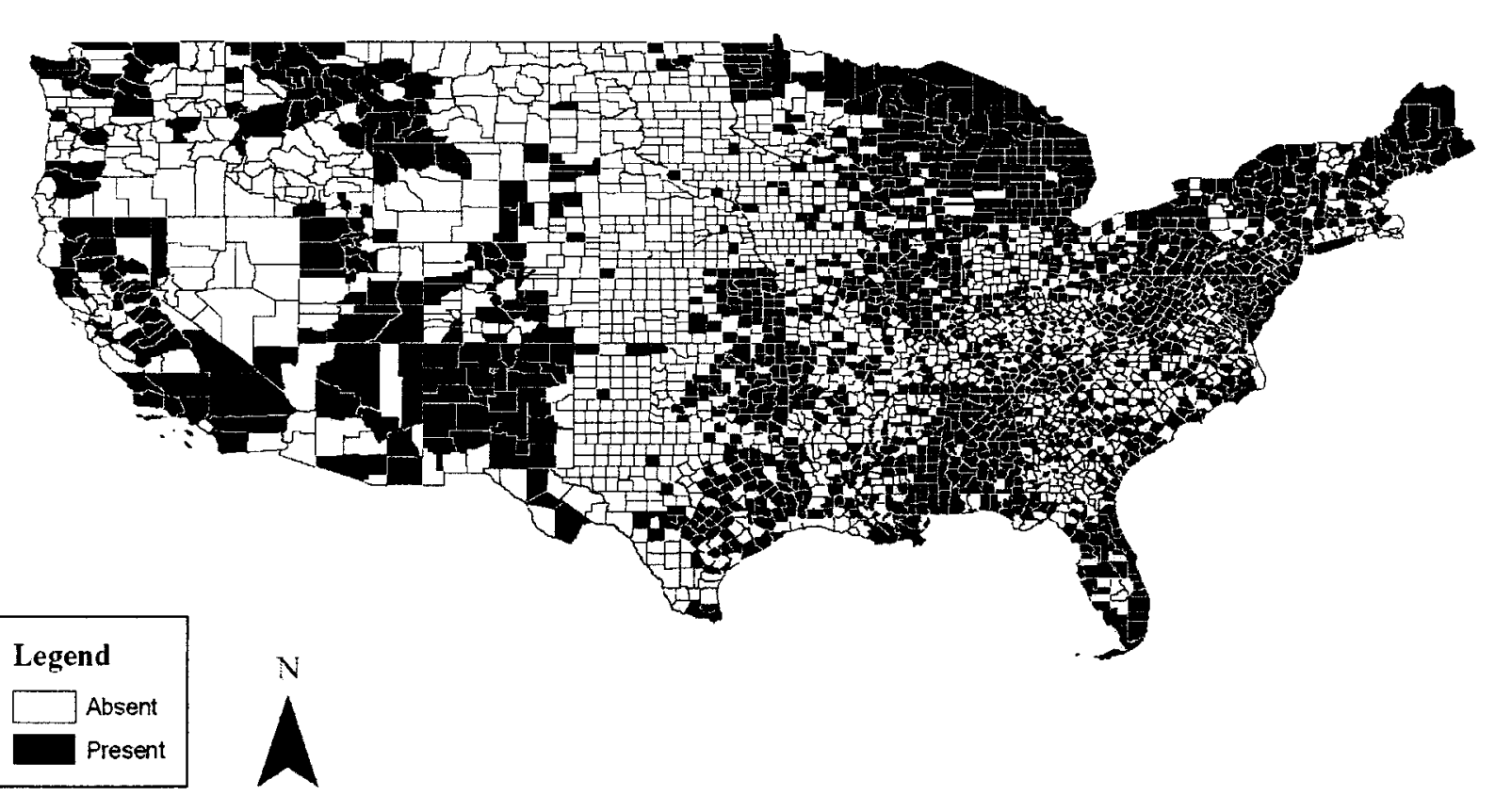

$0 \quad 250500 \quad 1,000 \quad 1,500 \quad 2,000$ Kilometers 
BIOGEOGRAPHIC RANGE BY COUNTY IN HAWAII Zonitoides arhoreus
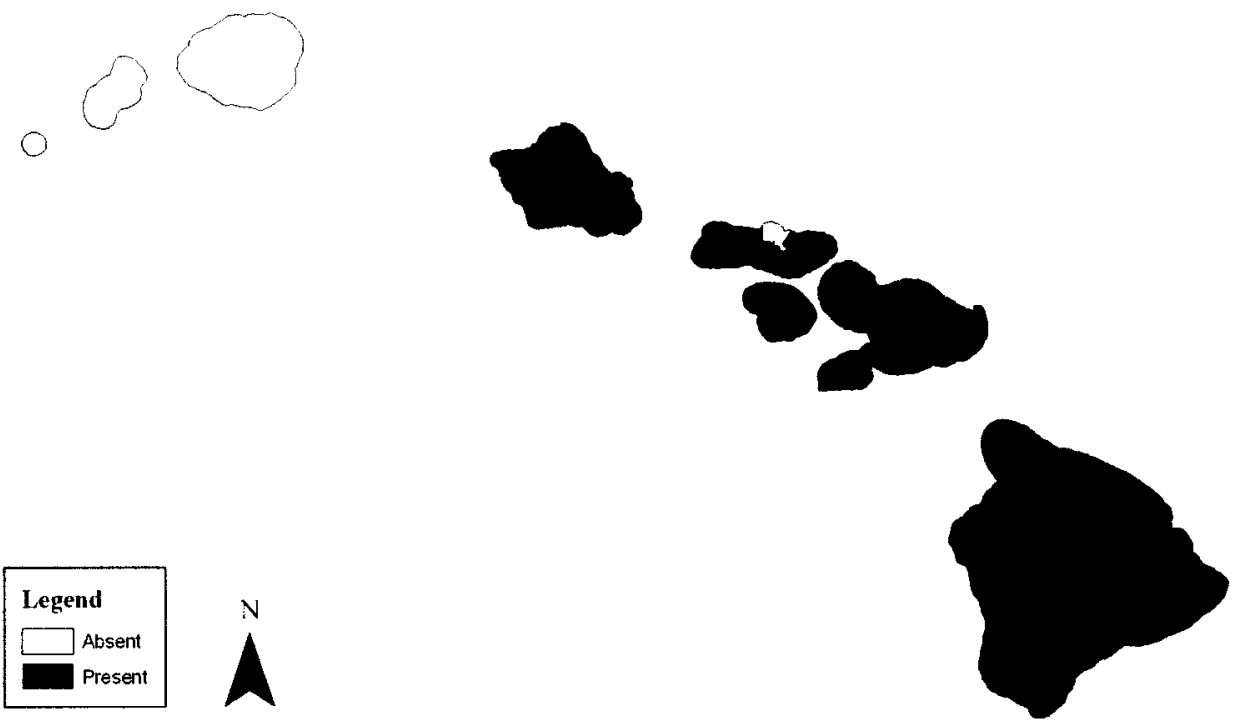

195 


\section{CURRICULUM VITAE}

\section{Name}

Brian W. Steffen

\section{Address}

7403 Beechview Way

Apartment 3

Louisville, KY 40219

(502) 333-4652

bwstef01@gwise.louisville.edu

\section{Date of Birth}

Milwaukee, Wisconsin-March 10, 1975

\section{Education}

University of Louisville (Louisville, KY): Ph. D., 2010 Department of Biology

Fort Hays State University (Hays, KS): M. S., 2002 Department of Geosciences

University of Wisconsin-Milwaukee (Milwaukee, WI): B. S., 2000 Department of Geosciences (major) Department of Biological Sciences (minor)

\section{Teaching Experience}

West Kentucky Community and Technical College (Paducah, KY): Adjunct Professor BIO 143 Zoology with Laboratory: Spring 2008

GLY 111 Physical Geology Laboratory: Fall 2007 GLY 101 Physical Geology: Fall 2007

Murray State University (Murray, KY): Teaching Assistant

BIO 330 Principles of Ecology Laboratory: Fall 2006

BIO 221 Zoology: Animal Form and Function Laboratory: Spring 2006

BIO 116 Biological Inquiry and Analysis Laboratory: Fall 2006

BIO 101 Biological Concepts Laboratory: Fall 2005; Spring 2006, 2007

University of Louisville: Teaching Assistant BIOL 244 Principles of Biology Laboratory: Spring 2005, 2009, 2010; Summer 2009, 2010; Fall 2008, 2009

BIOL 104 An Introduction to Biological Systems Laboratory: Fall 2004

Fort Hays State University: Teaching Assistant

GSCI 202 Historical Geology Laboratory: Spring 2001, 2002

GSCI 102 Introduction to Geology Laboratory: Fall 2000, 2001

\section{Other Experiences}

- I received training in the use of a Philips 201 Transmission Electron Microscope (University of Louisville, 2005)

- Field Assistant: I helped collect and process late Cenozoic microfossils from southwest Kansas (Murray State University, 2004) 
- Volunteer Research Assistant: I examined acid-treated core samples for Devonian conodonts and helped give informal presentations to school tour groups (Milwaukee Public Museum, 1998)

\section{Awards Won}

Doctoral Dissertation Completion Award (2/23/10)

Clay Memorial Biology Scholarship Fund (4/23/09)

Talks

- Steffen, B. W., 2009, Molluscan paleocommunity analysis through time: University of Louisville, Graduate Student Honors and Awards Day.

- Steffen, B. W., and Alexander, J. E., Jr., 2008, Late Cenozoic molluscan paleoecology of southwestern Kansas: Kentucky Academy of Science, $94^{\text {th }}$ Annual Meeting, Lexington Kentucky, p. 23.

- Steffen, B. W., 2007, Plio-Pleistocene molluscan biodiversity of southwest Kansas: West Kentucky Community and Technical College.

\section{Poster Presentations}

- Steffen, B. W., and Alexander, J. E., Jr., 2010, Paleobiodiversity of molluscan assemblages from southwest Kansas: The Ecological Society of America, $95^{\text {th }}$ Annual Meeting, Pittsburgh, Pennsylvania, Official Meeting Program, p. 51.

- Steffen, B. W., 2009, Biodiversity through the ages-molluscan paleoecology of Kansas [abs.]: American Malacological Society, $75^{\text {th }}$ Annual Meeting, Ithaca, New York, Program and Abstracts, no. 37, p. 78.

\section{Additional Contribution}

Mayer, P. S., and Steffen, B. W., 1999, Faunal changes in tempestites and associated conodont faunas in the middle Devonian (Givetian) Milwaukee Formation, Milwaukee, Wisconsin [abs.]: Geological Society of America, $33^{\text {rd }}$ Annual Meeting, North-Central Section, Champaign, Illinois, Abstracts with Programs, v. 31, no. 5, p. A-58.

\section{Memberships}

The Ecological Society of America: 2010

American Malacological Society: 2005-present

The Paleontological Society: 2005-present

The Geological Society of America: 1999-present 